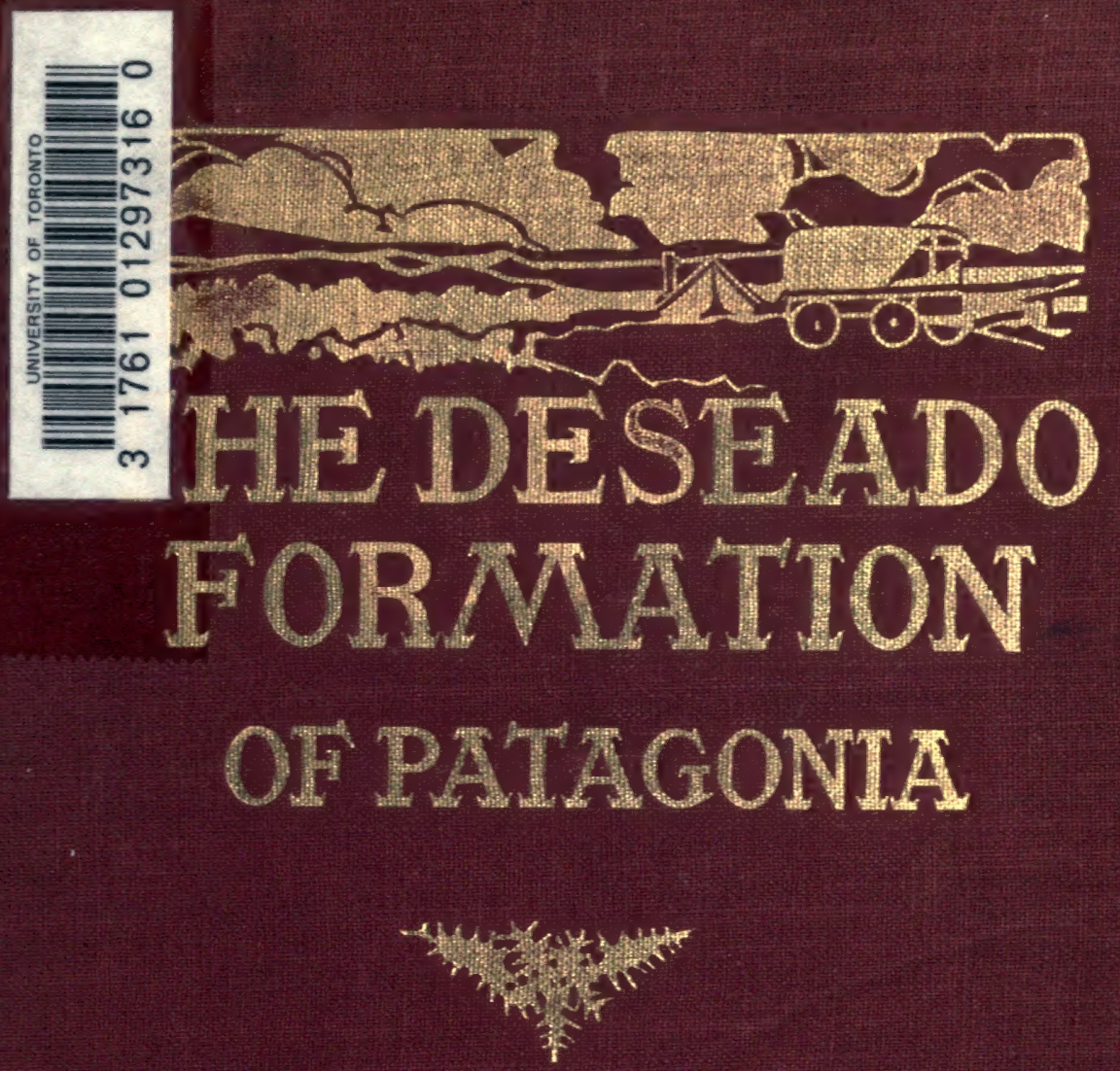

FREDERIC B. LOOMIS 


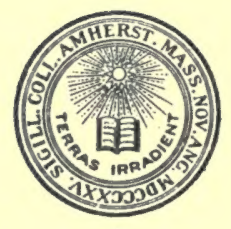

THIS BOOK IS PRESENTED WITH THE COMPLIMENTS OF THE TRUSTEES OF A M HERST COLLEGE

PLEASE ACKNOWLEDGE TO LIBRARIAN, AMHERST COLLEGE AMHERST, MASS. 
$(1)^{4 x}$ 



THE DESEADO FORMATION OF PATAGONIA 

Digitized by the Internet Archive in 2008 with funding from Microsoft Corporation 


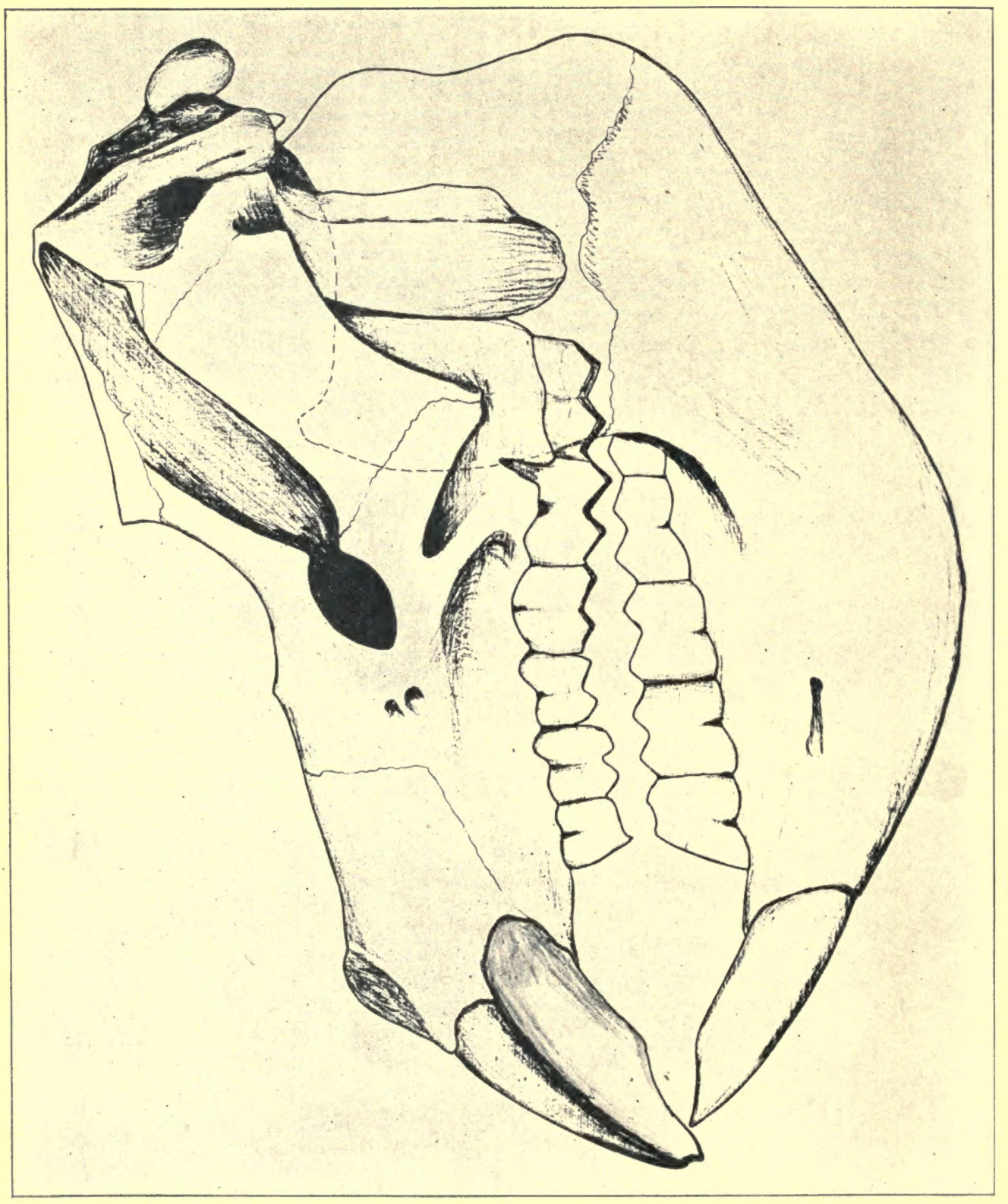

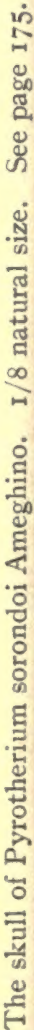




\section{The Deseado Formation}

\section{of Patagonia}

Frederic Brewster Loomis, Ph.D.

Professor of Comparative Anatomy

Amherst College

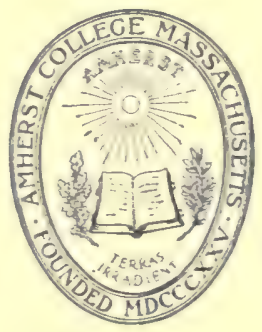

EIGHTH AMHERST EXPEDITION 1911

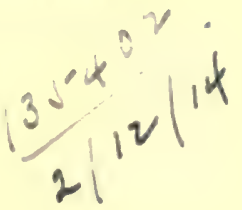

PLBLISHED UNDER THE AUSPICES OF THE TRUSTEES OF AMHERST COLLEGE 1914 


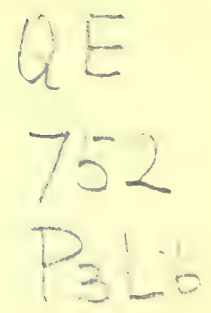

Copyright, IOI 4

BY FREDERIC B. LOOMIS

THE RUMFORD PRESS

CONCORD. N H H 


\section{CONTENTS}

CHAPTER

PAGE

1. Organization of the expedition-history of the work done in the Desearlo formation

II. Lescription of the Amherst locality-age of the overlying hedsage of underlying beds-age of Deseado . . . . . . . . . . . .

III. Table of the animals-stury of the feeding habits-character of the habitat-the origin of the elements of the Deseado fauna

IV. Systematic arrangement-the Litopterna, Eoproterotherium, Notodiaphorus, Deuterotherium, Protheosodon, Coniopterotherium, Tricoelodus, Proadianthus

V. Typotheria, Archaeohyrax, Plagiarthrus, Prohegetotherium, Prosotherium, Propachyrucos, Phanophilus, Archaeophylus. Eutrachytherus, Argyrohyrax, Isoproedrium . . . . . . . . . .

11. Rhynchippidae, Toxodontia, Rhynchippus, Morphippu=, Eugeniops

VII. Leontinirdae, Leontinia, Ancylocoelus

VIII. Tesodontidae, Proadinotherium, Pronesodon, Coresodon, Interhippus, Nesohippus.

IX. Isotemnidae, Trimerostephanus, Pleurocoelodon, Lophocoelus. Henricofilholia

X. Homalodontotheria, Asmodeus................ I34

XI. Astrapotheria, Parastrapotherium .............. I 42

XII. Pyrotheria, Pyrotherium . . . . . . . . . $\ldots \ldots \ldots \ldots \ldots$

XIII. Rodents. Cephalomys, Scotamys, Litodontomys, Asteromys. Eosteiromys. ........................ $1 \varepsilon_{5}$

NIV. Edentata, Proeutatus. Prozaedius, Stenotatus, Proeuphractus, Peltephilus, Palaeopeltis, Glyptatelus, Hapalops, Octodontotherium, Orphodon.

XV. Marsupialia, Pharsophorus, Notogale, Prohorhyaena, Palaenthentes, Pilchenia, Callomenus, Pseuhalmarhippus, Parahderites.

Xil. Birds, Physornis, Loxornis. 



\section{PREFACE}

The results of the Amherst Patagnnian Expedition were divided into two parts, the general features, trogether with the narrative, were reported in a separate volume entitled, "Hunting Extinct Animals in the Patagonian Pampas," published in I913. For this volume has been reserver the description of the material found and such conclusions as are directly derived from that material. The material on which this work is hased has been prepared out and placed on exhibition at Amherst College.

The material here described forms a unified body of data, which arlds materially to our knowledge of the complete animals of the Tertiary period in Patagonia. There are beside this some small collections which offer some isolated new facts, but the working up of these has been reserved for the future for small articles, as the work may come to maturity.

The field has only been tousherd and a rast amount of further work can be profitably done on the horizons immediately preceding and following the one described in this volume, after which an interesting study can be made on the evolution of a fauna which developed in a considerable degree of isolation.

Narch 18, 1914.

F. B. Loomis. 



\section{THE DESEADO FORMATION OF PATAGONIA}

\section{CHAPTER I}

\section{INTRODUCTION}

THE material described and the conclusions drawn in the following pages are the results of the Amherst Expedition to Patagonia in I9II; an expedition organized and sent out by the Class of ' 96 as a part of their fifteenth reunion. The party consisted of Frederic B. Loomis '96, Phillip L. Turner 'I I, Waldo Shumway 'I2, and IVilliam Stein of St. Joe, Wyoming, and left Amherst July I, IgI I, returning the first of February the ensuing year, having spent its time collecting in the early Tertiary beds of Patagonia, as exposed in the Territories of Chubut and Santa Cruz, the aim being to secure from the earlier periods a fuller knowledge of the vertebrate animals, such as the Princeton Expeditions obtained for the Patagonian and Santa Cruz formations. The narrative of the expedition has been told in "Hunting Extinct Animals in the Patagonian Pampas."

Material was found in various beds, from the Cretaceous up to the Lower Miocene; but the major part of the fossils, and most of the facts new to science came from the work in the Deseado Formation. The collections from the horizon were so complete and interesting that this report of the expedition has assumed the form of a monograph of the Deseado Formation, otherwise known as the Pyrotherium beds.

The first work in this formation was done by Carlos Ameghino who at various times between 1889 and 1894 collected for his brother, Florentino Ameghino, the latter studying and describing the collections of Carlos, whose 
trips covered the country from Chubut down to the Straits of Magellan, and the various formations from the Lowere (retacents to the Pampean or Pleistocene. Carlos Ameghino and his hrother, Florentino, for years explored in Patagonia, going summer after summer at their own expense, and in the meantime maintaining a small book and stationery store in La Plata, the profits of which gave the two hrothers a living and furnished the funds for the continual expeditions. In the hack of the store was the workshop) from which (ame the continuous stream of knowledge in regard to these strange faunas. One of the best pieces of work clone by the brothers was the collecting and describing of the fauna of the Pyrotherium beds the bulk of which is contained in two papers entitled, Première Contribution à la Connaissance de la Fauna mammalogicjue des Couches à Pyrotherium, and Mammifires ('rétacés de l'Argentine, I)cuxième Contribution, ete., both published in the Boletin del Instituto Geografico Argentino, tomes 15 and 18 respectively. These two papers give names to most of the forms which we found, but the genera and species are hased on very fragmentary and incomplete material. It has been a pleasure to find the accuracy with which these descriptions were marle; and our part has heren chiefly to supplement and increase the knowledge of the various forms, and to determine from the more complete material the relationships of these strange forms. In some cases we have been able to assemble all the parts of the animals, and in the others to add more or less to the completion of the knowledge of the forms. There is one perculiarity of Ameghino's descriptions, namely the absener of data as to the localities where the forms were found.

Hout Iooo 'Tournier, in the interests of the Paris Muscum, marle a series of experlitions (5) to Patagonia, on some of which he found a Pyrotherium, or as he has termed it I)escarlo, locality just south of the Deseado River, 
from which he gathered a considerable collection which has been described by Albert Caudry in various papers mostly in the Annales de Paléontologie.

These two collections and their collahorations represent all the work thus far done on the Ieseado beds and fauna. Our collection is the first one of any considerable size to he brought to North America, and it seems to be hy far the most complete, the various animals being represented by more complete skeletons than in any of the previous collections.

The beds were first designated as the Pyrotherium beds, and are always so referred to by $F$. Ameghino. Tournier and Caudry, feeling the prejudice which is fairly general among Palaerntologists against names based on any contained animal (which may or may not be present at other localities, which may extend through more than one period, and whose name may he changerl as a result of further knowledge) used the term l)esearlo formation. as his collections came from the neighborhood of this river. This is a geographical name and aroids the chance for confusion; so I have adopted it throughout this paper. it being understood as an equivalent of the term Pyrotherium beds.

Ameghino never gave the exact, or anywhere near the exact, localities from which his Desearlo specimens came. It was not until 1906, when his Formations Sedimentaires* appeared, that any localities were designated, and there on a sketch map he indicates as Deseado exposures, about a dozen points, scattered between the upper part of the Chubut River to some 25 miles south of the I reseado River. These are included in an oval area some 500 miles long hy $5_{50}$ miles wide. Ameghino also suggests on this occasion that the I)eseado formation originally extended over at least the whole of this area. As will be seen in the next chapter, I believe that the deposits of this age

\footnotetext{
* Anal. Mus. Nac. Buenos Aires, ser. 3, t. 8, p. 99.
} 
and character have always been local and isolated. We sought for several of these localities and failed to locate them, especially those near Mazaredo, and the northern one on the Gulf of St. George. The point where we did find our material I helieve was one of Ameghino's localities, though the settlers of that region had never heard of anyone hunting for fossils there; but the settlement had been practically all within the previous six years, which was much later than the time when Carlos Ameghino worked in the region.

Beside the foregoing, an exposure of this age is reported by $A$. A. Romero, just above the fork of the two branches of the Rio Negro, which is some 500 miles north of the first group of localities mentioned. Ameghino also refers to another locality in the Province of Misiones which would be I.500 miles north of the typical localities.

The collections made by Tournier for Gaudry came chicfly from an exposure south of the Deseado River, some 15 miles above the mouth of the river.*

Our collection came from the Chico Branch of the ('hubut River, about three miles east of the river, and almost due west of Puerto Visser. As mentioned above on account of the close coincidence of the various species and hecause Ameghino indicates a locality in the neighborhoor, I think that our locality is the same as one of his, I should judge it the one from which he obtained a considerable part of his types. This is of importance; for, if in Ameghino's type locality, the determination of the speries, as the same as those of Ameghino's, is much more certain.

In the accompanying map I have indicated the localities given liy Aneghino, those of 'Tournier, and our own.

* Bul. Soc. Geol. France, ser. 4, t. 3, 1903, p. 468. 


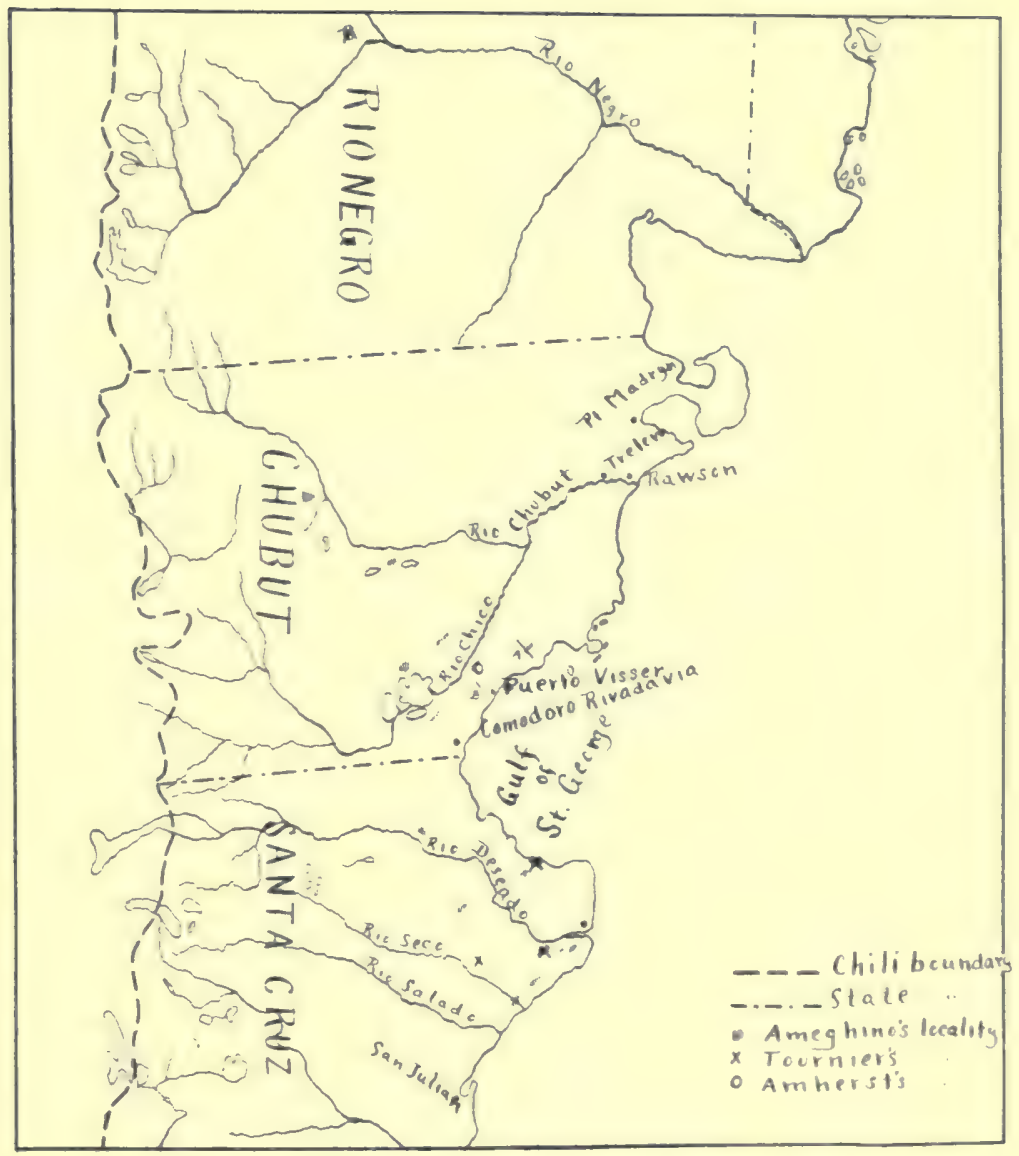

Fig. I. Map of Patagonia showing localities of Deseado beds. 


\section{CHAPTER II}

\section{Age of the Deseado Formation}

The locality worked by the Amherst party is situated about three miles cast of the Chico River, just across the line of the homestead of $\mathrm{D}$. J. Venter as plotted on the Plano de la (iobernation del ('hubut, igro, by A. Lefrancois. 'This would be $45^{\circ} \mathrm{I} 0^{\prime} \mathrm{S}$.. and $67^{\circ} 32^{\prime} \mathrm{W}$. (or as on the map 9 $15^{\prime} \mathrm{KI}$. of the meridian of Buenos Aires). The exposure is on all sides of an elongated hill about a sixth of a mile long, averaging 200 feet wide, and constricted in the middle to a narrow neck. Figure 2 shows a section of the hill, made along the north side, and indicates the varied character of the stratified deposits.

The material varies from brown sandy clay shales, to yellow sandy clay with concretions, and is capped with a varying layer of greenish sand, which, in some places, is coarse and irregular, in others fine and uniform, and in still other places is mixed with considerable quantities of voleanic ash. In it are many mud balls and also bits of bone which have been worn round, others but slightly llorn, and finally bones and skeletons which apparently have been luried where they fell. This green sand is mostly covered with a layer of two feet of hard sandstone of the same composition as the rest of the bed, but cemented into a dense layer. Above the green sand is a layer of fine grey sand, prettily crossbedded, and of varying thickness, lut without fossils. Remains of vertebrate animals cocurred in the brown clay, the yellow clay and the green silnd, and in all the cases fossils were of unusual abundance se that in this limited locality we collected over 300 specimens.

More the I)escado (layers 2 to 5 ) lies the Patagonian in it typical development, filled with Ostrea ingens, 


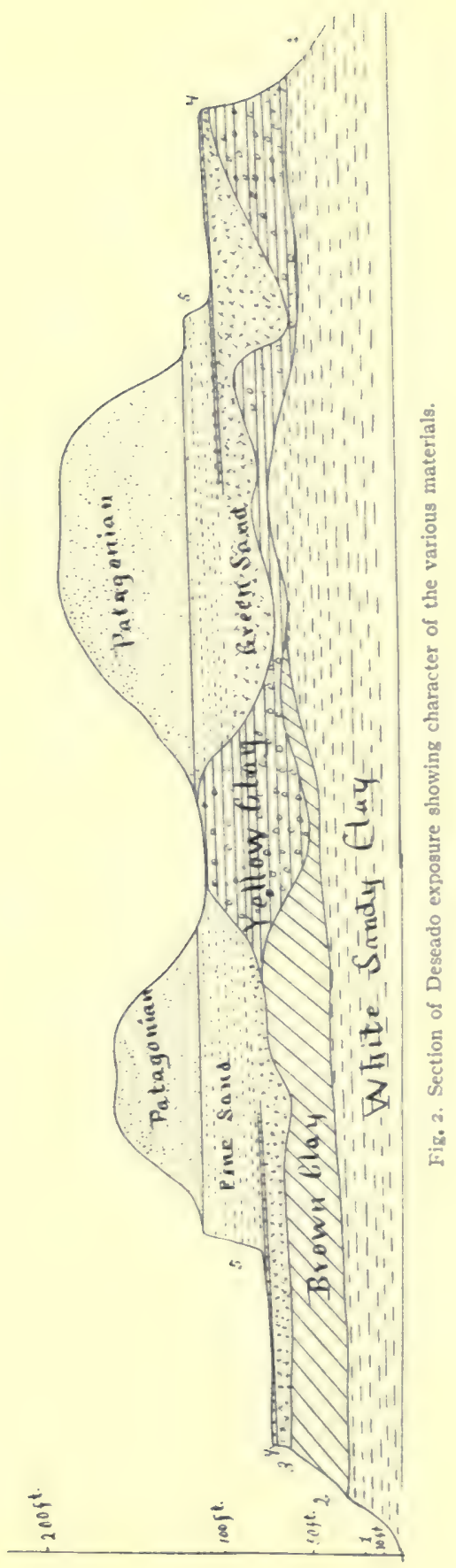


Turritcllas, Brachiopoda, sharks' teeth, etc. It is separated from the I eseado by a marked unconformity, one of the finest examples of unconformity I have ever seen. Evidently the upper surface of the Deseado was fairly new at the time of the transgression, or it is much disturbed by the transgression, the upper layers in places being broken up into sort of blocks and the crevices filled with Patagonian sands with the contained shells; just as I saw the beds on the seashore being disturbed by the waves of today. Then too in the basal foot of the Patagonian I found material which without question came from the underlyinp 1)eseado beds, various fragments of mammal bones bored by seashells, and with the Patagonian barnacles on them, but these were never more than a few inches up in the Patagonian. The contact was not horizontal, but in the micldle of the hill dipped down so that it came there onto the yellow beds of clays, and it was at this point only where we found bone's had been washed out by the Patagonian sea.

In the section the Deseado consists of layers 2 to 5 , the white sandy clay below belonging to the St. George series and being Cretaceous. The contact below was also an unconformity, clearly marked for the white sandy clay's were all horizontally bedded, while the Deseado is crosiberdeded in every direction, and has a distinct color. These white sandy clays of the St. George series are similar to the same beds as shown in sections A and B (figures 3 and 4 ), and extend in all directions for miles. Going down toward the Chico River one passes into the green shales that make up the upper part of the Salamanca and harl similar invertebrate fossils. About ten miles to the north was another bed of fossil trees similar to the one to les described on the Puerto Visser side of the pampa.

The character of the material making up the Deseado deposit, its variations in size and material, the presence of wom lebbles and bits of bone, show these layers to be a 
water deposit. The absence of any marine fosil in a bed otherwise rich in fossils indicated that it was a fresh water formation. The crossledeling, the irregularity of the deposits and the mud balls, prove that it was the work of a river. As there are no aquatic forms in the fauna I further conclude that it was the deposit of a temporary or intermittent stream, such as occur in arid and stmiarid countries. The layer could hardly be interpreted as a part of a flood plain; for it is very limited in extent, there being bluffs on three sides of our exposure. but in them no trace of the Deseado was found, nor was I able to pick up the formation again across the Chico River. Then the bedding is very irregular, much more so than is typical of flood plain deposits. The conclusion I reach then is that this Deseado pocket represents the bottom of an ancient stream, which flowed over a land surface made up of the white sandy clay's of the St. George age.

The age then of the Deseado beds must be older than the Patagonian, and younger than the white sandy clays of the St. George.

Is to the age of the Patagonian two very divergent positions have been taken, which may be best indicated by the diagram on page Io.

IVithout going into the history of the various positions which different authors have taken. and which will be found given in detail in Milckens' paper. or in less detail in Ortmann's. we will consider the positions of the most recent students of the question. Ameghino postulates a marine and a continental series of deposits being laid down more or less simultaneously: In the marine series below the Deseado, which is grouped as Guarantic, he places the Luisa, the Roca and the Salamanca, followed br a hiatus, then the Sehuen, which in turn is followed by another hiatus and the end of the Cretacenus is reached. The Patagonian is his Eocene. Parallel to the marine series is the terrestrial, where the Casamayor $1=$ Notos- 


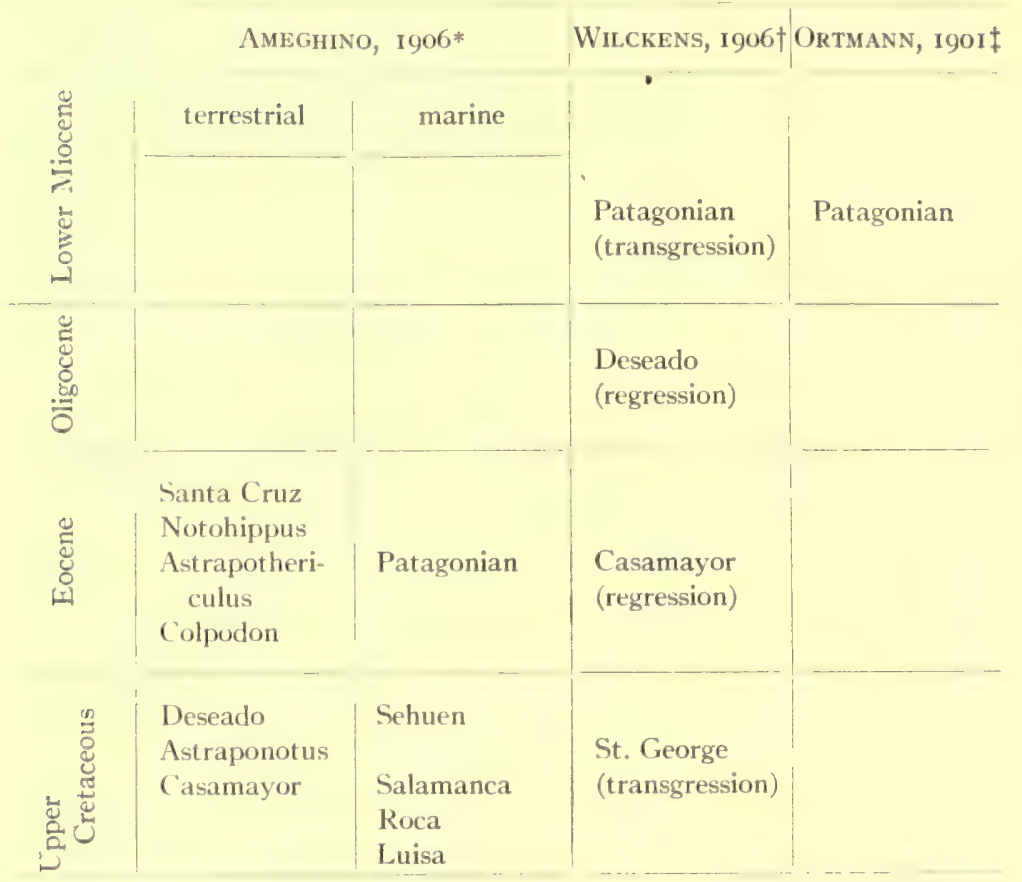

*Formations Sedementaires, p. 498, Anal. Mus. Nac. Buenos Aires, ser. 3, t. 8 .

$\dagger$ Neues Jarhbuch fur Mineralogie. bd. 2I, p. 193.

\$Princeton Expeditions Reports, vol. 4, p. 303.

tylops) is contemporaneous with the Salamanca, the 1)eseado with the Sehuen, and the Colpodon, the Notohippus and Astrapothericulus with the Patagonian, thus making the I)esearlo of Cretaceous age. After a very detailed study of a large series of Patagonian fossils, Ortmann concludes that the Patagonian is of Lower Miocene age. This is the most detailed study which has been made. Vilckens coincides with this view, though feeling that the latagenian may have extended down a trifle in to the last of the (Oligocene. This latter author finds a long gap between the Upper cretaceous and the Patagonian, a period when l'atagonia was above water. It was during this 
interval that the Casamayor, the Deseado and possibly. other beds were deposited on the continent. I have gone over Ortmann's argument, and studied a large collection of Patagonian fossils, both vertebrate and invertehrate, of my own; and while there are some places where we would like further data, I can come to no other conclusion but that these Patagonian beds are Lower Miocene, the exact relationship with beds in North America and Europe, being as yet not definitely settled. nor will this be possible until a study of the migrations of the elements of the Patagonian fauna has been made.

As to the beds underlying the Patagonian, I am sure that a considerable study of the marine series is still requisite to determine the relationships of the beds in different parts of Argentine, and their relative positions as compared with beds in other countries. Ameghino appended to his paper on the Formations Sedementaires a section of the strata exposed on the coast of Patagonia from Rio Negro to ('ape Virgenes, on which from above Punta Atlas south to below Pico Salamanca, the Casamayor (= Notostylops) beds fill the interval from the Salamanca formation up to the Patagonian. On the strength of this map I followed these. beds the whole distance looking for vertebrate fossils of Casamayor age. Nowhere did we find a Casamayor fossil. Instead at several points we did find marine fossils. I can not but feel that these beds are plotted as (asamayor. because of their resemblence in color and general texture to the beds carrying the Notostylops fauna at Casamayor.

Of several sections of these beds I pick out two as typical. and also because they are near the locality which we worked for the I eseado fauna. On the map they are inclicated as $A$ and $B$. The former passes through a beed of green sands which is, I think, the locality indicated as his northern locality for the Pyrotherium fauna.

From Punta Atlas to Pico Salamanca, Ameghino plots at or just below sea level a bed known as the Salamanca, 


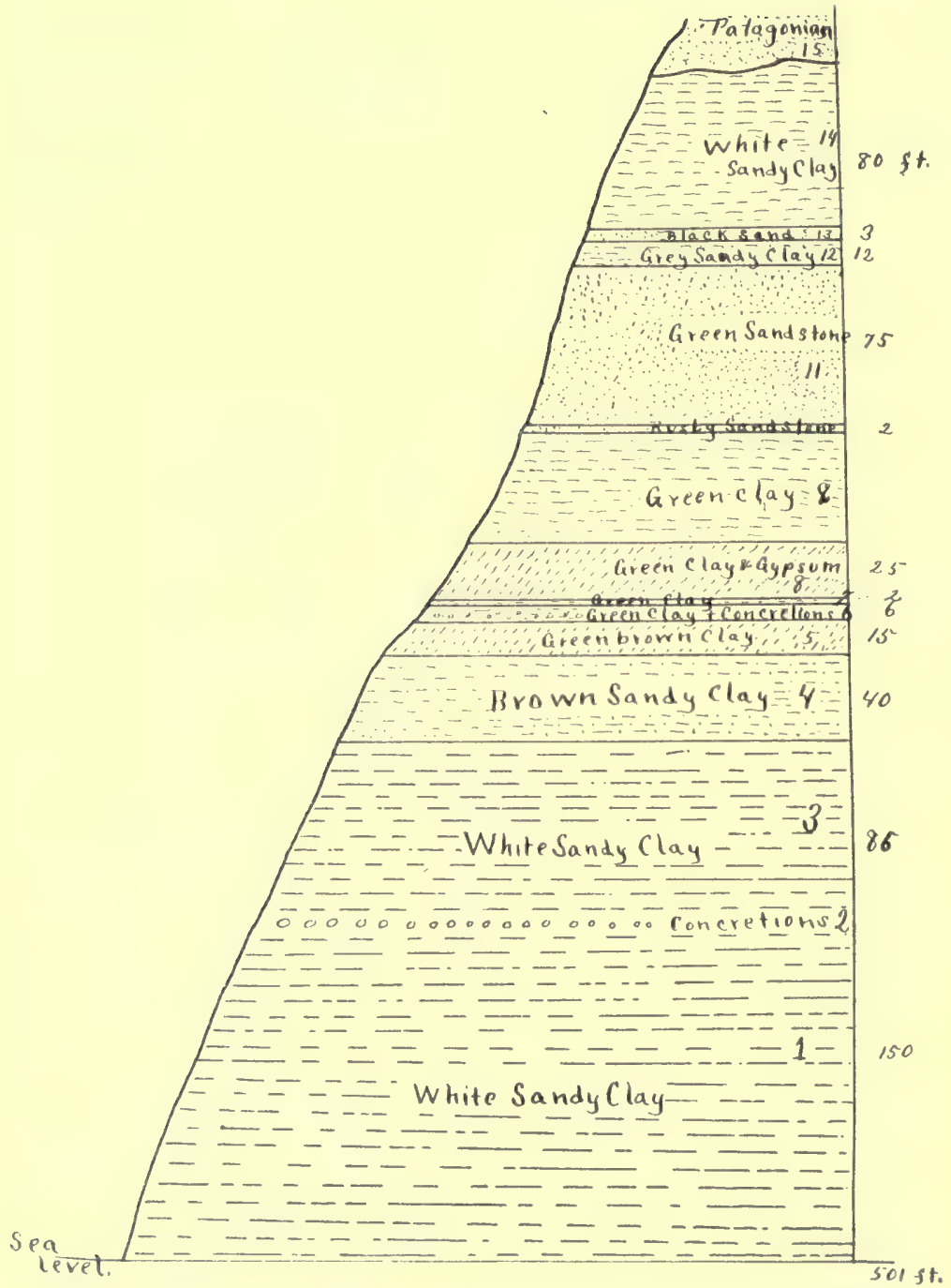

Fig. 3. Section at $A$ on map page 5, showing strata from sea level up to the Patagonian. 


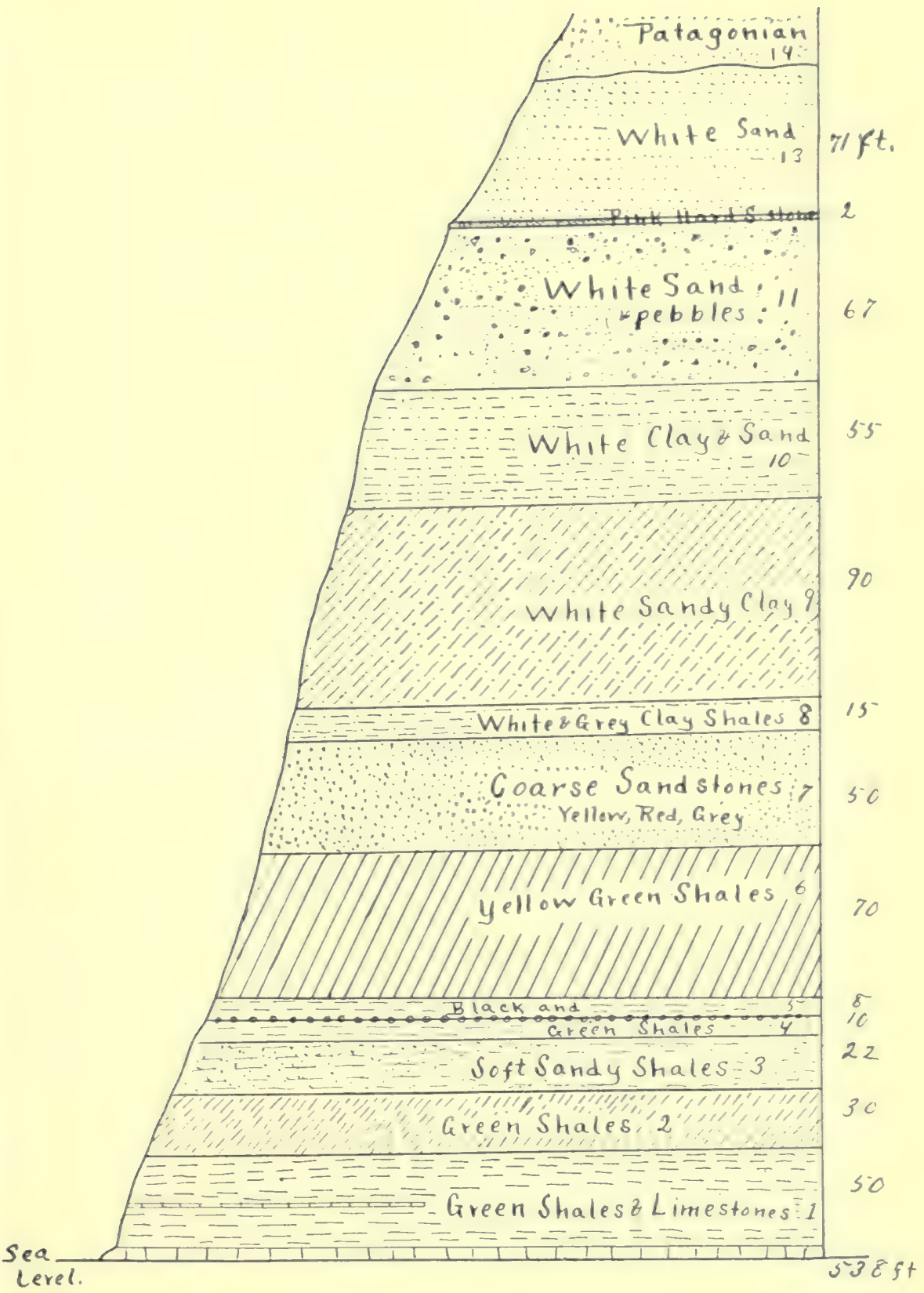

Fig. 4. Section $B$ on map, page 5, showing strata from sea level up to the Patagonian. 
being typically developed opposite Pico Salamanca. In this in the neighborhood of Pico Salamanca we found the fauna typical of this horizon.

Ostrea rostigera $\mathrm{v}$. Ih.

()strea riongrensis v. Ih.

Ostrea ameghinoi v. Ih.

Chlamys salamanca v. Ih.

Rostellaria striatissima $\mathrm{v}$. Ih.

Rostellaria sp.

(ytherea calcedonica $\mathrm{H}$.

I)iscinia sp.

I iplodon sp.

This Salamanca formation is considered by Wilckens as the expivalent of the Roca as exposed on the Rio Negro, and to the Luisa as exposed on the Rio Coyle. All agree that the Salamanca is U pper Cretaceous and a period when Patagonia was covered by the ocean.

In section $\mathrm{B}$ we found the above fauna in layer I which is just above sea level here. In layer 2 we found casts of delicate marine shells (30 to 40 in number), representing four or five species and as yet undescribed. They seem to represent a deeper water facies of the Salamanca. In fact all the shales represented by layers I to 5 evidently belong to the Salamanca. Layer 5 was distinguished by having in it at a point some 200 yards north of the section line a quantity of turtle shell fragments.

Layer 7 , consisting of coarser sandstones, was at the point of the section, simply filled with a vast quantity of fossil wood, most of it agatized, though some was carbonized, and representing some eight species, mostly pines and palms, the latter much scarcer. The tree trunks, hundreds in number, lay scattered in all directions; but all were lying horizontal, and there was no indication of stumps in place; (c) I consider that the wood was driftwood. It is common in the series of beds of this general horizon along the Culf of St. (ieorge. In the other layers up to the Patagonian 
we found no fossils. The contact with the Patagonian was unconformahle, in some places being 50 feet higher than in others near by.

In section $A$ the typical Salamanca is below sea level, and the lower parts of the section are made up of the white sandy clay shales, so typical all along the (iulf of St. (ierorge. In the midst of these clays at the level indicated as 2 orcurred a layer of concretions. On breaking these we found two specimens of Nautilus valencienni H., clear evidence that they were of marine origin. Layer 5 was fillerl with hundreds of the very characteristic oyster, describerl as Ostrea (Ciryphaea) pyrotheriorum. Though in earlier papers suggesting that $O$. pyrotheriorum represented a horizon of marine sediments corresponding in age to the Deseado (= Pyrotherium) formation, in his Formations Sedimentaires, Ameghino places this fossil in the Salamanca fauna, though it here occurs at least 275 feet alowe the typical Salamanca fauna. I believe the layer should be distinguished. It is later than the typical Salamanca, though belonging to the same transgression of the sea over Patagonia. In layer 7 we found still another marine fauna consisting of

Ostrea guarantica H.

Venericardia sp.

Corbula sp.

Aporrhais.

Patomides.

Oxyrhinca.

Milobates.

Fragments of the limbs of a crab in abundance.

This seems to be the same fauna as that described by Ameghino as the Sehuen developed on the Rio Seheun.

In layer 8 we found large quantities of gypsum, occurring mostly in balls of radiate structure. Layer I I was a coarse green sand, and in it we found some fragments of some sort of a bone. I think this layer is what Ameghino 
designated as a Deseado exposure; and it has the same general appearance and color which is found in the green sands of the Deseado pocket on the Rio Chico. However $i t$ is conformahle interleedded with the underlying and overlying marine beds and I consider it a part of the marine series. Above it come more white sandy clays that are characteristic of the most of the section.

Milckens takes all of this series, from the base of the Salamanca, up to the unconformity below the Patagonian, and makes of it his St. George Period, a transgression epoch, lasting to the end of the Upper Cretaceous. I believe it is all marine, and is all a part of the Upper Cretaceous transgression of the sea over Patagonia. However the Salamanca is a clear cut deposit and I feel it should be retained as a distinct horizon. The overlying light colored (white, grey, brown, yellow, or green) sandy clay shales represent a deeper water and later facies, which is characteristically developed on the Gulf of St. George, and may well be distinguished as the St. George epoch or series, but I should use the torm only in this more limited way. It is the same series which Ameghino has plotted as the Notostylops beds on his section of the coast of Patagonia. This last it certainly is not.

The unconformity between these white (or light) sandy clays and the Patagonian represents a regression period, during which Patagonia was not only above water, but extended an unknown distance further to the East.

It was during this interval of time between the I pper (retaceous and the Lower Miocene (Patagonian) that the limited and local land deposits known as Casamayor $(=$ Aotostylops), the Astraponotus, and the Deseado (= Iyrotherium) and probably other beds were laid down. In each case the age must be determined for the individual berl by its contents mostly; for as far as I know none of them overlap anywhere. 
In regard to the discussion as to whether Dinosaurs were contemporaneous in South America with the fauna of the Deseado. I can only say, we found no trace of a dinosaur or any other ( retaceous animal in the I )eseado beds which we worked. As the Cretaceous beds lie as high as the Deseado and are also practically horizontally striated. dinosaur remains might be found on the same level. I think the assigning of any such material to these heds was due to failing to recognize the unconformity under the Deseado heds. As to the Notostylops fauna and dinosaurs being contemporaneous. I only worked the Notostylops beds at Mazaredo. but there I found nothing to indicate the contemporaneousness of these two groups. As I have shown above. Ameghino's idea of the extent of the liotnstylops or (asamayor beds was mostly at fault. and very much of that which he has designated as of Notostylops age is I pper (retaceous. It is in these Ipper Cretaceous beds that dinnsaurs do occur and this seems to me to be the basis of the confusion.

This I pper Cretacenus series is a field where considerable work may profitably be done, in straightening out the relationships of the various layers to each other, their extent, and their relationship to the Salamanca and other Lpper Cretaceous formations in other parts of Argentine.

As to the age of the Deseado deposit which we worked. It is under the Patagonian, and therefore must be as old as the Oligncene. On the other hand it must he as young as the Eocene, lying as it does above the Ipper ('retacerous. Of the three general faunas described it is clearly more advanced than either the Casamayor, or the Astraponutus: so should be put as the youngest of these three. The Colpodon, the Astrapothericulus and the Xotohippus. faunas are said to be interstratified with the Patagonian and therefore of the same age. The amount of advancement from the Casamavor to the Deseado is considerable. and the relationships of the Deseado are fairly close with 
the various genera of the Santa Cruz; so that I should put the Deseado as far up) as possible toward the Santa Cruz. The santa (ruz is abme the Patagonian, and I think that the Deseado should he put just before the Patagonian; that is in the Oligocene, but just what part of the Oligocene can only be letermined when the other faunas have been further studied. 


\section{(HAPTER III}

\section{The Deseado FalNA}

THE exposure of the l exeade, which the lmherst party worked. vielded 20,3 specimens, each presumahly representing an individual. There were hesides these a few that were indeterminate and are not therefore included.) The consideration of the fauna as a whole suggests certain ideas as en the country in which the animals lived, and also certain comparisons with the fauna of the precerling and later faunas.

The first striking feature is the presence of so many excessively large animals, as Asmodeus, Purastrupotherium. and Pyrotherium, in each case forms larger than a rhinoseros. Further than that they are in each ease the largest members of their family, even larger than the representatives in the later santa ("ruz. This would indicate a period in which living conditions were at a high grade. suggesting both ahundance of fornd and a moderate climate.

The following talle will sive a groud idea as to the range of species, and their relative ahundance in the fauna, also a suggestion as to the clasis of food they used and from that an idea as to what sort of country they occupied:

Per NuM-

CENT BER

SPECIES

FOOD

COLNTRY

3 Hegetotherium shumwavi

7 Prosotherium garzoni

I7 Prosotherium triangulirlens

I Eutrachytherus grandis

+ Eutrachytherus spegazzinius $\left\{\begin{array}{l}\text { (irass, lark and } \\ \text { browse }\end{array}\right\}$ Plains

2 Phanophilus dorsatus

+ Argyrohyrax proavus

I Plagiarthrus clivus

It\% to TYPOTHERIA 


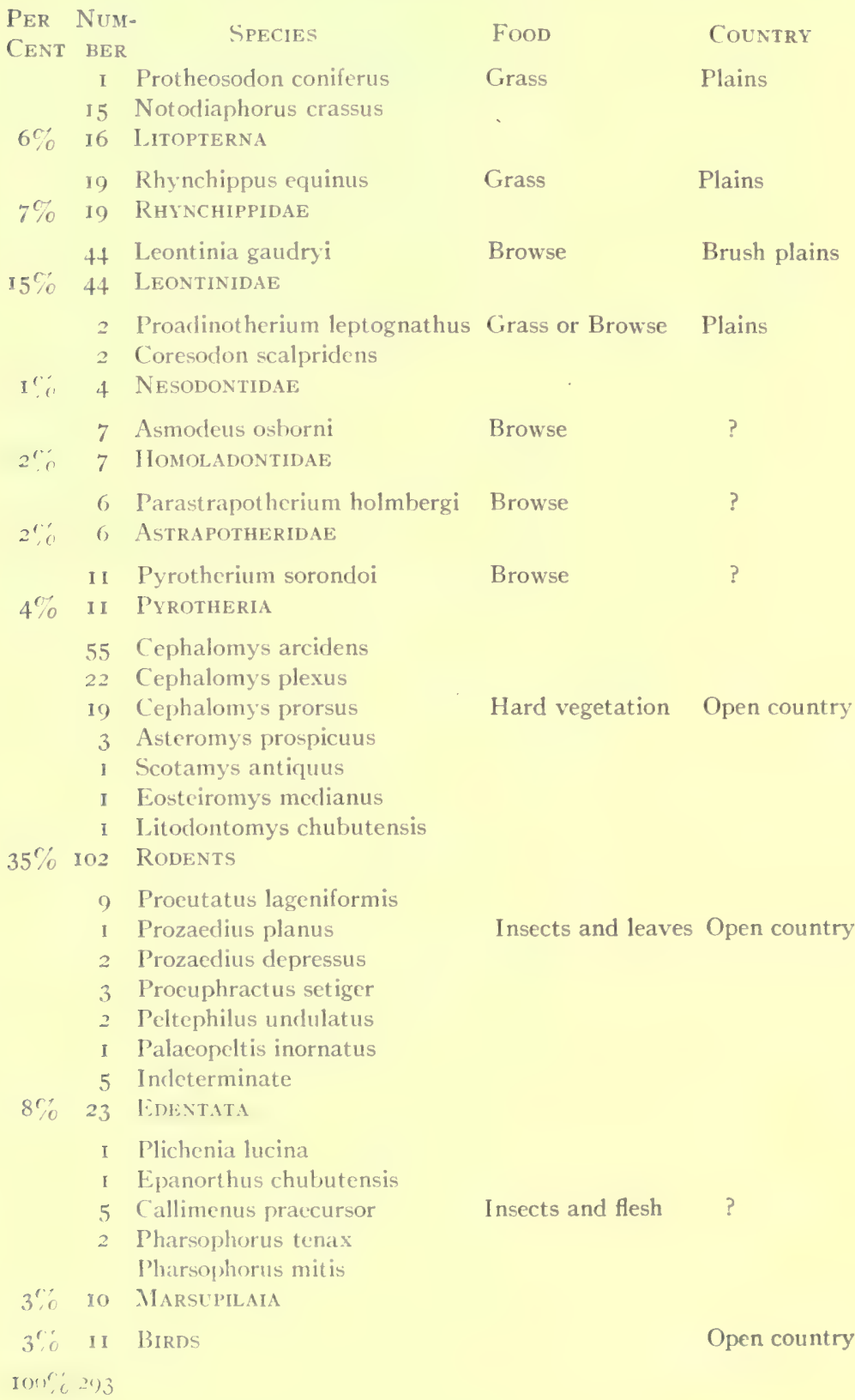


In our collection, all from one point, there are thirtynine different species. Beside these Ameghino has described a considerable number of species, some of which in time will probably turn up at our locality; but others and I think the majority will be found to be representative of other localities which he worked. It is to be expected that a difference of locality will make a little difference in the fauna. Further I expect that no two localities represent exactly the same period of time, though they may do so approximately; but some of these local deposits must have been begun earlier, and others probably lasted to a later period. Thirty-nine species of mammals and land birds is a fairly varied fauna for one spot; and the time element involved in laying down the 50 feet which separated the bottom from the top of the Deseado deposit is not probably very long: for the material of which the deposit is composed is of a character which would have been laid down fairly rapidly.

Of this fauna only 8 per cent belongs to the edentates; and if any element were disproportionately represented it would be this one, for the armadilloes have in addition to the skeleton the hundreds of tiny plates of the carapace, and several of the forms are represented by one or two plates only. When compared with the condition in the Santa ('ruz this 8 per cent is strikingly small, for in that later hed, fully $5^{\circ}$ per cent of the finds represent edentates. Are the Edentate just originating? Or, was the country less favorable to their habitation? The edentates which we did find are only slightly less advanced in their development than those of the Santa Cruz. Also, though infrequent, all of the families of the Santa Cruz are represented. It would seem therefore that the origin of the edentates was much earlier than the Leseado; and this relative paucity of edentates is also characteristic of the Casamayor and Astraponotus beds; but they are there. and in considerable variety, though small numbers. It 
would secm then that the country for some reason was less adapted to edentates, and that in some other part of South America they were flourishing and evolving.

In the Deseado the rodents appear for the first time in South America. 'They are all IIystricomorpha and in a relatively primitive stage of development, but they are typically developed already. Did they migrate in from some other locality, or were they evolved on the spot? Ameghino believer that they were developed from some such form as Promysops or Propolymastodon of the Casamayor, and that these forms were ancestral to rodents all wer the worlel. If my interpretation of the age of these beds is anywhere near correct, this last at least is impossible, for in North America and Europe typical rodents are present in the Eocene. Then as to even the hystricomorphs being developed in I'atagonia, I am very skeptical, for the material offered in evidence of this is very insufficient, especially in the region of the incisors; and may be interpreted in other more probable ways. I am confident that either just before the beginning of the I exscado, or at the beginning, the rodents of these beds migrated, either from some other continent, or at least from some other section of South America into this Patagonian region.

Some ideat of the type of country and the climate of the l)eseato period in Patagonia may be olstained by analyzing the fauna as to the character of its teeth as indicative of the food; and by studying the feet as indicative of the ground on which they were used.

The Typotheria with their chisel-like front teeth, lack of canines, and their permanently growing grinders evidentlyate a hard typeof vegetation. I)eepand permanently growing molars are characteristic of the eaters of grass, a form of vegetation which is especially hard on the grinding teeth, on account of the silica in the stems and leaves. This howerer would scarcely necessitate the development 
of permanently growing incisors. They are typical of gnawing animals, (aters of hark, twigs, and posibily also leaves, the wood and hark leeing also a hard type of vegetation togrind. In the catse of these forms I helieve they were feeders on grass and bark. Their feet are developeed either for running or hoppling and would suggest hard ground for their habitat.

The Litopterna are typically plains animals, paralleling in their development the horses. The croppling teeth and the grinding molars become progressively longer. The limbs are progressively chongated, the animals walking more and more on the tips of the toes. With this, the metapodials especially and the other limb bones to a less degree, are progressively lengthened. At the same time the sicle toes are progressively reduced. The teoth indicate grass eating; the limbs life on the plains.

The Rhynchippidae, while not as advanced as the Litopterna, show cropping front teeth, and the molars developing in depth. The locomotion is semicligitigrade, the feet small, and the number of toes reduced to three. 'They too must be interpreted as grazing or grazing and browsing animals, living on hard ground.

The Leontinidue are heavier forms, but with much the same features as Rynchippidace, though less specialized. On account of the broad upper molars and the less specialization of the dentition, I should feel that these forms were browsers and lived among hushes, but the feet were three toed and semidigitigrate and they seem to have walked on hard ground.

The Vesodontidue belong to the same type of adaptation as the foregoing family, lut have the grinding teeth more complicated, indicative of a more advanced adaptation to hard vegetation. The feet were also adapted to hard ground.

The Ilomalodontotheria, the istrapotheriu, and the Pyrotheria were all very large animals, known mostly by 
their dentition, which is adapted to browse. Whether they lived on soft or hard ground is not known, as the feet are not known in any case but the Homalodontotheridae, where they are five toed and adapted to soft ground. Such large animals were probably inhabitants of some river bank.

The rodents do not contribute much in the determination as to the type of the country, for they could have lived in the open or in the wooded country, but their relative abundance is rather typical of open country.

The birds are all running birds, and indicative of the country having been an open one.

()f our fauna I I per cent were flesh or insect eating, and for the purpose of determining the type of country may best be omitted. The rodents could have been either forest or open country forms. Of the remaining 54 per cent, the typotheres, the litopternas, the Rhynchippidae, the Leontinidae, the nesodonts and the birds ( 46 per cent) were distinctly adapted to live on hard ground; the other 8 per cent being evidently suited to living near a river. All 54 per cent ate either grass or browse. The litopternas are grass eaters; the typotheres were specialized to eat grass or bark; nesodonts, Leontiniidae, and Rhynchippidae are grass and browse eaters. Even the Pyrotherium has a pair of gnawing tushes. The picture arising from these considerations is a bush covered prairie, a country not unlike the upland bush pampas of Patagonia today.

There is not an aquatic form (fish or turtle) in the whole list, so it is evident that the stream which deposited these I escado beds was not abundantly inhabited. To me it looks like so many of the streams in an arid country, dry through a considerable part of the year, and so uninhabited. In the whole list I see nothing to indicate forests or swamps. The arid bush covered plain alone seems to suit the requirements.

As I se this fauna it is composed of several distinct clements, representing different invasions and an ele- 
ment which arose in situ. The reasons for the affinities expressed in the different groups will be found in the introductory paragraphs of the systematic discusion of each group.

The Votungulata, including the Typotheria, the Toxodontia, the Litopterna, the Homalodontotheria, and the Astrapotheria are a group with apparently a common ancestry. In Patagonia the have specialized in to the various subdivisions as we find them in the I teseado. This group was in Patagonia as early or earlier than the ('asamayor. Their relationships appear to me to be with the IIyrucoide which are generally credited with originating in Africa.

The Pyrotheria are related to the early elephants which also arose in Africa, but it seems to me that this form came to Patagonia at least at a later period, making its first appearance in the upper part of the Astrapunotus period. Lltimately the elephants and IIyrucoidea had a common origin in Africa.

The Rodentiu are all hystricomorphs and appear in South America for the first time in the I)esearlo. They also occur in the Oligocene of Europe and the Faym of north Africa. They never reached North America so must have come to South America by some southern route.

The Edentata are an element of the Casamayor fauna and as there is no evidence of their originating anywhere else it would seem that they were indigenous to south America, where they later flourished and develoned the greatest variety and profusion of numbers.

The group of marsupials is an element the origin of which presents a most difficult problem. Some belong to the oppossum series which could well have been developed from some remnant of the Mesozoic marsupial fatuna that had a world wide distribution; but the presence uf diprotodonts, which are characteristic of Australia. and of the Borhyenidue which are closely related to the Thylacinidae' of Australia, suggests a migration from that continent as 
late as Tertiary times; but to my mind this involves a connection which is most too difficult to postulate. There is no eidence that they came to South America in company with other faunas, for they have not been found asseriated with any other fauna outside of Southern Patagonia. The explanation of the affinities of the Patagonian marsupials with the Australian marsupials is a problem which is not yet in position to be settled.

The bircls probably came from Africa with the invasion of the ancestors of the Notungulates.

The idea of an invasion from Africa in I pper Cretaceous times, and possibly another at a later time is correlated with the other evidence of a land bridge between these two continents, as deduced by students of other groups.

Eigenmann, working on the freshwater fishes,*

Lydekker, studying the hystricomorphs, $\dagger$

Von Ihering, studying the freshwater mussels, $f$

Ortmann, studying the freshwater crabs, $\S$

not to mention several others studying mullocks, insects, plants, etc., have all postulated a land connection from Brazil to northern Africa during Cretaceous time to explain the distribution of their various groups. The divergence is in the time when this land bridge sank, some believing it to have lasted into Tertiary times, most feeling that it sank in Lpper Cretaceous times. Another body of evidence is presented to show that a land bridge connected the West Indies with the Mediterranean regions.: There was presumably but one such transatlantic connection. I ts position further to the south would seem to me to (xplain the distributional facts found in the West Indies, lut the striking resemblances between the faunas of Africat

\footnotetext{
* Princeton Expeditions to Patagonia, vol. 3, p. 310, r905 II.

$\uparrow$ llistory of Mammals, p. 127, 1896.

\$ Archhelenis and Archinotis, p. 125-I45, 1907.

$\S$ I'roc. Amer. Philos, Soc. Philadelphia, vol. 4r, p. 350, 1902.

|| See Scharff, Distribution and Origin of Life in America, Ch. 11, 1912.
} 
and south America recpuire a connection from the South Upper American Continent and Africa.

It was along this land hridge which the ancesters of the Sotungulata traveled, and when in South America, due te) their isolation, developed all the peculiarities of the group. This must have been not later than the latter part of the Cretaceous.

Either this bridge remained until into the early 'Tertiary; so the Pyrotheria and IIystricomorpha made their migration later, or these two groups did not reach the isolated Patagonian section until later than the first invasion. I am inclined to believe in the migration leeing at at later period. This bridge does not explain the presence of the edentates, for which there is every reason to helieve that they developed in situ. The Marsupial invasion must have been from some other direction, or their presence in Africa has not yet been discovered. 


\section{CHAPTER IV}

\section{UNGULATA}

The systematic arrangement of the South American ungulates is of such a nature that scarcely two students of these forms have agreed. I feel that the Pyrotheridae are probuscideans as did Ameghino, but there my agreement ends. The other varied groups I believe have a common ancestry, their great divergencies being due to adaptations to the greatly varied characters of the country they occupied. In spite of the great variation they have certain features in common so that I agree with those who have developed the term Notungulata to include them all.

From what source they originally came is not clear, but it seems to me that these notungulates have more in common with what we know of the African fauna of the Fayum than with any other fauna; so that my feeling would be that these two faunas had a common ancestry at least, and possibly the South American ungulates are derived from the dfrican. The lophiodont upper dentition, the bicrescentric lower molars with a "pillar" in the posterior crescent, the development of the tympanic bulla with the extension of the inflaterl cavity up into the squamosal bone, the derelopment of the post-tympanic portion of the squamosum, and the general arrangement of the basi-cranial foramena indicate in my mind that these notungulates have all risen from the same stock, and that that stock had much in common with the hyracoids.

I should therefore arrange the various groups as follows.

* The following references discuss in detail the arrangement of these forms Ameghino, 1906, Formations Sedimentaires, Anal. Museo Nac. de Buenos Aires, ser. 3, t. 8, p. 287-498: Roth, Los Ungulados Sudamericanos, Anal. Mus. La Plata, t. 5, 1903, p. I-36: Scott, Princeton Patagonian Expeditions, vol. 6, p. 287-299, 1912: Gregory, Bul. Amer. Mus. Nat. Hist., vol. 27, p. $27.3285,1910$. 


\section{NOTUNGULATA}

Order I. Ipper molars composed of an external lengitudinal crest and two transierse crests, the pesterior the less developed; lower molars composed of two joining resecents with a "pillar" in the posterior crescent; structure of the feet and limbs varying.

Suborder I. Litopterna: teeth hrachrdent to hrpsindont: lower molars with the anterior and posterior crescents subequal; squamoso-periotic region not inflated; limbs elongated; pes unguligrade; digits $3^{-3} .3$ or $\mathbf{I}-\mathbf{I}$.

Suborder 2. Typotheria: teeth hyposilont lower molars with the anterior crescent shorter than the posterior; squamoso-periotic region inflated; limbs elongated in varying degrees; pes plantigrade to semi-plantigrade; digits $5^{-}+$or $4^{-}+$.

Suborder 3. Toxodontia: teeth hrachydent to hypserdont; lower molars with the anterior crescent shorter than the posterior; squamoso-periotic region inflated; limhs short; pes semidigitigrade to digitigrade; digits $3-3$.

Suborder + Homolodontotheria: teeth brachydont; lower molars similar to those of Toxodontia; limbs moderately elongate; pes semidigitigrade: digits with large curved claws, 5-5.

Suborder 5. Astrapotheria: teeth hrachydont to moderately hypsodont; canines enlarged into tushes; molars similar to those of Toxodontia: limbs greatly elongated; feet unknown.

\section{PROBOSCIDEA}

Order II. (see page 68)

Suborder I. Pyrotheria: incisors dereloped into tushes: molars bilophodont; limbs short, especially the lower element; feet digitigrade. 


\section{LITOPTERNA}

This order of South American ungulates is less abundantly represented in the Deseado formation than in the Santa ( ruz, hut most of the genera of this latter formation have representatives in the Deseado so that they seem to have diverged still carlier.

By Scott the order is divided into two families, the Proterotheriidae and the Macrauchenidae, the less known Mliantidar being placed under the latter family until better known. I feel that I should prefer to retain the 1diantidue for the present, until they can be shown to be sulordinate to another family, so that in this paper the three families are retained. The striking features of the two larger families may be best brought out by a comparison of their chicf features as follows.

\section{Proterotheriidae}

Formula

I 043

Ipper inc. 2 and lower inc. 3 enlarged and tush-like, growing from persistent pulps.

Nasals normal

Nock short.

fieet with median digit enlarged, lateral digits reduced.

\section{Macrauchenidae}

3 I 43

3 I 43

Incisors, canine, and premolar I simple, compressed, subequal in size, and rooted.

Nasals shortened indicating a proboscis.

Neck long.

Feet with all three digits subequal in size.

\section{Proterotheriidae Ameghino}

In the leseado, this family is scantily represented as compared with the rich fauna, both as to speries and numleers of inclividuals in the Santa (ruz, but of the four chief genera of the Santa cruz, three have been found, though the remains are very fragmentary. They are the genera lioprototherium, belonging to the Prototherium series, Denterotherium belonging to the Thaotherium series, and Votodiuphorus representing the Diadiaphorus series. 
The following tahle will give what is known in comparing the two series.

\begin{tabular}{|c|c|c|c|c|}
\hline Proterotherium & $\begin{array}{l}\text { P'Ekion } \\
\text { Santa Cruz }\end{array}$ & $\begin{array}{l}\text { I'ppta Min.ars } \\
\text { metaconule present } \\
\text { protoconule and pentorone separatr }\end{array}$ & $\begin{array}{l}\text { NAcals } \\
\text { normal }\end{array}$ & $\begin{array}{c}\text { P's:s } \\
\text { tridactyl }\end{array}$ \\
\hline Eoproterotherium & Deseado & $\begin{array}{l}\text { metaconule present } \\
\text { protoconule and protocone separate }\end{array}$ & & \\
\hline Licaphrium & Santa Cruz & metaconule present & normal & tridactyl \\
\hline Diadiaphorus & Santa Cruz & $\begin{array}{l}\text { metaconule present } \\
\text { protoronule and protocone fused }\end{array}$ & short & tridactyl \\
\hline Notodiaphorus & Deseado & & & tridacty 1 \\
\hline Thaotherium & Santa Cruz & $\begin{array}{l}\text { metaconule lacking } \\
\text { protoconule and protocone separate }\end{array}$ & normal & monodactyl \\
\hline Deuterotherium & Deseado & $\begin{array}{l}\text { metaconule lacking } \\
\text { protoconule and protocone separate }\end{array}$ & & \\
\hline
\end{tabular}

\section{Eoproterotherium Ameghino}

Enproterotherium Amegh., Igot, Anal. Mus. Nac. B. A., ser. 3, 1. 3, p. H1.

The genus is founded on single teeth of the upper molar series, which, except for size, are very like those of Proterotherium. Limbs, etc., are unknown, so that this genus is simply a carrying back of the Proterotherium line into the Deseado. Ne found no teeth of this form, hut one species has been described, E. inaequifacies, of which I reproduce Ameghino's figure com-

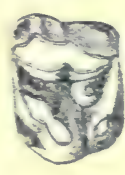

A

Fig. 5. A, Eoproterotherium

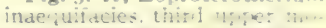
lar-natural siz.. C. Prother, therium karaikense, thir: upper molar-natural size. after Ameghino.

pared with Proterotherium, which shows this specien in have the metaconule better developed.

\section{Notodiaphorus gen. nov.}

The hasis of this genus is particularly a hind limb foumel associated which is much less developed than the santa Cruz genus Diadiaphorus to which it is most nearly related. These two genera are unique in having the ectal facet on 
the astragulus developed in two planes so that it appears as a deep notch. In the case of the new genus the toes are almost equal in size, giving us a stage in the development of this three-toed form which is much more primitive than the well-known Santa Cruz genus.

\section{Notodiaphorus crassus sp. nov.}

The specimen selected as type is number 3287 of the Amherst Collection, consisting of a complete pes, tarsus,

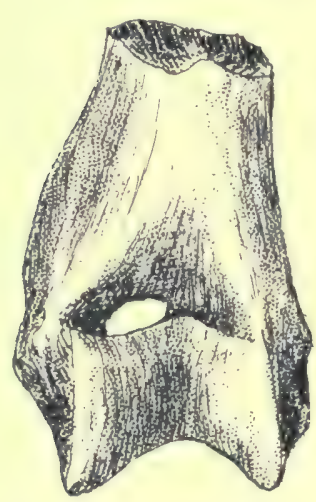

Fig. 6. Distal end of right humerus - I/ 2 natural size. lower end of the tibia, and the femur, from the Deseado on the Chico del Chubut River, west of Puerto Visser. Beside this, there are seven other specimens, mostly parts of hind limbs, but others having also the lower end of the humerus, the radius and ulna, metacarpals, and some phalanges. The species is distinguished by its large size, being larger than the species of the Santa (ruz, and, at the same time, the three toes of both the pes and the manus are subequal in size.

The distal end of the humerus associated indirectly with this species is moderately heary, with fair-sized epicondyles, and no entepicondylar foramen. The supratrochlear fosia is moderately deep, the anconeal very deep, the two being connected by a small foramen, as is typical for this family. The trochlearis, slightly oblique to the long axis of the shaft, has a simple pulley-like articular end without ridges of division, the internal border being narrower and higher than the external.

Measurements, Specimen 3201 


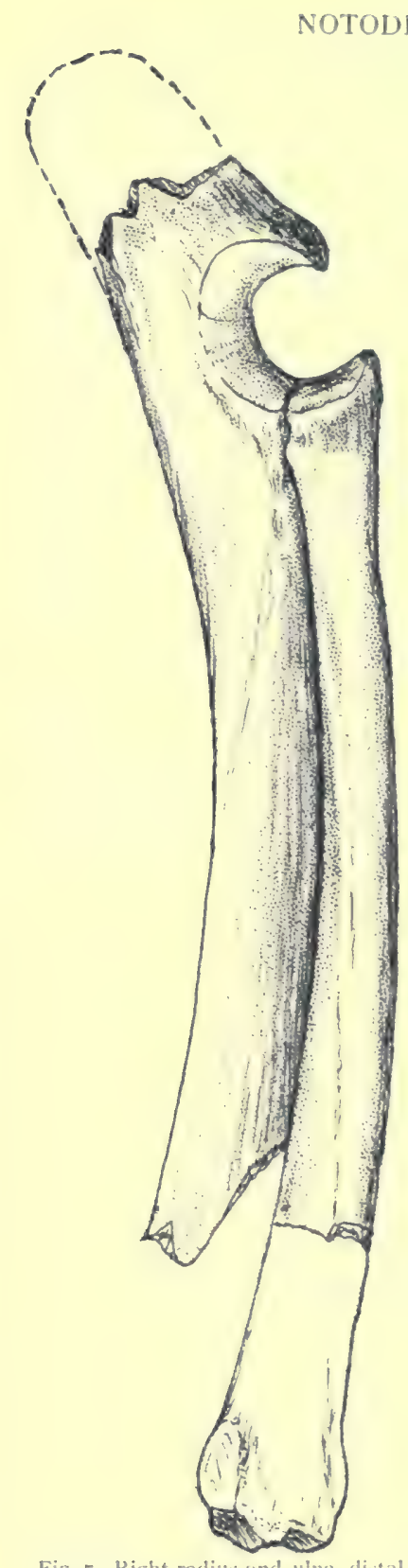

Fig. 7. Right radius and ulna, distal end of ulna from specimen No. 3275 I/2 natural size.

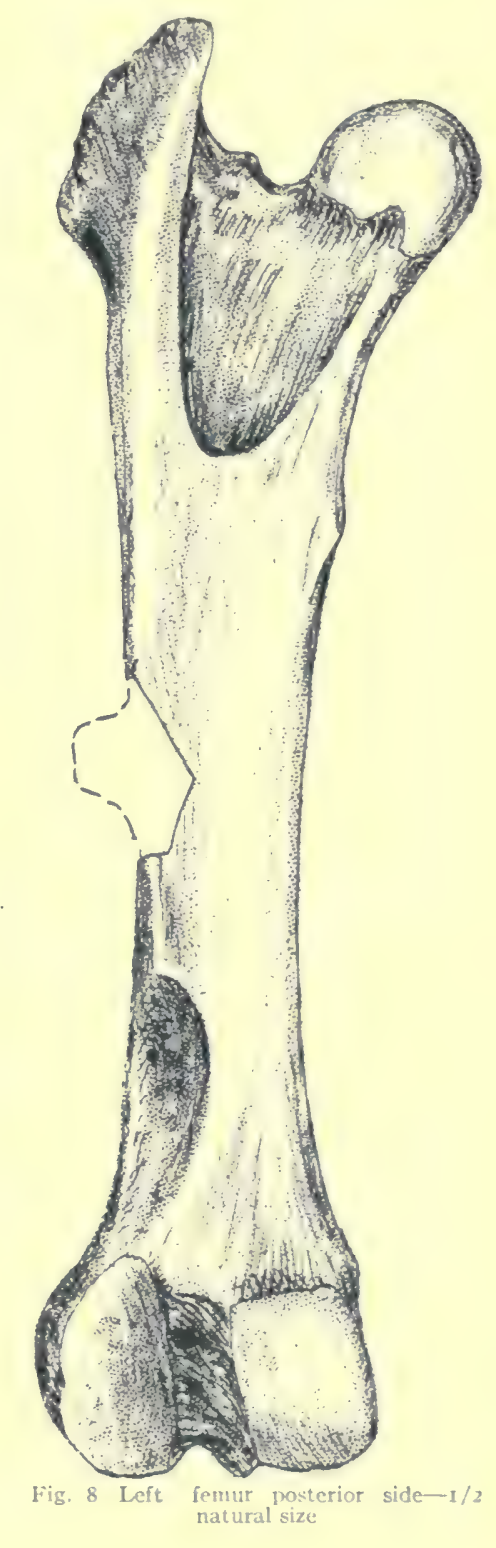


The radius and ulna were from another specimen which, however. was associated with a typical astragulus. The two bones are long, slender, strongly curved, and in contact with each other throughout their entire length, so that there could have been no rotary movement of the forearm. The radius is a slender bone with the proximal articular facet relatively small, the facet being slightly concave, of ovoid outline and with the transverse diameter the greater. There is but a tiny band-like facet for the ulna situated on the posterior side near the inner margin. Distally, the radius widens into a heavy end with a rugese area on the outer sicle for contact with the ulna, and with (wo) distal facets, a larger for the scaphoid, and a smaller for the lunar, the two being separated by a low ridge.

The ulna is heavier above, with a strong backwardly directed olecranon process. The sigmoid notch makes almost a semicircle, the articular surface being broad and extendling well onto either side of the bone. The facets for the radius are tiny. The distal end of this bone is wanting.

Measurements, Specimen No. 3275

Radius, length

greatest width at proximal end

$251 \mathrm{~mm}$.

greatest width at distal end

$28 \mathrm{~mm}$.

least diameter of shaft

$36 \mathrm{~mm}$.

$16 \mathrm{~mm}$.

The femur belongs to the type specimen which is about $5 \%$ larger than the other specimens. This bone is long and rather slender, with the greater trochanter rising well above the head, which is rounded, on a short neck, and has the ligamentary pit on the posterior margin. 'The thick, rugose, greater trochanter bends in over the head at its uppere end. The lesser trochanter is relatively small, and prolonged into a ridge. I'nfortunately the third trochanter is broken off in my specimen. The digital fossa is extremely large and deep. Proximally the shaft is flattened, but becomes rounded distally. Just above the 
condyles there is a deep rugese pit for the plantaris muscle. and on the anterior sirle the suprapatellar fosica is well marked. The condyles are placed a trifle oblipuely: the internal one being shorter and with a rounded articular face, the external ondyle leing longer, and with a flattened articular face which shoes oblipuely inward.

Of the tibia, only the distal end is preserved. This indicates a rather slender bone, with a shallow, fairly wide concavity for the external astragular trochlea, and a narrower and deeper concavity for the internal astragular trochlea. On the internal side of the tibia there is a rugose surface for the fibula.

An isolated lower end of a fibula indicates a slender bone, enlarged distally where it comes in contact with the tibia. The fibula carries on its inner face a moderately large facet for the external side of the astragulus, and on the distal end a wider one for contact with the calcaneum.

The tarsus is compactly built, wider than that of Diadiaphorus, because the external digits are not as much reduced. This especially shows in the greater derelopment of the cuboid and the mesn-

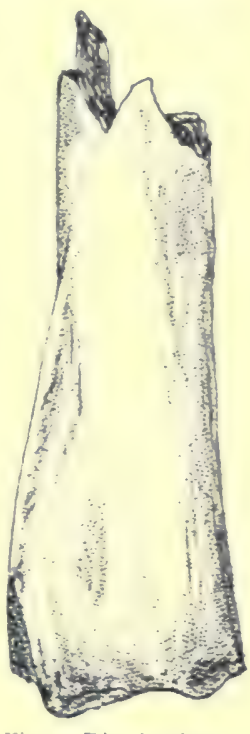

Fig. 9. Distal end of left tibia-1'a natural size. cuneiform, hut in other features it is similar to that of its descendant.

The astragulus is a very characteristic bone. The trochlea is asymetrical, the external condyle rising higher than the internal, and the median groove heing wide and shallow. On the nearly vertical outer face of the astragulus. there is a semicircular hand-like facet for the fibula. The trochea extends well around the top of the bone. allowing a wide movement of the foot. The neck of the astragulus is long and wide. carrying a broad flatened head. with its convex facet for the navicular, covering the entire end. On 


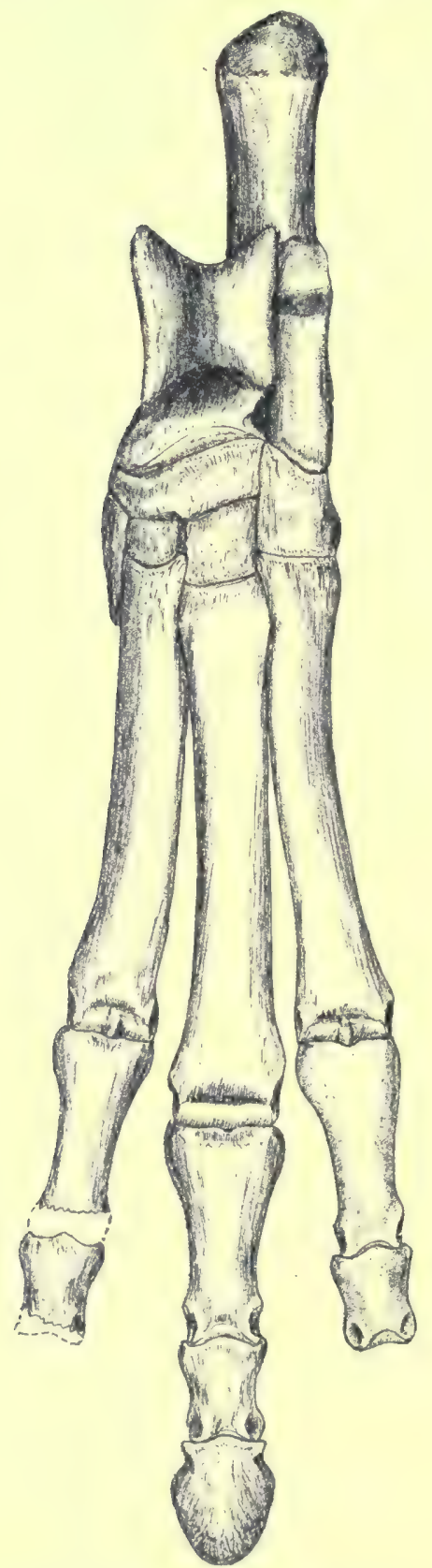


the plantar side are the most marked features. The ectal facet is in two planes, the anterior portion being bent down to nearly right angles with the posterior, which seems to be characteristic of this Diadiaphorus series. 'The sustentacular facet also is characteristic, being gently rounded and extending clear to the navicular facet on the head, in Diadiaphorus becoming actually confluent with the navicular facet. Just at the edge of this sustentacular facet is a tiny surface where the astragulus rubs on the cuboid,

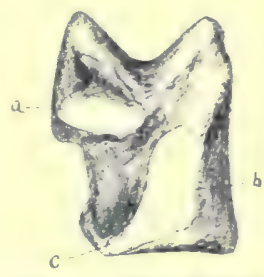

Fig. Ir. Ifft astragulus flantar side: : $d$, ectel latet - r i natural size; $b$, sustentaclilar tacet; $c$, fiact for cuboit. the only case, as far as I am aware, where this occurs in any Litopterna.

The calcaneum is long and slender, the tuber being but slightly enlarged, its sustentacular facet being a broad oval surface, while the ectal facet is in two planes to correspond to that on the astragulus. The facet for the cuboid is at the distal end, but is unusually oblique, its inner margin sloping up almost to the sustentacular facet. It is this slope which brings the cuberd in contact with the astragulus.

The navicular is broad and low, with a prominent hook behind. On its upper face there is only the loread facet for the astragulus hearl; on the lower face are three facets, externally, a large, more or less triangular area, for the ectecunteiform; medianly a smatler similar facet for the mesocuneiform; and on the internal siele, sloping up onto the internal face, a small facet for the reduced endocumeform. On the external face of this bone there is a tiny beveled facet for the cuboid.

The endocuneiform is a large scale-like osicle articulating on the lateral internal face of the navicular, and overlapping markerlly the inner surface of Metatarsus II.

The mesocuneiform is considerably reduced in size, carrying a broad tlat facet on the upper surface for the 
navicular, and a shallow saddle-like one below for Mt. II, which is entirely carried by this bone.

The ectocuneiform is considerably larger than the mesocunciform, resting above on the navicular, and carrying below the whole of Mt. III. On its inner side are two facets which rub against the upper end of Mt. II.

The cuboid is a nodular bone, its upper surface occupied by the facet for the calcaneum, the lower face occupied by

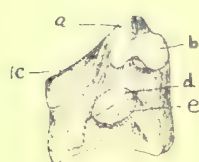

Fig. 12. Cuboid internal side to show: a, facet for astragulus ; $b$, upver facet for navicular; $c$, facet for calcavcum; $d$, lower facet for navicular; $e^{2}$. facet for mesocunieforms - I/2 natural size. the facet for Mt. IV, while on the external side there is a tiny beveled facet for the vestige of Mt. V, and with a small boss on the inner surface which carries two tiny facets, the upper one for the ectocuneiform and the lower for the navicular. On this same inner side, near the top) there is a second small boss, which carries a tiny facet to rub on the astragulus, and below that a second tiny facet for the navicular.

The pes consists of three digits, with a vestige of $\mathrm{Mt}$. V. Of the developed digits, the median one is the largest, but the two lateral digits are only a little smaller and were functional, so that this form was truly three-toed, comparable in the digital reduction to Mesohippus.

Mt. II is flattened above but soon broadens into a rounded shaft of considerable length, on the end of which is the articular trochlea, with the carina extending onto both the upper and lower surface, being, however, higher on the lower surface. Proximally this bone is overlapped by the endocuneiform, is carried by the small mesocuneiform, and also articulates on the inner side of the ectocunciform. Mt. III is also compressed at the upper end, hroadens below, and carries an articular trochlea similar to that of Mt. II, except that the carina does not extend so far onto the upper surface. Like Mt. II, Mt. IV is carried high on the tarsus, and therefore, though nearly as long as .It. III, it does not have the same effective length. 
Proximally it articulates entirely on the cuboid; distally it has a trochlea similar to that of Mt. II, the carina extending onto the dorsal surface. While Mt. I is lacking, it is clearly indicated that a vestige of it should have been present, as there is a tiny articular surface for it on the cuboid, and a rugose surface on the outside of Mt. IV:

The phalanges are long and have the articular ends swollen somewhat as in camels. The phalanges of the first row are nearly equal in size, each with the proximal trochlea deeply notched for the carina of the metatarsus; and with the distal trochlea simple, though slightly concave from side to side, and reflexed well onte the dorsal surface. The phalanges of the second row are shorter and simpler. and somewhat depressed distally. The ungual phalanges are flattened from top to bottom, of moderate size, somewhat longer than wide, and without any indications of a cleft.

Femur, length

Meastrements, Specimen

diameter across gr. trochanter

diameter of middle of shaft

diameter of distal end

Tibia, diameter of shaft

diameter at distal end

Calcaneum, length

width

Astragulus, length

width

Metatarsus II, length

Metatarsus III, length

Metatarsus IV, length

Phalanx I of digit III, length

Phalanx 2 of digit III, length

Phalanx 3 of digit III, length

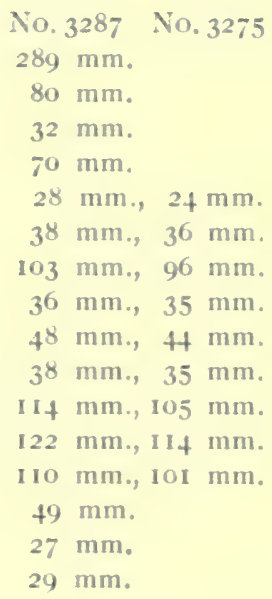

\section{Deuterotherium Ameghino}

Deuterotherium Amegh., 1895, Bol. Inst. Geog. Argen., t. 15, p. 633.

Deutorotherium Amegh., I 897, Bol. Inst. Geog. Argen., t. 18, p. 452.

This genus was first founded on a clacaneum and a bit of the mandibular symphysis, to which were added. later, 
both the upper and lower premolar and molar teeth. As far as it is known, it is distinguished by the upper molars lacking the metaconule entirely, and being approximately like those of 'Thaotherium. The dental formula is given by Ameghino at $\frac{043}{2}$, the same as Thaotherium. But one species has been described.

\section{Deuterotherium distichum Ameghino}

IIe dicl not find this species, but the teeth assigned to

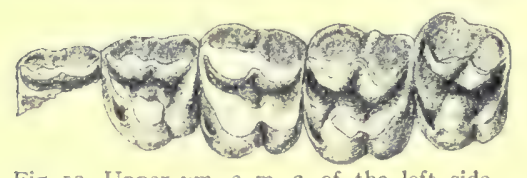

Fig. I3. Upper ym. 3-m. 3 of the left sidenatural size, after Ameghino. it are very characteristic, and so I reproduce Ameghino's figure of them. The species is distinguished by its size primarily. The following are the chief measurements given.

Upper dentition, pm. 3 to m. 3 , length $50 \mathrm{~mm}$. Lower dentition, inc, I to m. 3, length $80 \mathrm{~mm}$.

\section{Macrauchenidae}

\section{(= Mesorhinidae Amegh.)}

This family is distinguished, first, by the complete dental series in which none of the anterior teeth are developed into tushes; by the nasals being shortened, apparently in connection with the development of a proboscis; by its long neek; and hy its feet being permanently tridactyl, all the three toes being equally developed. In the Ieseado it is infrefuent, hut to it Ameghino has assigned two genera; Protheosodon, which he describes as similar to Theosodon, lut which I find much nearer to the (asamayor representatives of this family, such as Lambdaconus, though it foubless lxdongs to the series which is represented in the Santa ('ru\% hy Theosodon. He has also made a second genus, Conioptotherium, which represents a large Macrau(chenill, efual in size to Theosodon. This genus is based on the calcaleum and astragulus and seems to be rare. 


\section{Protheosodon Ameghino}

Protheosodon, Amegh., 1897, Bol. Inst. Geog. Argen., t. 18, p. 453.

Protheosodon, Amegh., I904, Anal. Mus. Nac. B.A., ser. 3, t. 3, p. 42 I.

This genus was founded on an upper second molar and the fourth premolar. I figure m. 2, and it will be seen that they represent a form little specialized, resembling in the. low crowns, plump cusps, and presence of both protoconule: and metaconule, the ('asamayor types, such as Lambdaconus or Didolodus, rather than the advaneed type like the Santa Cruz genus, Theosodon. We found a specimen with the lower jaws complete and with the hind limb complete, which, I am confident, is the same form, though I can not duplicate any texith, for we found no upper teeth; but in size they agree with Protheosodon, also in the primitive character; and, were one from the lower teeth te pustulate the upper, they would be just such as Ameghino has described under the name: Protheosodon. Therefore I have assigned my material to this grenus and specie's. It adds to the genus characters the fact that this form had a shorter back, relatively as well as actually, than Theosodon; that the hind limb, at least, was much heavier and also shorter than that of Theosodon, especially in the metatarsal region where relatively the elements are only about half as long. The pes is of the same character as in Theosodon. but again relatively much shorter. I believe in Prothesodon we have to do with a form intermediate betwe'n Lambdaconus and Theosodon, and nearer to the former.

\section{Protheosodon coniferus Ameghino.}

P. coniferus Amegh., I 897, Bol. Inst. Geog. Argen., t. I8, p. 453.

Ameghino has described two upper teeth. Specimen No. 3001 of the Amherst Collection from the (hico del Chubut River, west of Puerto lisser, adds to this the knowledge of twelve vertebrae iseren dorsal and five lumbar), the lower dentition complete, the left hind limb 
complete, and the right hind limb complete except for the femur. In general, the animal is about ${ }_{5}^{3}$ the size of Theosodon garrettorum, but in parts varies

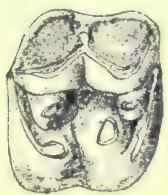

1ig. If. Typer molar. 2 of the right side-natural size. after Ameghino. from this as follows. The lower jaw is $\frac{3}{5}$, the vertebrae are $\frac{2}{5}$ in length, the hind leg is $\frac{3}{5}$ in length but $\frac{3}{4}$ in diameter of bones, while the metatarsus is only $\frac{1}{3}$ in length. This makes an almost plantigrade form of heavy, clumsy proportions.

Of the upper dentition we know only what Ameghino has given us. The molar is distinguished by the presence of both the protoconule and metaconule, by the development of the posterior cingulum and by the presence of three external styles.

\section{Measurements}

Upper premolar 4, length $12 \mathrm{~mm}$., width $15 \mathrm{~mm}$.

Upper molar 2, length $14 \mathrm{~mm}$., width $17 \mathrm{~mm}$.

In the lower dentition, none of the teeth are reduced, and all are in a continuous series, except that there is a
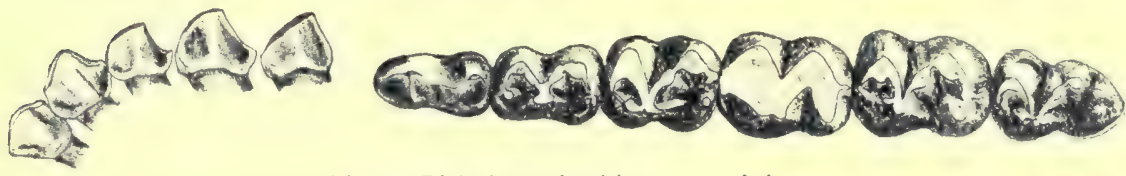

Fig. I5. Right lower dentition $\rightarrow$ natural size.

small diastema either side of pm. I. The incisors are simple, compressed teeth, with but a trace of a cingulum. the canine is incisiform and a trifle larger than the incisors. Premolar $\mathrm{I}$ is also incisiform, and is isolated by a small diastema on either side. The second premolar is longer and wider than the first, and begins to show molariform characters, the anterior portion being composed of a high compressed cusp, the posterior portion by a low crescent on which but one cusp is fully developed. The third premolar is composed of two complete crescents, and has the 
"pillar" already developed opposite the posterior end of the back crescent. In fact, the tooth is molariform, except as to the tiny extra cusp found on the molars. I'remoldr $t$ is more completely molariform comsinting of the -amse parts as the preceding tooth.

The molars may be distinguished by the presence of a tiny median (cusp) on the rear of the toxth, behind the orescent, which, when the toxth is worn, mates at median ypur to the rear. In both the premolars and molar-, the weth are characterized by their plumponen. and the i-nlation and lowness of the cusps.

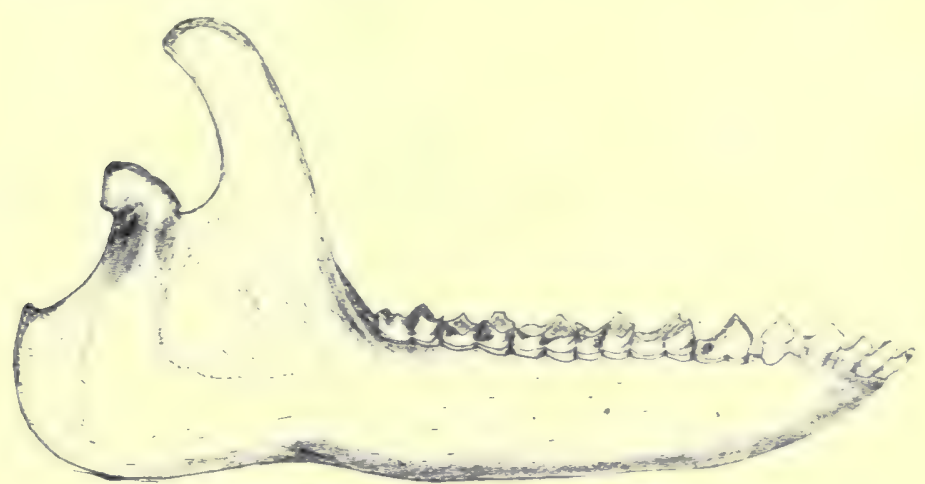

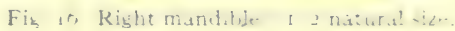

The two halves of the lower jaw are completely fured at the symphysis. The horizontal ramus in thick. hut low dorso-ventrally, giving the appearance of a clender jaw. The posterior angle is prolonged hackward and bent inward. The fossa for the masieter muscle, while larese is but faintly outlined. The aseending ramus hardly rises above the level of the teeth. exerent as the semder cormend projects to a good height above the articular condyle and curves backward over it. 
Measurements

Lower dentition, total length

I $4 \mathrm{~mm}$. incisors, length canine, length premolar 2 to 4 molar I to 3

Mandible, total length

height under molar I

height to top of coronoid
$20 \mathrm{~mm}$.

$8 \mathrm{~mm}$.

$35 \mathrm{~mm}$.

$42 \mathrm{~mm}$.

$188 \mathrm{~mm}$.

$24 \mathrm{~mm}$.

$95 \mathrm{~mm}$.

The dorsal vertebrae have short, wide, and somewhat depresied centra (in this individual the epiphyses are free, though this is the only indication of youth). The lewer ril, facets are small, that on the posterior margin of the centrum being a mere streak, while the one on the anterior margin is narrow. The upper ril, facet is a rounded conver surface on the end of a short stout transierse process. The prezygapophyses are convex surfaces, wide transversely, lut narrow in the anteroposterior direction, while the postzygapophyses are correspondingly narrow concave facets under the rear of the spines. 'The spines are thin and high, and the neural canal is nearly circular in section.

The lumbar vertebrae have laterally compressed, deep centra, with rery long transverse processes, shorting spines, and zygatophyses of the subcylindrical interlocking type. In all their features the verteluate resemble those of Theosodon, lexing nearly as highly specialized and in the same manner.

\section{Measurements of Tyical Vertebrae}

Dorsal vertebra No. 7 , length

width of centrum

$23 \mathrm{~mm}$.

$22 \mathrm{~mm}$.

Dorsal vertebra No. 9, length

$28 \mathrm{~mm}$.

Lumbar vertebra No. 2, length

$29 \mathrm{~mm}$.

Lumbar vertebra No. 2, width of centrum

$24 \mathrm{~mm}$.

L.umbar vertebra No. 2, width across transverse processes

$160 \mathrm{~mm}$.

The femur is short and very stocky. 'The rounded head is carried on at short neck, and does not rise nearly as high as the greater trochanter, the sulcus for the round liga- 
ment being a broat, deep notch on the pusterior margin. The greater trochanter is rugese, heavy, and high, hut not incurved at the toft. The lesere treshanter is a small, thin ridge well bedow the heal. The thirel trochanter is a large. thin process. projerting almost directly hackward, theugh curved inward at the end, and is situated well below the

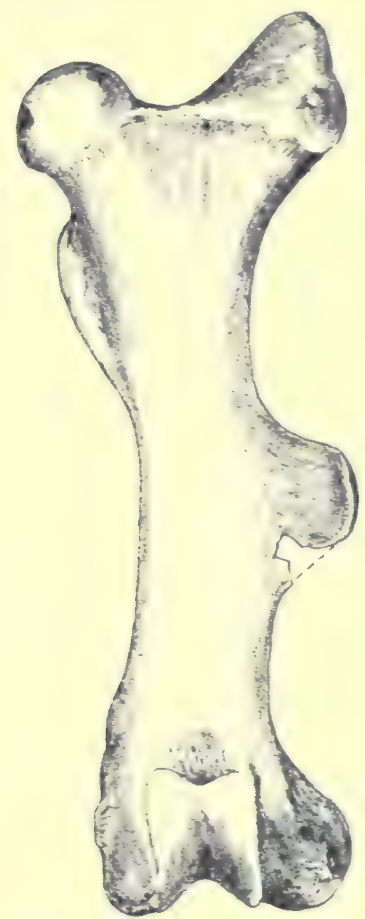

Fig. 17. I wit fonur anteriur sicle -1 indural size.

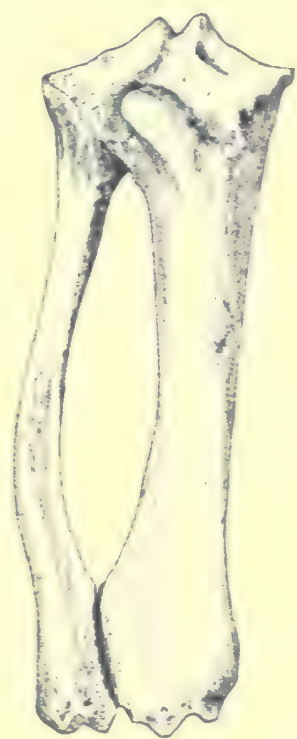

Fir. Is. Thitiat and ntwh (right)-1, 2 nactoral =:

middle of the lune. The shaft of the femur is Hattened above, hut thick, and changes in the lower part to suleylindrical. The condyles are small, suleyual in size, and widely separated, while the rotular trochlea is relatively wide and shallow.

The tilia is about three-fourths the length of the femur, very stecty and heavily huilt. On the proximal end, the 
convex external condyle is much narrower anteroposterinty than the larger and slightly concave internal condyle.

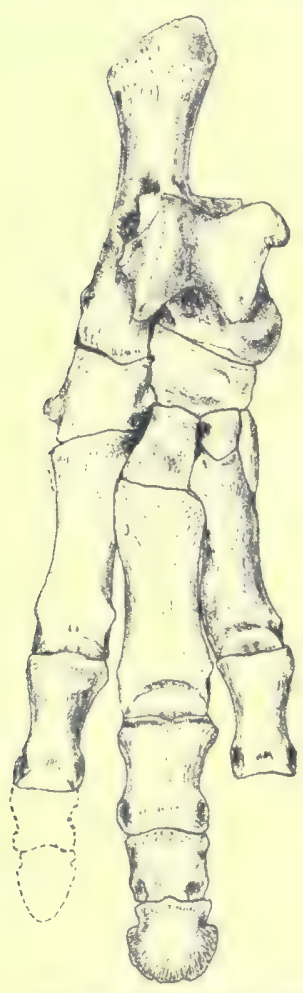

1.12 ie). Risht inst, the plitlanges in ontline from the lett foot $-1 / 2$ natural size.

The low spine is bifid. A cnemidial crest extends to the middle of the bone. On the distal end, the broad and shallow external articular facet is separated from the narrow and deeper internal facet by a low intercondylar ridge.

The fibula is fused to the tibia at the upper end, but is free below, being approximated to the tibia along a rugose surface nearly an inch long. This bone is rather slender and strongly bowed outward. Distally, there is a large facet for the outside of the astragulus, the back part of which rests on the calcaneum. This is peculiarly developed so that the articulation represents what is two separate facets, the one for the outside of the astragulus the other for the calcaneum. Here, however, they are blended.

While in general the tarsus is similar to that of Theosodon, there are some marked contrasts. The astragulus has an asymetrical trochlea with a shallow srowe, the external condyle being higher and narrower than the internal. The head is depressed in the dorso-plantar plane, is carried on a moderately long neck, and has a broad convex facet for the navicular on which alone it articu-

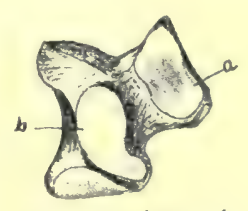

Fig. 20. Astragulus plantar side- $a$, exter nal facet; $b$, sustentacular facet-I $/ 2$ natural size.

lates. (On the plantar side, the ectal facet is broadly oval and dightly concave, differing from that of Theosodon in having no sulcus dividing it into lobes. The broad susforlarulat faret is slightly convex, and widely separated 
from the e'tal. on the external side the astragulus rarries an expanded articular facet for the inner side of the fitula. which, instead of leeing vertical, is expanded ledow, making an oblicue face which is continuous with the filuular facet on the calcaneum. In this feature Prothensodon is. as far as the feet are known, unique.

The calcanemm is a long bone with a club-shaperl expansion of the upper end. The fibular facet is small. heing continuous, as above described. with that on the outer side of the astragulus. On the face toward the astragulus. the ectal facet is broadly convex (not divided as in Thensolon). While the sustentacular facet is slightly concase. The distal end is occupied by the large concave facet for the cuboid.

The navicular is of moderate height, with a prominent hook behind. (On the upper surface is only the broad. dee'p facet for the astragulus: while the lower surface is divided into facets for the three cuneiforms, and the external distal margin is beveled to make a narrow facet for the cuboid. This navicular differs from that of Theosoden in that the facet for the ectocuneiform is not cut step-like into its external face.

The endocuneiform is a small scale-like bone with a narrow facet on the navicular, and overlapping the inner sicle of IIt. II. The mesocuneiform is small, with a Hat facet above for the navicular. and a convex one below for Mt. II, which is carried wholly on this bone. The extorcuneiform is far the largest of these three bones. and carries a hroad facet above for the navicular. a similar one lelow for Mt. III. a small facet on the internal side for the mesoruneiform and a second one below that for the side of Mt. II, while externally there are facets for the culuid and for the side of Mt. IV.

The cuboid is large, the external side being longer than the internal. The upper surface is entirely nccupied hy the facet for the calcaneum. while the lower face is mostly devoted to the facet for Mt. IV: with a narrow streak on the 
external margin for the vestige of Mt. V. The internal face carries a boss beveled ahove by the facet for the navicular, and below by the facet for the ectocuneiform.

All the metatarsals are short and heavy as compared with those of Theosodon. Mt. II is compressed above, but enlarges below into a subcylindrical bone, ending in an extensive articular trochlea for the phalanx, the trochlea carrying a carina which extends into the upper surface of the articular area. Proximally, it is so closely approximated to the adjacent metatarsus that these could have had very little independent movement. On the upper internal surface, there is a roughened area, where the endocuneiform overlaps this bone. Mt. III is slightly heavier than the others. On the distal end, its articular trochlea (xtends well onto the dorsal surface, as does also the carina. Mt. II is a trifle shorter than the others and stouter. Mlt. $V$ is alosent but its former presence is indicated by the beveled facet on the cuboid, and by the small roughened surface on Mt. IV.

The phalanges of the third digit are a trifle heavier than those of the other two digits, but of approximately the same lengths. The ungual phalanges were broad compressed hoofs, without traces of clefts.

\section{Measurements of the Hind Limb}

Femur, length from the head

$177 \mathrm{~mm}$.

greatest proximal width

$70 \mathrm{~mm}$.

greatest distal width

Tibia, total length

$56 \mathrm{~mm}$.

greatest proximal width

greatest listal width

Fibula diameter of shaft

Astragulus, length

wirlth

I $49 \mathrm{~mm}$.

$52 \mathrm{~mm}$.

$56 \mathrm{~mm}$.

$9 \mathrm{~mm}$.

$23 \mathrm{~mm}$.

$24 \mathrm{~mm}$.

Calcaneum, length

$62 \mathrm{~mm}$.

Metatarsus II, length

$45 \mathrm{~mm}$.

$48 \mathrm{~mm}$.

Metatarsus III, length

$42 \mathrm{~mm}$.

Phalanx 1 of digit III, length

$24 \mathrm{~mm}$.

Phalanx 2 of digit III, length

$16 \mathrm{~mm}$.

Phalanx 3 of digit III, length

$17 \mathrm{~mm}$. 


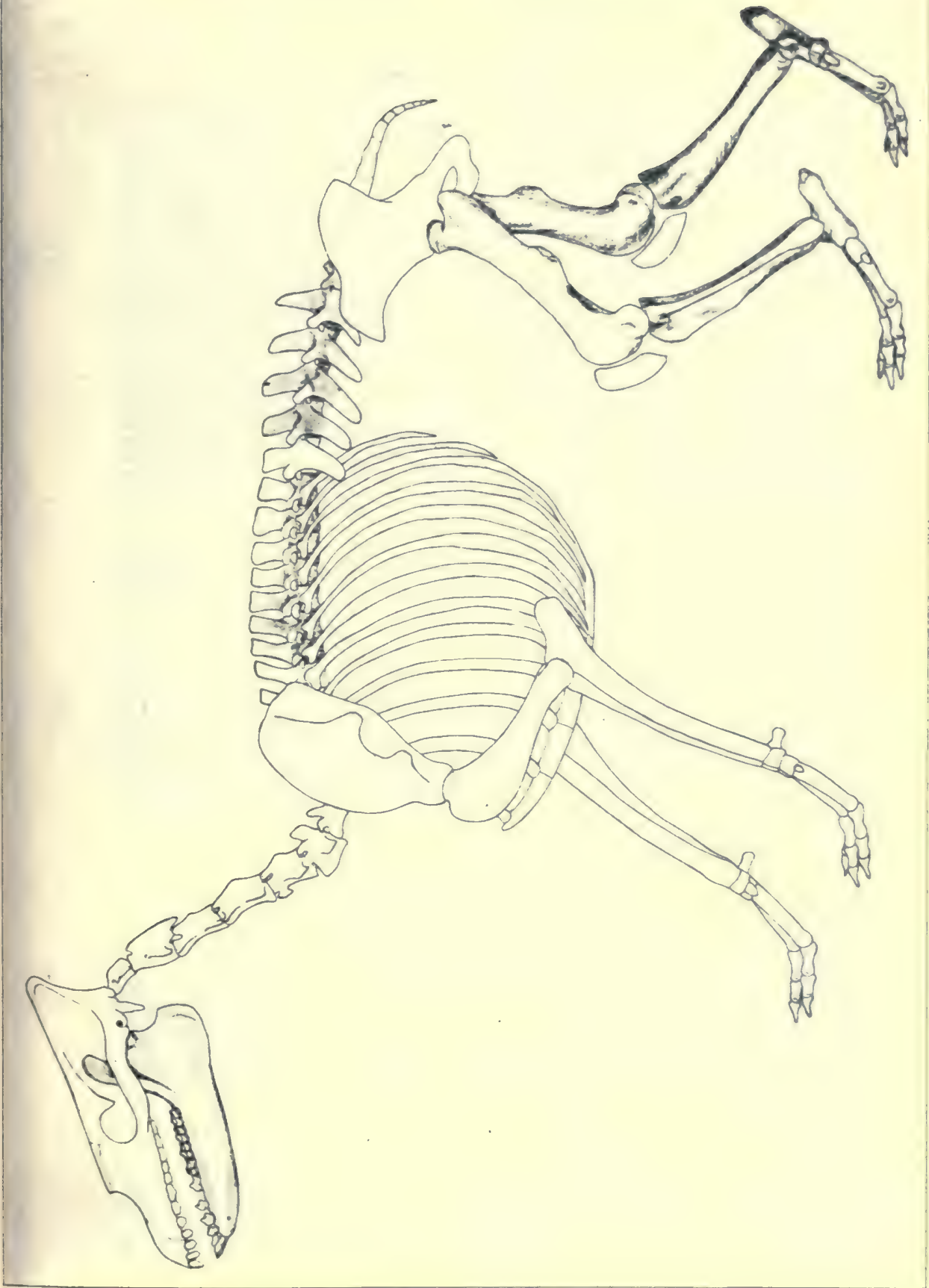




\section{RESTORATION .}

In order to get a comparison of what is known of this form with Theosodon. I have outlined a restoration of the animal as a whole, realizing that some essential parts are lacking, hut the general proportions can hardly vary greatly from those given. It appears, first, that this form has an unusually short back. Though the limbs and lower jaw are $: 3$ the length of those of Theosodon garrettorum, the vertebrae are $\frac{1}{2}$ as long. I have assumed that the number of vertebrae would prove to be the same as in Theosodon. While the limb bones are $\frac{3}{5}$ as long as in the Theosodon, they are relatively half again as heavy and with the processes much more developed. The greatest difference is found in the tarsus which is only $\frac{1}{3}$ as long as that of Theosodon, though relatively as heavy, and the foot was carried in a nearly plantigrade position the heel raised but a little from the ground, though the anticular ends of the metatarsals and the phalanges indicate that there was a considerable freedom of movement of the various elements. The form seems to be fairly close to the ancestral types such as Lambdaconus of the Casamayor, the limbs of which, however, are entirely unknown, but I should expect that when found these earlier forms would prove to be approximately plantigrade.

\section{Coniopternium Ameghino}

Coniopternium Amegh., 1895 Bol. Inst. Geog. Argen., t. 15, p. 632. Coniopternium Amegh., I 897, Bol. Inst. Geog. Argen., t. 18, p. 453.

The genus is based on a calcaneum and astragulus of the macrauchenid type, but of unusually large size. 'The real generic characters are not eviclent in the description, lut the presence of these bones, and of three cervical vertehrac, which we also found, indicating a macrauchenid of allout the same size, are evidence that a form larger than the Santa Cruz representatives will turn up in the Deseado herls, for which this name may be reserved. The material is described under the specific name $C$. andinum. 


\section{Adianthidae Ameghino}

This family is hased primarily on the genu- Arlianthus of the Santa ('ruz to contain some macrauchenicl-like form: which, however, are of much smaller size, and differentiated hy the narrow character of the teeth and their early tendeney to hypsodonty. It seems to be a valicl series of dwarl types, which are all scarce and known only by the most fragmentary remains. Two genera are described from the Desearlo. Tricoelodus, peculiar in having the posterior lobe of the lower molars somewhat subdivided so that the touth appears three-lobed; and Proadianthus. known only by premolars which however show an unusual development of the styles on the inner side of the teeth.

\section{Tricoelodus Ameghino}

Tricoelodus Amegh., 1897, Bol. Inst. Geog. Argen., t. 18, p. 454.

The genus is hased primarily on the three-loherl character of the molars, which is a secondary effect of an infolding on the inner side of the posterior lobe. They are runted. but strongly hypsodont. The margins of the crescents are well developed and the "pillar" is a prominent feature in the posterior crescent.

\section{Tricoelodus bicuspidatus Ameghinı}

T. tricuspidatus Amegh., loc. cit. ahove.

The species is the only one known of the genus. and its features are those of the genus. The following measurements indicate the size. lower pm. 3 to $\mathrm{m}$. I, $25 \mathrm{~mm}$; height of the mandible under molar $\mathrm{I}$ is $12 \mathrm{~mm}$.

\section{Proadianthus Ameghino}

Proadianthus Amegh., 1897, Bol. Inst. Geog. Argen., t. 18, p. 455.

This genus is known only by the last two premolars of the lower jaw, which are compressed and molerately high. 
The twe crescents are markedly separated by a cleft from the external side of the tooth, opposite to which is a high denticle, made by the fusion of the two ends of the crescents where they come together.

\section{Proadianthus excavatus Ameghino}

P. excavatus. Amegh., loc, cit. above.

The species is based on the two lower premolars described above. I reproduce the figure given by Ameghino. The measurements are: length of pm. 3 and

4 , $10 \mathrm{~mm}$.; height of mandible under $\mathrm{pm}$. Fig. 23. Lower right $\begin{gathered}\text { ind } \\ \text { size, after Ameghat }\end{gathered}$ 4, $8 \mathrm{~mm}$.

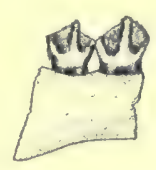




\section{CHAPTER V}

\section{TYPOTHERIA}

In the Deseado beds this group of running and hopping animals is well represented, making about it of of the Amherst collection, and varying in size from a little larger than a rat to larger than a sheep.

The group all have the front teeth modified into cropping or gnawing types, which grow permanently from persistent pulps; and the back teeth also growing through the whole or a large part of life, and also rootless, the crowns being variously infolded to make grinding surfaces. The skull is flattened abore, and abruptly truncated behind; the cranium being large and swollen, the facial portion broad above and excavated on the sides. The orbits are centrally located, of considerable size, and unbounded behind. 'The' tympanic bulla is swollen and may be hollow or filled with cancellous tissue. This cavity of the tympanic is continued above and expands in the upper part of the squamosum, making a swollen capsule on either side of the hack of the cranium. The openings of the auditory meatus are well back and in a tubular growth of the periotic which is directed back, and upward in an entirely characteristic manner. The strong paroccipital processes project far below the base of the carnium. The concase palate is wide and carried well back behind the teeth ending in two strong pterygoid processes. The mandible is deep, especially the back portion; has a slender coronoid process, and a small rounded articular condyle which would seem to indicate a forward and hackward motion of the jaws. On account of the agreement with these general features, I have placed among the Typotheria the furms which Ameghino classified as Hyracoidea. 
While agreeing in the above general features, there is great variation among the various forms. The first upper and lower incisor may be greatly enlarged or of normal size. There is a tendency for the third upper and lower incisor, the canines, and the first premolars to be reduced and disappear, and all intermediate grades are found. In the molars there is a regular tendency toward simplification; so that in the upper molars of the earlier forms there is a deep inner fold and a more moderate outer fold, either or both of which may disappear completely, though in one series the fold seems to have been accentuated instead of lost. The feet may be adapted to running or hopping.

In the Deseado and Santa Cruz material, four series of modifications may be distinguished which I have designated as families; (I) the Archaeohyracidae, primitive forms in which the incisors are little enlarged, with inner and outer folds on the molars, those on the inner side of the upper molars being very deep, bulla small, feet unknown; (2) Interatheriidae, first upper and lower incisors rooted and of moderate size, inflexions on both the inner and cuter sides of the molars, bulla large, feet adapted to running; (3) Hegetotheriidae, incisor I of upper and lower dentition greatly enlarged and rootless, molars simplified, bulla large, feet adapted to running or to hopping; (4) Eutrachytheridae, large forms with the first upper and lower incisor enlarged and rootless, the upper molars with the inner fold developed and bifurcated, bulla large, feet unknown.

For comparison of the various genera, they are charted on page 55, the dental character being used, as but few have the skeleton known, which is especially so of the earlier genera.

from the foregoing chart and the comparative figures of the upper and lower dentitions, the variety and at the same time the homogeneity of the Typotheria is evident. The gnawing front teeth resemble those of rodents, espe- 


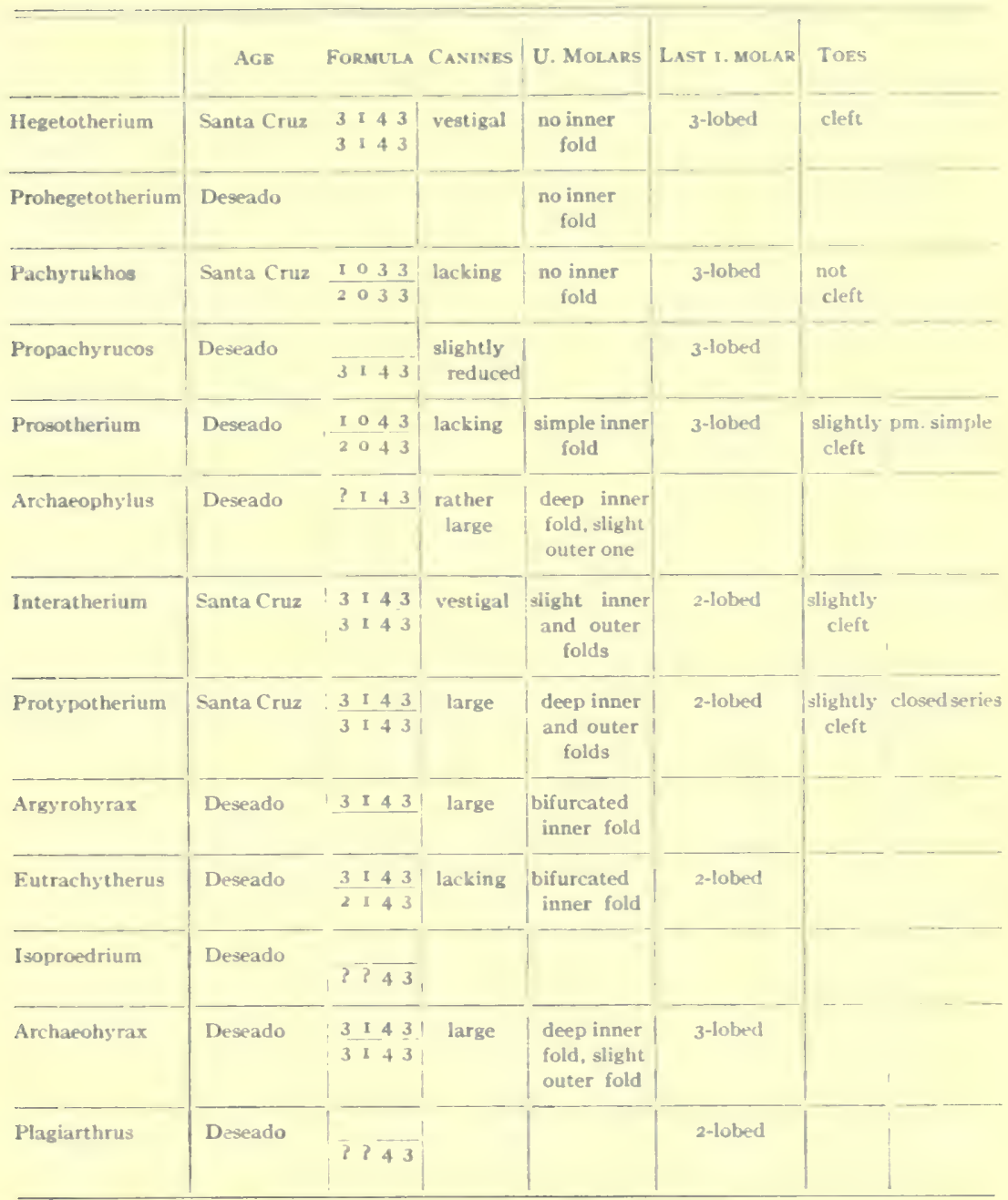

cially in the genera where the enamel is lacking on all hut the front face, but this is entirely a parallelism and there is no evident phylogenetic relationship. As to affinitics with the IIyracoidea, Sinclair* has carefully balanced them and finds so little in common between the two groups

*Princeton Expeditions Reports, Vol. VI, p. $7,1909$. 
56

THE DESEADO FORMATION OF PATAGONIA

$a$

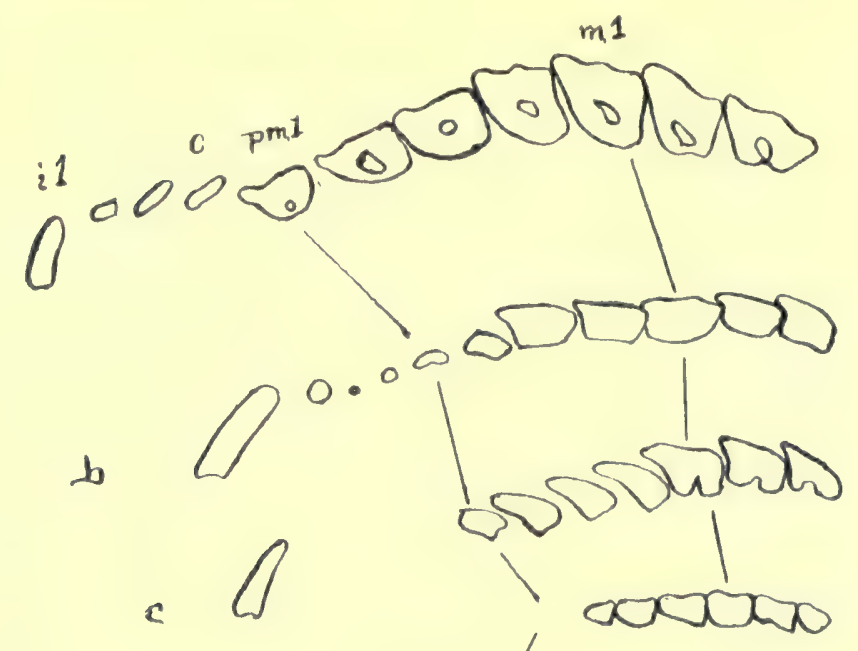

d.
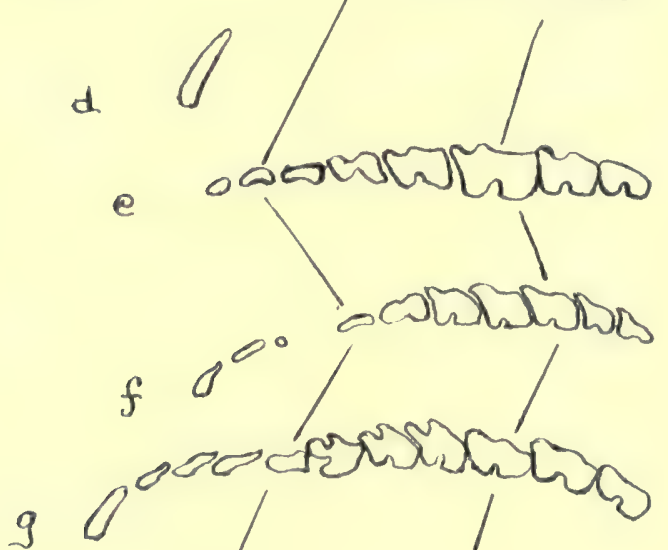

$h$

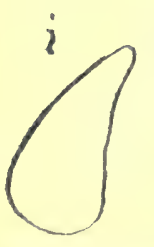

00

Fig. 24. Comparative series of uper dentitisns of Desearlo and Santa Cruz Typotheria; $a$, Archaeohyrax patagonicus; extensum: Protsutherium australe; $h$. Arusrohyras proavus: $i$ Eutruchotherus spegazzinianus-all natural size. 
that he makes them a separate suborder. I find certain features in common, like the lophodont dentition with the tendency toward hypsodont incisors, the inflation of the tympanic and the extension of this up into the periotic region, and the general arrangement of the basicranial foramena. On the other hand, there are also numerous features in common with the Toxodonts, and several peculiar to the group, so that I would feel that all the Notunsulates are descended from the IIyracoidea, and this group) has developed its peculiarities in South America, retaining however a little more of the hyracoid aspect.

The Archaeohyracidae are the most primitive of the Deseado forms, but as all the families are already separated before this time the Deseado genera can not be considered as the ancestral ones, though they seem to have retained more of the primitive features.

The Interatheriidae represent an offshoot line of development in which the incisors are not much enlarged and the infoldings of the teeth remain. The genus Archaeophylus seems to be directly ancestral to the Santa Cruz genera Interatherium and Protypotherium. In the family Hegetotheriidae there is a strong tendency for the incisors to develop into very large gnawing teeth, while the lateral incisors, the canine and the first premolar, tend to drop out, and the molars become more simplified. Propachyrucos seems to represent a hold over of the most primitive type: of these. The Prohegetotherium and IIegetotherium have retained the less specialized feet and less advanced type of teeth, while Prosotherium has tended to the development of the hopping mork of locomotion, which is at tained in Pachyrukhos later. There thus seem to be two series inside of this family. When the material is better known, it may be best to separate the two series. The Eutrachytheridae have retained the complexity of molars united with a permanently growing incisor. They seem also to have developed into a series of comparatively large forms, 
which, as they have advanced, have developed a bifurcated fold on the inner side of the upper molars, which in its complete development makes the upper molars three-lobed, as is seen in the typical Typotherium, representing the end of the series up in the Pampean formation. 'These relationships may be expressed graphically as in fig. 26.

\section{AdAPTATIONS}

Most striking of all the typothere peculiarities, is the development of the first upper and lower incisor in to permanently growing teeth, having the enamel reduced to the anterior side only, making thus a self-sharpening tooth similar to that of rodents. Such teeth are characteristic of gnawing forms and would indicate that the form lived, in at least a considerable part, on bark and twigs. In the eating of such food and breaking up the wood cells for the contained protoplasm and starch, an immense amount of chewing is involved, followed by a rapid wear of the molars. This is met, as is characteristic in rodents and grass eaters, by the development of first high-crowned, then permanently growing molars. In acquiring the permanently growing tooth, some of the irregularities of the crown are lost, others which are deep-seated enough to affect the tooth even to the root are maintained, so that especially the external and internal infoldings become a persistent part of the tooth, having been impressed into the dental papilla. A further supplement to the resistant character of the teeth is seen in the development, in the most advanced types, of a cement layer on the outside of the molars, a feature apparently also a part of permanently growing roots.

The feet are generally those of a running type, but a single phylum has acquired the hopping habit.

The above features seem to indicate a more special adaptation than grass feeding. From the aspect of the 
whole Deseado fauna, we would seem to be dealing with the inhabitants of an arid area, where bushes have, in part at least, replaced the grass. The typothere's seem to me to represent a part of the fauna which lived hy gnawing the bark and eating the twigs and leaves of bushes. This does not preclude the eating of grass also, but I do not see how they would have developed all their peculiarities by eating grass alone. The rodents are of such insignificant size that they could hardly have monopolized this food supply, and the typotheres seem to have adjusted themselves to, and occupied the place of rabhits on our western plains; but went even farther in developing in great numbers and varieties.

\section{Systematic Descriptions}

\section{Archaeohyracidae Ameghino}

This family is differentiated by the presence of enamel on all sides of the first incisor, by the unreduced condition of the lateral incisors, and by the small bulla of the mastoid. These are primitive features. Ameghino considered this family to belong to the hyracoids; hut, as explained earlier, I believe them to be true Typotheriu, though less specialized than the other families.

\section{Archaeohyrax Ameghino}

Archaeohyrax Amegh., 1897, Bol. Inst. Geog. Argen., t. 18, p. 43I .

This interesting genus is known by a complete skull found by Ameghino and of which we found no duplicates. I insert a reproduction of the side view of the skull, and the dentition is shown in fig. 24 a, and fig. 25 a. The dental formula is $\frac{1+3}{3+3}$. Incisor $\mathrm{I}$ is a little larger than the other incisors. Each upper molar has a vertical groove near the anterior external margin. In each upper premolar (after the first) and molar, there is a central pit surrounded 
by enamel, which is opposite the internal inflexion, and in a young individual, is presumably connected with the fold. In the same way, the last three lower premolars and the lower molars each have an internal pit, adjacent to the external inflexion. With advanced age all the teeth show closed roots, another primitive feature. In spite of the closed roots, the full dentition, and the enamel on the incisor; and on account of the deep inflexions and the isolated pits, I consider this genus a specialized side line, retaining many primitive features, and expect to find the

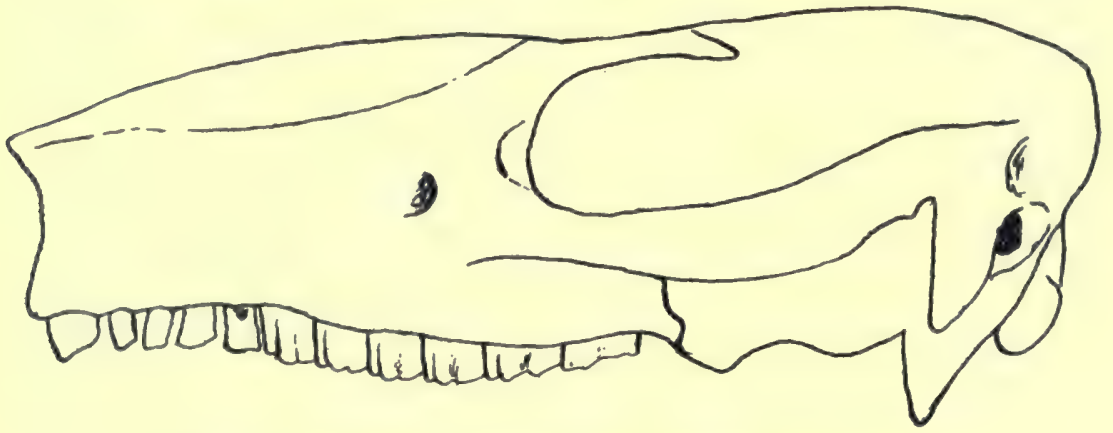

Fig. 27. Archaeohyrax patagonicus, after Ameghino-natural size.

ancestor of the typotheres in some one of the related Casamayor genera.

Ameghino described three species, A. patagonicus, which we have figured, and which has a length of $84 \mathrm{~mm}$. from inc. I to m. 3 in both the upper and lower dentitions; $A$. propheticus, of the same size, but with the dental series closed; and $A$. concentricus of larger size, the three lower molars having a length of $38 \mathrm{~mm}$.

\section{Plagiarthrus Ameghino}

Plagiarthrus Amegh., 1897, Bol. Inst. Geog. Argen., t. 18, p. 436.

This genus is known only by the lower premolars and molars, which are permanently growing teeth, composed of two subcylindrical cylinders almost entirely separated 
hy the external and internal folds which almont meet in the median line. On the outside, each teroth is craterl with a layer of cement. When better known it may prove that this genus, so specialized in the character of the teeth, does not belong in this family.

\section{Plagiarthrus clivus Ameghino}

P. clivus Amegh., 1897, Bol. Inst. Gcog. Argen., t. 18, P. 4.36.

This species is represented by a single specimen from the Chico del Chubut, west of Puerto Visser, which preserves pm. 3 and $t$ and the molars. The characters of this, the type species, are those of the genus. Fir. 28. Left lower premolars 3 and The total length of the five teeth is 4 and molars $1-3-$ natural size. $36 \mathrm{~mm}$., and fig. 28 shows in natural size the various individual teeth.

Hegetotheriidae Ameghinn

This family includes a large variety of forms from the formations from the Deseado up to the Mt. Hermosa, hut all agree in having the first upper and the first two lower incisors cnlarged into strong gnawing teeth; in the reduction or absence of in. 3, the canine, and premolar $\mathrm{I}$ of the upper and lower dentitions; in having the external fare of the upper molars not inflexed: in lewer molar 3 being threelobed; and in the hulla heing inflated and hollew. There are in the family two series of forms, at least, the one leading to the runing Hegetotherium, the other to the hopping Pachyrukhos, and the very little known form Phunophilus which may fit into one of the other series when better known.

In the Deseado the following genera are assigned to the family.

Prohegetotherium, like IIegetotherium, except that the last premolar and the molars have a vertical furrow near the external anterior margin. 
Prosotherium, $\frac{1043}{2043}$, upper inc. 2 and 3 and lower inc. 3 restigal, upper pms. not molariform, molars with a deep internal fold.

Propachyrucos, $\overline{3+43}$, lower jaw only, similar to $P a$ chyrukhos but have inc. 3 , the canine, and pm. I present and only a little reduced.

Phunophilus, upper molars only, but peculiar in having a strong external medial column.

\section{Prohegetotherium Ameghino}

Prohegetotherium Amegh., I897, Bol. Inst. Geog. Argen., t. 18, p. 424.

This little known genus is characterized by the upper molars having an external furrow near the anterior margin of the tonth. (Otherwise it is similar to IIegetotherium. Ameghino described a species where the external surface of the bones was sculptured "like reptiles." I do not see how, with the arrangement of the muscles usual to mammals, the sculpture could be similar to that of reptiles, and feel that this is due to conditions of weathering. We did not find this species, but did find a form which resembled it in general, but differed in being smaller and with the external furrow less developed.

\section{Prohegetotherium sculptum Ameghino}

P. sculptum Amegh., 1897, Bol. Inst. Geog. Argen., t. 1 8, p. 424.

This species is characterized by the deep external furrow on the upper molars. The measure given is $34 \mathrm{~mm}$. for the length of the three upper molars.

\section{Prohegetotherium shumwayi sp. nov.}

Founded on a portion of the right maxilla, carrying pm.

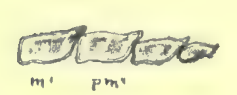

Fig. 20. H. Shumwayi

-natural size. 2 to 4 and $\mathrm{m}$. I, found on the Chico del Chubut, west of Puerto Visser, by Waldo Shumway.

The teeth are simple, with but a shallow ixternal furrow near the anterior margin of the premolars 
and molar. A film of cement covers each tooth and extends to the top of the crown. The form is smaller than P. sculptum.

\section{MEASI'REMENTS}

Upper premolar 3 , length $6 \mathrm{~mm}$., width $3^{\frac{1}{4}} \mathrm{~mm}$.

Upper premolar 4 , length $7 \mathrm{~mm}$., width $3 \frac{1}{2} \mathrm{~mm}$.

Upper molar $\quad \mathrm{I}$, length $7 \mathrm{~mm}$., width $3 \frac{1}{2} \mathrm{~mm}$.

\section{Prosotherium Ameghino}

Prosotherium Amegh., 1897, Bol. Inst. Geog. Argen., t. 18, p. 426.

In founding this genus. Ameghino says that lower pm. I is lacking, but our specimens show it present as a vestige, and also show no trace of lower inc. 3 against which. Imeghino puts a question mark. making the formula $\frac{1}{2}: \frac{1}{2}$ as given above. The upper molars are similar to those of Pachyrukhos except that they have an inner fold which has been lost in Pachyrukhos. The premolars are unlike the molars. Lower molar 3 is three-lobed. The description of the skeleton is given under the specific description of $P$. garsoni, and this shows a remarkable resemblane to the skeleton of Pachyrukhos, throughout, so that I have no, doubt but that Prosotherium is the ancestor of Pachyrukhos. the changes in the teeth proceeding in the line of simplification which seems to be general in this order, and is in general characteristic of forms in which the teeth hecome. rootless.

Ameghino described four species, $P$. garzoni, $P$. triangulidens, $P$. robustum, and $P$. quartum, the last two of which differ so little from $P$. triangulidens, that I can not consider them as independent species.

\section{Prosotherium garzoni Ameghino}

P. garzoni, Amegh., 1897, Bol. Inst. Geog. Argen., t. I8, p. 426.

This, the most abundant species of typotheres, occurs in our collection from the Chico del chubut, west of I'uerto 
Visser, fifteen times; and in one case the major part of a skeleton was found, consisting of the skull and jaws, vertebrae of each type, ribs, most of the fore limb, the pelvis and a hind limb.

The animal as a whole is smaller than $P$. triangulidens by about $12 \%$, and is of lighter build. The skull is rela-
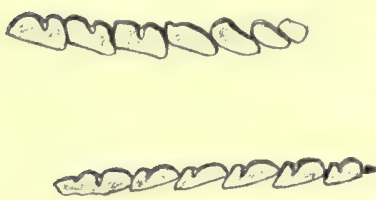

$D$ tively light and narrow, especially in the rear, where the swollen hollow capsules of the squamosum bones come within ten millimeters of meeting medianly, whereas, in other species, they are

Fig. 30. Left upper dentition; left lower dentitionnatural size.

twice as far apart. These hollow capsules are in this species the most marked, and in this genus even more developed than in Pachyrukhos. The lachrymal bone is larger externally than usual, the lachrymal duct opening about four millimeters in front of the margin of the orbit, and continuing to the margin by an open groove. In $P$. triangulidens, the duct is inside the orbit. The heavy maxilla makes a strong process for the zygomatic arch, extending fully half way back along this arch. 'The short, hut fairly stout jugale has but a short contact with the maxilla.

In the dentition, the premolar and molar teeth are covered with a thin film of cement, which is thicker on the outside of the upper teeth and on the inner side of the lower teeth. On the opposite sides of these teeth this film is so thin that it is often in part worn off.

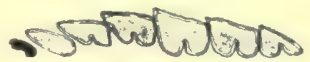

Specimen 3083 preserves three of Fig. 3r. I eft upper dentithe deciduous premolars. Pm. 2 is uous premolars.

simple and could readily be taken for the corresponding jermanent premolar, except that it is, as are all the deciduous premolars, rooted. Deciduous premolars 3 and 4 , on 
the other hand, have a marked inflexion on the inner side, giving them the appearance of permanent molars. The series measures $31 \mathrm{~mm}$. of which the deridunus premolars occupy just half.

The mandible is deep, especially the posterior portion; has a very slender coronoid process; and a slightly rounded articular condyle, which is a little longer than wide, so

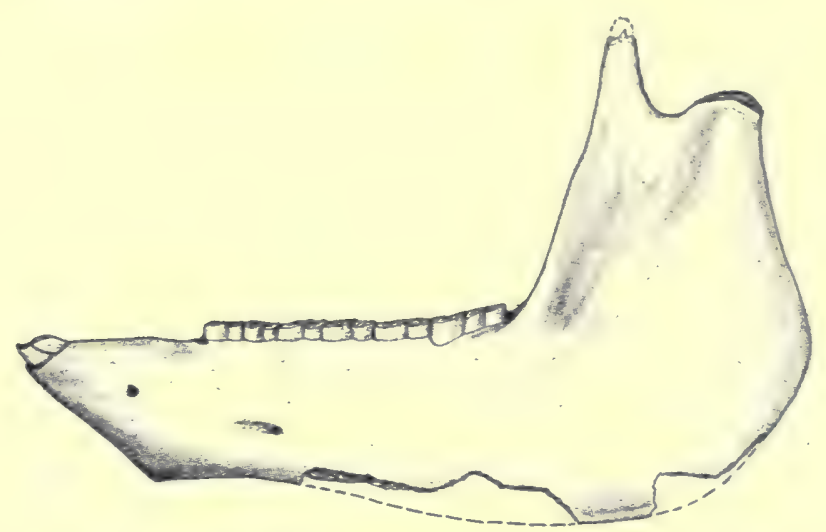

Fig. 32. Left mandible-natural size.

that it would seem to allow a forward and hackward motion of the lower jaw.

The vertebrae are considerably crushed, but have in each case the characteristics of the corresponding vertebra of Pachyrukhos.

Of the humerus, the head and distal ends are preserved. indicating a rather long and slender bone, very like that of Pachyrukhos. Alout three-fourths of the ulna is present. and it is also long and slender, with a wide articular facet for the radius, which is entirely separate from that for the humerus. Two metacarpals show the same elongation of the limb, and the two phalange's preserved indicate a small front foot. 


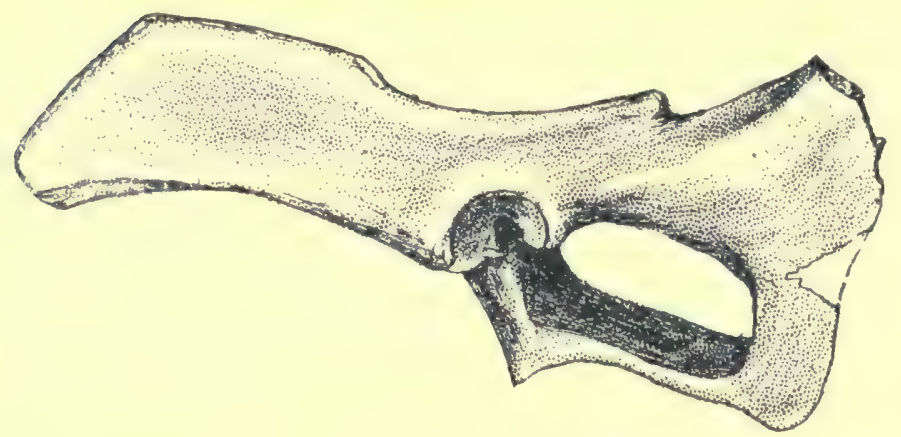

Fig. 33. Left side of pelvis-natural size.

The pelvis is elongated, slender and lightly built, indicating the same characteristics in the whole hind limb. The fomur has a small rounded head on a well marked neck. It is cxcessively long, longer than that of Pachyrukhos, and also

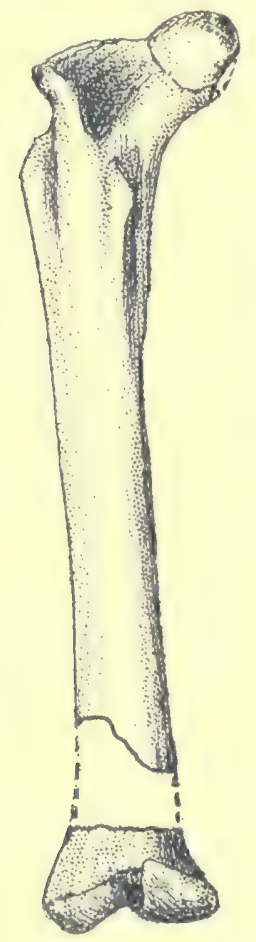

liig. 3.4. Leeft femutnatural size.

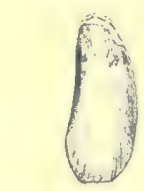

Fig. 35. Patellanatural size.

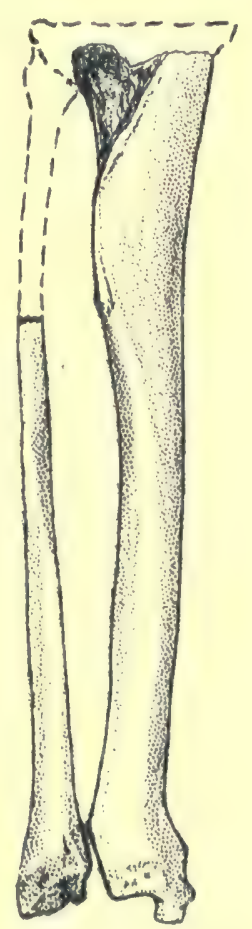

Fig. 36. Tibia and fibula - natural size. 
straighter. It is further distinguished hy the third trochanter being swung onto the laack side of the bone. The tibia and fibula are separate throughout their entire length, in which this genus is in strong contrast to Pachyrukhos, where these two bones are fused, both distally and proximally.

The astragulus is also quite characteristic, the trochlear surface being entirely on the dorsal surface, and the condylar ridges being relatively low and flat. This trochlear surface is far from being symmetrical, the inner ridge being much flatter and lower

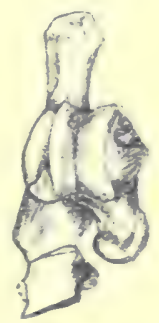

Fig. 37. Calcaneum.

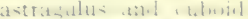

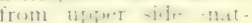
ural size.

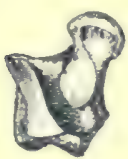

than the outer. The head of the astragulus is rounded, on a long neck, and directed obliquely inward. The fibular facet for the fibula is crescent-shaped and vertical Fig.38. Astragulusfrom except that the small below-natural size. proximal end of the crescent flares out. The outline of the sustentacular facet is that of an acute ovoid. and is situated mostly on the neck of this bone. The ectal facet is roughly rectangular in outline, strongly concave, and is separated from the sustentacular facet by a deep groove.

The calcaneum is of moderate size, has a narrow fibular facet, a broad ectal facet, and a moderately large sustentacular one. The facet for the cuboid is slightly concave, and occupies the whole of the distal and of the calcaneum.

The metatarsals are moderately long

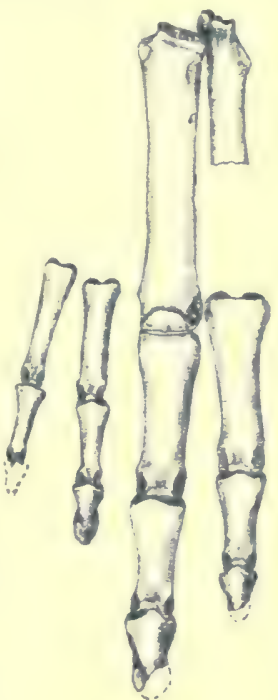
and rather heary, not quite as long Fig. 39. Right foot-natural and slender as those of Pachyrukhos. size. The phalanges are alise shorter and slightly heavier than those of Puchyrukhos. Me found four proximal and four of 
the second series, all associated, which probably indicates the full number of the toes. The ungual phalanges are proximally narrow and high, then expand toward the tip, developing into marginal expansions. There is but a trace of a cleft in the end of these ungual phalanges.

\section{MEASUREMENTS}

Skull, greatest length

$99 \mathrm{~mm}$.

Upper dentition, length inc. I to $\mathrm{m} .3$

$55 \mathrm{~mm}$.

Upper dentition, length pm. I to m. 3

$3 \mathrm{Imm}$.

Upper dentition, incisor $I$, width

$6 \frac{1}{2} \mathrm{~mm}$.

Upper dentition, molar I, length

$6 \mathrm{~mm}$.

Upper dentition, molar, width

Mandible, greatest length

$4 \frac{1}{2} \mathrm{~mm}$.

Lower dentition, length inc. I to $\mathrm{m} \cdot 3$

$82 \mathrm{~mm}$.

Lower dentition, length pm. I to m. 3

$53 \mathrm{~mm}$.

Lower dentition, molar I, length

Lower dentition, molar, width

Third metacarpus, greatest length

Pelvis, length front to back

Femur, greatest length (computed)

Femur, diameter of middle of shaft

$32 \mathrm{~mm}$.

$6 \frac{1}{2} \mathrm{~mm}$.

Tibia, greatest length

Astragulus, length

Astragulus, width

Calcaneum, length

Metatarsus III, length

First phalanx of digit III, length

Ungual palanx of digit III, length

$3 \mathrm{~mm}$.

$28 \mathrm{~mm}$.

$83 \mathrm{~mm}$.

$93 \mathrm{~mm}$.

$9 \mathrm{~mm}$.

go $\mathrm{mm}$.

$14 \mathrm{~mm}$.

I $\mathrm{mm}$.

$25^{\frac{1}{2}} \mathrm{~mm}$.

$32 \mathrm{~mm}$.

I2 $\mathrm{mm}$.

$9 \mathrm{~mm}$.

To make the similarity of Prosotherium with Pachyrukhos clearer, I have restored Prosotherium, figure 40, from which it will be seen that this genus is also a hopping form with a plantigrade hind foot and a semidigitigrade front foot. In general it compares very closely with Pachyrukhos, but the limbs are shorter and the grade of specialization is not quite as high. It is, however, very evidently the ancestor of Pachyrukhos. 


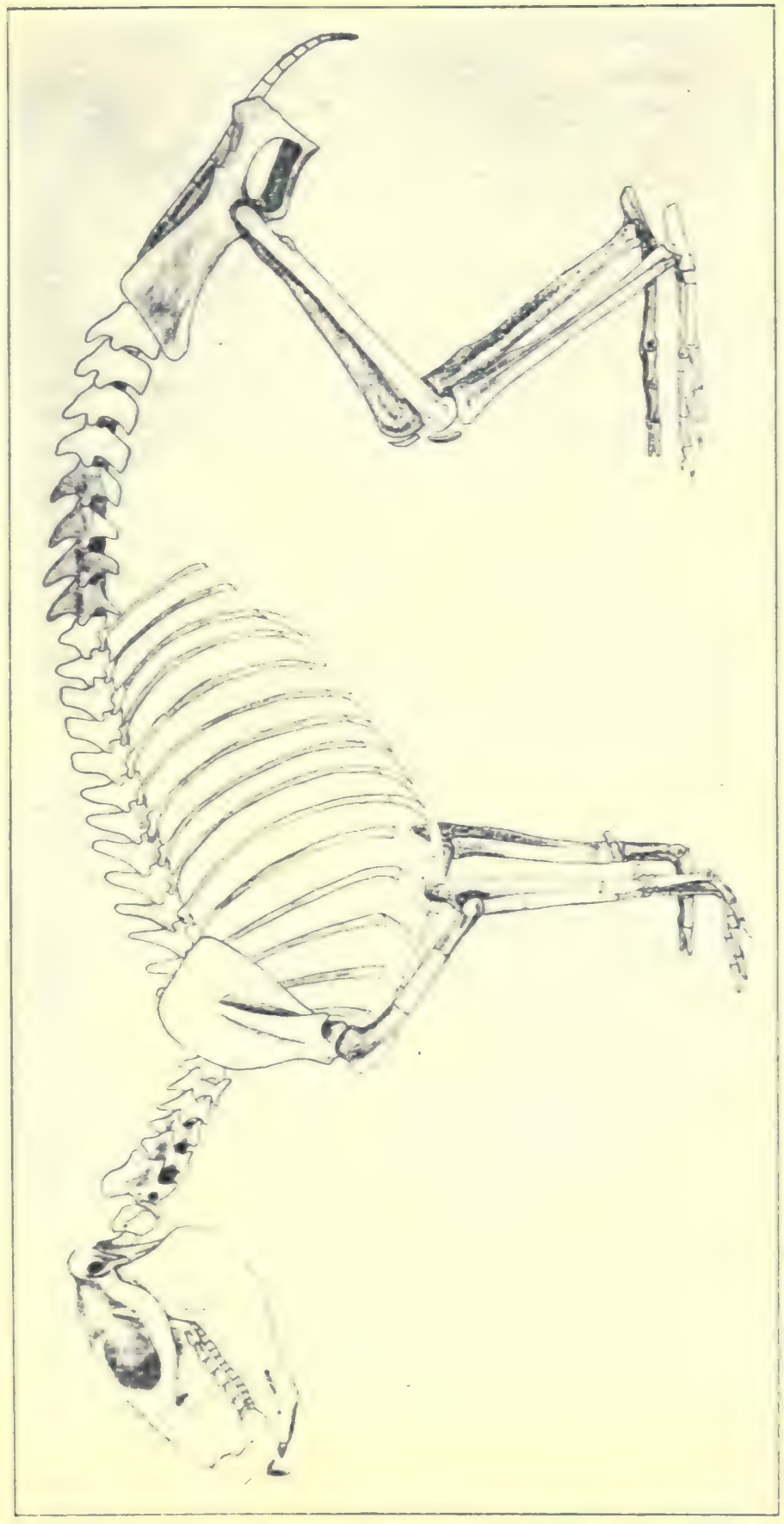

 


\section{Prosotherium triangulidens Ameghino}

P. triangulidens Amegh., 1897, Bol, Inst. Geog. Argen., t. I8, p. 427.

P. robustum, Amegh., 1897, Bol. Inst. Geog. Argen., t. I8, p. 427.

P. quartum Amegh., 1901, Bol. Acad. Nac. Cienc. Cordoba, t. 16, p. 37 I.

This species is similar to $P$. garzoni except for size, the forms running about $12 \%$ larger, and being heavier built. In this same line the upper and lower molars are relatively wider and heavier. The top of the skull also is wider. I have drawn carcfully the skull and dentition so that the detail can be seen from the figures. Beside triangulidens, Ameghino described $P$. robustum, which, as far as I can sce, differs only in being about $5 \%$ larger, which is well within individual rariation, so I have considered it as a synonym. The same is the case with $P$. quartum, which Ameghino distinguishes as being about the size of $P$. robustum, and having lower pm. I present. The latter character we found also characteristic of $P$. garzoni, so only size remains and I do not consider less than $10 \%$ enough by itself to make a species.

\section{Measurements}

Skull, length

Upper dentition, length inc. I to m. 3

I Io $\mathrm{mm}$.

Upper dentition, length pm. I to m. 3

$57 \mathrm{~mm}$.

Upper dentition, incisor $\mathbf{I}$, width

$35 \mathrm{~mm}$.

Upper dentition, molar I, width

$8 \mathrm{~mm}$.

$4 \frac{1}{2} \mathrm{~mm}$.

Six specimens from Chico del Chubut

\section{Propachyrucos Ameghino}

Propachyrucos Amegh., I 897, Bol. Inst. Geog. Argen. t. I8, p. 425.

The genus is based on lower jaws, in which the characters of the premolars, the molars and the first two incisors, resemble those of Pachyrukhos; but in this genus the third incisor, the canine, and the first premolar are retained and but little reduced. Ameghino has described two species, $P$. smithwoodwardi, and $P$. aequilatus. 

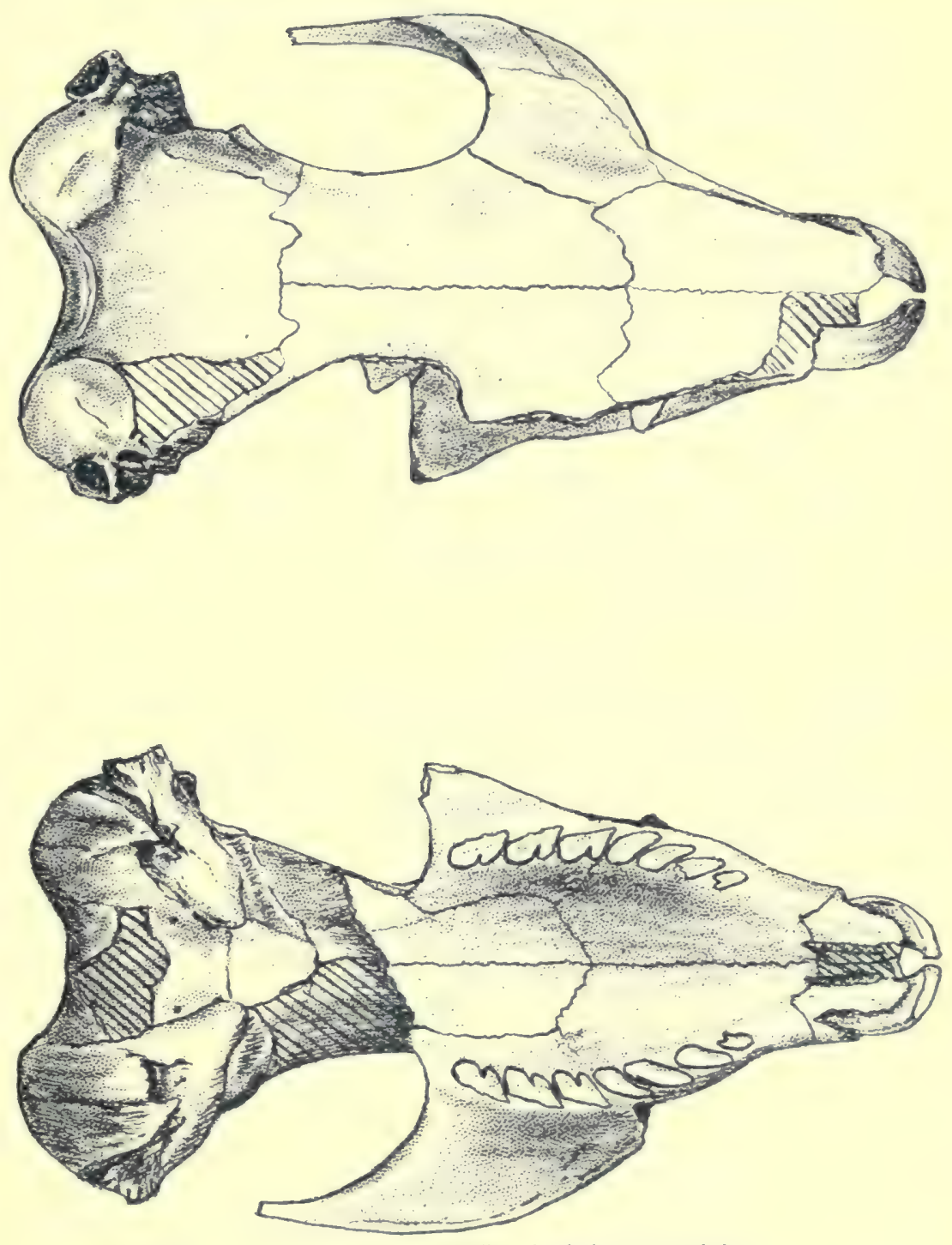

Fig. 4r. Top view of the skull, palatal view-natural size 


\section{Propachyrucos smithwoodwardi Ameghino}

P. smithwoodwardi, Amegh., I897, Bol. Inst. Geog. Argen., t. 18, p. 425.

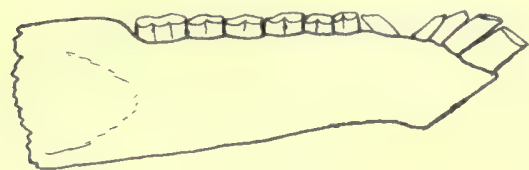

Fig. 42. P. smithwoodwardi after Ameghino, right mandible-natural size.

We did not find this species, but I reproduce Ameghino's figure of it, natural size. The length of the dentition from inc. I to $\mathrm{m} .3$ is $4 \mathrm{I} \mathrm{mm}$., height of mandible under $\mathrm{m}$. $\mathrm{I}$ is $\mathrm{I} 2 \mathrm{~mm}$.

\section{Propachyrucos aequilatus Ameghino}

P. aequilatus, Amegh., I9or, Bol. Acad. Nac. Cienc, Cordoba, t. I6, p. 37 r.

This species is based on the anterior lobe of each lower molar, being longer than the posterior. In size, molars I to .3 measure $24 \mathrm{~mm}^{*}$

\section{Phanophilus Ameghino}

Panophilus, Amegh., I903, Anal. Soc. Cienc., Argen., t. 56, p. 202.

This genus is based on isolated upper molars, characterized as similar to Protypotherium, but having a pronounced median vertical column, instead of a groove on the external face of the upper molars, a character unique among typotheres. The position of the genus with this scant information is uncertain. One species is described, P. dorsatus.

\section{Phanophilus dorsatus Ameghino}

P. dorsatus, Amegh,, loc. cit. p. 202.

In our collection, two isolated upper molars of this unusual form occur, corresponding in size and pattern to the one described by Ameghino. The external column, as

* P. crassus has been described, (loc. cit., p. 425,) based on pm. 2 and 3 , of larger size than either of the foregoing but I do not think that the genus can be determined on so small a fragment. 
seen by fig. 42 , is narrow and high. A single tooth measures $5: 2 \mathrm{~mm}$. from front to back. and $3 \frac{3}{4} \mathrm{~mm}$. in width.

Specimen $3 \mathrm{I}_{4} 2$ gen. and sp. ? This specimen is the mandible with the Fig. A3. Fiternal milk dentition. The molars present suggest natural size.

Prosotherium triungulidens, hut inc. 3 and the canine are present, and the first two incisors are not enlargerl, so it would seem to represent a genus which I have not been able to identify. Molar $I$ is hilobed and similar to that of Prosotherium. The deciduen- premelars are all present, all

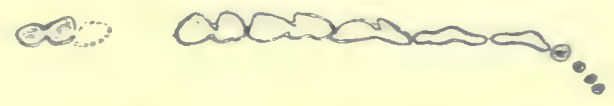

Fig. 44. Milk dentition, genus and species?-natural size.

rooted, and all remarkalse for their great antero-posterior elongation. Roots of the incisors and canine are present. that of the canine being the largest, and those of the incisor: being about equal in size. This would suggest such a form as Protypotherium, were this genus represented in the Deseaclo beds.

\section{Interatheriidae}

The family is characterized by the incisors not being enlarged, by upper and lower premolars and molars being inflexed on both the inner and out sides, and by the inflated mastoid bulla being filled with cancellous tisurue. The only genus referable to this family, from the I)eseado beds, is Archaeophylus.

\section{Archaeophylus Ameghino}

Archaeophylus Amegh., 1897, Bol. Inst. Geog. Argen., t. I8, p. 423.

The genus is hased on a skull which preserved most of the upper dentition except the incisors, and which show: the characteristics of the family in their inception. 


\section{Archaeophylus patrius Ameghino}

A. patrius Amegh, loc, cit.

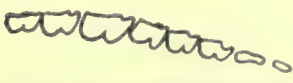

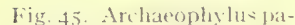
trius afte's Ameghino, right upper dentition-natural size.

We found no specimen of this interesting type, but I give a diagram of Ameghino's type, which shows the characteristics of the species and genus. The length of the premolar-molar series is $27 \mathrm{~mm}$.

\section{Eutrachytheridae Ameghino}

The family consists of larger forms than the other families, and is characterized by the upper molars having the inflexion bifurcated, so that the teeth are at least incipiently three-lobed. I would place in the family the genera, Eutrachytherus, Argyrohyrax, and Isopoedrium.

\section{Eutrachytherus Ameghino}

Trachytherus Amegh., I889, Act. Acad. Nac, Cienc. Cordoba, t. VI, p. 918.

Trachytherus Amegh., I 895, Bol. Inst. Geog. Argen., t. I 5, p. 623.

Eutrachytherus Amegh., 1897, Bol. Inst. Geog. Argen., t. 18, p. 429.

This genus was first called Trachytherus, and when this was found to be preoccupied, changed to Eutrachytherus.

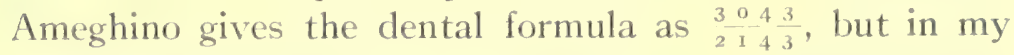
specimen which is a comparatively young individual, I find a small alveolus for the upper canine, which modifies the formula to $-\frac{3}{2}+\frac{3}{1}+3^{\circ}$. In the first upper dentition found, incisors 2 and 3 were represented by alveoli only, but our specimen shows these teeth, and we find that they have enamel only on the outer face, making this genus more specialized in this respect than any of the other typotheres. The upper molars have the deep inner inflexion bifurcated, which makes the tooth three-lobed, a character which grows more marked the older the individual is. The premaxillae are high and bring the snout well forward. The nasals are lacking, but the bounding bones show them to 
have heen unusually hroal and flat. The maxilla extends up to the nasals, and buend = the lower border of the orbit. and projects hackward in a heary orerhanging zygomatic process. The lachrymal bone is large externally, with a large but low lachrymal tubercle just below which is found the lachrymal duct, opening just in front of the margin of the orbit. The frontals are short and wide, extending outwarl over the orbit in a strong postorbital process which bounds half of the rear of the orbit. The parietals, meeting mertianly, rise in a strong sagittal crest. Infortunately the hack part of the cranium is lacking.

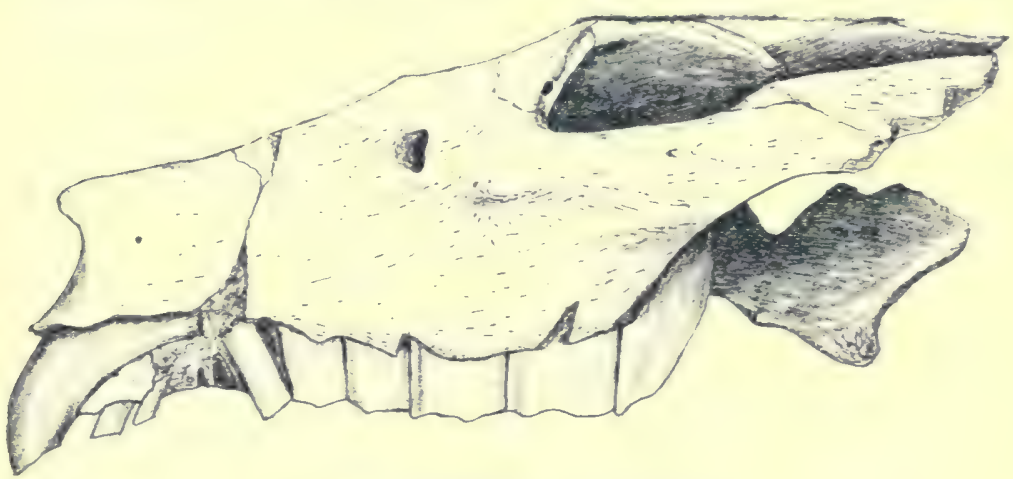

Fig. 46. E. spegazzinianus $-1 / 2$ natural size.

From another specimen, which contained the brain cast. it is clear that the bulla was much inflated and hollow. and that there was an inflation in the upper part of the squamosum, as in Prosotherium, etc.

One specimen with the facial portion badly weathered, but retaining enough to identify the species as Li. spegarzinianus, preserved the brain case, so that it could be prepared out.

The most striking feature of this brain is its relatively large size, E. spegazzinianus being an animal about the size of a sheep, and the brain is as large as that of the sheep, which is in strong contrast to what would be expected of an Oligocene form. Compared with the herbiv- 
orous Oligocene oreodont, Eucrotaphus, an animal of approximately the same size, this brain is half again as large in every way. A second striking feature is the short compact character of the brain, the forebrain extending only a short distance in front of the exit of the optic nerves, and extending backward so as to cover most all of the cerebellum. Thirdly, the cerebral surface is considerably convoluted, comparable to the convolution of a pig's brain. These features would indicate a specialization of the nervous system, approximating that of the skeleton, and would indicate that this group had advanced in intelligence and activity beyond the grade of nervous development which is apparent in the contemporaries of the Typotheria.

The relatively small olfactory lobes are entirely beneath the frontal lobes and are seen only on the side view, but as there is a large hippocampal lobe behind them, it would only seem proper to attribute to these animals a welldeveloped sense of smell. The frontal lobes are unexpectelly large, and are not clearly bounded off from the parictal lobes. The occipital lobes are also well developed and make a large portion of the backward extension of the cerebrum. The large size of this area, together with the fact that the optic nerves are large, indicates a good visual development. The temporal lobes are also large and extend well down on either side. And, finally, below all the others, come the swollen hipporampal lobes which complete this large cerebrum.

The cerebellum is small having neither considerable width or height, and being overlapped by the cerebrum. The optic nerves are represented by large projections leaving the twixt-brain well forward under the forebrain. The medulla is not clearly marked except to show that it, too, was of fair size.

Just behind the hippocampal lobes, and connecting with the cerebellum appear two striking projections. These 

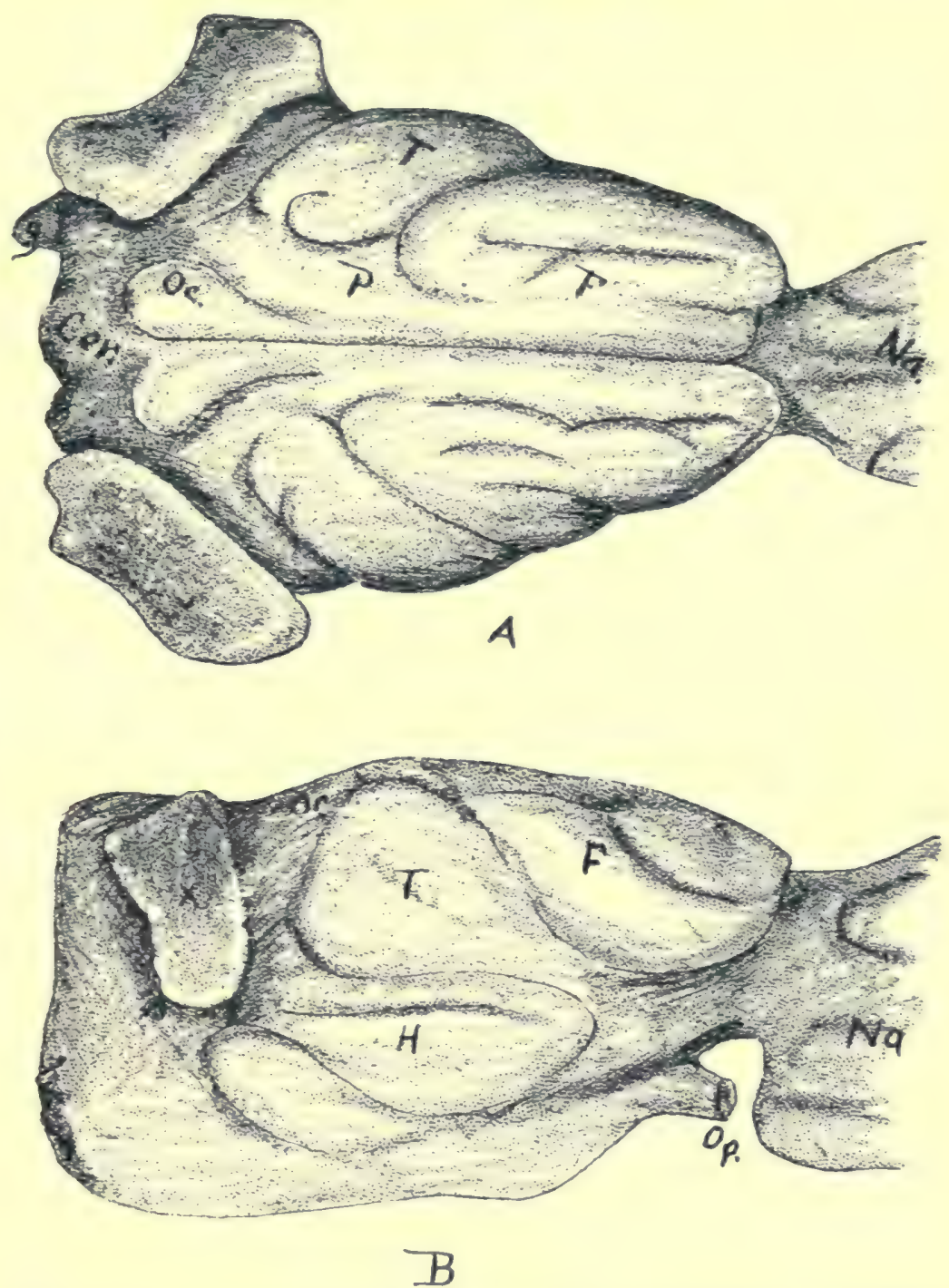

Fig. 47. Cast of the brain; A, from above; $B$. from the side-natural size. Crr, cerebellum: $F$, frontal lobe; $H$, hippocampal tobe; ()$_{c l}$, occipital lobe: $O p$, optic nerve; $T$, temporal lobe; $x$, cast of cavity in squamosal bone; . $a$, case of interior of nasal cavity.

represent the two large cavities in the upper part of the squamosum which are so characteristic of typotheres. The two large cavities clearly opened into the brain case 
by a broad connection which is especially wide at the lower ends. I find no traces of a connection with the bulla as described by Sinclair for Pachyrukhos. Further down are two small knobs apparently also representing cavities in the squamosum, and also connected with the brain case. In considering the brain these should be overlooked; but they doubtless represent some nervous function to which I have as yet no clue.

Ameghino considered that Eutrachytherus was the connecting link between Archaeohyrax and Typotherium. I feel that this genus is too highly specialized to be a connecting form, though it doubtless belongs to the series which ends in Typotherium; and such a form as Argyrohyrax is more likely to be the really ancestral form.

Two species are described, E. spegazzinianus, and E. conturbatus, which is about $15 \%$ smaller. Our collection offers a third species, $E$. grandis, which is nearly $50 \%$ larger than the first named species.

\section{Eutrachytherus spegazzinianus Ameghino}

Trachytherus spegazzinianus Amegh., 1889, Act. Acad. Nac. Cienc. Cordoba, t. VI, p. 919.

Trachy therus spegazzinianus Lydekker, 1894, Anal. Mus. La Plata, pt. 3, p. 2. Trachytherus spegazzinianus Amegh., I 895, Bol. Inst. Geog. Argen., t. 15, p. 622.

Eutrachytherus spegazzinianus Amegh., 1897, Bol. Inst. Geog. Argen., t. 18, p. 428 .

This species was founded on the anterior part of a skull with the full upper dentition. My specimen differs from Ameghino's in having a tiny alveolus for the upper canine, the difference being due to my specimen being younger.

The upper dentition is very characteristic. Incisor I is a powerful, deep-set, curved gnawing tooth, with a heavy layer of enamel on the anterior face, and none on the other sides; and is moderately beveled in the rear as a result of wear. The second and third incisors are much smaller, each having enamel on the outer face only, and 


\section{Eutrachytherus conturbatus Ameghino}

Trachytherus conturbatus Amegh., 1895, Bol. Inst. (icog. Argen., t. I 5, p. 623. Eutrachytherus conturbatus Amegh., 1897, Bol. Inst. Geog. Argen., t. 18, p.

429.

This species is founded on upper teeth, which are said to be relatively smaller anteriorly, and actually smaller throughout, hy about $15 \%$ than are those of the preceding species. Molar I measures $17 \mathrm{~mm}$. long by $9 \mathrm{~mm}$. wide.

\section{Eutrachytherus grandis sp. nov.}

This species is based on upper molars I and 2 of the left side, from the I)eseado beds, of the Chico del ('hubut,

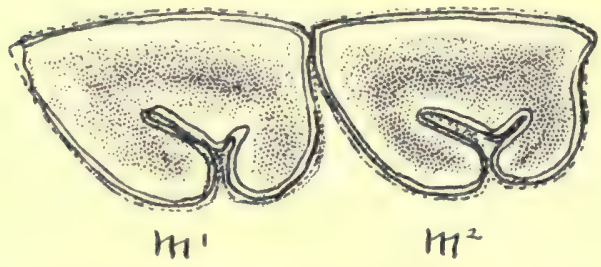

Fig. 49. E. grandis, molars of the left side-natural size. west of Puerto Visser. The teeth are typically those of the genus and differ only from other species in their large size, being some $50 \%$ larger than the corresponding teeth of $E$. spegazzinianus. Each is covered with a layer of fully half a millimeter of cement.

\section{Measurements}

Upper molar I, length $29 \mathrm{~mm}$, width $2 \mathrm{I} \mathrm{mm}$. Upper molar 2, length $30 \frac{1}{2} \mathrm{~mm}$., width $18 \mathrm{~mm}$.

\section{Argyrohyrax Ameghino}

Argyrohyrax Amegh., I 897, Bol. Inst. Geog. Argen., t. 18, p. 435.

The genus is distinguished by the full dentition in closed series, and by the upper molars having a deep internal inflexion which is hifurcated, making the teeth at least incipiently three-lobed. Incisor I is relatively somewhat wider than in the preceding genus. It seems to me that it is from such a genus that Typotherium arose, by the reluction of the lateral incisors, the canine, and the first 
two premolars, and hy the increase of the hifurcated internal fold. Three species have been describer, A. proar'us, the type species, A. acuticostatus, of a little smaller size, and $A$. proavunculus of still smaller size.

\section{Argyrohyrax proavus Ameghino}

A. proavus Amegh., 1897, Bol. Inst. Geog. Argen., t. I8, p. 436.

This species occurs three times in the Amberst collertion. The best specimen has pm. I, 3, 4, and $\mathrm{m}$. I and 2 of the upper jaw. The species is characterized by a narrow furrow near the anterior external margin of the premolars and molars; and by pm. 3 and $t$ and the molars

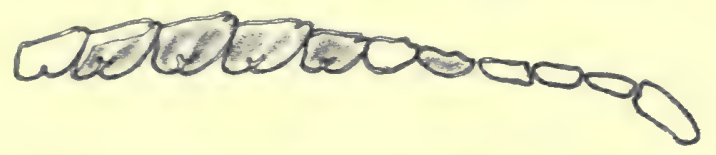

Fig. 5o. Right upper dentition, the outline tecth after Ameghinonatural size.

having a de'ep internal bifurcated inflexion, which tends to make these teeth three-lobed.

The genus is known only by the upper dentition, and while I did not find any associated lower teeth, I believe that some one of the genera known only by the lower dentition, like Plagiarthrus, is that lower dentition.

MEASTREMENTS

$\begin{array}{crl}\text { Lpper dentition, length inc. I to m. 3 (@ Ameghino) } & \text { 7r } \mathrm{mm} \text {. } \\ \text { premolar I, length } 7 \mathrm{~mm} \text {., width } & 4 \mathrm{~mm} \text {. } \\ \text { premolar 3, length } 7 \mathrm{~mm} \text {., width } & 6 \mathrm{~mm} \text {. } \\ \text { premolar 4, length } 8 \mathrm{~mm} \text {., width } & 6 \mathrm{~mm} \text {. } \\ \text { molar I, length } 8 \mathrm{~mm} \text {, width } & 6 \frac{1}{2} \mathrm{~mm} \text {. }\end{array}$

\section{Argyrohyrax proavunculus Ameghino}

A. proavunculus Amegh., I 897, Bol. Inst. Geog. Argen., t. I8, p. 436.

The species is simply said to be much smaller than the preceding. which, by the measurements, would figure out ahout $27, \mathrm{c}$. The measurements given are pm. I to $\mathrm{m} .3$, $33 \mathrm{~mm}$. 


\section{Argyrohyrax acuticostatus Ameghino}

A. acuticostatus Amegh, 1901, Bol. Acad. Nac. Cienc. Cordoba, t. 16, p. 36 I.

This species is described as differing from $A$. proavus in being somewhat smaller, but I find it about the same size. The specific character is in the teeth being more compressed, and in the anterior vertical margin of the upper molars being developed in the form of a very salient crest.

\section{Isoproedrium Ameghino}

Proedrium Amegh., 1895, Bol. Inst. Cieog. Argen., t. 15, p. 623. Procdrium Amegh., I 897, Bol. Inst. Geog. Argen., t. 18, p. 43 I. Isoproedrium, Amegh, I903, Anal. Soc. Cient. Argen., t. 56, p. I8.

This genus is based on a toothless mandibular symphysis of large size, on which the second incisor is indicated as larger than the first. We found one lower jaw, which, though imperfect, confirms the above as a genus and adds the following for generic characters; premolars with a shallow inflexion on the inner and outer sides, the molars with a shallow inner, and a narrow deep outer inflexion, heavy layer of cement on the premolars and molars, cnamel recluced on the anterior internal, and the posterior internal corners of at least the premolars.

\section{Isoproedrium solitarium Ameghino}

loc. cit. above.

I have assigned the specimen shown in fig. $5 \mathrm{I}$ to this species. Alveoli of the first and second incisors show inc.
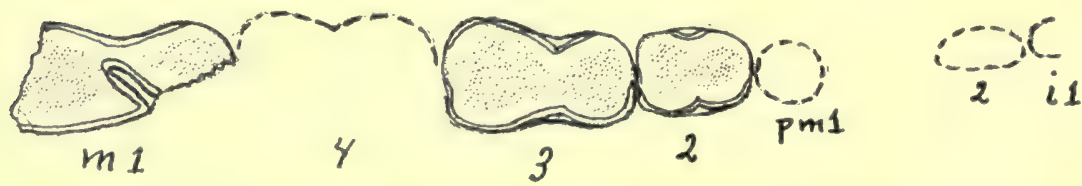

Fig. 51. Right mandible, dotted line indicated alveolus-natural size.

2 considerably larger than inc. I. About the third incisor and the canine my specimen shows nothing, being broken 
down in that region. Pm. I is represented ly a moderately large alveolus, $10 \mathrm{~mm}$. long. P'm. 2 is $1.3 \mathrm{~mm}$. long by io mm. wide, and slightly constricted medianly as far as the enamel is concerned, the furrow in either sicle being filled with rement. P'm. 3 is 18 mm. long by 12 wide and similar. There is only an alveolus for pm. 4, which is $23 \mathrm{~mm}$. long. M. I is incomplete, but was about $23 \mathrm{~mm}$. long by $10 \frac{1}{2} \mathrm{~mm}$. wide and is distinguished ly the deep outer inflexion. Each tooth present is covered with a heary layer of enamel nearly a millimeter thick: and each of the teeth is unique in that the enamel is wanting on the anterior internal and the posterior internal corners of the teeth. 


\section{CHAPTER VI}

\section{TOXODONTIA}

THE toxodonts of the Deseado are much more varied than those of the Santa Cruz, and less so than those of the Casamayor; the teeth less hypsodont than in the Santa Cruz, and more hypsodont than in the Casamayor; are smaller than those of the Santa Cruz, and larger than those from the Casamayor. It is a group of heavy, short-limbed, nonadaptive animals, which, as time and competition progressed, gradually diminished in numbers and variety.

The ancestral type must be sought in some such a form as IIenricosbornia, where the upper molars are brachydont, have the four primary cusps distinct, and the connecting crests of small size, and a cingulum moderately developed on the front and rear sides. Progress is in the line of enlarging the crests, so that, in the later forms, the two external cusps are united to make a wall; and the anterior external and the anterior internal cusps are united into the large anterior lobe; while the posterior external and the posterior internal cusps unite to make the posterior lobe. These may remain relatively simple as in Rhynchippidae*; or with this simple arrangement of the cusps, the cingulum may be developed into a platform around the anterior, inner, and posterior sides of the molars, as in the Isotemnidae; or, with relatively simple molars, the incisors may be specialized into caniniform-like teeth as in the Leontiniidae; or secondary processes (or cristae) may develop from the wall, making the complicated teeth characteristic: of Nesodontidae.

* I have abandoned the family term Notohippidae, as the genus used as a basis is very little known, and the forms Ameghino assigns to the family, to my mind, mostly belong with the Nesodontidae. 
For convenience in discussing the molifications of the toxodont tooth, I have, throughout, used the nomenclature illustrated in fig. 52, taking one of the most complicated to
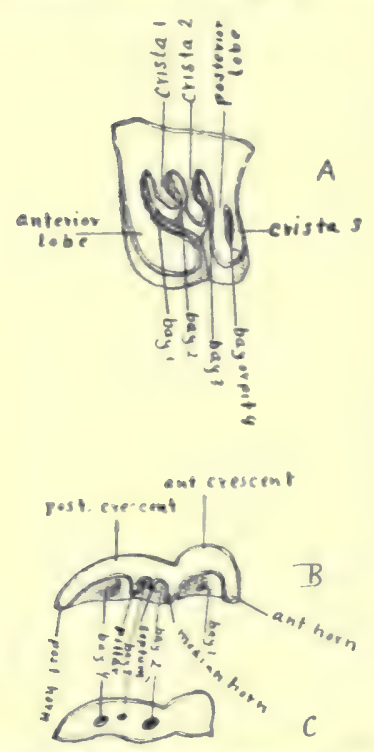

Fig. 52. A, ulver mulars of ('orssodun; $B$, lesuer molurs, semes whit worn-natural size. show the ultimate development. In the upper tooth there is, first, the external wall, from which springs the anterior lobe, always the larger lobe, and composed of the protocone and paracone of Osborn. In the rear is a smaller narrower posterior lobe, composed of the hypocone, the metacone, and the metaconule of Osborn. Between these is a large basin, which may be subdivided by two cristae into secondary bays, referred to as bays I, 2 and 3, while the cristae are in the same way referred to as cristae I and 2. In some genera, the cristae are entirely wanting, in others incipient. When fully developed, they are most marked in young individuals and, as the tooth is worn, appear progressively shorter. Behind the posterior lobe, there is a variable bay, number + which is bounded behind by crista 3, which is apparently a development of the posterior cingulum. This last crista and bay may or may not be present.

The lower molars of toxodonts are all on the same plan. each torth being composed of two crescents, the anterior and posterior. The ends of these crescents are referred to as the anterior, median and posterior horns. The bay in the anterior crescent is simple and usually disappears with the wear of the tooth without making a pit. In the centre of the posterior crescent is the pillar or posterior tubercle which Soott has found to be characteristic of these South American Ingulates. It is, to my mind, the same as the 
mesostylid of the Fâyum hyracoids. Between the pillar and the median horn, I find a narrow vertical ridge, which I have termed the septum; and which tends to unite with the pillar inclosing a small bay, usually seen in worn teeth as a pit. The bay between the septum and the median. horn is designated bay 2, and this quite generally appears in a worn tooth as a pit (2). The bay between the septum and pillar is designated bay 3 , and is usually seen as a tiny pit, which however does not extend as deep in to the crown as the other pits and is usually lost when the tooth is about half worn off. 'The bay between the pillar and the posterior horn is numbered 4, and is usually open, though in a worn tooth it also may appear as a pit. 'The effect of wear is shown by comparing $\mathrm{B}$ and ( $\mathrm{C}$ in fig. 52 , the latter being the same tooth sectioned a little below the middle. I find in studying a lower molar of Coresodon that bay 3 becomes a pit after some $6 \mathrm{~mm}$. are worn off, while bays 2 and 4 remain open until some $10 \mathrm{~mm}$. are worn off when they also become pits. Pit 3 will disappear when $12 \mathrm{~mm}$. are worn off, but pits 2 and 4 run to the base of the crown.

The various genera of the Toxodontia in the Deseado I would divide into four families as follows:

Rhynchippidae: molars brachydont, secondary cristae lacking or little developed, none of the incisors caniniform, limbs slender, feet digitigrade, digits $3-3$.

Leontinidae: molars brachydont, secondary cristae lacking or little developed, upper inc. 2 and lower inc. 3 developed into caniniform teeth, limbs heary, feet digitigrade, digits $3^{-3}$ (according to Gaudry).

Isotemnidae: molars brachydont, secondary cristae more or less developed, crowns contracted at the top, congulum more or less developed into a platform, skeleton unknown.

Nesodontidae: molars hypsodont, secondary cristae highly developed, upper inc. 2 and lower inc. 3 caniniform, limbs heavy, feet digitigrade, digits 3-3. 


\section{Rhynchippidae}

This family name is used for the three genera Rhynchippus, Morphippus, and Eurygeniops, which made up a part of Ameghino's family, Notohippidue. 'There forms I find much simpler than Coresodon, Interhippus. Stilhippus, and Vesohippus, which, hy their molars, whould be associated with Vesodontidue, unless it should prove that they did not have the incisors enlarged to caniniferm teeth, in which case another disposition will have to be made of them. Ameghino places the Rhynchippidat among his Hippoidea, leading to horses, but we found a nearly complete skeleton of Rhynchippus equimus which in all particulars is typically toxodont. In the Ieseacle we found fourteen specimens belonging to this family, and strangely enough they were all Rhynchippus, and all of the species $R$. equinus.

This family is distinguished by the brachydont, or nearly brachydont, molar teeth, being relatively simple, and the secondary cristae not being developed. 'The large basin in the upper premolars and molars is, therefore, not subdivided, but is deep, and rather narrow, usually appearing as an oblique pit in the centre of the crown. There is no enlargement of the incisors to make caniniform teeth. Both the upper incisors and the canine have in the crown a longitudinal groove, which on wear becomes a pit, and being shallow may disappear entirely. The lower teeth are those typical of all toxudonts. The feet are tridatyl, and compact.

The following three genera may be distinguisherl:

\begin{tabular}{|c|c|c|c|}
\hline & RHYNCHIPPTS & MIORPHIPPUS & ELRYGENIOPS \\
\hline \multirow{2}{*}{ Formula } & $31+3$ & $3 x+3$ & $31+3$ \\
\hline & $31+3$ & 3143 & $3 x+3$ \\
\hline Skull & moderately long muzzle & $\begin{array}{l}\text { short muzzle, with } \\
\text { slight constriction be- } \\
\text { hind canines }\end{array}$ & $\begin{array}{c}\text { short heavy muzzle, } \\
\text { with marked constric- } \\
\text { tion behind canines }\end{array}$ \\
\hline
\end{tabular}




\begin{tabular}{|c|c|c|c|}
\hline Lower incisors & $\begin{array}{l}\text { RHYNCHippus } \\
\text { cingulum on the inner } \\
\text { face }\end{array}$ & $\begin{array}{l}\text { MORPHIPPUS } \\
\text { no cingulum }\end{array}$ & $\begin{array}{l}\text { EURYGENIOPS } \\
\text { no cingulum }\end{array}$ \\
\hline Upper premolars & $\begin{array}{l}\text { cingulum on ant. int. } \\
\text { corner }\end{array}$ & $\begin{array}{l}\text { cingulum on ant. int. } \\
\text { corner }\end{array}$ & $\begin{array}{l}\text { cingulum on ant. int. } \\
\text { corner }\end{array}$ \\
\hline Upper molars & basin deep & basin shallow & $\begin{array}{l}\text { basin deep, with incipi- } \\
\text { ent secondary bays }\end{array}$ \\
\hline S.ower molars & 4 bays & bays $I$ and 2 only & bays 3 and 2 only \\
\hline
\end{tabular}

\section{Rhynchippus Ameghino}

Rhynchippus Amegh., I897, Bol. Inst. Geog. Argen., t. 18, p. 462.

The teeth of both jaws are rooted, but tend to be hypsodont. The elongated incisors of the upper series are characterized by the presence of a longitudinal furrow in the top of each tooth, which, with wear, becomes a pit, and, as it is shallow, disappears in old individuals. This is the only suggestion of a horse character in the genus, but the pit in a horse's incisor is a late development, and here it is also probably a specialization due to eating grass. Incisor $\mathrm{I}$ is the largest and they decrease in size toward either side. The canine is small, and is also marked by having a furrow in the crown, but in this case it is transverse to the long axis of the jaw.

The premolars are peculiar in having on the anterior internal corner a highly developed cingulum, which so builds out the tooth that it is usually wide and is rectangular in outline. As this cingulum rises, it incloses a bay on the ant. int. corner of the tooth, which, with wear, becomes first a bay, then a pit, and lastly may disappear entirely in old age. On each premolar the anterior and posterior loles are developed, inclosing between them an elongated Iasin, which with wear becomes a long narrow pit. On the molars, the cingulum on the ant. int. corner is wanting 'ntirely. 'The external anterior corner of the tooth, how(ver, is prolonged, so that the crown has a rhomboidal outlinc. 'The crown is made up in the typical manner of the wall, the anterior, and the posterior lobes, which inclose 
between them an elongated basin, which, as in the premolars, becomes, on wear, a pit extending oblicuely across the tooth.

The lower incisors have no furrows in the crowns, but in this genus there is a small cingulum on the inner side just above the base of the enamel. The lower canne is incisiform, and also has the basal cingulum. Each of the premolars has, on the external side, a median vertical groove, beginning at the base of the enamel, and widening toward the top. This is progresive if less marked from pm. I to pm. 4. The premolars and molars consist essentially of two cresents, the shorter anterior. and the pesterior which is about twice as long as the anterior. The details are as described on page y6, and seen in figure 5.5 .

The skull is of moderate height, nearly Hat on top with wide zygomatic arches. The sagital crest is mulerately. high, and slightly convex in the antero-posterior direction. The occipital region is overhanging and topped hy short lambedoidal crests, which, extending to either side, unite with the zygomatic arches. The nasals are large, roughy rectangular, and slightly constricted just in front of the middle. The frontals are short, and project over the orbits in strong processe's. The maxilla is large, loumling the front of the orbit, and extending backward in a strong zygomatic process which makes nearly half of the arch. The jugal, while stout, is short, and reaches from the lons zygomatic prexess of the maxillat th the short one of the squamosum. The lachrymal bone is tiny, with a low tubercle, just below which is situated the lachrymal duct. just on the margin of the orbit. Just behind the zygomatic arch, the squamosum is inflated and contains a large hollow chamber, as is typical among texedents. The matsid bullae, while relatively small, are swollen into a shobular form, and have a large hollew chamber. The palate extends back to just behind the last molar, a feature distinguishing this genus from Morphippus. 
Of the vertebral column, twenty-six vertebra are preserved (a few being represented by neural arches only). The atlas and axis are unknown. Five cervicals are present, each with a short, slightly opisthocoelus centrum, and with low weak spines. The foramena for the vertebra artery are usually large. Cervical 3 has a rather slender transverse process, projecting down-and backward. On cervicals 4,5 and 6 , these lateral processes are enlarged into broad lamellae, which reach their maximum of size on the sixth. Cervical 7 has no lamella, simply a slender transverse process. These transverse processes are strikingly like those of Nesolon. The thoracic vertebrae (of which I have complete or in parts I 5) have moderately high spines, which resemble those of Adinotherium, not only in the general build, but also in the presence of a foramen for the exit of spinal nerves through each neural arch. These foramena can not be referred to as adaptations, but are special features indicating close relationship with the Nesodontidae. Six lumbar vertebra are present, each having broad depressed centra, and short wide spines. 'The rest of the column is unknown.

The distal portion of the humerus is preserved, showing the trochlea to be relatively narrow, with a prominent internal phlange for the ulna. The epicondyles are both small. The supratrochlear fossa is moderately deep, the anconeal fossa very deep, a large perforation connecting the two. Of the ulna, only the distal end is preserved, and it is marked by a prominent styloid process, ending in the facet for the pyramidal, this facet continuing uninterruptedly into that for the pisiform. The two ends of the radius are preserved but its length can only be conjectured. The proximal end has a large facet for the humerus; the distal end two facets, for the scaphoid and luna respectively, the two being almost continuous, except as the outline of the shallow depressions is constricted near the middle. 
The carpus is preserved in toto and is decidedly weak for an animal of this size, though no more so than is the case of Xesodon and Adinotherium, with which forms the arrangement of the lones agrees in almost every detail. The scaphoid has a broad facet on the upper side for the radius, on the ulna side a narrow band-like facet for the luna, and distally facets for the trapezoid and the magnum, none for the trapezium. The luna is a larger bone with a broad radial facet on the upper side, a narrow facet for the scaphoid on the radial side, a larger one for the pyramidal on the ulnal side, and two hroad facets for the magnum and unciform on the lower side. The pyramidal is a low, flattened bone, with a cup-like facet for the ulna on the upper surface, an elongated flat facet for the pisiform on the palmar surface. and helow a broad facet occupying the entire lower side for the unciform. The pisiform is shaped like a tiny calcaneum, and, heside the facet for the pyramidal, has a broad contact on the styliform process of the ulna. The trapezium is a flattened nodular bone, resting against the side of the upper end of MC. II, for which it has a flattenerl contact surface, but it does not properly articulate with any of the carpals. The trapezoid is a small bone, cuboidal in shape, with the proximal facet for the scaphoid rounded, and with a narrow facet for the support of Mc. II on the distal end. The magnum is a larger bone, articulating proximally with the scaphoid and luna, on the ulnal side with the unciform and distally supporting Vi. III. The unciform is the largest of the carpal bones, articulates proximally on the luna and pyramidal, on the radial side with the magnum, and distally carries MC. IV, while on the ulnal side there is a facet for the modular vestige of Mc. V.

The metacarpals are longer than those of Adinotherium, and are much more closely pressed together, making a narrower, firmer font. Three metacarpals are present (beside the modular vestige of MC V.). MC. II and Mc. IV 
are slightly shorter than Mr. III, but not materially weaker, so that all three would reach the ground when the animal was standing. Though closely packed, the metacarpals are not grown together at any point. Distally each has a narrow trochlea, which carries a median crest on the palmar side only. I Inder the distal end of each metacarpal, there is a pair of small sesamoid bones.

All the phalanges are very short and weak, with the articular surfaces cut under obliquely, suggesting that the toes are bent upward. I)istally each toe ends in a slender cleft ungual phalanx, suggesting a claw-like hoof. Rhynchippus clearly walked in a semidigitigrade manner, the weight coming principally on the metapodials, the foot as a whole resembling that of a dog.

The pelvis is unidentified. Though the bones are of about the same weight, the hind limb is longer than that of Adinotherium. The femur has a rounded head on a short but distinct neck, with the pit for the round ligament on the posterior margin of the head. The narrow digital fossa is deep. The greater trochanter is rugose and strong, but does not rise quite to the height of the head. The lesser trochanter makes a strong shelf-like process well below the head, while the third trochanter is a prominent process about the middle of the shaft, on the posterior side. The shaft is broad and flattened above, but narrows and becomes circular in section below. The condyles are relatively small, the inner being the smaller and more convex, while the outer is broader and less convex.

The tibia and fibula are a little longer than the femur, fused proximally, free distally, as in toxodonts. The proximal end of the tibia is too weathered to permit detailed description. However the upper end is wide and flattened from front to back. Distally the bone narrows until the Inwer part of the shaft is circular in section, the distal end enlarging again in the neighborhood of the articulation. The fibula has a broad facet for the inner side of the astra- 
gulus, and on the distal end a flattened slightly concave facet for the calcaneum.

The calcaneum is longer than in Nesodontidae. It is, however, heavy and stout, the tuber broadening slightly toward the free end, on the plantar side of which there is a tendinous sulcus as in Nesodon. The fibular facet is wide, rectangular, and convex. Of the astragular facets, the sustentacular extends well back onto the tuber, and the ectal is the usual ovoid surface. Distally there is a broarl slightly concave facet for the cuboid, and external to this a narrow surface for contact on the navicular. Fxcept in length, this bone is very like that of Adinotherium. The astragulus and rest of the tarsal bones are wanting. Parts of the metatarsals and a phalanx indicate that the hind foot is of the same tridactyl type as the front, differing only in that the median digit seems to be relatively a little heavier.

Ameghino described three species of Rhynchippus, $R$. equinus, $R$. pumulis, and $R$. medianus.

\section{Rhynchippus equinus Ameghino}

R. equinus Amegh., 1897, Bol. Inst. Geog. Argen., t. 18, p. 463.

This species is the dominant one in the Deseado from the Chico del Chubut, west of Puerto Pisser, no less than fourteen individuals being represented in our collection, three by skulls, and one by the major part of a skeleton which was found associated with the skull of Leontinia, but was determined as belonging to this species, by the duplication of the radius with a specimen having the radius and lower jaws associated. The description of the generic characters is largely based on this skeleton. The three species are differentiated largely by their size, $R$. cquinus being the largest, but as compared with $R$. pumulis it is not only larger but much heavier built.

The skull has been described under the generic discussion. In young individuals, the furrow in the incisors and 
canine is marked as a groove, later as a pit, and still later is lacking altogether, as is the case in the specimen figured, for all three of my more complete specimens are old individuals, as is also Ameghino's type. All the incisors show

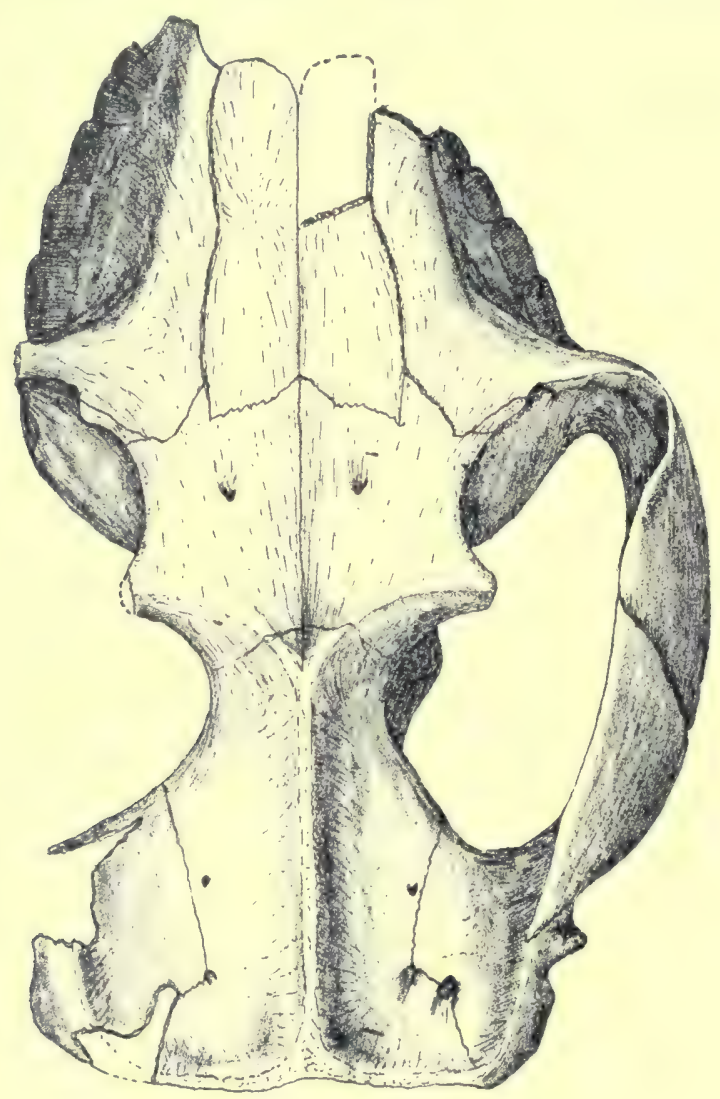

Fig. 53. Dorsal view of skull-1/2 natural size.

the cingulum near the base of the enamel. On account of the development of the cingulum on the inner anterior corner of the premolars, these teeth are broadened out and werhang the palate in a marked degree, and are also much wider than long. Nolar $\mathrm{I}$ is intermediate in character 
between the premolars and the succeeding molars, heing only slightly rhomboidal in outline, while in the last two molars the anterior external corner is markedly prolongerl.

In different individuals, the lower jaw varies greatly in height, hut this seems to me to be individual and sex variation. The three incisors and the canine are subequal in

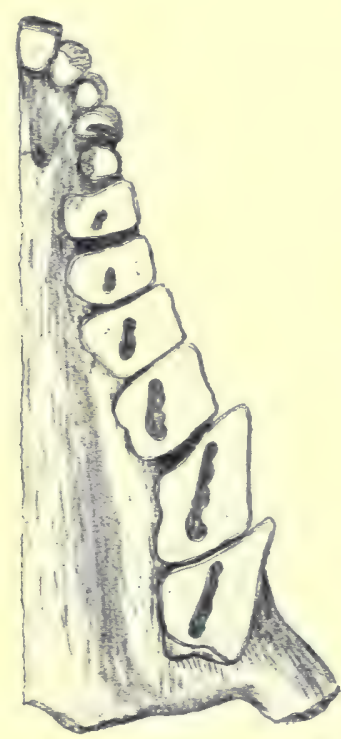

Fig. 54. Left upper dentition, old individual-1/2 natural size.

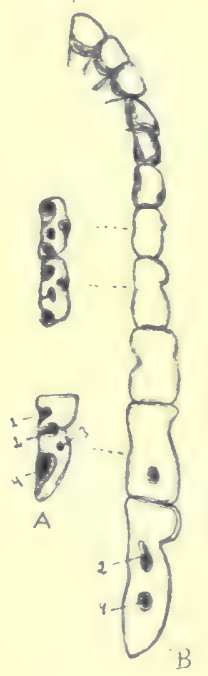

Fig, 55, Right lower dentition of $R$. equinus; $A$, of a young individual; $B$, of an old individual- $1 / 2$ natural size.

size, closely crowded, and each with a small cingulum near the base of the enamel.

\section{Measurements of Sktll, Specimen 3191}

Skull, length from front of nasal to hack of lambdoidal crest

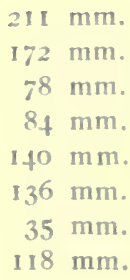

Skull, width across zygomatic arches

Skull, width across postorbital processes

Skull, height above molar 2

Dentition, from upper inc. I to molar 3

Dentition, from lower inc. I to molar 3

Mandible, height under molar 2

Mandible, height under the articulation

$118 \mathrm{~mm}$. 
The atlas and axis are wanting, and the characteristics of the other cervicals have been given under the generic description.

Measurements, Specimen No. 3291.

Cervical 3 , length of centrum.

$18 \mathrm{~mm}$.

Cervical 5 , length of centrum

$18 \mathrm{~mm}$.

Cervical 6 , length of centrum

$21 \mathrm{~mm}$.

Cervical 6, height from base of centrum to top of spine

$74 \mathrm{~mm}$.

(ervical 7 , length of centrum

2 I $\mathrm{mm}$.

Cervical 7 , height from base of centrum to top of spine

$55 \mathrm{~mm}$.

The first three or four of the thoracic vertebrae are represented only by their neural arches and spines. There

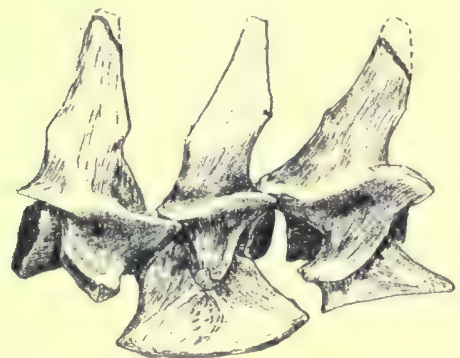

Fig. 56. Cervicals, 5,6 and $7-1 / 2$ natural size.

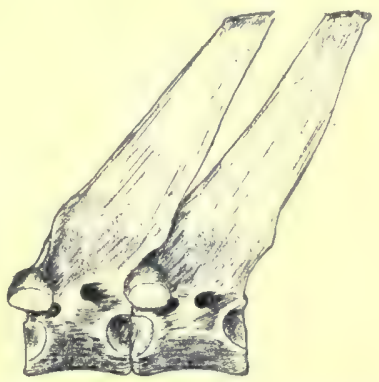

Fig. 57. Dorsal 6 and $7-1 / 2$ natural size.

were at least fifteen in the series, for I have that number represented, hut more prohably the number was sixteen as in the case in Adinotherium. Typical vertebrae measure:

\section{SPECIMEN 329I}

Thoracic 3 , langth of centrum

Thoracic 3 , height from hase of centrum to spine

2 I $\mathrm{mm}$.

Thoracic 6 , length of centrum

$56 \mathrm{~mm}$.

Thoracic 6, height from base of centrum to spine

$22 \mathrm{~mm}$

Thoracic 14, length of centrum

$79 \mathrm{~mm}$.

$26 \mathrm{~mm}$.

Thoracic I4, height from base of centrum to spine

$65 \mathrm{~mm}$.

In my series, there are six lumbars, which is one more than is credited to Adinotherium, though in that genus the 
number has not heen definitely fixed. Typical lumbars measure as follows:

Lumbar 2, length of centrum

Lumbar 2, height from base of centrum to spine

$29 \mathrm{~mm}$.

$65 \mathrm{~mm}$.

Lumbar 4 , length of centrum

$31 \mathrm{~mm}$.

Lumbar 4 , height from base of centrum to spine

$57 \mathrm{~mm}$.

There is nothing to represent the sacrum or caudals.

Only the lower half of the humerus is preserved and that with specimen 3I9I, and it measures:

Humerus, diameter of shaft

Humerus, greatest width of distal end

Humerus, width of trochlea

$22 \mathrm{~mm}$.

$46 \mathrm{~mm}$.

$36 \mathrm{~mm}$.

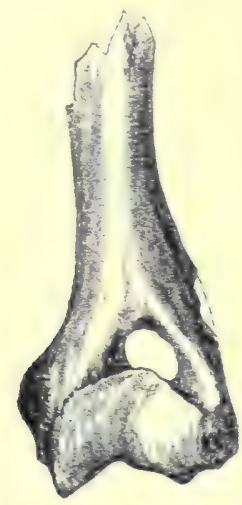

Fig. 58. Humerus-I/2 natural size.

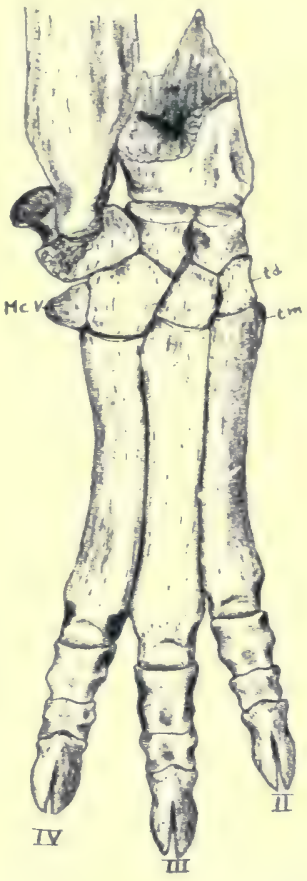

Fig. 59. Right front foot-I/2 natural size.

The distal ends of the radius and ulna are preserved in specimen 329I, as they were found in association with the carpus.

Radius, diameter of the distal end

$29 \mathrm{~mm}$.

I'na, diameter just above styloid process

$21 \mathrm{~mm}$.

Ulna, diameter of styloid process

I I $\mathrm{mm}$.

The carpus is carefully drawn, from which the various measurements may be obtained. There is a tendency for 
the two rows of carpals to alternate, but this is not advanced to any considerable degree. The trapezium is entirely isolated from the other carpals, and lies as a flattened scale, on the side of the upper end of Mc. II.

The metacarpals are closely crowded together, making a compact foot with very little freedom of motion in its upler part. The three carpals are of nearly equal length, though the third is slightly heavier and longer than the

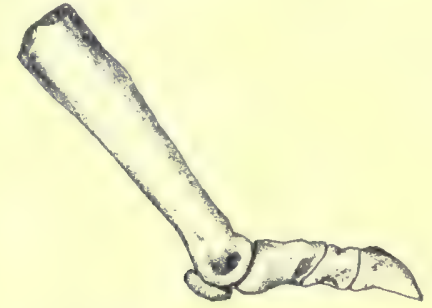

Fig. 60. Digit 4 of Rhynchippus from the side- $1 / 2$ natural size.

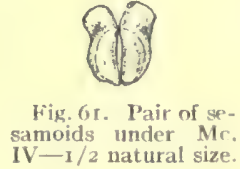

others, but there is no tendency toward a further reduction of the toes.

Metacarpus II, length $67 \mathrm{~mm}$. Metacarpus III, length $74 \mathrm{~mm}$. Metacarpus IV, length

Under each metacarpel are two small sesamoid bones which lie either side of the low crest of the metacarpus. The toes are all short, with flattened articular ends, which are cut under in a very oblique manner. The second phalanx is much shorter than the others, while the distal, or ungual phalanx, is the longest and highest of the three. Each ungual phalanx is cleft by a deep narrow notch, much more suggestive of a claw than a hoof. The phalanges of all the toes are subequal in size, so that the measurements of the middle digit are given.

First phalanx of digit III, length second phalanx of digit III, length

$12 \mathrm{~mm}$. Third phalanx of digit III, length 
As preserved, the femur is crushed, and the distal end of the rotular trochlea is weathered off, but all the other characters are well preserved. The femur is slender, with

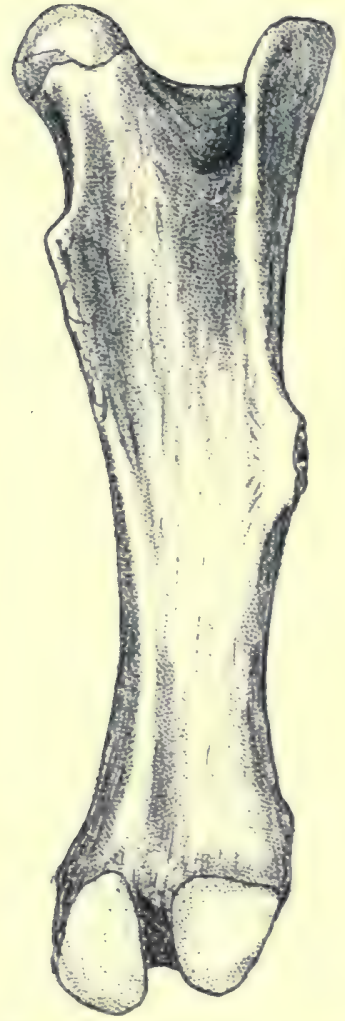

Fig. 62. Right femur posterior side-I/2 natural size.

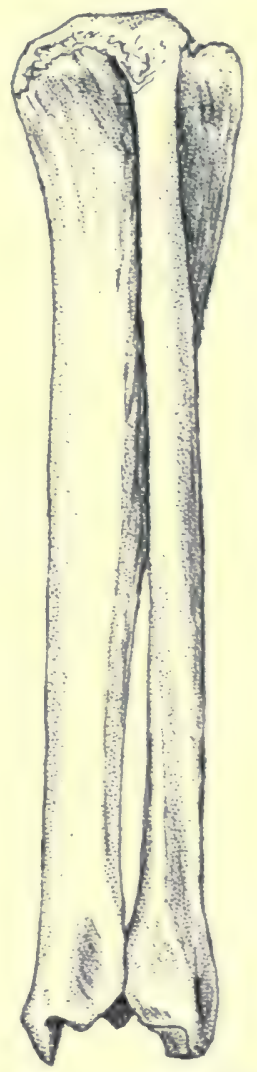

Fig. 63. Right tibia and fibula posterior side $\longrightarrow$ I $/ 2$ natural size.

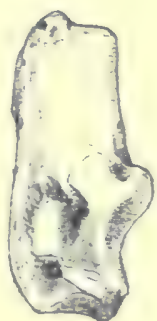

Fig. 64. CalcaneumI/2 natural size.

a small rounded head. The greater trochanter is heary but does not project above the head, the lesser is small but well marked; and the third is usually far down the shaft. Of the two condyles the inner is the smaller and more convex. 


\section{SPECIMEN 329I}

Femur, greatest length $202 \mathrm{~mm}$.

Femur, diameter of head $26 \mathrm{~mm}$.

Femur, width across head and greater trochanter

$62 \mathrm{~mm}$.

Femur, width of internal condyle

$16 \mathrm{~mm}$.

Femur, width of external condyle

$24 \mathrm{~mm}$.

The tibia is much flattened at the upper end and tapers to nearly circular in section in the distal portion of the shaft. It is fused proximally to the fibula, but free distally.

Tibia, length

Tibia, greatest width proximally

$222 \mathrm{~mm}$.

Tibia, least diameter of the shaft

5 I $\mathrm{mm}$.

Tibid, diameter of distal articular end

$24 \mathrm{~mm}$.

$23 \mathrm{~mm}$.

The fibula is a very slender bone, with the distal end swollen and heavy. As it rises from the carpus it is so twisted that it unites with the upper end of the tibia almost on the posterior surface.

Fibula, diameter of the articular end

$17 \mathrm{~mm}$.

Fibula, least diameter of the shaft

$10 \mathrm{~mm}$.

The calcaneum is of moderate length, and very stout, resembling that of Adinotherium, except that it is longer. Calcaneum, length

Calcaneum, width

$64 \mathrm{~mm}$. $28 \mathrm{~mm}$.

Of the hind foot there is preserved only the distal portions of two metatarsals, which are about the same size and character as those of the front foot, and a phalanx of the first row, also similar to the same one of the front foot.

Figure 65 gives a restoration of the animal based on the bones described in the foregoing pages. 'The animal in all features turns out a typical toxodont, adapted, by the cropping teeth, and the broad-faced premolars and molars, for a grazing animal, but its advancement in adapting itself to feeding on grass has not proceeded very far, as is indicated by the shortness of the molars. The legs are longer than in the other families of the toxodonts which would signify that it had developed some speed, but the feet have progressed toward the modification of the hoofs 


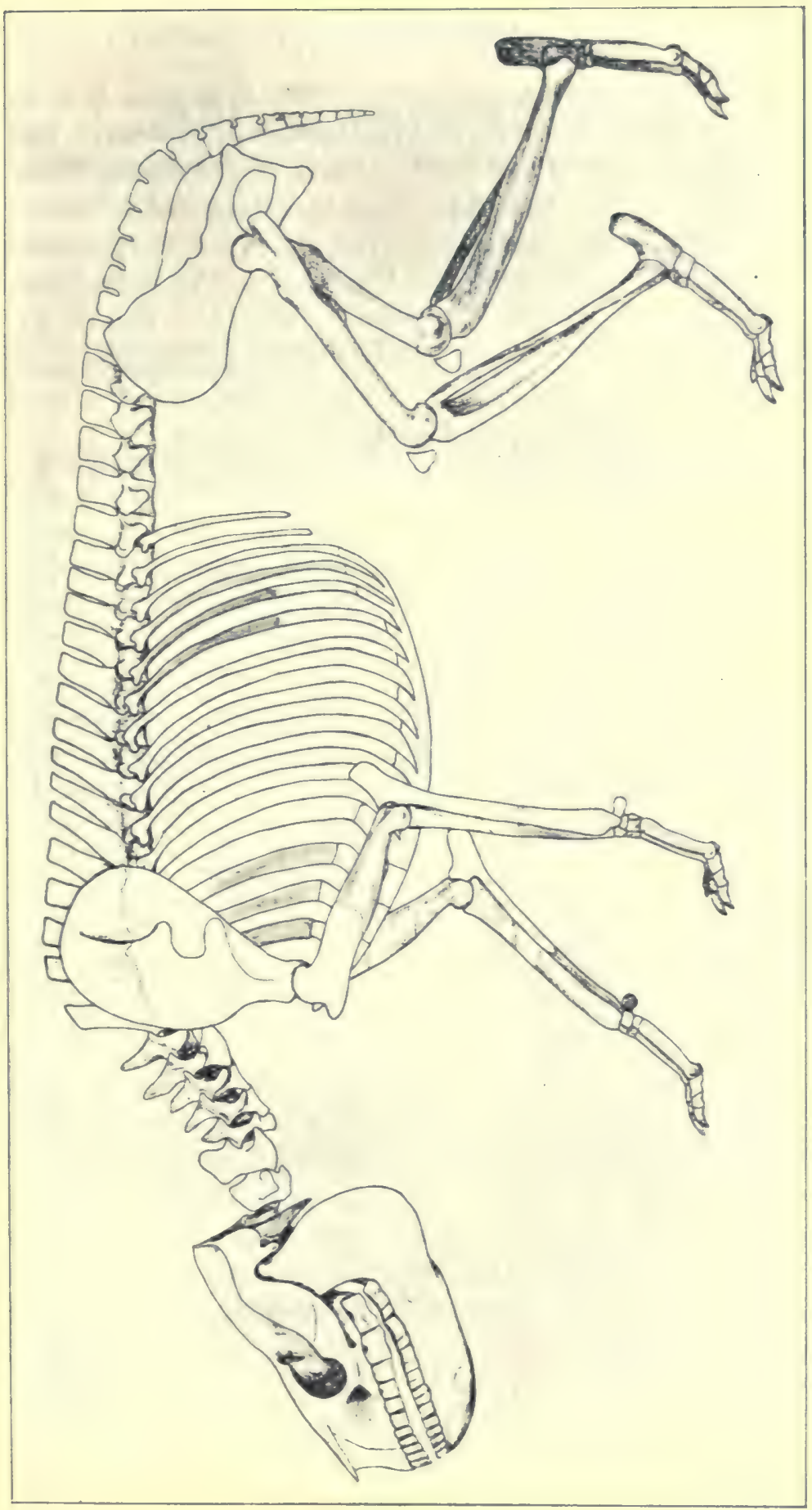


into claws, indicating a foot more like that of a dog, in which the weight is not carried on the ungual phalanges, but rather on the ball of the foot, or bases of the metapodials.

I should not feel that this group was the ancestral one to later groups of toxodonts, but it seems rather to represent a line which terminates in the Deseado or very little later, not having run up into the Santa Cruz. The line of ancestry for the toxodonts is rather through Leontinidae.

\section{Rhynchippus pumulis Ameghino}

R. pumulis Amegh., 1897, Bol. Inst. Geog. Argen., t. 18, p. 464.

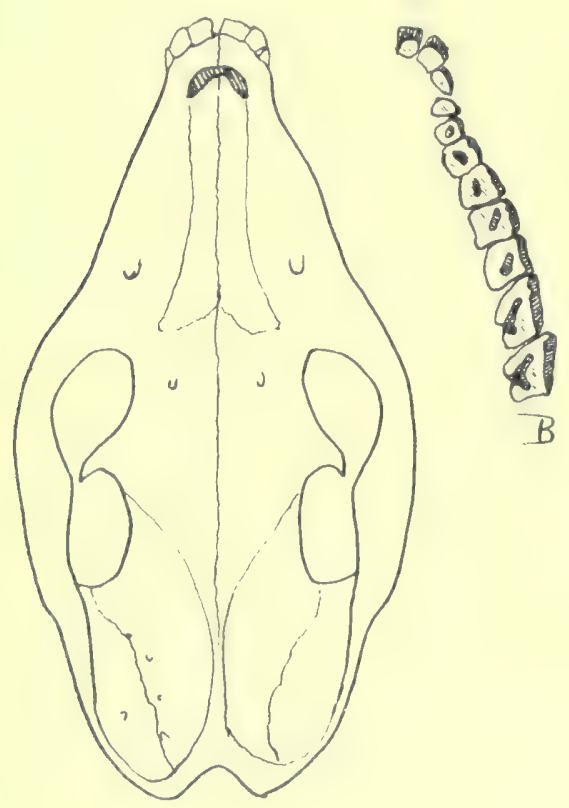

A

Fig. f,6. R. pumulis-1/2 natural size; $A$, top of skull; B. upper dentition, after Ameghino.

Skull, length over all

INuer dentition, from inc. I to $\mathrm{m} .3$

We found no specimens of this species, but Ameghino has described a complete skull, a figure of which is reproduced here. It indicates a smaller lighter built animal, differing from $R$. equinus not only in small size, but also in having a relatively longer and narrower head. The individual is a rather old one, so that the pits in inc. I and 2 have disappeared, as is also the case with the cingulum on the ant. int. corners of the premolars. Ameghino gives the following measurements in his description. 


\section{Rhynchippus medianus Ameghino}

R. medianus Amegh., I901, Bol. Acad. Nac. Cienc. Cordoba, t. 16, p. 375.

This third species is intermediate in size between the two foregoing. No figure is given, but the following measurements give the size:

Lipper molar 2, length, $17 \mathrm{~mm}$., width

II $\mathrm{mm}$.

Length of lower molars I to 3

$40 \mathrm{~mm}$.

Height of mandible under m. 2

$24 \mathrm{~mm}$.

These figures would indicate a form about I $_{5} \%$ larger than $R$. pumulis, and 35 ? i smaller than $R$. equimus.

\section{Morphippus Ameghino}

Morphippus, Amegh., 1897, Bol. Inst. Geog. Argen., t. 18, p. 459.

'This genus is very similar to Rhynchippus, with the same. dental formula, the same gresese in the upper incisors, and the same pattern of the premolars and molars. It differs, however, in the lower incisors having no cingulum at their base, in the upper molars having a shallower basin, and in bays 3 and $f$ being alsent from the lower molars. These features simply indicate a slightly less advanced specialization, less hypsodont teeth. I do not think that the bays are any of them lacking in unworn teeth, but in a less hypordont touth, with the pits extending a less distance inte the crown, all indication of the bays disappears early.

M. imbricutus is described as the type species, and four others have been described, all equal in size to .11 . imbricatus, and distinguished by the teeth being slightly more compresed, ly the external cleft of the lower molars leing deeper, or hy variations in the pits. All these features I consider to be e ither age characters or individual variations. so that all five specites of this genus are lumped unter $M$. imbricatus. 


\section{Morphippus imbricatus Ameghino}

M. imbricatus Amegh., I 897, Bol. Inst. Geog. Argen., t. I 8, p. 459.

M. hypsolodus Amegh., I897, Bol. Inst. Geog. Argen., t. 18, p. 46I.

M. complicatus Amegh., 1897, Bol. Inst. Geog. Argen., t. 18, p. 46 I.

M. fraternus Amegh., I90 I, Bol. Acad. Nac. Cienc. Cordoba, t. 16, p. 374.

M. quadrilobus Amegh., I90I, Bol. Acad. Nac. Cienc. Cordoba, t. I6, p. 374.

The general characters of this species are given under the generic description and I will here give only Ameghino's measurements which go with the figure:

Skull, length over all

2 I0 $\mathrm{mm}$.

Skull, length of the palate

$120 \mathrm{~mm}$.

Upper dentition, length the inc. I to m. 3

$120 \mathrm{~mm}$.

Diameter of the palate opposite inc. 3

Diameter of the palate opposite m. 3
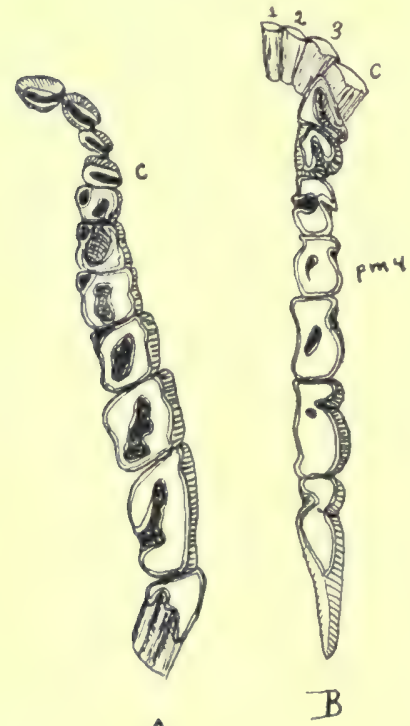

Fig. 67. M. imbricatus-I/2 natural size; $A$, upver dentition: $B$, lower denfition ifter Ameghino.

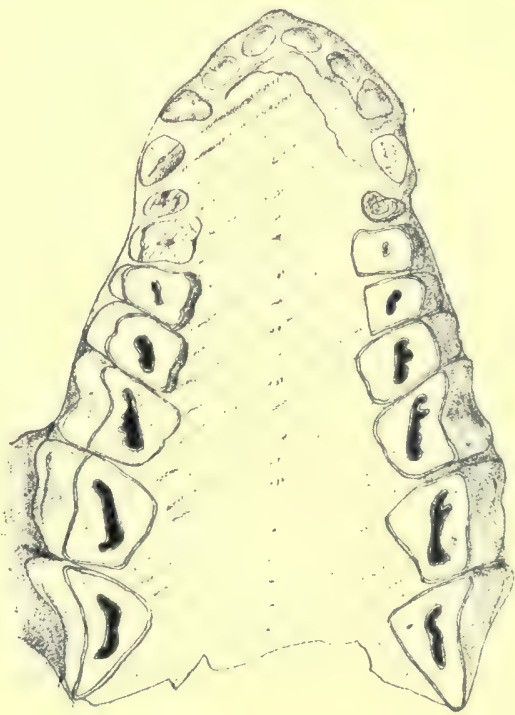

Fig, 68. E latirostris, palatal view, after a photograph of the type- $-1 / 2$ natural size; the cross hatched area represents matrix not yet removed. 


\section{Eurygeniops Ameghino}

Eurygenium Amegh., 1895, Bol. Inst. Geog. Argen., t. 15, p. 655.

Eurygeniops Amegh., 1897, Bol. Inst. Geog. Argen., t. 18, p. $4^{6} 4$.

The name first given this genus was found to be preoccupied, and therefore changed. It is a clear cut genus, differing from the others in the family in the expansion of the front of the muzzle, and hy the heary hroat character of the skull.

\section{Eurygeniops latirostris Ameghino}

E. latirostris Amegh., loc, cited above.

This is the type species and is based on a muzzle which has never been figured, but which I figure, the drawing being made from a photograph taken ly Profenor seott and kindly furnished me. The characters of the species are those of the genus, with the following measurements for specific determination, quoted from Ameghino:

Palate, length

Palate, width between incisors 3

Palate, width between premulars 2

Palate, width between molars 3

$33 \mathrm{~mm}$.

Lpper dentition, length from pm. R. to m. 3

$56 \mathrm{~mm}$.

L'pper premolar t, lenith

$82 \mathrm{~mm}$.

Cpper premolar $t$, width

I I $\mathrm{mm}$.

$19 \mathrm{~mm}$.

\section{Eurygeniops normalis Ameghino}

E. normalis. Amegh., 1897, Bol. Inst, Geog. Argen., t. 18, p. 466.

This second species is described as being much smaller than the preceding. the length from pm. + w molar 3 heing $65 \mathrm{~mm}$. 


\section{CHAPTER VII}

\section{I.FONTINIDAE}

Tins family was stablished to include a group of large, heavily built ungulates, not unlike rhinoceroses in form, which have rooted teeth, the molars being similar to those of Rhinchippidae, i. e., composed of a wall and an anterior and posterior lobes, lut with the cristae either lacking or little developed; and with the second upper, and the third lower incisors developed into tush-like caniniform teeth. Two genera are especially abundant, Leontinia of the Deseade beds, and Colpodon of the colpodon beds, the former with the formula $\frac{3 \times 43}{3 \times 43}$, the latter with $\frac{3043}{3043}$. In many Ways, the family suggests Nesodontidue, and undoubtedly belongs to that series, if not directly ancestral. The lower molars are distinctly of the same type as in all the other toxodonts, but show a tendency to become hyposodont.

The following genera have been assigned by Ameghino to the family. Some of them are based on very scant material and I have ventured to suggest in each case what disposition I have felt to be the proper one.

Leontinia, the type genus, is described in detail on pages I09-1I5.

Scaphops is based on a mandibular symphysis, which is wider than usual for Leontinia, and on a second upper incisor which is compressed. The species in the genus Leontinia show a marked degree of variability, and I can see in this only individual variability, so that I place Scaphops under Leontinia and $S$. grypus, as a synonym of $L$. gaudryi.

Steniogenium is based on a mandibular symphysis with roots only of the teeth. The incisors are proclivous and inc. 3 small. I consider this also as Leontinia, and the speries S. sclerops as a synonym of L. oxyrhynca, which I think is the female of $L$. gaudryi. 
Ancylocoelus is a valid genus, differentiated hy its dental

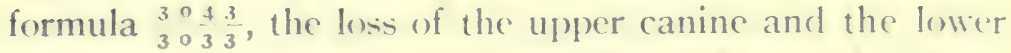
canine and first premolar distinguishing it from either Leonlinia or Colpodon.

Rodiotherium is hased on a mandibular symphysis which would indicate an animal with the same formula as the foregoing genus, differing only in that lower incisor 3 is large. This, to my mind, does not make a generic character, and at most the speries. $R$. armatum, can only be: considered an independent species belonging to the genus Ancylocoelus.

Loxocoelus is a very questionahle genus, hased simply: on an upper molar, which "is similar to that of IIomolodontotherium, hut more squared." I feel that in regard to this genus it should stand as unknown until more material is found.

In our collection, over twenty skulls and jaws helonging to this family turned up, hut all clearly belong to two types. the typical Leontinia gaudryi, and some others in which the caniniform teeth are not so well developed. which are either L. oxyrhynca or, as I believe, the female's of $L$. gaudrvi. It is this uniformity of the material which leads me to doubt the validity of the considerable number of genera which Ameghino has established, for I found on sectioning the teeth that between the little worn crown and the much worn one there was a marked difference in the appearance of the infoldings and in the development of the pits.

\section{Leontinia Ameghino}

Leontinia Amegh., 1895, Bol. Inst. Geog. Argen., t. 15, p. 647.

Leontinia Amegh., 1897, Bol. Inst. Geog. Argen., t. 18, p. 469.

Scaphops Amegh., 1897, Bol. Inst. Geog. Argen., t. I 8, p. 475.

Steniogenium Amegh., I 895, Inst. Geog. Argen., t. 15, p. 654.

Steniogenium Amegh., I 897, Inst. Geog. Argen., t. 18, p. 475.

Colpodon Gaudry, in part, Igo6, Anal. Palaeontologie, t. I, p. 30.

The formula is $\frac{3 \mathrm{I}+3}{3 \mathrm{I}}$; type species $L$. gaudryi. Of all the animals in the Deseado, this is the most abundant. 
Using this species as a basis, the following are the characteristic features. The first upper incisor is a small cropping tooth, with a well-developed cingulum high up on the inner face, which, when the tooth is worn down to the proper level, unites with the main part of the crown and incloses for a short time a small pit. On the external face there is also a feeble cingulum near the base of the enamel. The second incisor is greatly enlarged into a caniniform tush. In the species L. oxyrhynca, this tooth is much smaller but as this reduction of the tushes is the only difference, I consider these forms as the female. The third incisor is again small, and has a well-developed cingulum on both the front and inner faces. The canine is similar to inc. 3 .

The first premolar is much reduced in size, with a weak cingulum on the outer face, and probably another on the inner side (the tooth is too much worn in my specimen to be sure). Beginning with premolar 2, the upper teeth are molariform. The premolars are rectangular in outline, each being much wider than long, and each having a cingulum on the outer side. On the inner side, along the anterior half of each premolar, there is a high cingulum, which, though interrupted at the anterior corner, continues around on to the anterior face of the tooth. On a worn tooth this anterior cingulum unites with the grinding surface, and leaves a small pit in the anterior internal corner, which is very suggestive of Rhynchippidae. In the middle of the grinding surface, there is an oblique pit, the remains of the basin in young teeth. The molars continue to increase in size toward the rear. They have a vestige of a cingulum on the external side, no cingulum on the inner side, but on the anterior side for about one third the distance there is a cingulum similar to that on the premolars. In the middle of the grinding surface is an elongated oblique pit, similar to that in the premolars, but a little more advanced, there being a trace of the development of cristae. 
In the lower dentition, the first two incisors are small cropping teeth, with the anterior face flattened and having a trace of a cingulum; while on the inner face the cingulum is well developed. Incisor 3 is developed into a tush corresponding to inc. 2 in the upper dentition. Is in the upper teeth, there are two types, that of L. oxyrhynea with the tush only about wice the size of an incisor, and that of $L$. gaudryi with it much larger.

All the premolars are molariform and of the typical toxodont character, consisting of two crescents with a pillar and septum in the posterior crescent. The septum, however, does not appear until on pm. 3 and on all succeeding teeth, and is usually indicated by a tiny pit. From the front to the hack, the premolars are progressively larger, each having a cingulum on both the internal and external faces. The molars continue to increase in size progressively, and have the same characters as the premolars, except that the crescents are more elongated, and the cingula are gradually becoming smaller toward the rear.

The skull is low and heary, with a low sagital crest, and with the lambdoidal crests continuous with the upper margin of the zygomatic arches. The nasal bones are short and wide, and are markedly raised above the nasal chamber. On the outer margin of each is a low boss, somewhat as on the nasals of the rhinoceros, Diceratherium, which would indicate that this form had a small pair of nasal horns.*

The frontal bones are broad, projecting laterally in strong postorbital processes, which, with those from the jugals, almost close the orbit behind. The premaxillae are peculiar in having a median crest on the upper surface, the top of the crest being rugose, as though in life it had continued upward as a cartilage septum. The maxillae rise well up

* Scott has restored the head of Leontinia gaudryi with a single median horn, but no specimen in my collection would indicate anything but a pair of nasal horns. See Scott, Mammals of the IVestern Hemisphere, fig. I38, I9I 2. 
on the sides of the skull, bounding the lower part of the orbit, and having a short zygomatic process. The small lachrymal is but little exposed on the exterior surface of the skull, the lachrymal pit being well inside the orbit. The zygomatic arches are broad and heavy, and composed mostly of the wide jugal bones. The palate is highly arched and relatively narrow, the crowns of the premolars and molars projecting inward over it, thus narrowing it still more. It extends back well beyond the last molar. The large tympanic hullae are hollow, and the cavity in the scfuamosum seems to be reduced in size, as compared with Rhynchippidae or Nesodontidae. The occipital condyles are set well apart and are sessile; and the paroccipital processes are long and slender.

The atlas, axis and cervical 3 are associated with the skulls. The atlas is short, heavy, and has the anterior cotyles hroad, deeply excavated and wide apart; while the posterior cotyles are nearly flat, and high as well as wide. The transverse processes are only moderately wide, but are very heavy, especially along the posterior margin. The contrum of the axis is flattened, the neural canal, wider than high, and the neural spine of moderate height. The anterior cotyles are broad and moderately convex, and the odontoid process is a stout peg-like process, somewhat higher than wide. Slender transverse processes project sharply from the centrum, and have at their bases a large canal for the vertebral artery. Cervical 3 is shorter than the axis, has a less depressed centrum, a small neural spine, and short wide transverse processes.

Though I have skulls and jaws to represent some twentyfive individuals, no limb material was found in direct association with any of them. However we did find a humerus, radius and ulna on the same level and about fifteen feet from one of the skulls, and as it corresponds in size, and as humeri of this type are the most abundant skeletal bones found (as is also the case with the skulls), I have considered 
it proper to associate these fore limb bones with these skulls. The humerus is a stout bone, of medium length, with a large sessile, and but little rounded head. The external tuberosity is wide, thick and projects a little abore the head, while the internal tuherosity is so small as to be almost negligible. The shaft is flattened laterally at the upper end, but distally is compressed in the antero-posterior direction. The supratrochlear fossa is shallow, the anconeal deep, hut there is no foramen connecting them. The external condyle is small, the internal much larger. The trochlea is narrow, with a swollen articular area for the radius, and a wider saddle-like one for the ulna. The ulna is a stout, nearly straight bone, slightly longer than the humerus. The olecranon process, though large, is not excessive. The sigmoid notch makes a deep semicircular cavity, with the articular facets expanding on either side. It was closely fitted to the radius so as to allow little or no rotary motion of the forearm. The facet for the radius is a narrow band-like area just below the sigmoid notch. The shaft is almost rectangular in section. Distally the ulna contracts sharply into a heary styloid process, on the end of which is a large convex facet for the pyramidal. which merges without interruption into the facet for the pisiform. The radius is a slenderer bone, with a relatively small proximal head, but distally expanded in to a much larger articular end. My specimen is considerably weathered, but shows a wide shallow articular facet for the humerus, and a band-like facet for the ulna, but otherwise it gives little more than the length.

Of the hind limb, (iaudry* figures the astragulus and the calcaneum, the former short and with a low trochlea, the latter also short and with a broad facet for the fibula. Gaudry also states that the foot was tridactyle and plantigrade, but I am doubtful of the plantigrade feature.

- Anales Palaeontologie, 1906, t. 1, p. 28. 
Ameghino has made six species of this genus, L. gaudryi, L. fissicola, L. lapidosa, L. oxyrhynca, L. stenognatha, and L. garzoni. All of the first five are described as of the same size as L. gaudryi. L. garzoni is a smaller, about 60 per cent. of the size of the others. Of the first five listed, the first three have the large incisor and I consider them all L. guludryi. L. oxyrhynca and L. stenognatha are described as having small canines and I believe that this is a sexual difference only, so have considered these two species as also belonging to L. gaudryi, but females. I have made a careful comparison of L. gaudryi and L. oxyrhynca and find them identical in all the features except in the region of the canines where the latter is weaker, and can see no more than sexual differences. Usually with this weakness of the canine goes a smaller or lighter build of the lower jaw which is what would be expected. The points by which the various species were differentiated were, beside the size of the canine, the presence or absence of pit 3 , and the variation in the foldings on the outer sides of the lower molars, which I find on sectioning a tooth appear deeper or shallower according to whether the tooth was more or less worn.

\section{Leontinia gaudryi Ameghino}

L. gaudryi Amegh., 1895, Bol. Inst. Geog. Argen., t. I5, p. 648.

L. gaudryi Amegh., 1897, Bol. Geog. Argen., t. I 8, p. 472.

Scaphops grypus Amegh., I895, Bol. Inst. Geog. Argen., t. 15, p. 629.

Scaphops grypus Amegh., I897, Bol. Inst. Geog. Argen., t. 18, p. 475.

Steniogenium sclerops Amegh., I 895, Bol. Inst. Geog. Argen., t. I 5, p. 654.

Siteniogenium sclerops Amegh., 1897, Bol. Inst. Geog. Argen., t. I 8, p. 475.

I.eontinia fissicola Amegh., I 897, Bol. Inst. Geog. Argen., t. 18, p. 474.

L. (Senodon) lapidosa Amegh., 1895, Bol. Inst. Geog. Argen., t. 15, p. 649.

Females

I. oxyrhynca Amegh., 1897, Bol. Inst. Geog. Argen., t. 18, p. 472.

L. stenognatha Amegh., I 897, Bol. Inst. Geog. Argen., t. 15, p. 474.

Colpodon gaudryi Gaudry, 1906, Anal. Palaeontologie, t. r, p. 30.

This species is represented in the Amherst Collection by five more or less complete skulls, and over twenty jaws, 
being by far the commonest fossil of the I)esearto beds on the (hico del Chubut River, west of Puerto Visser. Is mentioned above, there are two types, the first, with larger

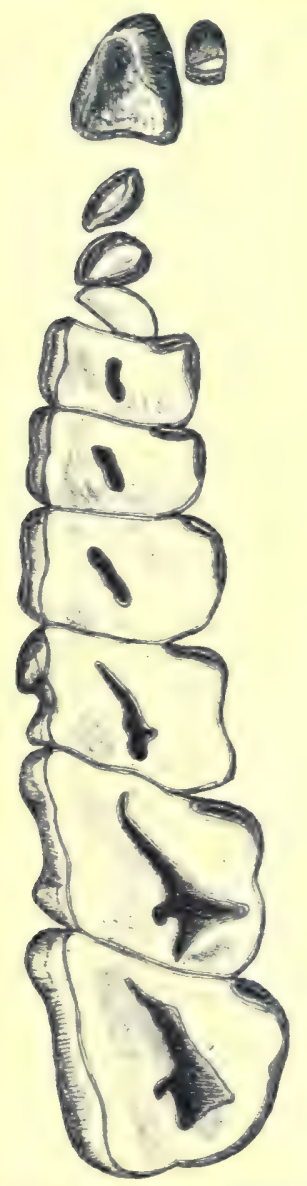

Fig. 69. Right upper dentition - I/2 natural size.

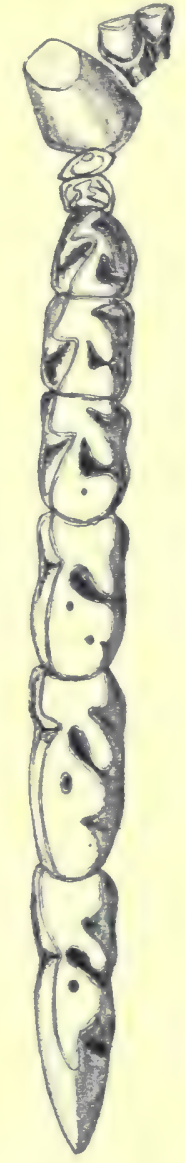

Fig. 70. Lower dentition of male

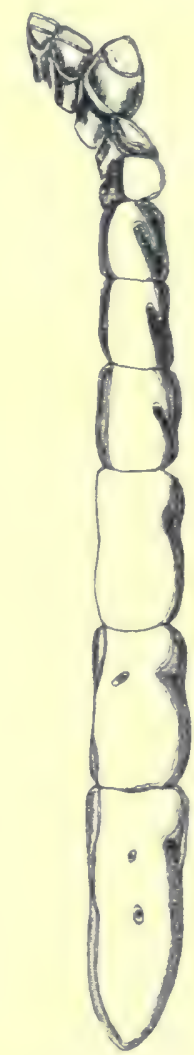

Fig. 71, Lowerdentition of female - I $/ 2$ natural size.

canines and heavier mandihles, designated by Ameghino as L. gaudryi, which I consider males; second, those with smaller canines, and lighter mandibles, slightly smaller in size, which Ameghino designated L. oxyrhynca and I con- 
sider females. Practically all of the other species are based on mandibular symphyses varying in details from the ahove, but in no case sufficiently for me to see a specific variation.

The general features have been discussed under the generic description. Incisor I has a long crown and a long root, and is greatly crowded by the tushes. Incisor 3 and pm. I have the same crowded appearance. In giving the measurements I have used a skull which is typically L. ouldryi, a male, and parallel to it have put another skull, which is typically L. oxyrhynca, the female. By comparing the two sets of figures, the shortening, of which Ameghino speaks, will be seen to be all in the region of the tushes.

Specimen 3290 Specimen $3291 \mathrm{x}$

MALE

FEMALE

Upper dentition, length from inc. I to $\mathrm{m} .3$

$227 \mathrm{~mm}$.

Upper dentition, length from pm. I to m. 3

$180 \mathrm{~mm}$.

Incisor I, length

Incisor 2 , length

$12 \mathrm{~mm}$.

Incisor 3 , length

$25 \mathrm{~mm}$.

Canine, length

II $\mathrm{mm}$.

Premolar I, length

$12 \mathrm{~mm}$.

$12 \mathrm{~mm}$.

Premolar, I width

$18 \mathrm{~mm}$.

Premolar 2, length

$18 \mathrm{~mm}$.

Premolar 2, width

$28 \mathrm{~mm}$.

Premolar 3 , length

$20 \mathrm{~mm}$.

Premolar 3, width

Premolar, 4, length

$34 \mathrm{~mm}$.

$22 \mathrm{~mm}$.

$20 \mathrm{~mm}$.

Premolar 4, width

$38 \mathrm{~mm}$.

$34 \mathrm{~mm}$.

Molar I, length

$28 \mathrm{~mm}$.

Molar I, width

40 $\mathrm{mm}$.

$24 \mathrm{~mm}$.

Molar 2, length

Molar 2, width

$36 \mathrm{~mm}$.

$38 \mathrm{~mm}$.

Molar 3, length

$48 \mathrm{~mm}$.

$33 \mathrm{~mm}$.

Molar 3 , width

$46 \mathrm{~mm}$.

$45 \mathrm{~mm}$.

$48 \mathrm{~mm}$.

$46 \mathrm{~mm}$.

Lower dentition, height of mandible under m. I

$66 \mathrm{~mm}$.

$47 \mathrm{~mm}$.

Incisor I, length

$8 \mathrm{~mm}$.

Incisor 2, length

I0 $\mathrm{mm}$.

$56 \mathrm{~mm}$.

Incisor 3 , length

$23 \mathrm{~mm}$.

$8 \mathrm{~mm}$.

Canine, length

$8 \mathrm{~mm}$.

Premolar 1, length

$13 \mathrm{~mm}$.

Io $\mathrm{mm}$.

$13 \mathrm{~mm}$.

$9 \mathrm{~mm}$.

$8 \mathrm{~mm}$. 


\begin{tabular}{|c|c|c|}
\hline & $\begin{array}{c}\text { SPECIMEN } 3290 \\
\text { MALE }\end{array}$ & $\begin{array}{c}\text { SPBCIMEN } 3291 \times \\
\text { FEMALE }\end{array}$ \\
\hline Premolar I, width & $12 \mathrm{~mm}$ & $12 \mathrm{~mm}$. \\
\hline Premolar 2, length & $18 \mathrm{~mm}$. & $16 \mathrm{~mm}$. \\
\hline Premolar 2, width & $17 \mathrm{~mm}$. & I $5 \mathrm{~mm}$. \\
\hline Premolar 3 , length & $21 \mathrm{~mm}$. & $18 \mathrm{~mm}$. \\
\hline Premolar 3, width & $19 \mathrm{~mm}$. & $16 \mathrm{~mm}$. \\
\hline Premolar 4 , length & $24 \mathrm{~mm}$. & $2 \mathrm{r} \mathrm{mm}$. \\
\hline Premolar 4 , width & $19 \mathrm{~mm}$. & $18 \mathrm{~mm}$. \\
\hline Molar, I, length & $33 \mathrm{~mm}$. & $27 \mathrm{~mm}$. \\
\hline Molar 1, width & $20 \mathrm{~mm}$. & $20 \mathrm{~mm}$. \\
\hline Molar 2, length & $40 \mathrm{~mm}$. & $37 \mathrm{~mm}$. \\
\hline Molar 2, width & $20 \mathrm{~mm}$. & $20 \mathrm{~mm}$. \\
\hline Molar 3, length & $57 \mathrm{~mm}$. & $57 \mathrm{~mm}$. \\
\hline Molar 3 width & $20 \mathrm{~mm}$. & $20 \mathrm{~mm}$. \\
\hline
\end{tabular}

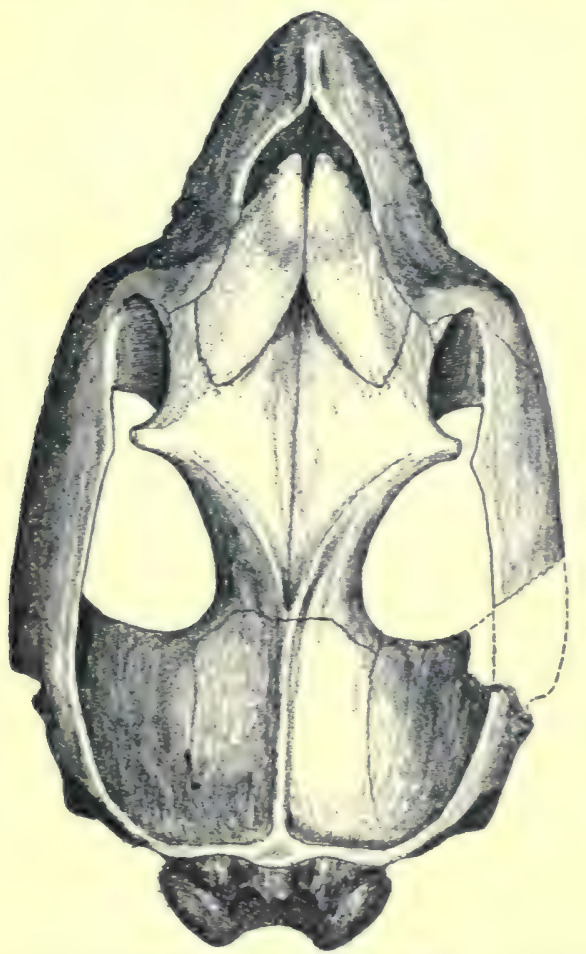

Fig. 72. Top view of skull of L. gandrsi (female)-I/4 natural size.

In the skulls there is considerable variation in size in the different individuals, but the proportions remain very 
much the same throughout. In the female the snout is relatively a little shorter, and in general the female skulls are from 5 to $\mathrm{Io}$ per cent. smaller throughout. The fol-

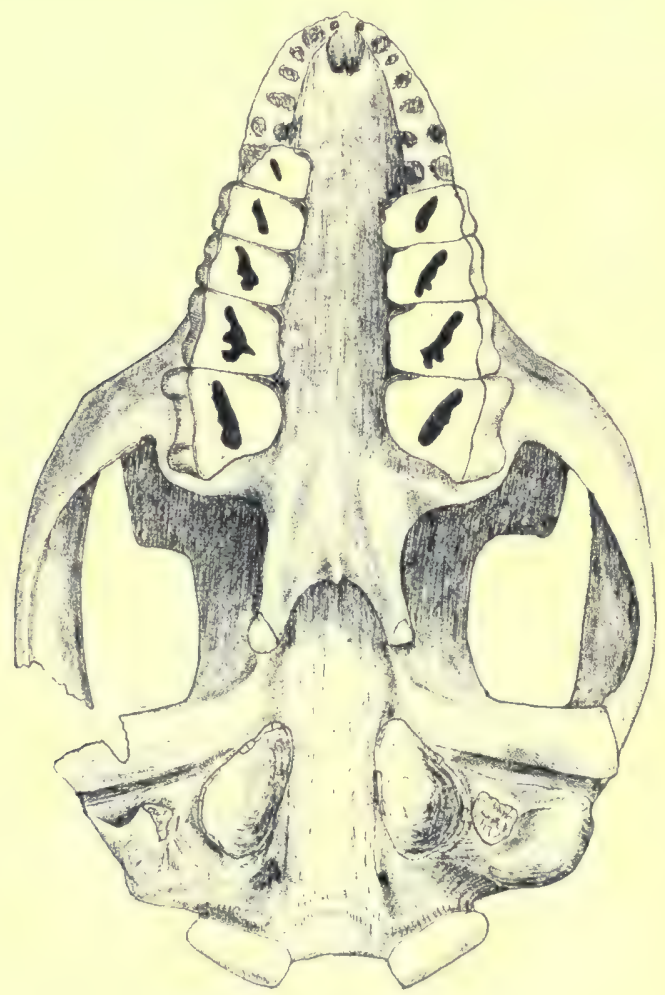

Fig. 73. L. gandryi, view of case of the skull, female (L. oxyhynea)-I/4 natural size; Tympamic bulłae broken open.

lowing two sets of figures illustrate the comparative sizes of the two sexes.

Specimen 3335 SPEcimen 329 Ix

MALE FEMALE

Skull, greatest length front to back $420 \mathrm{~mm}$. $392 \mathrm{~mm}$. Skull, greatest width Skull, length of nasal bone $252 \mathrm{~mm}$. $236 \mathrm{~mm}$. skull, length of palate

$115 \mathrm{~mm}$. $102 \mathrm{~mm}$.

$235 \mathrm{~mm}$. $230 \mathrm{~mm}$. 
The atlas associated with skull No. 3335 is a deciderlly heavy bone in all its proportions. The axis and the third cervical were associated with skull No. 329Ix, and are likewise heary bones. The following are typical measurements:

Atlas, greatest length

$86 \mathrm{~mm}$.

Atlas, greatest width

$170 \mathrm{~mm}$.

Axis, length of centrum and odontoid process

$132 \mathrm{~mm}$.

Axis, length of odontoid process

$3+\mathrm{mim}$.

Axis, width across anterior cotyles

$98 \mathrm{~mm}$.

Cervical 3 , length of centrum

$66 \mathrm{~mm}$.

Cervical 3, width of posterior end of centrum

$55 \mathrm{~mm}$.

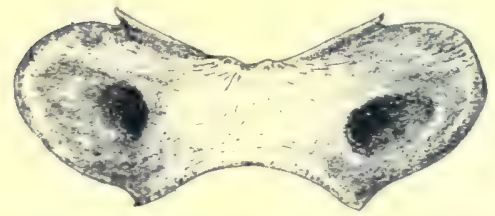

Fig. 74. Atlas seen from below-I/4 natural size.

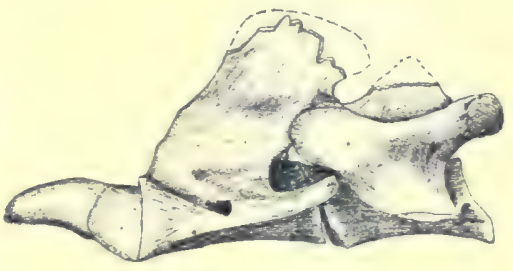
Fig. 75. Axis and cervical vertebra, No.3-I/4
natural size.

While there are other vertebrae in the collection, which probably belong to this species, I have not cared to make the association without some evidence of a definite character. However, in the case of a fore limb, which was found fairly near one of the skulls, is of proper size, and because this humerus occurs with something like the frequency of the skulls, I have been convinced that it belongeel to this species, and so described it under the genus. 'This specimen consists of the two humeri, the radius and the ulna, No. 3328 .

Humerus, greatest length

Humerus, diameter of head

$314 \mathrm{~mm}$.

Humerus, transverse diameter of the shaft

$77 \mathrm{~mm}$.

Humerus, width of distal end

$43 \mathrm{~mm}$.

I $16 \mathrm{~mm}$.

The ulna lacks some $60 \mathrm{~mm}$. in the middle of the shaft, but when fitted to the radius its length can readily be ob- 
tained. The radius is considerably weathered so that measurements of the distal end are only approximate.

Ulna, length over all

Ulna, transverse diameter of distal end

Radius, length over all

$430 \mathrm{~mm}$.

$58 \mathrm{~mm}$.

$310 \mathrm{~mm}$.

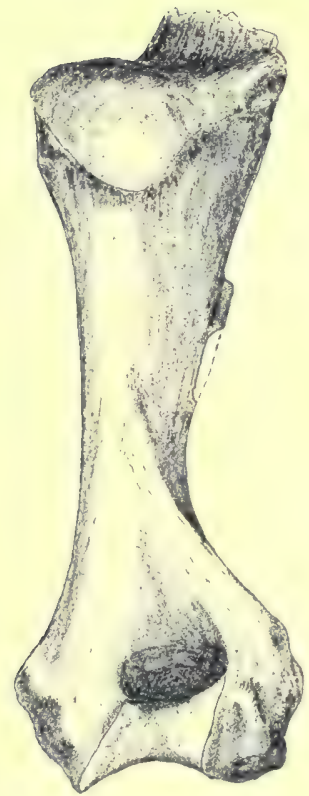

Fig 76 . Right humerus from the posterior side- $-1 / 4$ nat ural size,
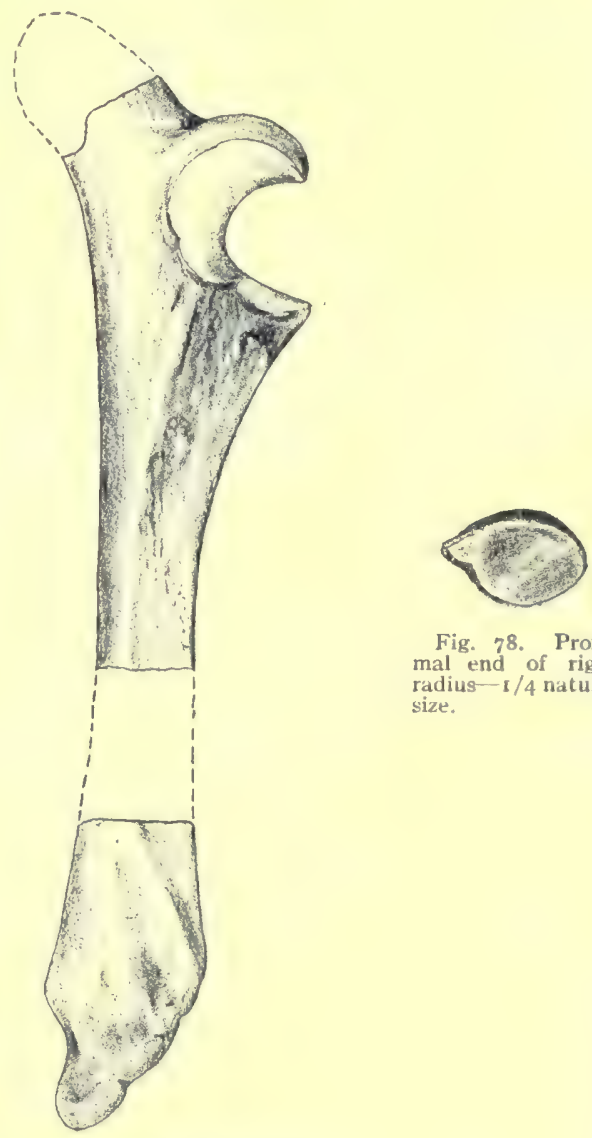

Fig. 78. Proximal end of right radius- $-1 / 4$ natural size.
Fig. 77. Right ulna from external side $-1 / 4$ natural size. 


\section{Leontinia garzoni Ameghino}

L. garzoni, Amegh., 1896, Bol. Inst. Geog. Argen., t. 15, p. 650.

L. garzoni, Amegh., 1897, Bol. Inst. Geog. Argen., t. 18, p. 47 .

We were not fortunate enough to find this species, but as described by Ameghino it is about 60 per cent. of the size of L. gaudryi. The type is a lower jaw, for which the following figures are given:

Lower dentition, length from pm. I to m. 3

$120 \mathrm{~mm}$.

Lower dentition, length from pm. I to pm. 4

$45 \mathrm{~mm}$.

Lower dentition, length of pm. 4

$15 \mathrm{~mm}$.

Lower dentition, length of $\mathrm{m} .3$

$39 \mathrm{~mm}$.

\section{Ancylocoelus Ameghino}

Ancylocoelus Amegh., I 895, Bol. Inst. Geog. Argen., t. 15, p. 652.

Ancylocoelus Amegh., 1897, Bol. Inst. Geog. Argen., t. 18, p. 475.

Rodiotherium Amegh., 1895, Bol. Inst. Geog. Argen., t. 15, p. 653.

Rodiotherium Amegh., 1897, Bol. Inst. Geog. Argen., t. 18, p. 476.

This genus differs from Leontinia in its formula, $\begin{gathered}3043 \\ 303\end{gathered}$ but, except for the loss of these canines and the lower premolars, is very similar. In this it seems to approach the line which gave rise to Colopdon. The premolars and molars are also narrower in proportion than in Leontinic. I have placed Rodiotherium also under this genus as I can not see a generic difference in the descriptions. Howerer we were not fortunate enough to find these forms. Ameghino has described four species as follows:

A. frequens, I 895, Bol. Inst. Geog. Argen., t. 15, p. 475.

Upper dentition, pm. I to m. 3

$150 \mathrm{~mm}$.

Lower dentition, pm. 2 to m. 3

$150 \mathrm{~mm}$.

Upper molar 3 , length

$39 \mathrm{~mm}$.

A. lentus, 1901, Bol. Acad. Nac. Cordoba, t. 16, p. fo7.

Upper molar 3 , length

$4^{8} \mathrm{~mm}$.

A. minor, 190r, loc. cit.

Upper molar 3

$34 \mathrm{~mm}$.

A. (Rodiotherium) armatum, see cit. above.

Based on an imperfect mandibular symphysis, in which incisor 3 is very large. 


\section{CHAPTER VIII}

\section{NesODONTIDAF}

Tins family is characterized by the teeth being hypsodont, the second upper incisor and the third lower incisor being enlarged into caniniform teeth, the upper molars complicated by the development of cristae, limbs short, feet tridactyl and semidigitigrade.

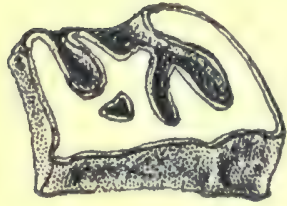

4

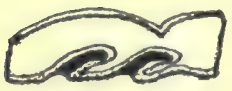

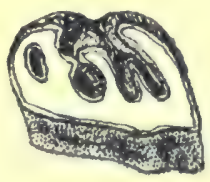

$B$

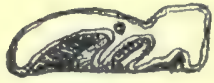

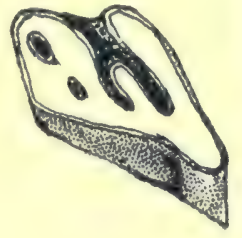

C

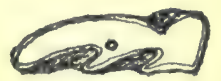

Fig. 79. A, upper and $a$ lower molars 2 of Proadinotherium; $B$, upper and $b$ lower molars 2 of Coresodon; $C$ upper and $c$ lower molars 2 of Neudon-1/2 natural size.

In the Santa Cruz, the family is represented by the two genera Nesodon and Adinotherium. In the Deseado we find Proadinotherium evidently ancestral to Adinotherium and very little differentiated from it. Ameghino has described a genus, Pronesodon, which is evidently ancestral to Nesodon. I have referred Coresodon to this family because the molars of the upper and lower jaws are very close to those of Adinotherium. Ameghino has also described two genera, Nesohippus and Interhippus, based on upper molars which are very similar in pattern to Adinotherium and which I believe belong to this family, if they prove to be valid genera, of which I have some doubt, fereling that they will prove to be the deciduous upper pre- 
molars of Proadinotherium or some similar form. The genus Senodon, which Ameghino also places in this family, I feel will prove to be worn teeth of Leontinia.

\section{Proadinotherium Ameghino}

Proadinotherium Amegh., 1895, Bol. Inst. Geog. Argen., t. 15, p. 625.

The dental formula is $\begin{aligned} & 3 \times 43 \\ & 3 \times+3\end{aligned}$, as in Adinotherium, the chief difference being that the teeth are less hypsodont

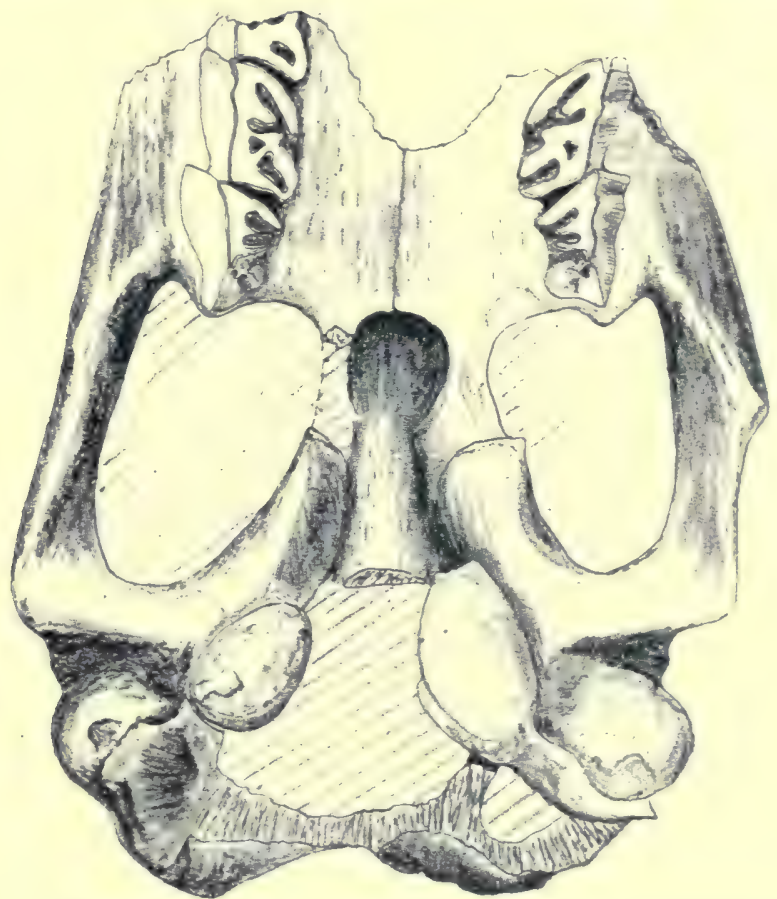

Fig. 80. P. leptognathus, rear portion of skull-I/2 natural size; shaded areas are matrix.

than in the Santa Cruz genus. Little is known as yet of the skeleton, but when more is known probably more distinctive characters will appear. Ameghino made two species, $P$. leptognathus which we also found, and P. angustidens a much smaller form. 


\section{Proadinotherium leptognathus Ameghino}

P. leptognathus Amegh., 1895, Bol. Inst. Geog. Argen., t. 15, p. 625.

P. leptognathus Amegh., 1897, Bol. Inst. Geog. Argen., t. I8, p. 467.

Of this species we found on the Chico del Chubut River, west of P'uerto Visser, three specimens; the back of a skull

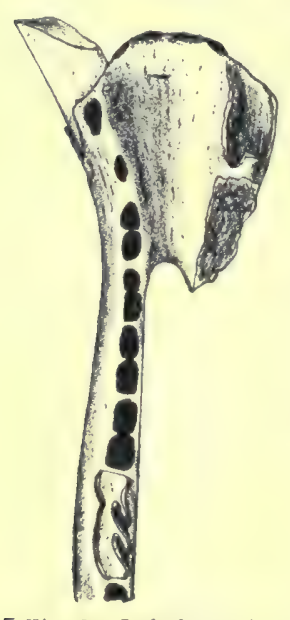

Fig. 8I. Left lower jaw with incisor 3 and molar 2

-... / 2 natural size. as far forward as molar 2, and two lower jaws. In general, the species is very similar, even to size, to Adinotherium ovinum of the Santa Cruz.

The upper molars are strongly hypsodont, curved teeth. On the upper surface, the basin is subdivided by two strong cristae into three smaller bays. In an early stage of wear, the second crista unites with the posterior lobe, converting bay 3 into a pit. On the posterior margin of the tooth, the cingulum is developed so as to appear like a third crista, which inclosed bay 4 , and when the tooth is worn, bay 4 becomes a pit also.

In my lower jaw incisor 3 is developed into a strong caniniform tush. Most of the teeth are lacking, but lower molar 2 is a strongly compressed, hypsodont tooth, surrounded by a thick layer of enamel. This tooth rises $22 \mathrm{~mm}$. above the well-developed roots, and is already considerably worn down. The pillar is prominent as a strong fold in the middle of the posterior crescent. In this specimen there is no trace of the usual pit (3) indicative of the septum, but I should expect to find it in a younger specimen. The mandible broadens in front into a scoop-like anterior end, and the alveoli of the first two incisors would indicate that they were proclivous. 'The alvecli for the other teeth are aranged as in Adinotherium. 


\section{Measirements}

Skull, width across the zygomatic arches $148 \mathrm{~mm}$.

Skull, width across opposite m. 3 (outside)

$73 \mathrm{~mm}$.

ITpper dentition, molar 2, length $25 \mathrm{~mm}$., width

$13 \mathrm{~mm}$.

Upper dentition, molar 3 , length $23 \mathrm{~mm}$., width

$12 \mathrm{~mm}$.

Lower dentition, incisor 3 , length $13 \mathrm{~mm}$., width

$7 \mathrm{~mm}$.

Lower dentition, molar 2 , length $20 \mathrm{~mm}$., width

$7 \frac{1}{2} \mathrm{~mm}$.

\section{Proadinotherium angustidens Ameghino}

P. angustidens Amegh., I 897, Bol. Inst. Geog. Argen., t. 18, p. 467.

This is based on a single lower tooth, which is considered either pm. for $\mathrm{m}$. I, and measures $13 \mathrm{~mm}$. long by $4^{\frac{1}{2}} \mathrm{~mm}$. wide.

\section{Pronesodon Ameghino}

Pronesodon Amegh., 1 895, Bol. Inst. Geog. Argen., t. 15, p. 626.

The genus is said to resemble Proadinotherium, but with the caniniform incisors proportionally much shorter. An associated calcaneum is shorter than that of Adinotherium and longer than that of Nesodon.

Two species are described.

\section{Pronesodon cristatus Ameghino}

P. cristatus Amegh., 1895, Bol. Inst. Geog. Argen., t. I5, p. 626.

P. cristatus Amegh., 1897, Bol. Inst. Geog. Argen., t. 15, p. 467.

This species is very imperfectly known, is characterized hy a large external anterior style, molars said to be $15 \mathrm{~mm}$. wide.

\section{Pronesodon robustum Ameghino}

P. robustum Amegh, loc. cit. above.

This is a larger species, of which the three lower molars are known, and which measure 16,22 , and $30 \mathrm{~mm}$. in length respectively, while they are 9-10 $\mathrm{mm}$. wide. 


\section{Coresodon Ameghino}

Coresodon Amegh., 1895, Bol. Inst. Geog. Argen., t. 15, p. 630.

Coresodon Amegh., 1897, Bol. Inst. Geog. Argen., t. 18, p. 459.

Coresodon Gaudry in part, 1908, Anal. Palaeontologie, t. 1, p. 46.

In this genus, the pattern of the upper molars is essentially the same as in Proadinotherium, and they are of the same hypsodont character, and with roots. I can now find only the fact that in Coresodon the teeth are more compressed and somewhat more hypsodont, as a feature hy which to distinguish this genus from Proadinotherium. Gaudry figures the front of a lower jaw under the name Coresodon which lacks the caniniform incisors. I have doubted the association, but should it prove correct, then this genus would be markedly different in that respect. Two species have been described, $C$. scalpridens, and $C$. cancellatus, both of which I consider the same.

\section{Coresodon scalpridens Ameghino}

C. scalpridens Amegh., 1895, Bol. Inst. Geog. Argen., t. 15, p. 630.

C. scalpridens Amegh., 1897, Bol. Inst., Geog. Argen., t. 18, p. 459.

C. cancellatus Amegh., 1901, Bol. Acad. Nac. Cienc. Cordoba, t. 16, p. 374.

Of this species we found two specimens, one containing the three lower molars, the other the second lower molar
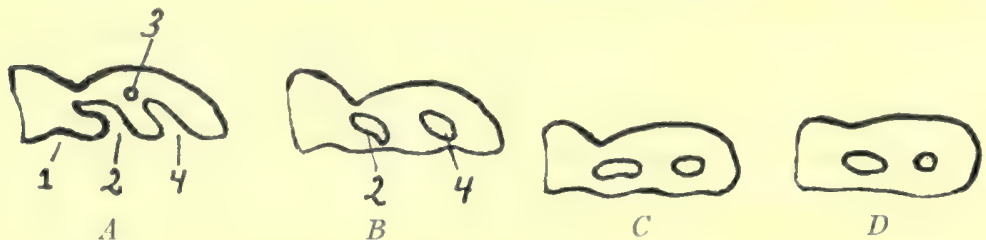

Fig. 82. Sections of second lower molar; $A$, top; $B, 4 \mathrm{~mm}$. down; $C$, $10 \mathrm{~mm}$. down; $D, 18 \mathrm{~mm}$. down-natural size.

only. In establishing $C$. cancellatus, Ameghino says it is of the same size as $C$. scalpridens, but distinguished by the basin in the upper molars being narrower, the internal fold not being bifurcated, and by the absence of islets of 
enamel. All these features seem to me to he the results of wear.

While the pattern of the upuer molars is the same as in Proadinotherium, these teeth are about as wide as they are

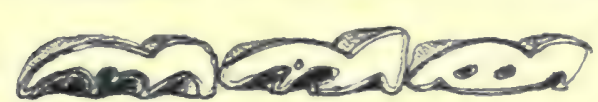

Fig. 83. Molars I to 3-natural size

long. The lower molars, however, are more compressed, with the anterior crescent occupying

about a third of the tosth. and having in the early stages a deep pit, which disappears when the tonth is worn down. In the midclle of the hasin of the posterior cresont is a large pillar, and between this and the median horn of the crescent is a tiny septum, which early unites with the pillar. leaving a tiny pit (3) which soon disappears entirely. In fact, in an old tooth, the second and fourth bays. having become pits, may even be lost also.

\section{Measurements}

Lpper dentition, molar 1 , length

Ipper dentition, molar I, width

I pper dentition, $\mathrm{m}$. I to $\mathrm{m}$. 3 , length

Lower dentition, premolar 2 , length

Lower dentition, premolar 3 , length

Lower dentition, premolar 4 , length

Lower dentition, molar $\mathrm{r}$, length $18 \mathrm{~mm}$., width

Lower dentition, molar 2, length $19 \mathrm{~mm}$., width

Lower dentition, molar 3 , length $20 \mathrm{~mm}$, width

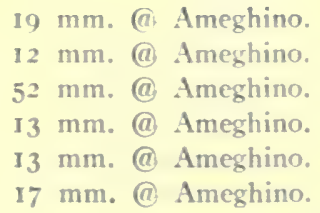

$7 \mathrm{~mm}$.

$7 \mathrm{~mm}$.

$7 \mathrm{~mm}$.

\section{Interhippus Ameghino}

Interhippus Amegh., I904, Anal. Mus. Nac. Buenos Aires, ser. 3, t. 3. P. 183. Interhippus Amegh., 1904, Anal. Soc. Cienc. Argen., t. 56, p. 34 of reprint.

This genus was estahlished on isolated teeth which chosely resemble those of this family, though the genus was placed among the Rhynchippidae hy Ameghino. The teeth described as molars are much elongated and have the cristat greatly dereloped, and in one species there is a style rising about the middle of the inner side of the molar. Another feature emphasized as characteristic of this and the next 
genus is, that the crowns are expanded much wider than the roots. While there is not yet enough direct evidence to prove it, I feel that this and the next genus will prove to be deciduous teeth, of either Proadinotherium or some related genus. Two species of this genus have been described, both from the upper Deseado.

I. phorcus Amegh., loc. cit. above.

This species is characterized by its size, the last upper molar (so called) measuring $16 \mathrm{~mm}$. long by $14 \mathrm{~mm}$. wide. I. deflexus Amegh., 1904, Anal. Mus. Nac. B. A., ser. 3, t. 3,1$) .183$.

This species is based on a worn tooth designated as molar 1 (probably d. pm. 3) $14 \mathrm{~mm}$. long by $19 \mathrm{~mm}$. wide.

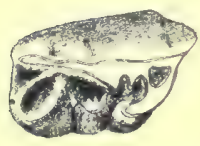

Fig. 84. I. phorcus. "Upper molar 3"-natural size, after Ameghino.

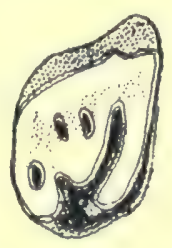

Fig. 85. I. deflexus, "Uppermolar I" - natural size, after Ameghino.

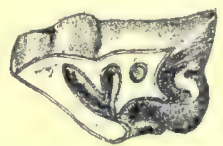

Fig. 86. N. insulatus, "Upper molar I"-natural size, after Ameghino.

\section{Nesohippus Ameghino}

Nesohippus Amegh., 1904, Anal. Soc. Cienc. Argen., t. 56, p. 34 of reprint. Nesohippus Amegh., 1904, Anal. Mus. Nac. B. A., ser. 3, t. 3, p. 218.

This genus is described as very like the foregoing, but differs in having a strong perpendicular style on the anterior external face of the upper molars. As in the preceding genus, the crown is considerably expanded above the roots. I feel that this genus will also prove to be the milk teeth of some one of the genera of this family. One species is described, based on a single tooth.

N. insulatus Amegh., I904, loc. cit. under the genus.

The species is just as described under the genus, the last upper molar measuring $24 \mathrm{~mm}$. long by $16 \mathrm{~mm}$. wide; given as from the upper Deseado. 


\section{CHAPTER IX}

\section{ISOTEMNIDAE}

This family is distinguished by the formula : it : ? hy the incisors, canine and premolar I all heing of sulerpual size, by all the teeth heing brachydent, and by the cresrents of the lower premolars and molars heing modified. On these lower premolars and molars the anterion crescent is longer than the posterior, and the short posterior crescent on the exterior of the torth; so that its anterior horn, instead of uniting with the posterior horn of the anterior crescent, comes in back to about the midclle of the anterior crescent. Then the pillar, which in the other families is situated in the posterior crescent, is opposite the prosterior horn of the pesterior crescent. The small animals which represent this family are rare in the Deseado beds. much more alundant in the ('asamayr. The family seems to have died out in the Deseado as no forms are referred to it in later epochs. We found no specimens helonging to the family; hut to make this discusion complete, I will give a digest of Ameghino sdereriptions, with repreductions of such figures as he has given. All of the genera and species are based on very fragmentary material.

The genera assigned to the family are Trimerostephunes. Pleurocoelodon, Lophocoelus and IIenricofilholia.

\section{Trimerostephanos Ameghino}

Trimerostephanos Amegh., I 895, Bol. Inst. Cieog. Argen., t. 15, p. 646. Trimerostephanos Amegh., 1897, Bol. Inst. Geog. Argen., t. 18, p. 4‘3.

This genus is hased on upper and lower teeth, and distinguished by the premolars and molars having a weak style on the anterior corner, and by the anterior lobe being considerably larger than the posterior. Four species have been described. 
T. scabrus Amegh., loc. cit for genus.

This is the type species, originally based on the third lower molar, to which was later added, upper premolar 4
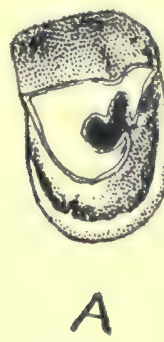
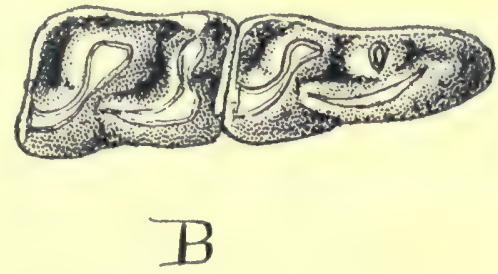

Fig. 87. T. scabrus-natural size; $A$, upper premolar $4 ; B$, lower molars 1 and 2.

and the molars, and lower molar 2. The following measurements are given:

I pper premolar 4 , length

I pper molar 2, length

I5 mm., width $21 \mathrm{~mm}$.

I'pper molar 3, length

$31 \mathrm{~mm}$.

$35 \mathrm{~mm}$.

Lower molar 2, length

$20 \mathrm{~mm}$.

Lower molar 3 , length

$29 \mathrm{~mm}$,

T. scalaris Amegh., 1897, Bol. Inst. Geog. Argen., t. 18, p. 483 , is based on lower pm. 2 to m. 2, a somewhat smaller species than the preceding, the series as given measuring $53 \mathrm{~mm}$.

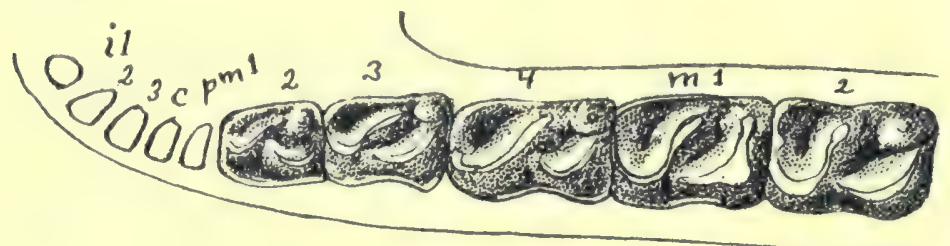

Fig. 88. T. scalaris, premolar 2 to molar 2-natural size.

T. angustus Amegh., 1897, Bol. Inst. Geog. Argen., t. 18, p. 484 .

This species is described without a figure, as smaller than T. scaluris, pm. 2 to $\mathrm{m} .2$ being $59 \mathrm{~mm}$. The mandible is also slenderer. 
T. biconus Amegh., 1897, Bol. Inst. Geog. Argen., t. I8. p. 484 .

This species is based on two lower premolars, said to be the same size as $T$. angustus, but with the pillar larger.

\section{Pleurocoelodon Ameghino}

Pleurocoelodon, Amegh., I895, Bol. Inst. Geog. Argen., t. 15, p. 645.

Pleurocoelodon, Amegh., I 897, Bol. Inst. Geog. Argen., t. 18, p. 484 .

This genus is distinguished by the absence of the style on the anterior external margin of the upper molars, in-
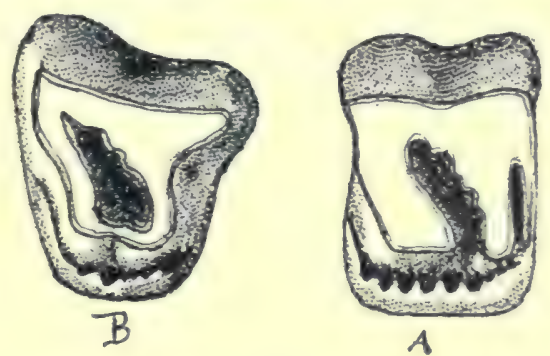

Fig. 89. P. wingei-natural size; $A$, first molar; $B$, third molar.

stead of which the external face is excavated medianly. Two species are described, based on isolated upper teeth.

\section{P. wingei Ameghino}

P. wingei Amegh., 1895, Bol. Inst. Geog. Argen., t. 15, p. 645.

P. wingei Amegh., 1897, Bol. Inst. Geog. Argen., t. I 8, p. 485.

This species is founded on a couple of isolated molars. probably belonging to the same individual. The following measurements are given:

I'pper molar I, length

Upper molar 3, length

$22 \mathrm{~mm}$., width $26 \mathrm{~mm}$.

$24 \mathrm{~mm}$, width $29 \mathrm{~mm}$.

P. cingulatus Amegh., loc, cit. above, is hased on an incomplete upper molar, probably the second, which is distinguished by having the internal cingulum excessively developed. It measures $30 \mathrm{~mm}$. in length. 


\section{Lophocoelus Ameghino}

Lophocoelus Amegh., 1904, Anal. Soc. Cient., Rep. Argen., t. 58, p. 245.

Lophocoelus Amegh., 1904, Anal. Mus. Nac., ser. 3, t. 3, p. 352.

The genus is founderl on a single upper third molar from Mazaredo, which is distinguished by a feeble style on the external face, by the anterior lobe being obliquely placed, and by the presence of a small secondary bay on the posterior side of the great internal basin.

L. macrostomus Amegh., loc. cit. above.

This species is the only one described, and has the generic features, the upper m. 3 being $2 \mathrm{I} \mathrm{mm}$. long, by 25 mm. wide.

\section{Henricofilholia Ameghino}

Henricofilholia Amegh., rgor, Bol. Acad. Nac. Cordoba, t. 16, p. 404.

The type species is $I I$. cingulata, hased on a single upper molar. In general the upper molars are similar to those of Leontinia, but more brachydont, and with the internal cingulum well developed and tending to be crenulated. Four species have been made, all based on isolated upper

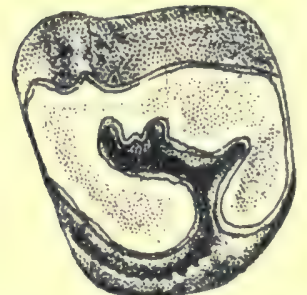

Fig. 9o. II. cingulata, upper molar I - natural size, after Ameghino. molars.

\section{Henricofilholia cingulata}

Ameghino

H. (? Parastropotherium) cingulata Amegh., Bol. Inst. Geog. Argen. t. 15, p. 640.

H. (? Parastropotherium) cingulata Amegh., 1897, Bol. Inst. Geog. Argen. t. 1 8, p. 450.

H. cingulata Amegh., 1901, Bol. Acad. Nac. Cienc. Cordoba, t. 16, p. 404.

This is based on an upper molar I of which I reproduce Ameghino's figure. It measures $28 \mathrm{~mm}$. long by $29 \mathrm{~mm}$. wide. 
H. lustrata Amegh., Igor. Bol. Acad. Cienc. Cordoba, t. I6, p. 405 .

This species is smaller than the preceding, and is based on an upper molar $\mathrm{I}$ and a last lower molar. The measurements are as follows:

Upper molar $\mathrm{I}$, length $25 \mathrm{~mm}$., width $25 \mathrm{~mm}$. Lower molar 3 , length $25 \mathrm{~mm}$, width $12 \mathrm{~mm}$.

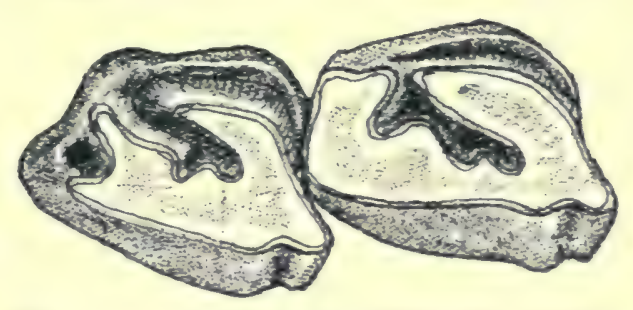

Fig. 9r. H, inaequilatera, upper molars 3 and 4 -natural size, after Ameghino.

H. inaequilatera Amegh. loc, cit. above.

This species is larger than the preceding with the internal cingulum more developed. L pper molar 2 measures $30 \mathrm{~mm}$. long by $29 \mathrm{~mm}$. wide.

H. circumdata Amegh., loc. cit, above.

This is a still larger type, with the internal cingulum enormously dereloped. L pper molar I measures $+2 \mathrm{~mm}$. long by $36 \mathrm{~mm}$. wide. 


\section{CHAPTER X}

\section{Homalodontotheria}

THE forms making up the IIomalodontotheria are characterized by a dentition which is clearly a derivative of that of Toxodontia, but is distinguished by the teeth being brachyclont, by the canines being the teeth which tend to become tush-like, though not advancing to a marked degree. But the distinctive feature of the suborder is found in the feet, which are clawed, the ungual phalanges being deeply cleft; and further, the animals seem to have walked on the sides of the foot, suggesting the Ancylopoda; but there does not seem to have been a phylogeretic relationship, rather it is a case of parallel development. Most of the forms found are of considerable size, and they are relatively scarce in all the formations.

The representatives of the group in the Deseado all belong to the genus Asmodeus, which seems to be directly ancestral to the Santa ('ruz genus IIomalodontotherium, which seems to be the last representative of the series, no specimens referable to the suborder having been found in later beds.

\section{Asmodeus Ameghino}

Asmodeus Amegh., I 895, Bol. Inst. Geog. Argen., t. 15, p. 643.

Asmodeus Amegh., 1897, Bol. Inst. Geog. Argen., t. 18, p. 476.

The formula is $3 \frac{3}{3} \frac{4}{4} \frac{3}{3}$, the upper incisors have pits in the crowns; the canines are moderately enlarged; the upper premolars and molars consist of an external wall, with an anterior and posterior lobe, the lower premolars and molars are typically like those of toxodonts. Two species have been distinguished, a larger, A. osbormi, and a smaller, A. scotti. Our collection contains seven specimens, all of which should apparently be assigned to $A$. osborni. 


\section{Asmodeus osborni Ameghino}

A. osborni Amegh., r895, Bol. Inst. Geog. Argen., t. 15, p. 644.

A. osborni Amegh., 1897, Bol. Inst. Geog. Argen., t. 18, p. 478.

Homalodontotherium osborni Gaudry, 1906, Anal. Palaeontologie, t. I, P. I1.

The type of this species is a calcaneum and astragulus, to which Ameghino later assigned the rear part of a mandible with pm.t and the three molars; also a milk dentition, this last I think wrongly, for it is too small. I should interpret this specimen as deciduous inc. 2 to deciduous pm. 4 , plus permanent molar $\mathrm{I}$, in which case the permanent molar corresponds to that of $A$. scotti and it is not necessary to discuss "the remarkable bicuspid canine," as Ameghino

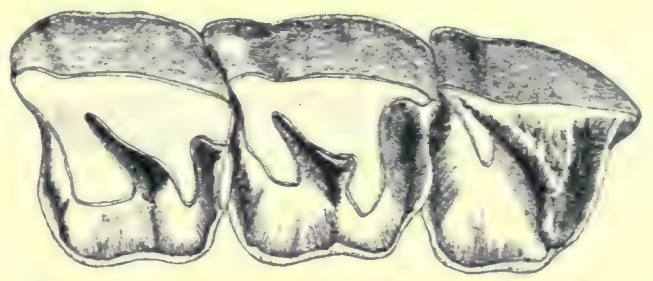

Fig. 92. Molars $I-3$ of the left side-I/2 natural size.

does. Gaudry had some of this material, upper molars, the lower end of the humerus, the ulna, calcaneum and astragulus, and he referred the genus as the same as Homoladontotherium. With this last, I can not agree. We found the three upper molars, the lower end of the humerus, part of the radius, the tibia, and two phalanges, all on the Chico del Chubut, west of Puerto Visser.

While brachydont, the external faces of the molars are high, and each has a tiny cingulum along the base of the crown. There is also a strong cingulum around the anterior, internal, and posterior faces of the crown, which on the posterior margin flares out, making a marked and characteristic ridge. The grinding surface, with its external wall and two transverse lobes, is very similar to the molar of a rhinoceros. When the tooth wears down, the 
inclosed hasin becomes a large pit. Between the posterior lobe and the flaring cingulum on the posterior margin, there is also a small posterior bay, which, in an old tooth, will also appear as a pit, lut being shallow, it does not last long.

The lower molars, as figured by Ameghino, are of the same type as those of the toxodonts, consisting of two crescents with the pillar in the middle of the posterior crescent, but the crescents and pillar are very plump; so that with wear they form broad grinding surfaces; and the bays, instead of becoming pits, first appear as notches, then disaplear entirely. Each premolar and molar has a cingulum on the internal and external sides.

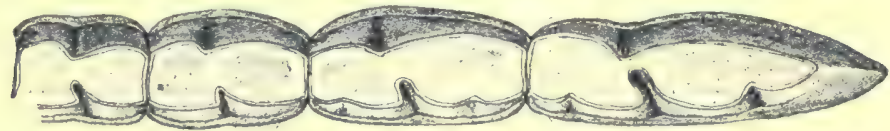

Fig. 93. Premolar + to molar $3-1 / 2$ natural size, after Ameghino.

Measurements, Specimen 3179

Upper dentition, molar $\mathbf{I}$, length

Upper dentition, molar 2, length

Upper dentition, molar 3 , length

I.ower dentition, from Ameghino's measurements

Lower dentition, premolar 4 , length

Lower dentition, molar $\mathbf{I}$, length

Lower dentition, molar 2, length

Lower dentition, molar 3 , length
$46 \mathrm{~mm}$., width $50 \mathrm{~mm}$. $5 \mathrm{I} \mathrm{mm}$., width $55 \mathrm{~mm}$. $50 \mathrm{~mm}$., width $5 \mathrm{I} \mathrm{mm}$.

$28 \mathrm{~mm}$., width $23 \mathrm{~mm}$. $34 \mathrm{~mm}$., width $24 \mathrm{~mm}$. $46 \mathrm{~mm}$., width $24 \mathrm{~mm}$. $76 \mathrm{~mm}$., width $23 \mathrm{~mm}$.

( )nly the distal end of the scapula has been found; and this shows a shallow glenoid cavity, which is much longer in the antero-posterior direction, than in the transverse. The spine rises close above the rim of the glenoid, and is unusually heavy.

The lower half of the humerus is present, and characterized by very wide epicondyles, a shallow supratrochlear fossa, a moleratcly deep anconeal fossa, no foramen, and a wicle shallow trochlea. The ulna, according to Gaudry, is a long, heary, nearly straight bone, with a shallow sig- 
moid notch, and with a large decranon process which is not bent hackward to any marked degree. The proximal

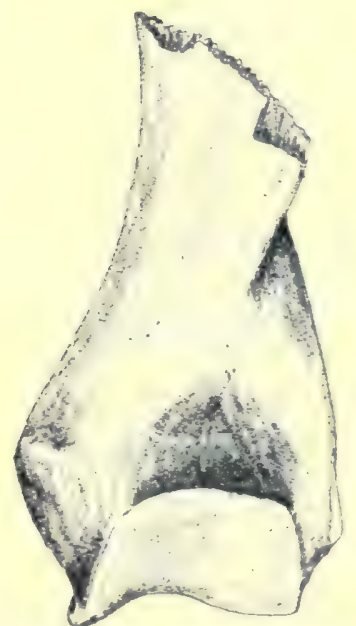

Fig. 94. Humerus, anterior sideI/5 natural size.

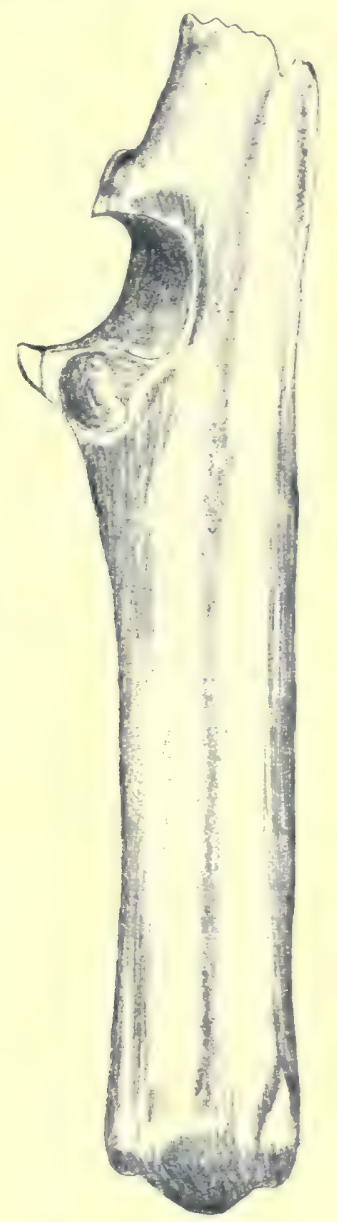

Fig. 95. Una anterior sideI/5 natural size, after Gaudry.

end of the radius has a broad doubly curved articular surface to fit the full width of the humeral trochlea. Its ulna facet is a short broad area just below the maryin of the bone, and would indicate little or no rotary motion of 
the fore arm. Most of the shaft is lacking but what is present indicates a very slender bone.

The tibia is also a rather light bone of moderate length, and is strongly curved inward, the inner margin being

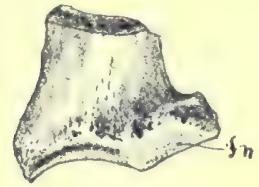

Fig. 96. Upper end of radius, ulnar side $I / S$ natural size.

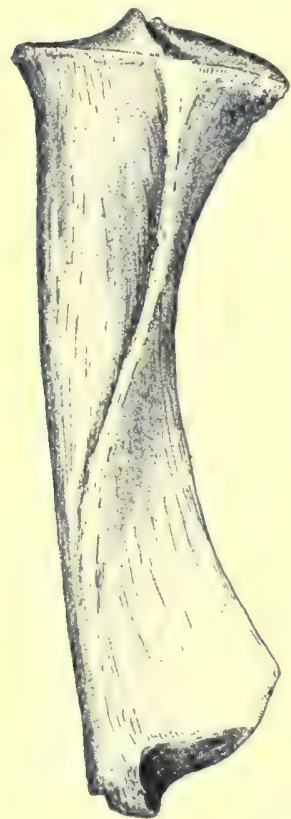

Fig. 97. Left tibia, posterior side- $1 / 5$ natural size.

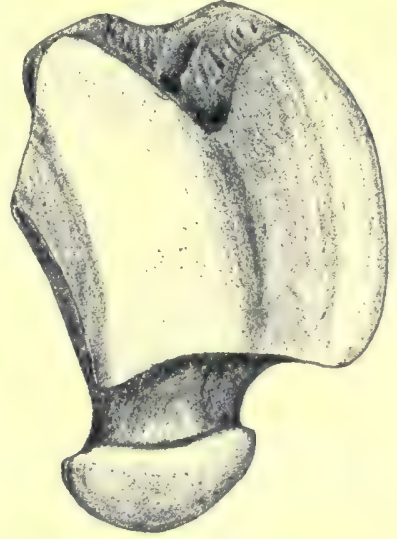

Fig. 98. Astragulus, dorsal aspect- $1 / 2$ natural size, after Ameghino.

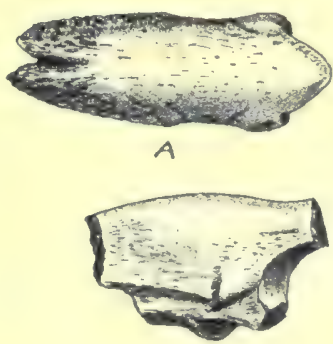

B

Fig. 99. A, Ungual phalanx, No. $3 ; B$, Ungual phalanx, No. $5-1 / 2$ natural size.

especially concave. On the wide proximal end, the inner condyle is concave, the outer convex, the two being separated by a prominent bifid spine. The shaft is slender, with a deep groove down the anterior face especially at the 
upper end, while on the posterior face, there is a large interosseus crest, which starts just below and external to the spine, and extends in a sigmoid curve three-fourths of the length of the shaft, ending on the internal border Distally the tibia is flattened antere-posteriorly. and the internal margin extends as a wiele process down to the level of the navicular face of the astragulus. The articular facet for the astragulus is a rectangular depresion, being about half as wide in the antero-posterior direction as in the transverse. This facet is only slightly concare and the inner and outer portions are not separated by an intertrochlear ridge. The filsula has not been found. but the tibia shows no indication of its having been fused to it.

Ameghino has figured the astragulus as very low, with the trochlea flattened, the internal condyle heing wider and flatter, while the external condyle is narrower and somewhat raised. The truchlea is peculiar in that its proximal margin is deeply notched ly a depresion in which there is a large perforation. The neck is prolonged and carries a large convex head articulating with the naricular only. The measurements given are, length $116 \mathrm{~mm}$., width $75 \mathrm{~mm}$.

Gaudry figures a calcaneum, showing a long narrow tuber, and the facet for the fibula as a wide shelf which projects strongly on the external side. The size as given by Ameghino is $240 \mathrm{~mm}$. long, by I $20 \mathrm{~mm}$. wide.

I have two associated ungual phalanges, one of which corresponds to that figured by Ameghino as the third. It is high, laterally compreseded, has a very rugese surface on either side, and a deep cleft in the end. This is $68 \mathrm{~mm}$. long. The second ungual is very asymetrical, also laterally compressed, and with the point curred inward. I take it to be the fifth. The tibia, the tarsus, and the phalanges strongly suggest that this animal walked on the side of its foot. 


\section{Asmodeus scotti Ameghino}

A. scotti Amegh., 1895, Bol. Inst. Geog. Argen., t. I 5, p. 643.

A. scotti Amegh., 1897, Bol. Inst. Geog. Argen., t. 18, p. 477.

This species is not represented in our collection, but I reproduce Ameghino's figure of the type, and of the milk

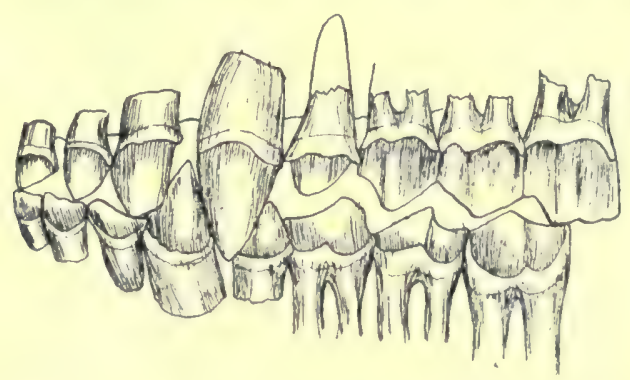

Fig. Ioo. Upper and lower incisors, canines, and premolars $-1 / 2$ natural size, after Ameghino.

dentition. Unfortunately his type figure is from the side and does not give all the desired information.

In the upper dentition, the small incisors, pitted on the crown, increase regularly in size toward the rear; and each has an external cingulum around the base. 'The canine is about twice the size of the adjacent incisor, and also has

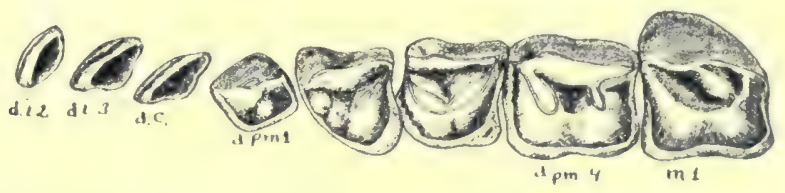

Fig. Tor, Milk incisors, canine, and premolars and permanent $\mathbf{m} . \mathbf{I}-\mathbf{I} / 2$ natural size, after Ameghino.

an external cingulum. The premolars increase regularly in size and also have at least an external cingulum. Figure IoI shows a dentition which Ameghino described as the milk set of $A$. osborni. At the same time he remarks the unusual character of the deciduous canine in being twocusped. I think this set of teeth should he interpreted as deciduous inc. 2 to deciduous pm. 4, plus the permanent 
molar I. With such an interpretation, we find the incisors normal. the canine normal though not as large as in the permanent set, and the two-cusped tonth is the first milk premolar. The last tonth in the series is considerably different from the premolars and is evidently permanent molar I, which is about the size and character of this tooth in A. scotti, much too small to belong to A. oshorni. This set of milk teeth differ from the permanent teeth in that the premolars do not have the anterior, inner and posterior cingulum, characteristic of the permanent dentition.

The following measurements are taken from Ameghino:

I pper dentition, inc. 1 to $\mathrm{pm} .4$

Upper dentition, premolar 2, length Upper dentition, premolar 3 , length Upper dentition, premolar 4 , length Upper dentition, molar $\mathrm{I}$, length Upper dentition, molar 2, length Upper dentition, molar 3 , length
$104 \mathrm{~mm}$.

$18 \mathrm{~mm}$., width $25 \mathrm{~mm}$.

$20 \mathrm{~mm}$., width $28 \mathrm{~mm}$.

$23 \mathrm{~mm}$., width $35 \mathrm{~mm}$.

$28 \mathrm{~mm}$., width $39 \mathrm{~mm}$.

$37 \mathrm{~mm}$., width $44 \mathrm{~mm}$.

$50 \mathrm{~mm}$., width $48 \mathrm{~mm}$. 


\section{CHAPTER XI}

\section{Astrapotheria}

THis group is composed of large, long limbed creatures, with a highly specialized dentition, in which the canines of the upper jaw are developed into great curved tushes, resembling those of Pyrotherium; while the canines of the lower jaw are compressed in the antero-posterior diameter and protrude laterally, like those of pigs. Upper premolars I and 2 are reduced or lacking, while pm. 3 and 4 are also reduced, but usually retained. The upper molars are brachydont, and have a crown very like that of the molars of homalodontotheres.

The lower incisors are small, proclivious, and set at intervals around the broad semicircle of the front of the fused lower jaws. The lower canines are permanently growing teeth, smaller than the upper canines, project laterally, and have the tips recurved. Premolars I and 2 are usually lacking, pm. 3 more or less reduced, and pm. 4 is a normal, short, molariform grinder. The lower molars have the same basal pattern as in Toxodonta, the crown carrying two crescents with a plump pillar in the basin of the posterior crescent, the pillar, however, being situated far forward near the anterior horn of the rear crescent.

Lydekker made an order Astrapotheria including the Astrapotheriu and Homalodontotheria, hut as the dentition of the two groups is so different, because of the enormous enlargement of the frontal region, and because of the reduction of the premolars, I am convinced that these two groups represent totally divergent lines of development; and I have therefore made each of the groups a separate suborder. 
Ameghino has described several genera, which make a progressive series and show a constantly progressive variation as far as they are known.

$\begin{array}{cl}\text { Gexes } & \text { Formation } \\ \text { Albertogaudryi } & \text { Casamayor }\end{array}$

Astraponotus

Astraponotus

\section{Formula}

\begin{tabular}{l}
$?$ I $? 3$ \\
\hline$?$ I $? 3$
\end{tabular} ted.

Parastrapotherium Deseado and Colpodon $\frac{?+23}{3 \text { I } 23}$ Post. lobe large, also a strong crista.

\begin{tabular}{|c|c|c|}
\hline Astrapothericulus & Astrapothericulus & $? 123$ \\
\hline Astrapotherium & Santa Cruz & $3 \times 23$ \\
\hline
\end{tabular}

In the [Deseado beds, beside Parastropotherium. Ameghino has described Liarthrus, based in an upper second premolar and part of another tooth. but I can see no structural variation from Parastropotherium or indeed from $P$. holmbergi; so I consider this genus as a synonym. As to the genus Traspoatherium. I can not see in it any reason for making a genus separate from Parastrapotherium.

\section{Parastrapotherium Ameghino}

Parastrapotherium Amegh., 1895, Bol. Inst. Ceog. Argen., t. 15, p. 636. Parastrapotherium Amegh., 1897, Bol. Inst. Geog. Argen., t. 18, p. 449. Liarthrus Amegh., I 895, Bol. Inst. Geog. Argen., t. 15, p. 64 I. Liarthrus Amegh., I897, Bol. Inst. Geog. Argen., t. 18, p. 451. Traspoatherium Amegh., I 895, Bol. Inst. Geog. Argen., t. 15, p. 641. Traspoatherium Amegh., 1897, Bol. Inst. Geog. Argen., t. 18, p. 450.

The genus, in general, is similar to Astrapotherium, so that Gaudry considered it the same, but Ameghino has distinguished it by the tushes being relatively of smaller size, the lower incisors larger, and by the presence of pm. 3 
in the lower series. The Deseado forms are also of considerably larger size than the Santa Cruz.

Our material includes a pair of lower jaws, two scapulae, the humerus, and the lower end of the femur.

No skull has been found in the Desearto. Those from the Santa Cruz are enormously swollen over the orbits, the massive bone making a skull wholly unique. The lower jaws are similar to those of Astrapotherium, except that the rami are deeper. The front ends are fused and expanded making the anterior much enlarged, and causing the incisors to stand at intervals as in Coryphodon. The symphysis is massive and prolonged hackward nearly to premolar 3. The rami are plump and unusually thick.

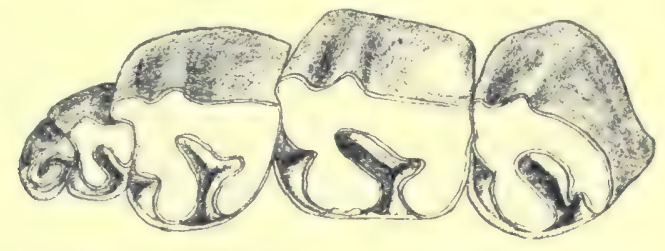

Fig. 102. Upper dentition of Astrapothericulus iheringiI/2 natural size.

()f the upper dentition, Ameghino figures only the first molar and the canine. I have given Ameghino's figure of the upper dentition of Astrapothericulus, to indicate what this would be like, for the variation is only slight. The canine is a great tush, not unlike the incisor-tush of Pyrotherium, oral in cross section with the greater diameter from front to back. The first and second premolars have disappeared. Premolars 3 and 4 are greatly reduced. The molars are very like those of $A$ smodeus, large brachydont grinclers, composed of an outer wall, and an anterior and posterior lobe. The external cingulum is a trace only, and the internal cingulum is developed in varying degrees. The basin is deep and subdivided by a crista which rises from the external wall, and as the surface is worn off unites with the anterior lobe, cutting off a small 
pit. Behind the posterior lobe is a small hasin. bounded in the rear by a second crista from the rear end of the external wall, which, as the tooth is worn down, unites with the posterior lohes, cutting off a small posterior pit, suggestive of that of homalodontotheres.

The three lower incisors are expanded at their ends into thick shorel-like crowns, each with a strong cresentic cingulum on the posterior face, and with a shallow furrow on both the front and hack faces. Relatively the incisors are much larger and longer than in 1 stropotherium.

The lower canine is flattened on the upper face, so that its cross section is close to semicircular making a typical permanently growing rooting implement. This torth is relatively shorter and smaller than in Astrupotherium.

Premolars $\mathbf{I}$ and 2 are wanting. a long diastema occupying the interval between the canine and pm. 3. Premolar 3 is greatly refluced in size, and in my specimen has fallen out, being represented by a small alveolus. I judge that in old individuals it falls out. The fourth premolar and the molars are typically those of Toxodontia. The young show two plump crescents. with a low plump pillar, situated near the anterior horn of the posterior crescent, which pillar, as the tooth wears, unites with the anterior horn.

The scapula is a remarkably heary and elongated bone, greatly arched where it lay over the ribs. The spine is high and heary, with the upper margin developed into a thick riclge like a hanister rail, which is prolonged in front to, or a little leyond, the level of the glenoid fossa. this distal portion being expanded into a broad plate more than half as wide as the widest portion of the blade of the scapula. The glenoid fossa is relatively small. oval in outline, and with the long axis parallel to the long axis of the body. The anterior margin of the articular surface is reflexed, apparently to come in contact with the base of the greater tuberosity of the humerus. This glenoid cavity 
is only large (nough to actually cover about half of the head of the humerus, and fits so that, in a position of rest, the glenoid covered the outer part of the humeral head, and only articulated on the inner part of the humerus head when the limb was bent inward. The blade of the scapula is narrow, with the proximal end prolonged and ending in a thick rugose mass. The anterior and posterior margins are rugose and thickened, the great thickness of the proximal end being due to the convergence of these thickened margins and the heavy spine. Lastly, this thick proximal end is peculiar in having on its posterior side a large rugese cavity, which was apparently to receive muscular attachments.

for such a heavy animal, the humerus is extraordinarily long and slender. The sessile head is strongly compressed from side to side, very convex, and much larger than the glenoid fossa, its articular surface extending onto the base of the greater tuberosity. This tuberosity is heavy and thick, but does not project above the head. The powerful deltoid riclge extends from the tuberosity two-thirds of the way down the shaft. The shaft is unusually slender. I istally it expands laterally to make the two large epicondyles, of nearly equal size. The trochlea is relatively narrow, the internal surface being the narrower, and rising to a high margin; while the external portion is wider, rounded, and has a low margin. The supratrochlear fosia is moderately deep, the anconeal fossa somewhat deeper, but there is no connecting foramen.

(sauklry* figures a radius and ulna, both relatively long lones, and closely apposed; so that there was no possibility of a rotary motion of the forearm. The proximal end of the radius is expanded, so that its articular surface is in contact with the full width of the humeral trochlea on the anterior side. Below, the bone contracts to a molerately slender shaft, and then expands distally into

* Anal. Palacontologie, t. I, p. 5, 1906. 
a heavy club-like distal encl. The ulna has a short hut heavy olecranon process, with a prominent coronoid process. The sigmoicl notch is shallow, but the articular surface expands on both sides. so that it covers the full width of the humeral trochlea on the posterior side. Distally the ulna is not so heavy as the radius.

Inder the name Pyrotherium romeri. Ameghino* figures a carpus and metacarpus, which Tourniert however assigns to Parastrapotherium, prohably $P$. herculeum; and figures a carpus and metacarpus of the same type, hut smaller, which he attributes to Parastrapotherium. I, however, can not see how such a small foot can helong to so large an animal, and feel that, until eridence of direct association is given, it is best not to consider these feet as belonging to Parastrapotherium, but rather to Pyrotherium.

Of the femur I have only the distal end, which, however, corresponds completely with the one figured by (iaudry. It is a long bone, slightly shorter than the humerus. with a small head, set on a short and poorly outlined neck. The greater trochanter is wide and rugose, rising to about the same height as the head. The lesser trochanter is not distinguishable. About the midclle of the shaft there is a powerful third trochanter, which continues as a narrow ridge upward to the greater trochanter, and downward in a similar narrow ridge almost to the outer condyle. tt the proximal end the shaft is greatly flattened, but in the central and lower parts becomes almost circular in section. The two condyles are set wide apart, project considerably behind the posterior face of the shaft. and and are only slightly convex. The trochlea is of moderate width, short, and shallow.

Gaudry outlines a short, heary, rugnse calcaneum which has but a short tuber; a flat navicular; a small cuboid; and an astragulus with only a slight convexity of the

* Bol. Inst. Geog. Argen., t. 18, p. 442, fig. 25, 1897.

† Bul. Soc. Geol. France, ser. 4, t. 5, p. 305, I 905. 
trochlea, and with the navicular facet directed obliquely forward, making an angle of $127^{\circ}$ with the plane of the trochlea, which, as he says, would indicate a semidigitigrade position of the pes.

The following species are distinguished by Ameghino as coming from the Deseado beds: $P$. holmbergi, $P$. troussarti, $P$. lemoinei, $P$. ephebicum, $P$. martiale, $P$. superabile, $P$. insuperabile. The various species are known from the same parts in but a few cases. Their relative sizes are indicated from the following compilation of the measurements given by Ameghino:

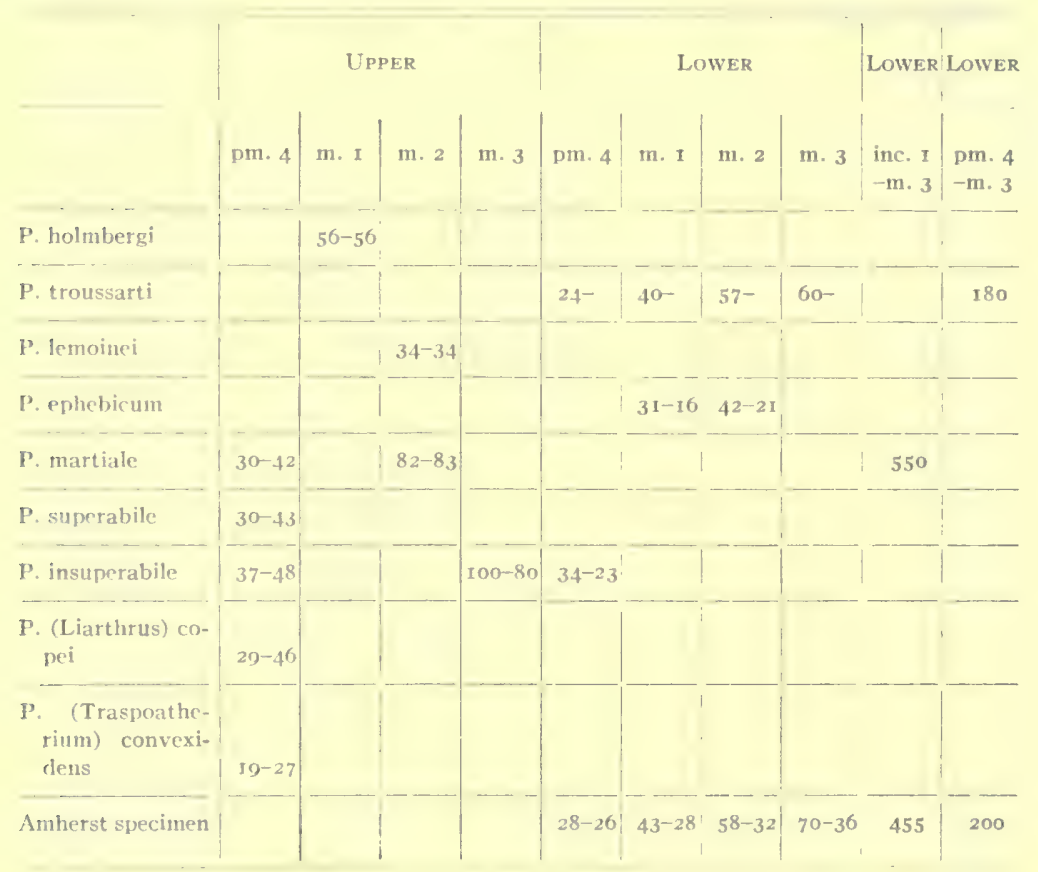

$P$. holmberg $i$ is the type species, and of considerable size, and to it I have assigned my material. In such a large animal, variations in size are to be expected. P. troussarti, as described, is a tenth smaller than P. holmbergi, the only structural character differentiating it being the isolation 
of the pillar in the lower molars, which is a character due to youth; so I have considered it a symonym of $P$. holmbergi. $P$. ephebicum is a much smaller and distinct species, with which I should associate the single upper molar to which the name $P$. lemoine has been giren. $P$. martiale is a large species, distinguished hy the strong development of the cingulum on the internal side of the upper molars, and on the inner side of the lower molars; and by lower premolar 3 being well developed with two roots. $P$. superubile is of the same size as the foreguing, but has the cingulum on upper premolar + (the only touth known) less developed. I should therefore consider it at synonym of $P$. martiule. $P$. insuperabile is the largest species, and is distinguished by the excessive development of the cingulum. Liurthrus is founded on an upper pm. $t$ with a part of pm. 3. hut, as far as I can ieee, doe's not differ in character or size from $P$. holmbersi. Truspoutherium is based on upper premolars which are distinguinhed ly the roots being fused from sicke to side. I think it is an age character and for the present would consider it the same as $P$. holmbergi, probalily the tooth being pm. 3 .

\section{Parastrapotherium holmbergi Ameghino}

P. holmbergi Amegh., I 895, Bol. Inst. Geog. Argen., t. 15, p. 636.

P. holmbergi Amegh., 1897, Bol. Inst. Geog. Argen., t. 18, p. +49.

P. troussarti Amegh., 1895, Bol. Inst, Geog. Argen., t. 15, p. 638.

P. troussarti Amegh., 1897, Bul. Inst. Geog. Argen., t. 18, p. $4+9$.

Liarthrus copei Amegh., 1895, Bol. Inst. Geog. Argen., t. 15, p. 64 I.

Liarthrus copei Amegh., I 897, Bol. Inst. Geog. Argen., t. I8, p. 45 I.

Traspoatherium convexidens Amegh., I 895, Bol. Inst. Creog. Argen., t. 15, p. $6+1$.

Traspoatherium convexidens Amegh., 1897, Bol. Inst. Geog. Argen., t. 18, p. $45^{\circ}$.

Parastrapotherium holmbergi Tournier, 1905, Bul. Sor. Geol. France, ser. 4, t. 5 , p. 305 .

Astrapotherium holmbergi Gaudry; 1906, Anal. Palaeontologie, t. I, p. 5.

To this, the type species. I have assigned all the material we found on the Chico del Chubut. west of Puterto lisser, 
as enumerated under the generic description. The lower jaws belonged to an old individual. The humerus and scapulae were found associated, the femur isolated.

Of the upper clentition, the only available measurements are those of Ameghino for the first molar, and the canine.

Upper dentition, canine, length

Upper dentition, molar 1, length

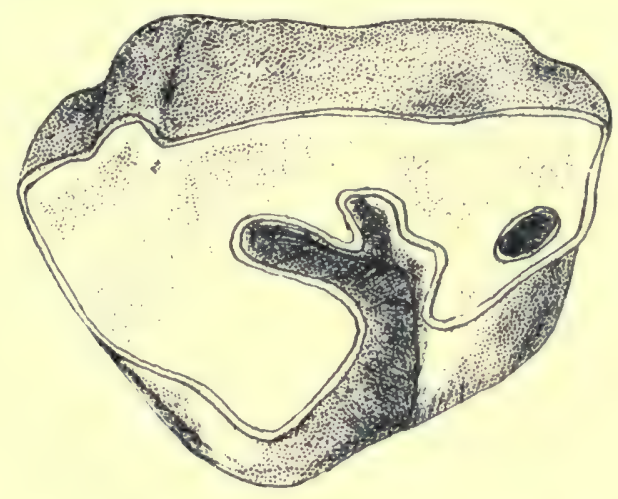

Fig. 103. Upper molar I of the left side-natural size, after Ameghinu.

The measurements of the complete pair of lower jaws which we found are

Lower dentition, length from inc. I to m. 3

Lower dentition, incisor 2, length

$455 \mathrm{~mm}$.

Lower dentition, canine, ant. post. diam. at alveolus $22 \mathrm{~mm}$., width $22 \mathrm{~mm}$.

Lower dentition, canine, trans. diam. at alveolus

$52 \mathrm{~mm}$. $26 \mathrm{~mm}$.

Lower dentition, diastema from c. to pm. 3

$116 \mathrm{~mm}$.

Lower dentition, premolar 4, length

Lower dentition, molar I, length

Lower dentition, molar 2 , length

Lower dentition, molar 3 , length

Height of mandible under molar 3

$28 \mathrm{~mm}$., width $26 \mathrm{~mm}$.
$43 \mathrm{~mm}$., width $28 \mathrm{~mm}$.

$58 \mathrm{~mm}$., width $32 \mathrm{~mm}$.

$70 \mathrm{~mm}$., width $36 \mathrm{~mm}$.

$83 \mathrm{~mm}$.

The scapula is a very long heavy bone, with a narrow blacke, and a high spine which has its upper margin thickened so as to appear like a banister rail. We found one complete scapula and a second incomplete one associated with it, which corresponded in all ways to the first one. 


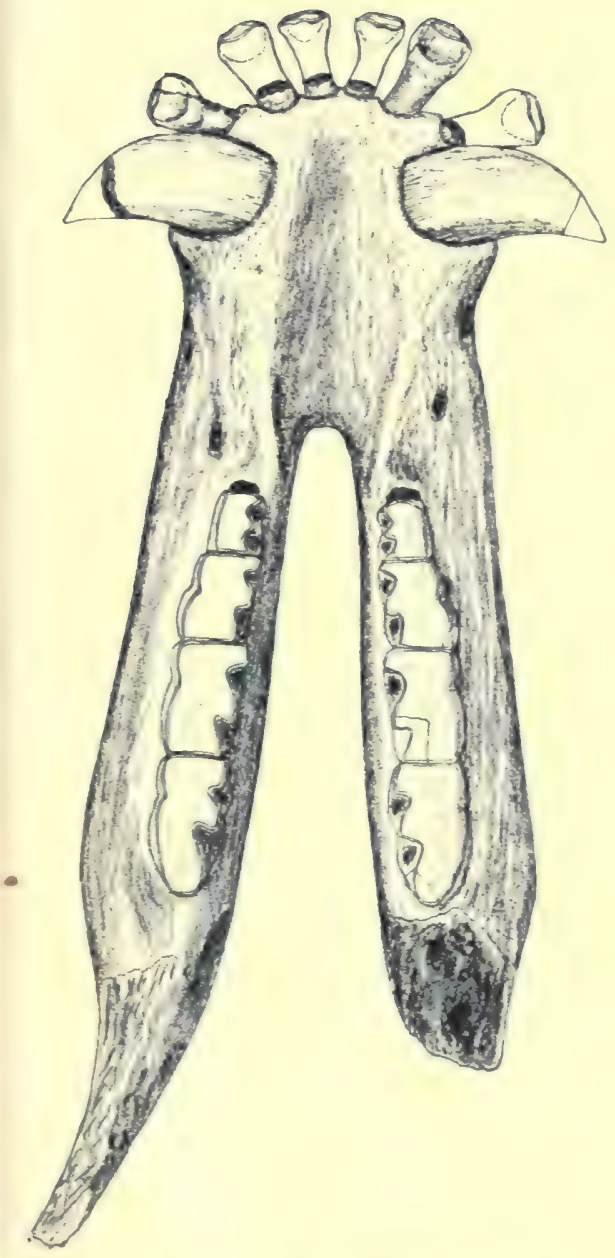

Fig. 104. Lower jaws-I/5 natural size.

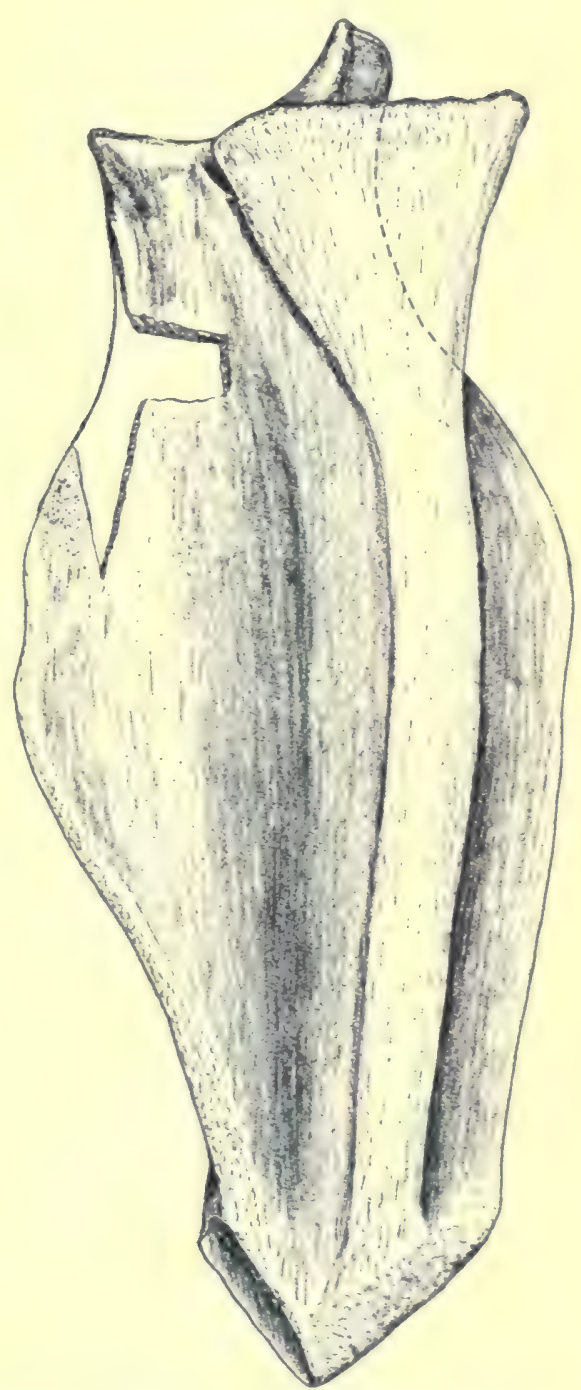

Fig. 105. Dorsal view of right scapula--I/5 natural size. 


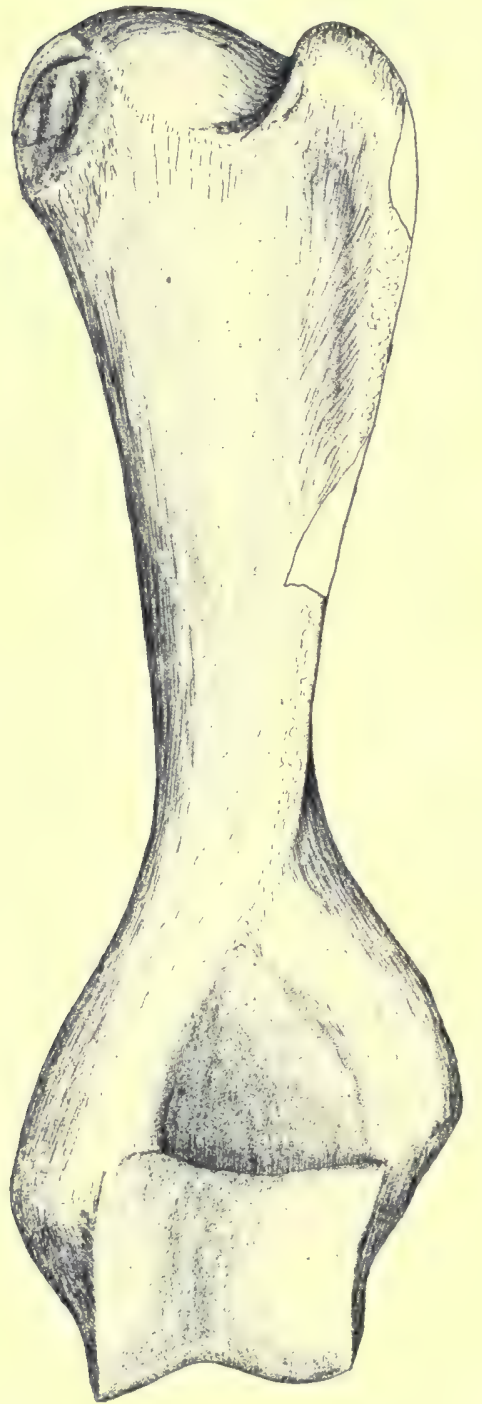

Fig. to6. Right humerus, posterior aspect-I/5 natural size.

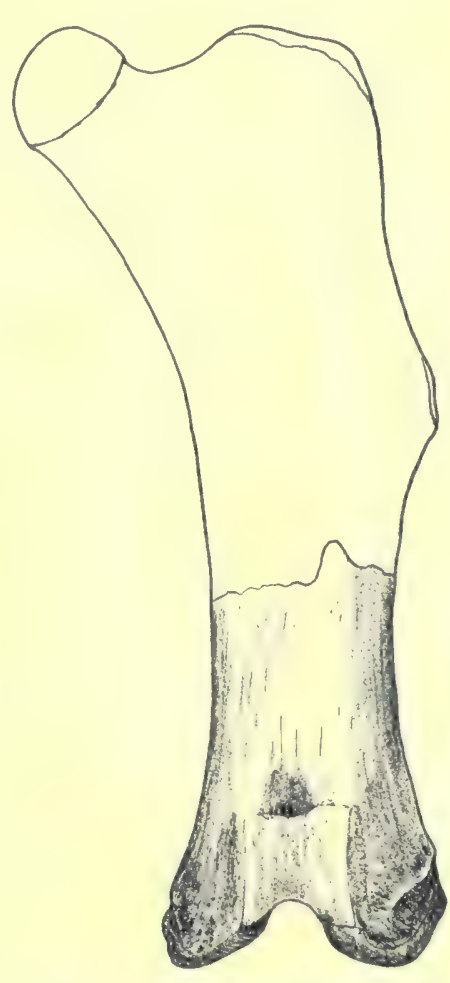

Fig. 107. Left femur, posterior side- - I/5 natural size; outline of upper portion after Gaudry from Astrapotherium magnum. 
The following measurements are taken from specimen No. 3328 :

Scapula, greatest length

$694 \mathrm{~mm}$.

Scapula, greatest width

$283 \mathrm{~mm}$.

Scapula, glenoid fossa, ant.-post. diameter

$130 \mathrm{~mm}$.

Scapula, glenoid fossa, transverse diameter

$90 \mathrm{~mm}$.

Scapula, height of spine

Scapula, width of enlarged margin of spine at the lower end

I $20 \mathrm{~mm}$.

$170 \mathrm{~mm}$.

Scapula, width of margin in middle

$45 \mathrm{~mm}$.

The humerus was associated with the two scapulate mentioned above, and is complete. For such a large animal, its length is excessive, greater than that of the species assigned by Gaudry to $P$. herculeum which species has a skull larger than that of $P$. holmbergi.

Humerus, greatest length

$720 \mathrm{~mm}$.

Humerus, greatest width across proximal end

$248 \mathrm{~mm}$.

Humerus, least diameter of shaft

$78 \mathrm{~mm}$.

Humerus, width across the epicondyles

$220 \mathrm{~mm}$.

Humerus, width of trochlea on distal end

$125 \mathrm{~mm}$.

The femur which Gaudry figures as belonging to Astrupotherium magnum corresponds, as far as the distal end will admit comparison, with the one which we found in the Deseado beds, so that in restroring the outline of the missing parts, I have based it on this 4 . magnmm.

Femur, length (estimated)

$480 \mathrm{~mm}$.

Femur, width of distal end

$135 \mathrm{~mm}$.

Femur, width of trochlea

$57 \mathrm{~mm}$.

\section{Parastrapotherium ephebicum Ameghino}

P. ephebicum Amegh., 1895, Bol. Inst. Geog. Argen., t. 15, P. 639.

P. ephebicum Amegh., 1897, Bol. Inst. Geog. Argen., t. 18, p. 449.

P. lemoinei Amegh., 1895, Bol. Inst. Geog. Argen., t. 15, p. 640.

P. lemoinei Amegh., 1897, Bol. Inst. Geog. Argen., t. 18, p. 450.

Astrapotherium ephebicum Gaudry, 1904, Mem. Soc. Geol. France, t. 12, p.. 15.

Ameghino based this species on a portion of the mandible of an old individual with molars $I$ and 2. Its chief distinction lies in its small size as compared with $P$. holmbergi. Gaudry assigned to this species some upper teeth. IVe 
found no specimens of this species. The following are the measurements of the type according to Ameghino.

Lower dentition, molar $\mathbf{I}$, length

Lower dentition, molar 2, length
$31 \mathrm{~mm}$., width $16 \mathrm{~mm}$.

$42 \mathrm{~mm}$., width $21 \mathrm{~mm}$.

\section{Parastrapotherium martiale Ameghino:}

P. martiale Amegh., I90 I, Bol. Acad. Nac. Cordoba, t. I6, P. 402.

P. superablie Amegh., I901, Bol. Acad. Nac. Cordoba, t. I6, P. 402.

The species seems to have been founded on abundant material, representing an animal of larger size than $P$.

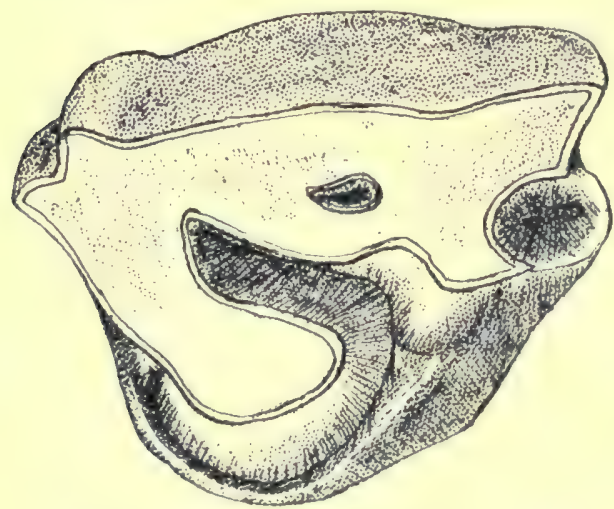

Fig. ro8. Upper molar I of the left side-natural size, after Ameghino. holmbergi, which is distinguished by the greater width of the crowns of the incisors, by straight canines diverging but little, by a strong cingulum on the outer side of the lower molars and the inner side of the upper molars, and by the narrow symphysis of the lower jaws. $P$. superabile was distinguished by a difference in the arrangement of the roots of upper pm. 4, but as the pattern of the crown is the same, as is also the size, I feel that this difference is simply an individual variation. The following measurements are given by Ameghino:

Upper dentition, length from pm. 3 to $\mathrm{m} .3$

$240 \mathrm{~mm}$.

Upper dentition, premolar 4 , length

$30 \mathrm{~mm}$.

Upper dentition, premolar 4 , width

$43 \mathrm{~mm}$.

Upper dentition, molar 2, length

$82 \mathrm{~mm}$.

Upper dentition, molar 2, width

$83 \mathrm{~mm}$.

Lower dentition, length from inc, I to m. 3

$550 \mathrm{~mm}$. 


\section{Parastrapotherium insuperabile Ameghino,}

P. insuperabile Amegh., 1901, Bol. Acad. Nac. Cordoba, t. 16, p. 403.

This is the largest of all the species, and is distinguished by the enormous development of the cingulum on the anterior, inner, and prosterior sides of the upper molars, the same being uninterrupted and so elevated, that the internal crests seem to rise out of a hasin. The following measurements are taken from Ameghino:

Lpper dentition, premolar 4 , length

Upper dentition, molar 3 , length

Lower dentition, premolar t, length
$37 \mathrm{~mm}$., width $4^{8} \mathrm{~mm}$.

$100 \mathrm{~mm}$, width $80 \mathrm{~mm}$.

$43 \mathrm{~mm}$., width $23 \mathrm{~mm}$. 


\section{CHAPTER XII}

\section{Proboscidea}

\section{Suborder Pyrotheria}

THIs suborder was established by Ameghino to receive the peculiar genus Pyrotherim and related forms. These animals are of large size, massive build, with narrow elongated skulls, in which the nasal opening is situated far back, as in animals with a proboscis; with a tiny brain case surrounded by cellular spaces; with the maxillae, palatines, pterygoids and alispenoids developed downward, so that the palatal plane makes a strong angle with the hasi-cranial plane; and with the occipital condyles high up on the back of the skull. Then the first and second upper incisors and the second lower incisors are developed intoenormous fushes with enamel on the anterior sides only. The remaining incisors, the canines, upper premolar I, and lower premolars $\mathrm{I}$ and 2 are wanting; the remaining premolars and the molars being developed into great quadrilateral grinders, each with two transverse crests. The neck is short, the limbs massive and short, especially the lower members of each limb, and the feet were probably five-toed.

The relationship of these forms has been the subject of extended discussion: Ameghino seeing in this genus the ancestors of the Probiscidea, and comparing them with Palueomastodon, Dinotherium and Barytherium, even finding resemblances to Diprotodon; (iaudry concludes that they are not proboscidians; and others have suggested that they were specialized toxodonts. I have prepared the following table of comparisons with Palaeomastodon, a toxodont, and Diprotodon. 


\begin{tabular}{|c|c|c|c|c|}
\hline & PYROTHERICM & PALAEOMASTODON & $\begin{array}{l}\text { ToxodoNT. } \\
\text { NESORIS }\end{array}$ & DIPROTODON \\
\hline I Upper tush & $\begin{array}{l}\text { Inc. I enlarged } \\
\text { Inc. } 2 \text { tush }\end{array}$ & $\begin{array}{l}\text { Inc. I enlarged in } \\
\text { Mneritherium. } \\
\text { Inc. } 2 \text { tush }\end{array}$ & $\begin{array}{l}\text { Inc. I reduced } \\
\text { Inc. } 2 \text { caniniform } \\
\text { tusin }\end{array}$ & $\begin{array}{l}\text { Inc. I tush } \\
\text { Inc. } 2 \text { reduced }\end{array}$ \\
\hline 2 l'pper molars & Bilophodont & $\begin{array}{l}\text { Bilophorlont in } \\
\text { Mastorlon and } \\
\text { Dinotherium }\end{array}$ & Rhinoceros-like & Bilophodont \\
\hline 3 Lower tush & Inc. $2(?)$ & Inc. 2 & Inc. 3 & Ine. I \\
\hline 4. Lower molars & Bilophodont & $\begin{array}{l}\text { Bilophoront in } \\
\text { Masterdon and } \\
\text { Dinotherium }\end{array}$ & Bicrescentric & Bilophodont \\
\hline 5 Nasal opening & Over molar I & Over molar I & Over incisors & IOver diastema \\
\hline 6 Basicranial axis & $\begin{array}{l}\text { Plane of base of } \\
\text { cranium bent up. } \\
\text { makes } 140^{\circ} \text { with } \\
\text { plane of palate }\end{array}$ & $\begin{array}{l}\text { Plane of base of } \\
\text { cranium bent un, } \\
\text { makes } 155^{\circ} \text { with } \\
\text { plane of palate }\end{array}$ & $\begin{array}{l}\text { Plane of hase of } \\
\text { cranium parallel } \\
\text { with plane of } \\
\text { palate }\end{array}$ & $\begin{array}{l}\text { Plane of hase of } \\
\text { cranium parallel } \\
\text { with plane of } \\
\text { palate }\end{array}$ \\
\hline F Pterygoids & $\begin{array}{l}\text { Pterygoids plus } \\
\text { alisphenoids } \\
\text { make great verti- } \\
\text { cal plates }\end{array}$ & $\begin{array}{l}\text { Petrygoids plus } \\
\text { alisphe noids } \\
\text { make great verti- } \\
\text { cal plates }\end{array}$ & Pterygoids normal & Pteryguids normal \\
\hline 8 Jugal & $\begin{array}{l}\text { Takes small part } \\
\text { on glenoid fossa }\end{array}$ & $\begin{array}{l}\text { Takes small part } \\
\text { on glennid fossa }\end{array}$ & $\begin{array}{l}\text { Takes no part on } \\
\text { glennid fosia }\end{array}$ & $\begin{array}{l}\text { Extends to glenoid } \\
\text { f } n=s a\end{array}$ \\
\hline $\begin{array}{l}9 \text { Posttympanic process } \\
\text { squamosum }\end{array}$ & $\begin{array}{l}\text { Surrounds meatus, } \\
\text { and crowds out } \\
\text { tympanic }\end{array}$ & $\begin{array}{l}\text { Surrounds meatus } \\
\text { and crowds out } \\
\text { tympanic }\end{array}$ & $\begin{array}{l}\text { Surrounds meatus, } \\
\text { and crowis out } \\
\text { tympanic }\end{array}$ & $\begin{array}{l}\text { Not surround me- } \\
\text { atus nor crowd } \\
\text { out tympanic }\end{array}$ \\
\hline to Tympanic bulla & $\begin{array}{l}\text { Small, in fl a ted, } \\
\text { hollow }\end{array}$ & $\begin{array}{l}\text { Small, in fla ted. } \\
\text { hollow }\end{array}$ & $\begin{array}{l}\text { Large, in fl a ted. } \\
\text { hollow }\end{array}$ & \\
\hline I I Palatine bones & $\begin{array}{l}\text { Narrow in front, } \\
\text { expanding behind }\end{array}$ & $\begin{array}{l}\text { Narrow in front. } \\
\text { expanding behind }\end{array}$ & $\begin{array}{l}\text { Wide in front, nar- } \\
\text { rowing somewhat } \\
\text { lwethinl }\end{array}$ & \\
\hline 12 Premaxilla & $\begin{array}{l}\text { Crowded out from } \\
\text { forming any por- } \\
\text { tion of palate }\end{array}$ & $\begin{array}{l}\text { Crowded out from } \\
\text { forming any por- } \\
\text { tion of palate }\end{array}$ & $\begin{array}{l}\text { Makes front of } \\
\text { palate }\end{array}$ & Fused to maxilla \\
\hline 13 Antorbital foramen & 2 foramena & 2 foramena & I foramen & I f foramen \\
\hline If Intercellular laminae & Present & Present & None & None \\
\hline 15 Atlas & $\begin{array}{l}\text { Long, has hypo- } \\
\text { physis }\end{array}$ & $\begin{array}{l}\text { Long, has hypo- } \\
\text { physis }\end{array}$ & $\begin{array}{l}\text { Long, no hypo- } \\
\text { physis }\end{array}$ & $\begin{array}{l}\text { Short, no hypo- } \\
\text { physis }\end{array}$ \\
\hline I6 Axis & $\begin{array}{l}\text { Hem ispherical } \\
\text { orlontoid }\end{array}$ & Rounded odontoid & Peg like odontoid & $\begin{array}{l}\text { Odontoid slightly } \\
\text { flattened on top }\end{array}$ \\
\hline
\end{tabular}




\begin{tabular}{|c|c|c|c|c|c|}
\hline & & PYROTHERIUM & PALAEOMASTODON & $\begin{array}{l}\text { TOXODONT, } \\
\text { NESODON }\end{array}$ & DIPROTODON \\
\hline 17 & Cervicals 3-7 & Very short & Very short & Moderately long & Short \\
\hline 18 & Humerus & $\begin{array}{l}\text { Flattened deltoid } \\
\text { ridge with post. } \\
\text { spur }\end{array}$ & $\begin{array}{l}\text { Hattened deltoid } \\
\text { ridge with post. } \\
\text { spur }\end{array}$ & $\begin{array}{l}\text { Rounded no spur } \\
\text { on deltoid ridge }\end{array}$ & $\begin{array}{l}\text { Flattened distally. } \\
\text { tiny spur on del- } \\
\text { toid ridge }\end{array}$ \\
\hline 10) & Radius and Ulna & $\begin{array}{l}\text { Very short and } \\
\text { massive }\end{array}$ & & Moderate length & Fairly long \\
\hline 20 & Fenur & $\begin{array}{l}\text { Flattened, Gr. tro- } \\
\text { chanter low, no } \\
\text { 3rd trochanter }\end{array}$ & $\begin{array}{l}\text { Flattened, Gr. tro- } \\
\text { chanter low, trace } \\
\text { of 3rd trochanter }\end{array}$ & $\begin{array}{l}\text { Rounded, Gr. tro- } \\
\text { chanter high, 3rd } \\
\text { trochanter }\end{array}$ & $\begin{array}{l}\text { Rounded, Gr. tro- } \\
\text { chanter very low, } \\
\text { no } 3 \text { rd trochanter }\end{array}$ \\
\hline 21 & Tibia & $\begin{array}{l}\text { Short and massive, } \\
\text { free from fibula }\end{array}$ & $\begin{array}{l}\text { Short and massive, } \\
\text { free from fibula }\end{array}$ & $\begin{array}{l}\text { Moderate length. } \\
\text { fused to fibula at } \\
\text { upper cnd }\end{array}$ & $\begin{array}{l}\text { Moderate length, } \\
\text { free from fibula }\end{array}$ \\
\hline
\end{tabular}

Still other forms like Amblypoda and Arsinotherium have been suggested as having characters in common with Pyrotherium, and it is clear that, with such a variety of forms, some of the characters must be parallelisms due to a common adaptation, and only one of these varied groups can be the one to which Pyrotherium is related. For myself, I have made comparisons with the Amblypoda and Arsinotherium, and feel that such features as the massive limbs, shape of individual bones, etc., are due simply to the fact that all these are massive animals. In the case of Arsinotherium, there are some characters which are also common to hyracoids and elephants, like the position of various basicranial foramena, the prolongation backward of the jugal and the shape of the palatines. My conclusion is that Pyrotherium is related to the proboscideans, and came from the same stock which gave rise to hyracoids, elephants and Arsinotherium. I think further that Pyrotherium belongs definitely to the proboscidean line.

Referring back to the foregoing table. The development of tushes may be an adaptive character; but in the elepnants it is inc. 2 of the upper and inc. 2 of the lower 
jaw which are so denchered. In Pyrotherium, in the upper dentition, it is also inc. 2 which makes the tush, and inc. I is enlarged as in Mocritherium, and, so far as we know, has not been reduced in later forms as it was in the elephant line. In the lower jaw we have no final evidence which will show whether it is inc. I or inc. 2 which makes the tush; but the lower tush hites against upper inc. 2 and I have considered it to be incisor 2 .

The loss of the teeth behind the tushes is a character to he expected in the development of tushes and gives no data. The bilopholont character of the hack teeth has occurred many times in the animal kingdom and while it may he the inheritance of the early elephants it can not be used as an argument.

The position of the nasal opening looks very murh like that of elephants, hut again is coincident with the development of a proboscis. However, this has not occurred a great number of times in the animal kinglom, and where it has, it takes a variety of forms of moxlification. In $P_{y-}$ rotherium, the modification is of the type in elephants, and elephants only.

A very striking feature is the development of the dental region downward so that the hasi-cranial axis is hent upward, making an angle of ahout ifo degrees. There are other cases of the bending of the hasicranial axis: but in the other ungulates it is a bend downward, the reverse of what we find here and in elephants. To adjust the posterior part of the nasal chamber to this, the pterygoids and the alisphenoids are developed into great winglike plates on either siele. I find this modification of the basicranial axis and of the palatal, ptergenid and alisphenoid bones in no other group but the elephants. In Palaeomastodon it has been developed to a degree so that the angle is about 155 degrees.

The back of the palatine bones is also characteristic, for these begin as narrow pointed bones and behind the 
last molar expand into wide plates, just as in Palaeomastodon (and in no other groups), having the postpalatine foramen opposite or behind the last molar.

The posttympanic region of the squamosum is modified so that this process unites with the anterior squamosal region to crowd out more or less completely the tympanic bone where it should surround the auditory meatus. This feature is common to the elephants, the hyracoids, and the toxodonts, so that I consider it a primitive feature indicative of the ultimate common ancestry of these groups. The tympanic bulla can be compared with that of elephants closely, and has much in common with that of toxorlonts, but in this last group the tympanic is much more highly developed.

The premaxilla bone in Pyrotherium is crowded out, so that it makes no part of the palate, which is a character of elephants, and in contrast to toxodonts or other groups which have been mentioned. There are two antorbital openings as in elephants, and a feature not common, though not unknown. On either side of the brain case are cellular spaces with intercellular lamellae, which are so characteristic of clephants; a confirmatory feature, though in itself not conclusive.

The foramena on the base of the cranium are similar to those on the base of the cranium of elephants, though there are some variations, as for instance, the exoccipital foramen, is isolated in Pyrotherium, but fused with the posterior lacerum foramen in elephants, and other slight variations in position; but, on the whole, the foramena of Pyrotherium are much closer to those of elephants than of any other group. There is also much in common with toxodonts and with hyracoids, as would be expected if they have a common ancestry. There is no suggestion of a marsupial arrangement as would be necessary if related to Diprotodon. 
The atlas of Pyrotherium is peculiar in having a marked hypophysis which is unusual, but is a feature of the atlas of Palacomastodor and Moeritherium. The avis is peculiar in that the odonterid is flattened on the upper side and very short and wide. In this the form is unique. The continuation of the articular surface on the lower side of the odontoid with the articular surfaces of the ant. cotrle's is a feature also of elephants. The remaining cervicals are greatly shortened almost to plates, which is elephantine again, though this short neck is approximated hy Diprotodon, some Amblypods and Arsinotherium, so that it must be in general looked upon as an arlaptive feature, though in its detail it shows again an elephant character.

The upper members of the limbs are longer than the lower, which is common to many massive animals. The humerus is tremendously flattened from front to back, even more so than in any of the animals userl for comparison, though Hattening is a feature of them and of the elephants the most so. With the flattening, the deltoid ridge is prolonged enormously making a crest along the outer side of the lone, which at the lower end rises in a prominent process, as in elephants (also in Diprotodon but in this case the rest of the bone is very different). In addition to this, the supinator ridge is prolonged upward until it almost meets the deltoid, ending in a sharp spur at the top. This spur is more marked in Pyrotherium than in elephants, although they show the same derelopment of the supinator ridge.

The femur has the head much higher than the greater trochanter, which is a feature common to elephants. Diprotodon, Arsinotherium. etc., so that it must he looked upon as an arlaptation. The third trochanter has disappeared, and in elephants, it is lost in the advanced forms, remaining however as a trace in Palaeomastodon.

The tibia is very short and massive and hardly gives any suggestions of relationship, except that it is not fused I I 
with the fibula at the upper end, in which it is in strong contrast to the toxodonts.

While in the table of comparisons numbers $1,2,3,4$, $8,9,10,14,17,19,20$, and 21 may be, in part, or wholly, interpreted as adaptations, and alone would not be at all conclusive of relationship to elephants, numbers I, 5, $6,7,8,1 \mathrm{I}, \mathrm{I} 2, \mathrm{I} 3, \mathrm{I} 5, \mathrm{I} 8$, and $2 \mathrm{I}$ point toward the elephants as the close relatives of the Pyrotheria. In the first series of points there are none which mitigate against associating these two groups, while if the attempt is made to associate Pyrotherium with any group other than Proboscidea there are strong points, and a number of them, which would prevent this association. As a result of the foregoing, together with a feeling which continued handling of the specimens has given me, I can come to no other conclusion than that the Pyrotheria should be placed under Proboscidea.

In his Linea Filogenctica de los Proboscidens, Ameghino assigns to this suborder, or at least puts into the phylogenetic tree, a considerable number of forms from the (asamayor beds, all of them genera with bunodont molars, usually known by but one or wo teeth, such as $A$ smithïoodwardi, Nephracodus, Cephanodus, Paulogervisia, and the better known genera, Carloameghinia, and Didolodus, all of which he makes ancestral to Pyrotherium. So far as known, however, these forms show none of the peculiarities of the Pyrotherium skull or dentition, so that it is difficult for me to see any reason for including them even in the suborder. The genus Carlozittelia, from the upper Casamayor, is in a different position, having an enlarged upper incisor (found isolated) and molars of the bilophodont type. I should include this in the family Pyrotheridae and none of the others. 


\section{Pyrotheriidae Ameghino}

All the forms asignent to this family are supposed to be closely related to Pyrotherium and to have much the same structure. Ameghino has proposed the following genera. Pyrotherium. Parapyrotherium. Richardowenia, Archaeolophus, Propyrotherium.

Parapyrotherium is based on a small molar and a tush which Imeghino first described as Pyrotherium planum, later elevating the suecies to a genus. designated as Porupyrotherium, differentiated by the transierse crests heing low and the valley at either end being blocked by an intertubercular ridge. (iaudry considered that this genus represented either the milk teeth of $P$. romeri, or a variation of that species. I can not see the basis of a new genus in the material.

The genus Richardoweni is based on half of a molar, which has the transverse crest interrupted in the middle. Too little is known of this form to base a valid genus or even to associate it with Pyrotherium.

Archacolophus is founded on a small tush and part of an upper molar, also inadequate material for a genus. It is probably Pyrotherium.

Propyrotherium is a smaller form from the Astraponotus beds, apparently a good genus: the type species heing $P$. saxeum, of considerable smaller size than any of the Deseado species. The distinctive features of the genus can not be given until more material is known.

Carlozitteli is hased on a small form from the (asamayor with narrow molars. An incisiform tush is associated with the molar, which, if correctly associated. would indicate a wide deviation from Pyrotherium, and would probahly be an ancestral form. A second species is reported from the lower Ineseado beds, but I am a little skeptical as to the horizon. 


\section{Pyrotherium Ameghino}

Pyrotherium Amegh., I889, Actas Acad. Nac, Cienc. Cordoba, t. VI, p. 617. Pyrotherium Lydekker, 1894, Anal. Mus. La Plata, Palaeontologia Argentina pt. 3, p. 4 .

Pyrotherium Amegh., I 895, Bol. Inst. Geog. Argen., t. I5, p. 609.

Pyrotherium Amegh., I 897, Bol. Inst. Geog. Argen., t. I 8, p. 44I.

Pyrotherium Amegh., 1902, Anal. Mus. Nac. Buenos Aires, ser. 3, t. I, p. 19-43. Pyrotherium Amegh., 1902, Anal. Mus. Nac. Buenos Aires, ser. 3, t. 1, p. 223-4. Pyrotherium Gaudry, 1909, Anal. Palaeontologie, t. 4, p. I-28.

Parapyrotherium Amegh., 1902, Anal, Mus. Nac. Buenos Aires, ser. 3, t. I, p. 29.

The type species of the genus is $P$. romeri, which is however a rare species, most of the material and the best known belonging to $P$. sorondoi. The Amherst ('ollection contains a skull, complete except that the top of the brain case is crushed in and the parietals lost; a second skull with the full upper clentition but lacking the cranium; four lower jaws; two isolated tushes; the atlas, axis, and crevicals 3 and 4 ; the humerus; the proximal end of the femur; and part of the front foot; all from the Chico del Chubut west of Puerto Visser. Gaudry had upper and lower dentition and the fore and hind limbs except the feet. Imeghino described the upper and lower dentitions and a fore foot, so that with our material we now have a dasis for a fairly complete discussion, the vertebral column being the major part which is still lacking.

The first striking feature is the dental formula. As formerly given, it is inaccurate, there being two great tushes on either side of the upper jaw, instead of one, as described. At first sight, I thought it might be a meristic variation, but both of my skulls show the same arrangement on both sides, and these are the first two skulls which have been found complete to the front end, and neither is by any means a young individual. The dental formula would then read $\frac{2033}{1023}$.

Upper incisor $I$ is a rootless, permanently growing tush about a fourth smaller than inc. 2, but of the same 
character, being oval in cross section and having enamel on the front face only. These first incisors are directed downward, so that their ends stand between and very slightly in front of the second incisors. The end of each is worn bluntly round in contrast to the beveled end of inc. 2. The second incisor is larger, rootless, and permanently growing, with a hollow hase, enamel on the front face only, and oval in cross section. Both these teeth have a layer of cement on them. extending some distance beyond the alveolus. The tips are worn in a long bevel on the posterior side, very much as is the case on the incisors of rodents.

The third upper incisor, the canine, and premolar I are lacking, a long diastema occupying their place, out of which they have been crowded by the derelopment of the enormous root of inc. 2, which extends $150 \mathrm{~mm}$. and more back into the jaw. P. romeri is distinguished from the others by pm. I being present.

The teeth of the upper premolar-molar series have their crowns expanded, and the two series of either side have moved toward each other; until in front they are in contact while in the rear they are only $50 \mathrm{~mm}$. apart, narrowing the palate in a unique manner, and giving the impression that the palate is mostly a grinding surface. The premolars are completely molariform and the whole series is at an advanced stage of specialization.

Premolar 2 is three-rooted, with a triangular crown on which are three mamma-like tulercles, the larger one in front, and two behind. As the crown is worn, these unite into a flat, grinding surface, surrounding a central pit which opens behind. Premolars 3 and $t$ and all the molars are large, four-rooted, quadrilateral teeth, each with two transverse crests running clear across the crown, and with a small cingulum across the anterior margin. Before they are worn, the top of each crest is tuberculated, and the cingulum is crenulated. In wearing, the anterior face 
of each crest is ground down; so that instead of the crown wearing to a level surface, it retains throughout life two oblique grinding surfaces.

The lower dentition is more reduced than the upper. When in position, the tips of the two lower tushes diverge, so as to come in contact with the tips of the second upper tushes, from which I conclude that the lower tush is the second, rather than the first incisor, the latter having been lost when the second became enlarged as was the case in elephants. This lower tush has the same oval cross section, enamel on the front face only, and beveled tip as the corresponding upper incisor; but, in the same individual, is somewhat longer and slenderer. When isolated, however, it is difficult to tell whether one is handling a small upper tush or a larger lower one.

The remaining incisors, the canine, the first and the second premolars are wanting, and their place is taken by a small diastema. The lower premolars and the molars are similar to those of the upper jaw, except the cingulum is on the posterior margin, and the wear is on the posterior face of each transverse crest.

The skull is very long and narrow, with wide and deep zygomatic arches. The nasal opening is moved back from the front of the snout to just opposite the orbit, leaving a long, narrow, but heavy snout, made up mostly of the premaxillae, on the anterior end of which is an oval boss, which must have served as an attachment for muscles. With the tushes developed so as to bite against each other, as in a gnawing animal, I can not see any possibility for the development of a pendant proboscis, but think that the snout must have been developed more like that of a pig, but probably to a greater degree. The premaxillae are long and heavy, and prolonged backward to contain the roots of the great tushes; but these bones are not developed on the palatal side of the snout at all. The maxillae are also massive, carrying the premolars and molars, 
and extending forward to the bases of the tushes. They have developed downward so as to carry the plane of the palate far below the plane of the basicranium, and causing the upward fend in the basicranial axis, which is so characteristic of elephants. This bend leaves the occipital condyles a full fext alwere the plane of the teeth. The maxilla extends upward so as to bound the major part of anterior margin of the nasal opening, and of the orbit, which latter opening is small and directed forward. The zygomatic process is large and makes a considerable portion of the arch. The jugal is a broad tlat bone making up most of the zygomatic arch and extending back so as to take a small part in making the glenoid fossa, as in elephants.

The top of the brain case was crushed in before the burial of the animal, the anterior part being present. and about to mm. below its normal position, hut the parietal region having been lowes, expesed the brain cavity, the ear chamber and some of the cellular vacuities. The nasal bones are long and light in build, and are pushed back so that they lie between the pestorbital processes of the frontals. The frontals were united medianly, and prolonged on either side of the nasals to make the postorbital processes. The back margin of the frontals is broken away. The parietals are lest. hut it is apparent that there was a short sargittal (rest. From the middle, high lambdoidal crests extend to either side, and become continuous with the upper margins of the zygomatic arches. The posterior face of the skull slope's back from the lambdridal crests for a considerable distance, down to the moderatesized foramen magnum.

The squamosum is a large bone, with the lambdoidal crest and the extension of the zyenmatic arch on its upper surface. It carries the major part of the glenoid fossa. Behind the auditory meatus is a large post-tympanic portion which extends down and unites with the pretym- 
panic portion, completely inclosing the opening of the ear and crowding the tympanic from being exposed on the side of the skull. There is a very short paroccipital process, and this posterior portion of the squamosum is the part which resembles that of elephants, hyracoids and, to some extent, Toxodontia. There is, however, no cavity in the squamosum as in toxodonts generally. The tympanic bulla is small, but little swollen, and hollow. It is quite exactly like that of probocideans. The basioccipital is fused to the exoccipitals. The occipital condyles are very high above the plane of the teeth, are set wide apart, and are cylindrical bosses which would not allow a free movement of the head laterally, but only in the up and down direction. This last is again a feature of the elephants. The pterygoid bone is greatly enlarged to compensate for the bend in the basicranial axis, and the pterygoids, tegether with the alisphenoids, make broad plate's bounding either side of the posterior nasal chamber, exactly as in Palueomastodon. 'The palatal bone's are slender in front, and broaden toward the rear, again, as in elephants.

On the interior of the brain case is the cavity for the brain which indicates that this organ was of diminutive size, measuring about $150 \mathrm{~mm}$. in length by $50 \mathrm{~mm}$. in width at the widest part. It indicates a brain with very small cerebral hemispheres, which, however, had a swollen posterior margin, a larger cerebellum, and a wide medulla oblongata. The impression which I obtained of this brain is strikingly like that given for Palaeomustodon. On either sicle of the brain cavity are a couple of racuities, apparently for lightening the weight of the skull. At the inner end of the auditory meatus is a large ear chamber, divided into a smaller anterior or cochlear portion, and into a larger posterior ear chamber proper.

In figure I09, I have placed a diagram of the base of the skull of Pyrotherium, along beside that of Palaeomastodon, for comparison of the basicranial foramena. The 


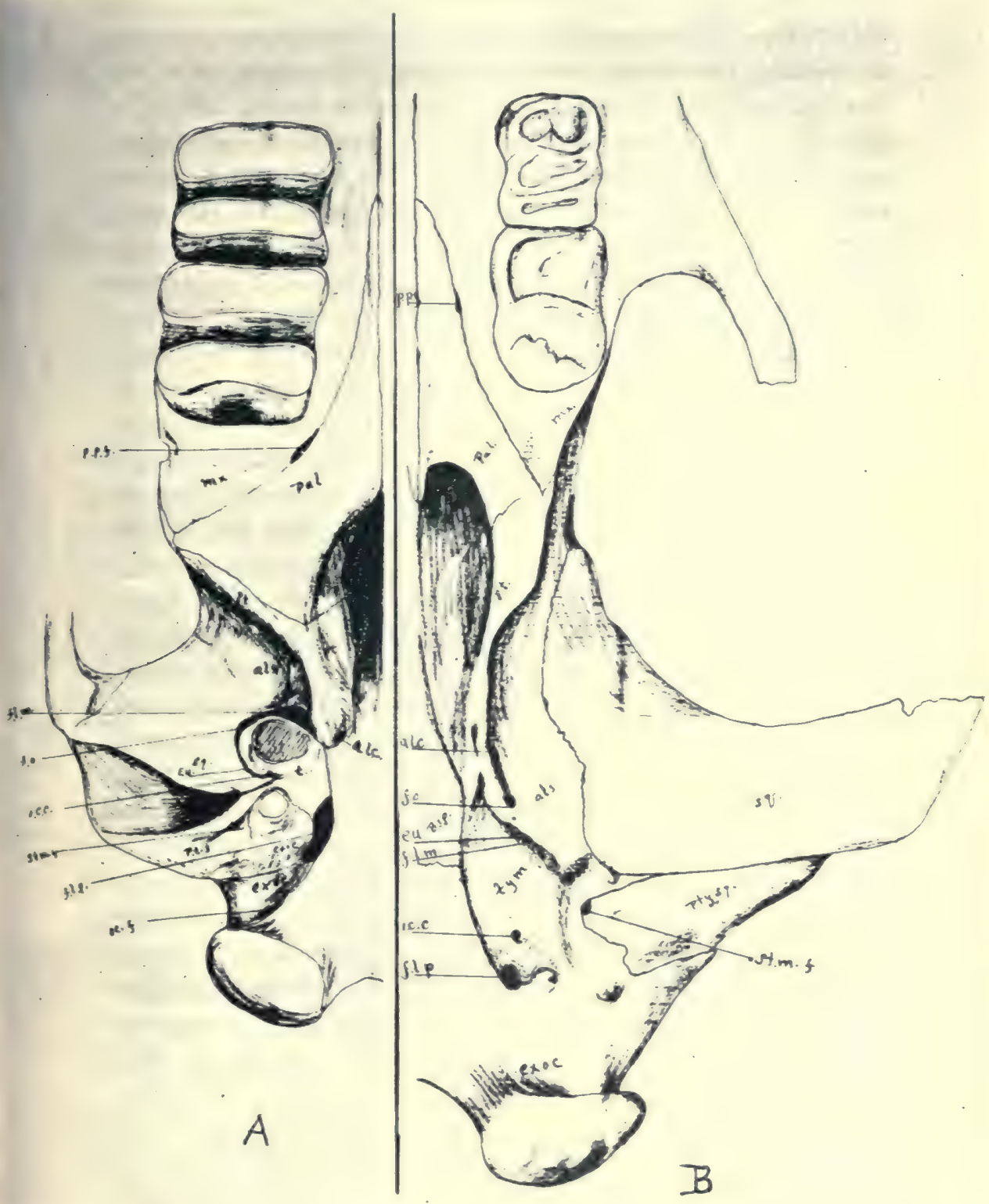

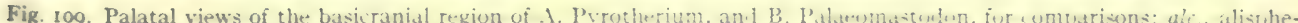

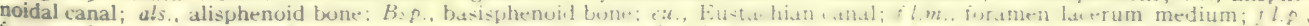

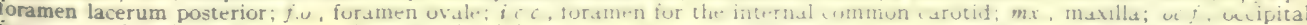

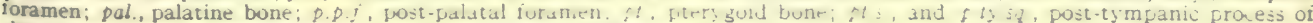
the squamosum; sq. squamosum; st.m.j, stylomistuid fursmen. 
skull of Palaeomastodon is somewhat more elongated, especially in the posterior part. In both, there are two antorbital foramena; the postpalatal foramena of Pyrotherium are a trifle further back, but this palatal region in both is of the same type which is peculiar to elephants and Pyrotherium. In Pyrotherium the condylar foramen is separate, while in elephants it is fused in with the foramen lacerum posterior. This latter foramen in both cases is situated just back of the tympanic, and in Pyrotherium is of considerably larger size than in Palaeomastodon. The foramen lacerum medium is in front of the tympanic and in Pyrotherium appears considerably larger, mostly because it is under the margin of the tympanic in Palaeomastodon. The foramen for the internal common carotid in Palueomastodon pierces the tympanic bone just to the inside of the middle line, while in Pyrotherium it is on the outer margin of the tympanic. The Eustachian canal is on the external border of the tympanic in both cases, but in Pyrotherium it is further back. The foramen ovale of Palaeomastodon is in the posterior part of the alisphenoid bone, but with the shorter alisphenoid of Pyrotherium, this foramen is pushed back to the posterior margin of the bone. In both cases, the alisphenoidal canal starts under the base of the fused alisphenoid and pterygiod, and opens into the orbit. The stylomastoid foramen of Pyrotherium is situated further out than in the case of Palacomastodon. The fusion of the postympanic portion of the squamosum is, in Palaeomastodon, much further advanced than in Pyrotherium, so that the passage to the ear is not apparent in the basal view of the former, but makes a considerable notch on the under side of the skull of Pyrotherium.

The mandibles are excessively thick and heavy, being united at the symphysis, which extends back to the front of the second molar. The ascending rami are prolonged backward, but do not rise above the level of the articulation. 
The atlas is a massive vertebra with the anterior cotyles deeply excavated, especially on the upper side, so that, as Gaudry suggested, the head must have been carried low. The flat posterior cotyles face obliquely downward. The neural arch is light and without a spine or an opening for the vertebral artery. The basal portion of the lune, however, is excessively heary and thick; the socket for the odontoid process not reaching to the middle of the basal bar. The neural canal is oral in section, being a good deal wider than high, and of small size. The transverse processes are short, heary projections, adapted to receive heary muscles. On the ventral surface there projects from the posterior margin a strong hypophysis, which, as Gaudry has pointed out, is unusual, but which is a character of the atlas of the Palaeomastodon.

The axis is a short, heary bone, with the anterior cotyles facing obliquely upward, a small neural arch, no spine, and with a thick odontoid process, which has the form of a quarter of a hemisphere set onto the front of the centrum.

Cervicals 3 and 4 are very short vertebrae with light neural arches and no spines. The neural canal is fully three times as high as wide. Thus it is entirely evident that the neck of Pyrotherium was extremely short, as is the case with elephants, which alone would not be significant, but coincides with many other elephant features. Gaudry described a lumbar vertebra which is also a short. heavy bone. Otherwise the vertebral column of Pyrotherium is unknown.

The distal end of the scapula is described by Gaudry as indicating a short, heary bone, with the glenoid carity compressed so as to be about twice as long as it is wide. The coracoid is a short, blunt process. The spine was broken off, but enough remained to indicate a moderately high spine, prolonged toward the humerus, and bent somewhat forward. 
The humerus is a very characteristic bone, short and stout, but greatly flattened from front to back. It has a large sessile head, which is strongly convex, and projects internally over the margin of the shaft. The external tuberosity is large and rugose but does not project above the level of the head. The deltoid ridge is shifted to the external side of the bone, and makes a long, muscular ridge, while on the opposite external margin is a second ridge, and between the first and second ridges a long furrow or trough is inclosed. These terminate just below the middle of the bone in roughened bosses, which all but meet. The epicondyles are large and give the excessive width to the bone. The external condyle is prolonged upward and ends in a spur. The trochlea is of moderate width and gently undulated. The supratrochear fossa is only slightly depressed, and the anconeal fossa is likewise shallow. The bone has no exact counterpart, but is similar to that of Moeritherium and Palaeomastodon, but in each case is more flattened and has the external ridges more developed.

Gaudry describes the radius and ulna. They are ridiculously short, and very massive. The ulna is stout with a massive olecranon which is directed well toward the rear. The sigmoid noteh is shallow, the coronoid process short, and the articular area expanded so that the ulna covers the whole of the posterior of the trochlea of the humerus. The upper end of the radius is compressed antero-posteriorly, but distally it expands into a heavy bone. Its upper articulation is expanded, so that it comes in contact with the full width of the anterior portion of the trochlea of the humerus.

The carpus and front foot are of questionable association. Ameghino described a front foot as $P$. romeri, and later Tournouer assigned this foot to Astrapotherium. However, I have seen no reason to think it belongs to Astrapotherium, being far too small, and so would for 
the present consider it as belonging to Pyrotherium. We found a couple of metapodials evidently belonging to the foot as described. This carpus is of the primitive type, the scaphoid and luna being large and receiving the radius; while the pyramidal is smaller, low and broad and received the ulna. The trapezium is larger than usual, being elongated and standing out from the trapezoid, and supporting a reduced first metacarpus.

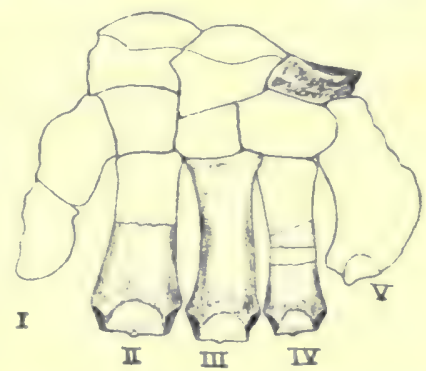

Fig. IIn. Left carpus and metacarnus, cultines aiter Tournouer-1; 5 natural size.

The trapezoid is also large and almost square in outline. The magnum is smaller and considerably flattened. The unciform is very large. These last three mentioned carpals carry the three medium metacarpals which are quite normal and seem to have carried most of the weight of the animal. Metacarpus l'articulates on the outer side of the unciform. It is a massive nodular bone with but a tiny articulation for the phalanx, which seems on this toe to have been reduced. Metacarpals IV, III, and II are short, stout bones, flattened from front to back, and enlarged at either end. On each, the trochlea extends well onto both the dorsal and palmar surfaces, thus giving the toes a considerable range of movement, and indicating at least a semidigitigrad mode of walking.

Of the pelvis, the ilium is known as a hroarl, heary bone with the acetabulum facing down. The hind limb is considerably longer than the front, and approximately pillar-like. The femur, as compared with the humerus, is quite a little longer, though, as femora go, it is not a long bone. The rounded sessile heard stands high ahove the blunt, thick greater trochanter; the digital fossa is barely indicated; the rotular trochlea is short; the two condyles are subequal in size and set close together. The patella is short and nodular. The tibia is short and very 
heavy. The fibula is free its entire length and is a rather heavy bone. The astragulus is a lens-like bone with the trochlea but slightly convex, and the navicular facet directly below it, indicating a rectigrade foot.

Ameghino established the following species, $P$. romeri, $P$. sorondoi, $P$. giganteum, $P$. crassidens, $P$. trilophodon, $P$. pluteum. This is a very considerable number of species of such a large type to occupy a limited region. Gaudry has lumped them all under species $P$. romeri. This, I think, is too drastic and I would find at least two species. It is true that there is great individual variation in such large animals, due to age, food supplies and individual vicissitudes; but where there is a difference of dental formula or a structural divergence I should consider these as specific in character.

The type species is $P$. romeri (later spelled romeroi) which was based on a first and second upper premolar and an upper tush, all of smaller size than $P$. sorondo $i$ and differing from all the others described in having pm. I present. Gaudry suggests that this may be the milk dentition but there is no evidence as yet to settle this, so I have left this species standing. Most of the material found by Ameghino, by Gaudry and by our party belongs to the type described as $P$. sorondoi, which is somewhat larger than $P$. romeri, and lacks pm. I in the upper jaw. This then is the usual species and to it belongs most of what is known. It varies some in size but the characters are very uniform. P. giganteum is based on the root of a large tush, 90 by $70 \mathrm{~mm}$. in cross section, which Lydekker associated with $P$. romeri, and which Ameghino later took as the type of a new species. I can see in this only a large individual of $P$. sorondoi. $P$. crassidens is based on a last lower molar 90 by $80 \mathrm{~mm}$. in diameter. It seems to me to be an upper molar and no larger than m. 2 in either of my skulls. P. trilophodon is based on a lower pm. 3, which, in every way, resembles the corresponding tooth 
in lower jaw of $P$. sorondoi. $P$. pluteum is based on three lower teeth of smaller size than the typical $P$. sorondoi, but the difference is small and there are no structural features accompanying it: $s$ I consider it simply a smaller individual of $P$. sorondoi. In the generic discussion, Parapyrotherium plenum was also ascigned to $P$. sorondoi.

\section{Pyrotherium romeri Ameghino}

P. romeri Amegh., I889, Act. Acad. Nac. Cienc. Cordoba, t. VI, p. 618.

P. romeri Lydekker, in part, 1894 , Anal. Mus. La Plata, Palacontologia Argen., t. III, supplement, p. 4 .

P. romeroi Amegh., 1894, Bol. Inst. Geog. Argen., t. 15, p. 6I 2.

P. romeroi Amegh., 1897, Bol. Inst. Geog. Argen., t. 18, p. $4+2$.

P. romeroi Amegh., I902, Anal. Mus. Nac. Buenos Aires, ser. 3, t. 1, p. 32.

P. romeri Gaudry, in part, I909, Anal. Paleontologie, t. 4, p. 2 I.

This species is characterized by the presence of $\mathrm{pm}$. 1 which is absent in other species. The tooth is of fair size, two-rooted, narrow in front and has a narrow rim of enamel around it; and measure's $22 \mathrm{~mm}$. long hy it mm. wide. The second premolar is $30 \mathrm{~mm}$. long by $33 \mathrm{~mm}$. wide. A lower tush is also associated with these two teeth and is of smaller size than in the following species. heing at the alveolus border to mm. hy $29 \mathrm{~mm}$. in cross section.

\section{Pyrotherium sorondoi Ameghino}

P. sorondoi Amegh., 1 894, Bol. Inst. Geog. Argen., t. 15, p. 6 I 3.

P. sorondoi Amegh., I 897, Bol. Inst. Geog. Argen., t. 18, p. 443.

P. sorondoi Amegh., 1902, Anal. Mus. Nac. Buenos Aires, ser. 3, t. 1, p. 30.

P. sorondoi Amegh., 1906, Anal. Mus. Nac. Buenos Aires, ser. 3, t. 8, p. 33 I.

P. romeri Lydekker, in part, 1894, Anal. Mus. La Plata, Paleontologia Argentina, t. III, supplement, p. 4 .

P. romeri Gaudry, in part, I909, Anal. Paleontologie, t. 4, p. 2 I.

P. giganteum Amegh., 1897, Bol. Inst. Geog. Argen., t. 18, p. 47 .

P. crassidens Amegh., I902, Anal. Mus. Nac. Buenos Aires, ser. 3, t. I, p. 34.

P. planum Amegh., 1897, Bol. Inst. Geog. Argen., t. 18, p. 446 .

Parapyrotherium planum Amegh., 1902, Anal. Mus. Nac. B. A., ser. 3, t. I, p. 29.

P. trilophodon Amegh., 1902, Anal. Mus. Nac. B. A., ser. 3, t. I, p. 33.

P. pluteum Amegh., I901, Bol. Acad. Nac. Cienc. Cordoba, t. 16, p. 386.

P. pluteum Amegh., I902, Anal. Mus. Nac. Buenos Aires, ser. 3, t. I, p. 29.

The species varies in size and in the proportionate development of the tushes as would be expected in a large 


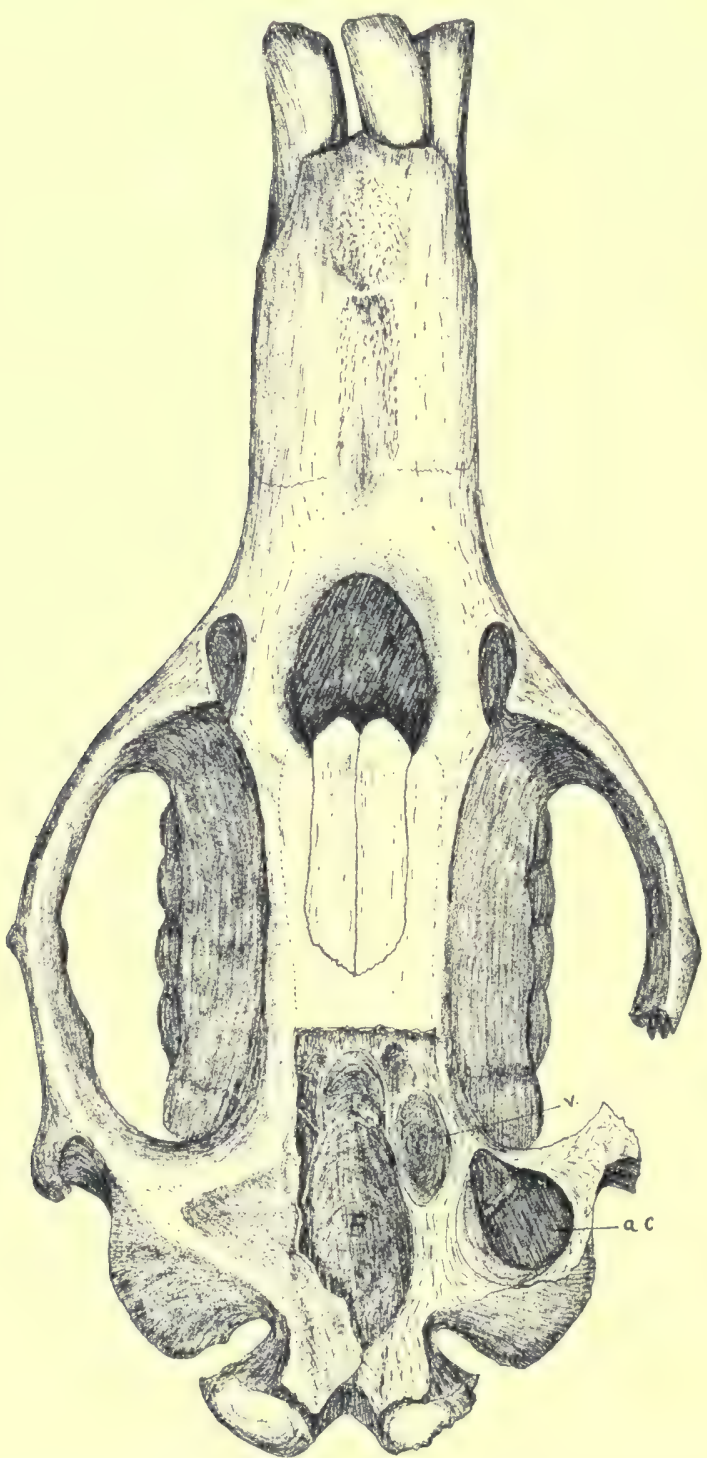

Fig. IIr. Top of the skull-I/5 natural size; Mate to in 1 on the left side is represented by an alveolus but the tooth had fallen out before the death of the animal; $a . c$., ear chamber; $B$, brain case; $\boldsymbol{V}$, vacuities in the bone. 


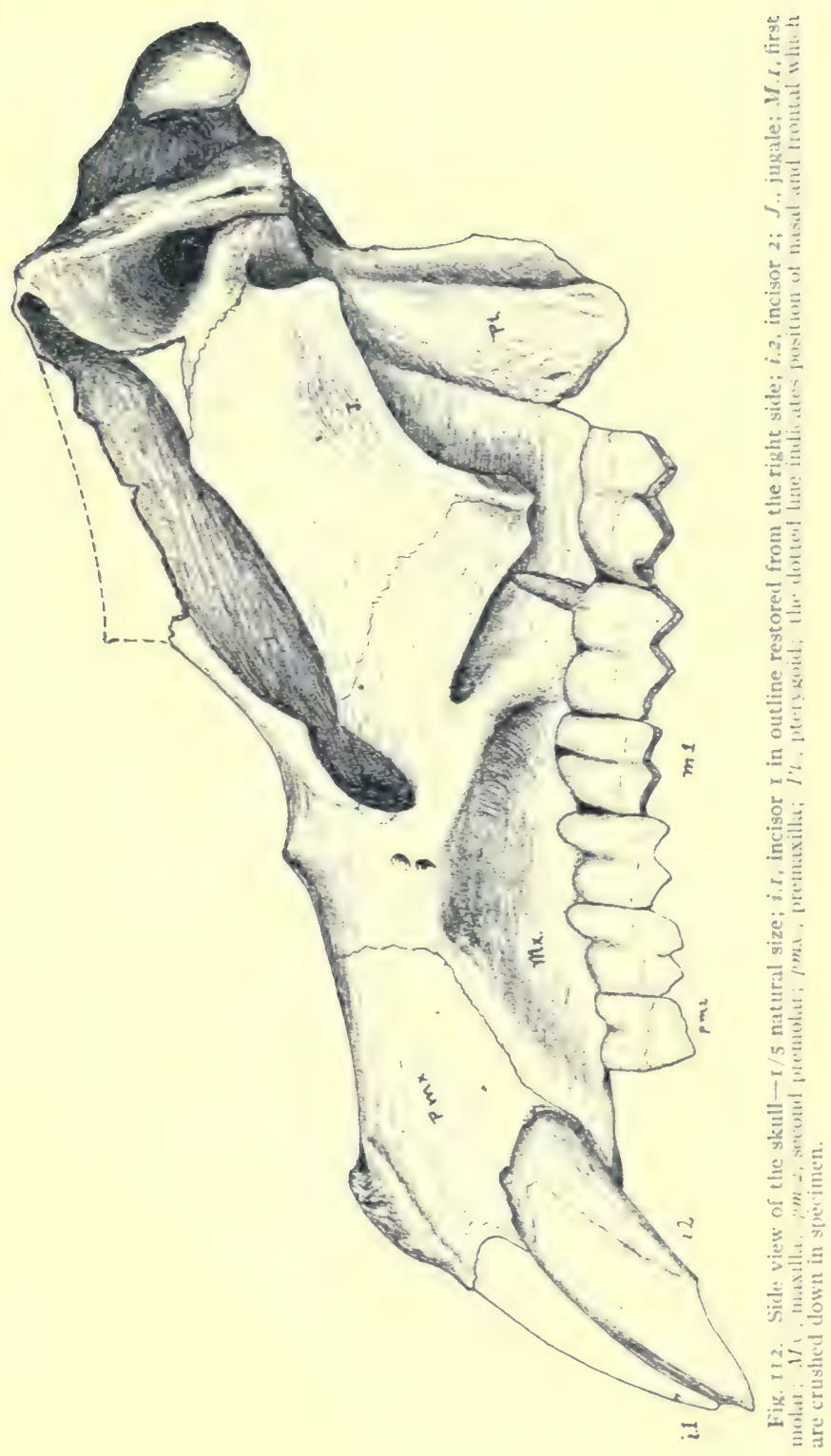


and slow-growing animal. Most all of the material found hy any of the collectors falls clearly into this species. ()ur specimens all came from the (hico del Chubut, west of Puerto Visser, which point is about 250 miles north of the locality where Gaudry's material was found.

The general features of the skull have been given under the generic description. The difference between this and the preceding species lies in the absence of pm. I, and the somewhat larger size. Both of our major specimens are mutilated in places; and as the better skull was found with only the zygomatic arch exposed, we conclude that the parts missing were lost before burial. On the lower jaw the edges of some of the teeth were cracked off, and both the ascending rami are lacking, both things having happened leefore burial, this specimen being found well in the bank and never exposed to weathering. It appears as if the carcasses of the animals lay some time before being buried by the sediments. The scattered condition of all the finds indicates the same thing. The head of our femur is still marked by the teeth which cleaned the meat from the bone. The frequency of isolated tushes indicates that many jaws originally containing them have been either chewed to pieces or weathered away before burial. I do not think all the tushes found originally belonged to the lower jaw (Gaudry reports 18 tushes, all lower); for the upper and lower tushes when isolated are so much alike that it is difficult to distinguish them.

The size of the skull is indicated by the following measurements:

SPECimen No. 3207

Length from inc, I to occipital condyles

$720 \mathrm{~mm}$.

Length from front of premax. to nasal opening

$225 \mathrm{~mm}$.

Length of boss on premaxilla

$77 \mathrm{~mm}$.

Length of nasal opening at top

$80 \mathrm{~mm}$.

Width of nasal opening at top

$88 \mathrm{~mm}$.

I.ength from premax. to lambdoidal crest

$540 \mathrm{~mm}$.

Width across zygomatic arches

$350 \mathrm{~mm}$.

Width across frontal bones

$90 \mathrm{~mm}$.

'Transverse diameter of the snout

$115 \mathrm{~mm}$. 


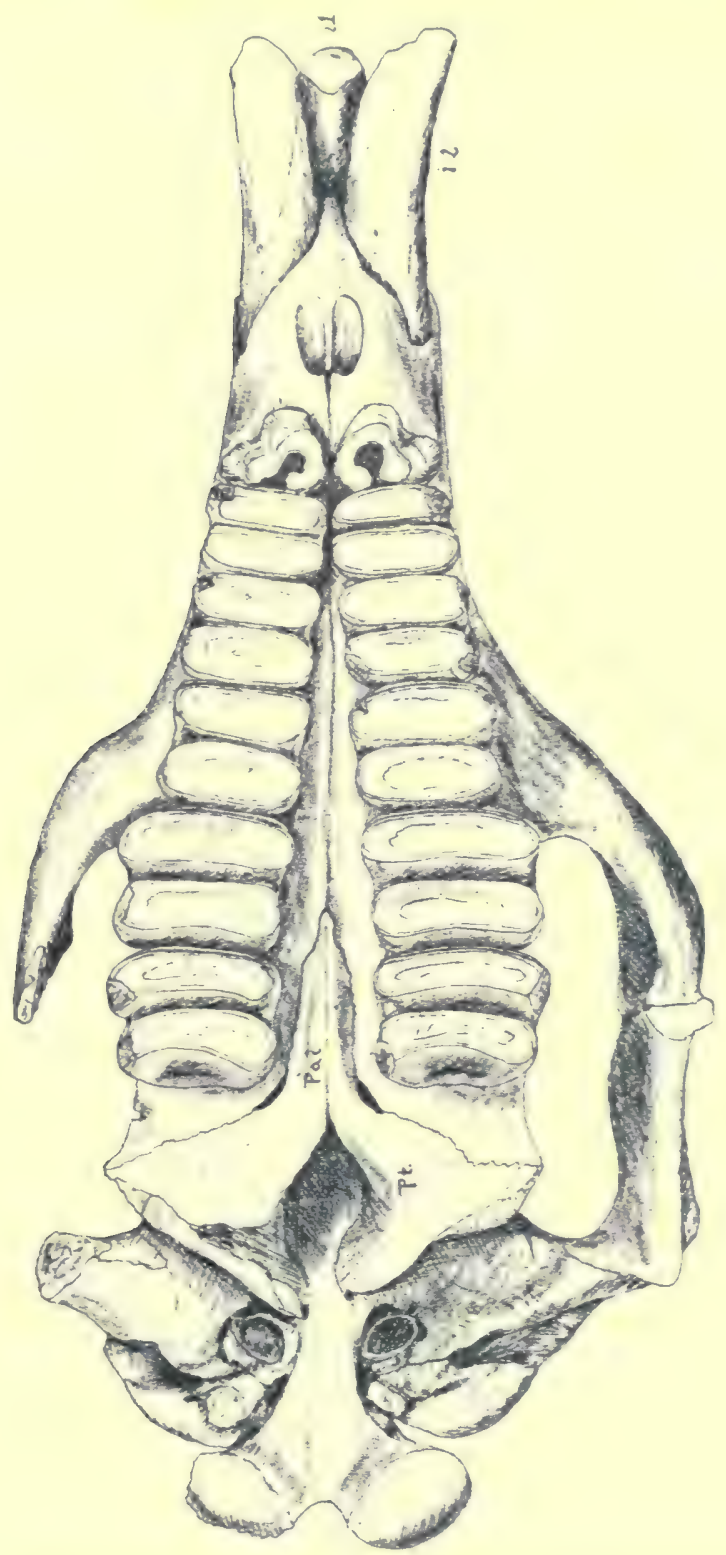

Fig. 113. Base of the skull-1/5 natural size; i.t, incisor the right side grown over toward the center as its mate is wanting; $i .2$, incisior 2; Pal., palatinum; Pl., pterygoid. 
The lower jaws were associated with the above skull, and are complete to behind the third molars on both sides. They are very short and heavy, especially in the anterior portion, the symphysis extending hack to opposite the middle of the second molar. The height under molar 3 is $150 \mathrm{~mm}$. See frontispiece.

From the upper dentition, I give the measurements of my two chief specimens, together with those given by Ameghino for his type of $P$. sorondoi, and the figures given by ( iaudry; from which may beseen the amount of variation which individuals may show.

I'Pper Dentition

Total length, inc. 1 to $\mathrm{m} .3$

Inc. I, length above alveolus Inc. I, antero-posterior diam. Inc. I, transverse diam.

Inc. 2 , length ahove alveolus Inc, 2 , antero-posterior diam. Inc. 2 , transverse diam.

Premolar 2, length

Premolar 2, willth

Premolar 3, length

Premolar 3, width

Premolar 4, length

Premolar 4, width

Nolar I, length

Molar I, willth

Molar 2, length

Molar 2, width

Molar 3, length

Molar 3 , width

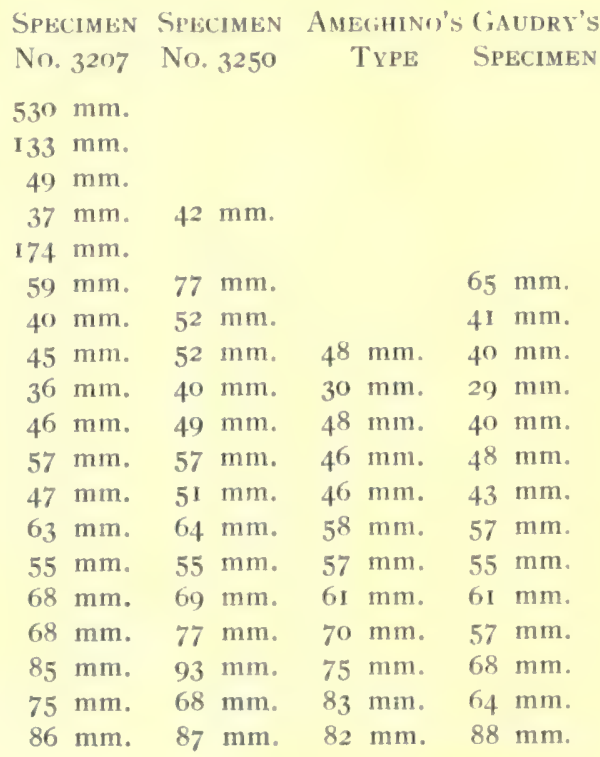

For the lower dentition, I give the figures which Ameghino records for his $P$. sorondoi, those given by (iaudry for his $P$. romeri, and the measurements of specimen No. 3207. The tushes in the lower jaw I would designate ats incisors 2 ; because when the jaws are closed these diverge and their tips bite against the tips of the upper incisors 2. The first incisor seems to have been gradually lost and 
no space left for it in the front of the mandible, just as it was reduced and lost in the development from Moeritherium to Polymastodon or equivalent types.
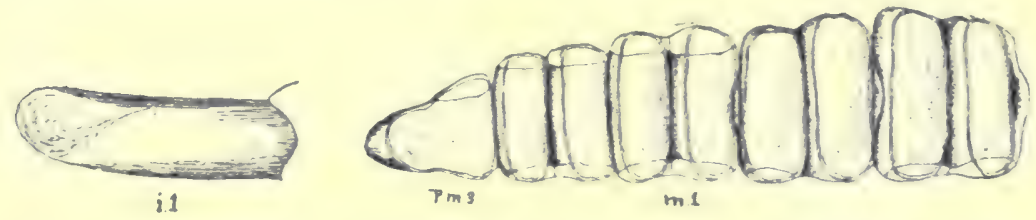

Fig. I14. Lower dentition-I/5 natural size; edges of teeth broken ofi in my specimen are indicated in outline.

LoNer Dentition

Incisor 2 to molar 3 , length Premolar 2 to mular 3, length Inc. 2, length above alveolus Inc. 2, antero-posterior diam. Inc. 2, transverse diam.

Premolar 3, length

Premolar 3, width

Premolar 4, length

Premolar 4 , width

Molar $\mathrm{I}$, length

Molar I, width

Molar 2, length

Molar 2, width

Molar 3 , lenyth

Molar 3 , width

\begin{tabular}{|c|c|c|}
\hline $\begin{array}{l}\text { SPECIMEN } \\
\text { Nu. } 3207\end{array}$ & $\begin{array}{c}\text { AMEghiNo's } \\
\text { TVPE }\end{array}$ & $\begin{array}{l}\text { S GATDRY'S } \\
\text { SPECIMEY }\end{array}$ \\
\hline $510 \mathrm{~mm}$. & $5 t^{\circ} \mathrm{mm} . *$ & $415 \mathrm{~mm}$.* \\
\hline $325 \mathrm{~mm}$. & $280 \mathrm{~mm}$ & $272 \mathrm{~mm}$. \\
\hline $133 \mathrm{~mm}$. & $188 \mathrm{~mm} .^{*}$ & $168 \mathrm{~mm}$ \\
\hline $55 \mathrm{~mm}$. & $60 \mathrm{~mm}$ & $66 \mathrm{~mm}$ \\
\hline to $\mathrm{mm}$. & $36 \mathrm{~mm}$. & $44 \mathrm{~mm}$. \\
\hline $46 \mathrm{~mm}$. & $50 \mathrm{~mm}$. & $5+\mathrm{mm}$. \\
\hline $36 \mathrm{~mm}$. & $31 \mathrm{~mm}$. & $35 \mathrm{~mm}$. \\
\hline $55 \mathrm{~mm}$. & $45 \mathrm{~mm}$. & $50 \mathrm{~mm}$. \\
\hline $46 \mathrm{~mm}$. & $45 \mathrm{~mm}$. & $47 \mathrm{~mm}$. \\
\hline $65 \mathrm{~mm}$. & $5^{\circ} \mathrm{mm}$. & $51 \mathrm{~mm}$. \\
\hline $59 \mathrm{~mm}$. & $52 \mathrm{~mm}$. & $54 \mathrm{~mm}$. \\
\hline $73 \mathrm{~mm}$. & $56 \mathrm{~mm}$. & $66 \mathrm{~mm}$. \\
\hline $73 \mathrm{~mm}$. & $63 \mathrm{~mm}$. & $66 \mathrm{~mm}$. \\
\hline $69 \mathrm{~mm}$. & $67 \mathrm{~mm}$ & 7t $\mathrm{mm}$. \\
\hline If $\mathrm{mm}$. & $66 \mathrm{~mm}$. & \\
\hline
\end{tabular}

Four cervical vertebrae were preserved with the skull number 3207, of which only about a thircl of the atlats is represented, but fortunately we found a complete atlas isolated and of the same size. The measurements for the atlas are taken from this separate specimen. While my skull, especially the teeth, seems to have heen larger than the skull (iaudry described, the cervicals art a little smaller. I give the measurements of the cervicals which we found, comparing them with the figures given by Gaudry.

* Figures taken from illustrations. 


\begin{tabular}{|c|c|c|}
\hline & $\begin{array}{l}\text { SPECIMEN } \\
3344\end{array}$ & $\begin{array}{l}\text { GAUDRY'S } \\
\text { SPECIMENS }\end{array}$ \\
\hline $\begin{array}{l}\text { Atlas, antero-posterior length (without hypophysis) } \\
\text { Atlas, greatest width } \\
\text { Atlas, height }\end{array}$ & $\begin{array}{l}\mathrm{I} 20 \mathrm{~mm} \text {. } \\
304 \mathrm{~mm} \text {. } \\
129 \mathrm{~mm} \text {. }\end{array}$ & $\begin{array}{l}\mathrm{I} 40 \mathrm{~mm} \text {. } \\
365 \mathrm{~mm} \text {. } \\
\mathrm{I} 40 \mathrm{~mm} \text {. }\end{array}$ \\
\hline & $\begin{array}{c}\text { SPECIMEN } \\
3207\end{array}$ & \\
\hline $\begin{array}{l}\text { Axis, antero-posterior length } \\
\text { Axis, greatest width } \\
\text { Axis, width of odontoid process } \\
\text { Axis, length of odlontoid process }\end{array}$ & $\begin{array}{l}116 \mathrm{~mm} \text {. } \\
223 \mathrm{~mm} \text {. } \\
96 \mathrm{~mm} \text {. } \\
48 \mathrm{~mm} \text {. }\end{array}$ & $\begin{array}{r}124 \mathrm{~mm} . \\
248 \mathrm{~mm} . \\
88 \mathrm{~mm} . \\
44 \mathrm{~mm} .\end{array}$ \\
\hline $\begin{array}{l}\text { Cervical } 3 \text {, length of centrum antero-posterior } \\
\text { Cervical } 3 \text {, width of centrum } \\
\text { Cervical } 3 \text {, height of centrum } \\
\text { Cervical } 3 \text {, width of neural canal } \\
\text { Cervical } 3 \text {, height of neural canal }\end{array}$ & $\begin{array}{rl}47 & \mathrm{~mm} \\
125 \mathrm{~mm} \\
105 \mathrm{~mm} \\
75 \mathrm{~mm} \text {. } \\
22 \mathrm{~mm} \text {. }\end{array}$ & $\begin{array}{l}45 \mathrm{~mm} \text {. } \\
\mathrm{I} 45 \mathrm{~mm} \text {. } \\
\mathrm{I} 00 \mathrm{~mm} \text {. }\end{array}$ \\
\hline $\begin{array}{l}\text { Cervical } 4 \text {, length of centrum antero-posterior } \\
\text { Cervical } 4 \text {, width of centrum } \\
\text { Cervical } 4 \text {, height of centrum }\end{array}$ & $\begin{array}{l}45 \mathrm{~mm} \text {. } \\
\text { I } 32 \mathrm{~mm} \text {. } \\
\text { I05 } \mathrm{mm} \text {. }\end{array}$ & \\
\hline
\end{tabular}

The humerus is flattened from front to back in a striking manner, so that, seen from the side, it looks most slender; while in reality it is a very broad bone, nearly straight, and with marked rugosities for the attachment of the muscles. We found but one specimen of the humerus, an isolated bone a little smatler than that descriled by Gaudry.

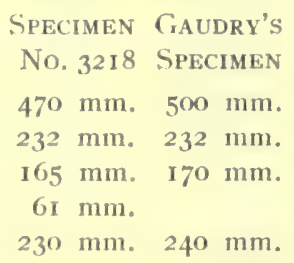

Humerus, total length

Humerus, width at proximalend

Humerus, width at middle of shaft

Humerus, antero-posterior diam. of shaft

Humerus, wilth across epicondyles

$230 \mathrm{~mm}$. $240 \mathrm{~mm}$.

We found neither the radius nor the ulna, but Gaudry figures both, giving the following measurements.

Radius, length

Radius, proximal diam.

Ulna, length (calculated)

Ijna, width of olecranon
$245 \mathrm{~mm}$.

$127 \mathrm{~mm}$.

$280 \mathrm{~mm}$.

$140 \mathrm{~mm}$. 


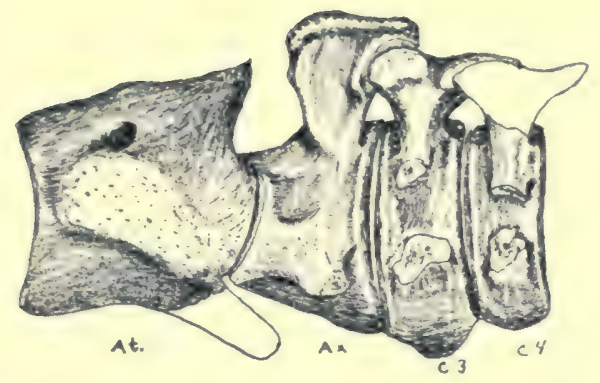

Fig. I15. At., atlas; $\boldsymbol{A} x$, axis; $\boldsymbol{C} .3$, third cervical; $C$.4. fourth cervical $-1 / 5$ natural size; apophysis of atlas is restored after Gaudry and the neural arch of cervical 4 is restored from the opposite side.

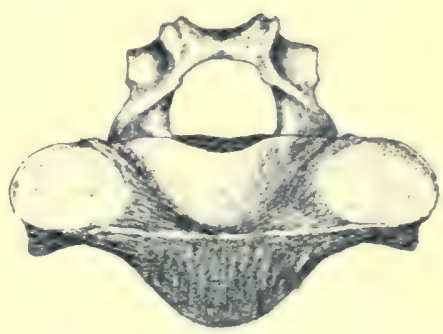

Fig. Ir6. Axis- $1 / 5$ natural size, front view.

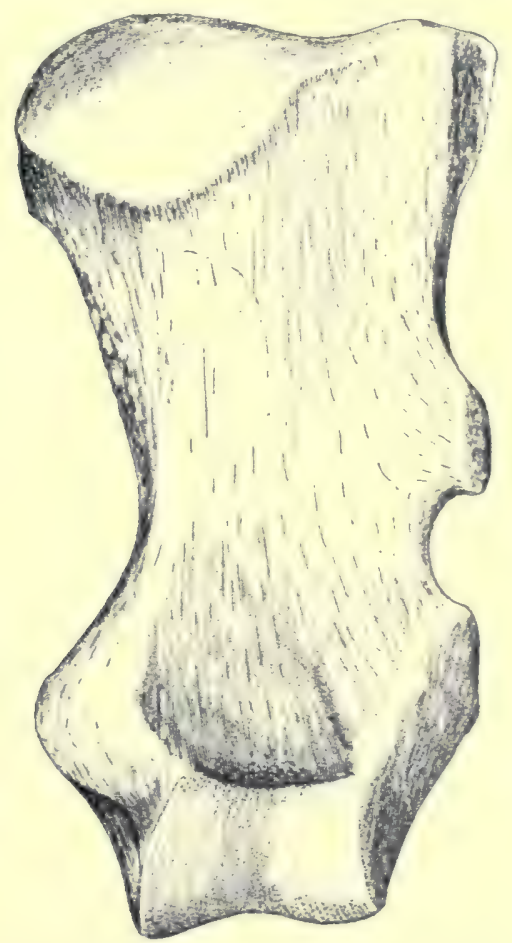

Fig. I17. Anterior face of the humerus $-1 / 5$ natural size. 
For the hind limb I give some of the figures which Gaudry gives accompanying his illustrations of the hind limb.

\section{Femur, length}

Femur, greatest proximal diameter

Femur, distal diameter

Tibia, length

Tibia, greatest proximal diameter

Tibia, greatest distal diameter

Astragulus, antero-posterior diam.

Astragulus, transverse diam.

Astragulus, height
$630 \mathrm{~mm}$.
$240 \mathrm{~mm}$.
$170 \mathrm{~mm}$.
$370 \mathrm{~mm}$.
I64 $\mathrm{mm}$.
I $4 \mathrm{~mm}$.
$123 \mathrm{~mm}$.
I $4 \mathrm{~mm}$.
$65 \mathrm{~mm}$. 


\section{CHAPTER XIII}

\section{RODENTIA}

While all of small size, numerically the rodents make about a third of our collection, the number of genera and species being, however, relatively small. All are hystricomorphs with the pattern on the crowns of the teeth relatively simple. While the incisors are typically rodent-like, permanently growing teeth, the molars are all rooted, some being entirely brachydont, others beginning to show hypsodont features.

So far as yet known, the rodents make their first appearance in South America, in this I eseado formation. Were they, as Ameghino thought, developed there from such a form as Propolymastodon or Promysops of the Casamayor formation? Or did they migrate into Patagonia from some other section? For the former proposition to be convincing to me, it would repuire more complete material of the forms suggested than now exists.* Other groups of hystricomorphs occur in the Theridomyidae of the European Oligocente, and from the Oligocente of the Fay um. $\dagger$ Either the old world forms are descended from the South American forms, or vice-versa. The two Ifrican lower jaws are very much like those of Cephalomy's, and my feeling is that the Patagonian forms are derived from some immigrant reaching that section before I esearlo times.

The Ieseado genera are not widely different from each other, but it is evident that they are the representatives of at least two families, and my expectation is that other families will be found eventually to be already represented.

* I have a lower jaw of Propolymasiodon which, though not complete in front, gives me no suggestion that the incisor was rodent-like, and I am inclined to think that the incisor associated with the type of $P$. carlo-zilelli is a mistake.

†Osborn, Bul. Amer. Mus. Nat. Hist., Vol. 24, p. 265. 
Our material does not permit the discussion of the skeleton or even of the skull as a whole, for the specimens occur only as isolated jaws, palates, or even as isolated teeth. In a few cases, the upper and lower dentitions are associated, but in no case was skeleton material clearly associated with the teeth. The remains look very much like such as are often found today in the western United States under a hawk's nest or below the roosting place of owls. I think most of our specimens passed, before burial, through the stomach of birds or carnivors.

Ameghino puts most of the forms in the family Cephalomidue, which he considers ancestral to Hystricomorpha in general. I feel, however, that it is better to assign the I Deseado genera to the families which have persisted until recent times, as Scott and Ameghino, in another place, have done. There are six living families, four of which Scott found already represented in the Santa ('ruz. 'Two of these clearly may be continued back into the Deseado, the Erethizontidae, and the Chinchillidae, nothing as yet having been found to represent the Santa (ruz families Cavidae and Octodontidae.

\section{Chinchillidae}

In the Deseado, this family is represented by the genera Cephalomys, Scotamys, and possibly Litodontomys. Cephalomys is very abundant and seems to be ancestral to Perimys of the Santa Cruz; Scotamys is relatively rare but seems to be ancestral to Scotaeumys; while Litodontomys is also rare and as far as I can see without a successor.

Cephalomys Ameghino

Cephalomys Amegh., 1897, Bol. Inst. Geog. Argen., t. I 8, p. 494.

This is the common genus of the Deseado, over threefourths of the specimens of rodents found belonging to one of its three species. Its dental characters mark it 
clearly. All the premolars and molars are rooted, though the crown is incipiently hypsodont, as much so as in any rodent of this period. The incisors are moderately large with the anterior face slightly convex, and the anteroposterior diameter comparing with the transverse diameter as 3 does to 2 . The interval between the incisor and premolar 4 is moderate, indicating a short snout.

Each lower molar consists of two transverse laminae separated from each other by an internal and an external infolding, both of which approach the median line but do not meet, a narrow, longitudinal bar separating the folds and connecting the anterior and posterior laminae. On the inner side, the posterior lamina has a furrow extending to the middle of the tooth, but only sinking into the crown about a fourth of its height, so that, with wear, it appears first as a bay, later as a pit, and finally disappears. In general it will be found only on molar 3 , and may be wanting there on old individuals. On an unworn tooth, there occurs, on the inner side of the anterior lamina, a rudimentary pit corresponding to the one on the posterior lamina, but of much less depth, so that it is only occasionally seen, and that only on a very slightly worn tooth. The premolar differs from the foregoing in having a small median column on the anterior face of the anterior lamina.

In three cases we found the deciduous fourth premolar (see fig. II9A), a complicated tooth, consisting primarily of three laminae in which furrows have developed until there are four folds or furrows on the internal side, separating five crests; while on the external side there are three furrows and four crests. Ameghino's figure of this tooth in $C$. prosus has four laminae running clear across the tooth. I think the difference is due to his having an unworn deciduous premolar whereas mine are all worn considerably.

At first glance, the upper teeth appear strikingly different, resembling those of Perimy's to which genus they are 
probably ancestral. Each molar consists of two laminae, separated by a deep internal fold which extends almost to the external margin. On little worn teeth each lamina shows, on the external side, a shallow furrow extending to about the midclle of the tooth, but these furrows early become pits and then disappear with further wear, being preserved on not over a fourth of our specimens. The fourth upper premolar consists of two laminae, but in this case, the separating fold is on the external side and extends nearly to the internal margin, so that this tooth appears to be reversed in its position in the jaw. As in the molars, there is, on the external side of either lamina, a furrow, the one in the anterior lamina shallow and seldom seen, that in the posterior lamina deep and present in all but the most worn teeth.

While the upper and lower molars appear so different they may be readily derived from such a tooth as the lower molar, as both have the two laminae and separating furrows in common. In the upper molars, however, the internal fold is prolonged until the external fold is merely indicated or lacking. On upper premolar 4 , on the contrary, it is the external fold which is prolonged. The furrows in the external portions of the laminae of the upper molars correspond to those on the internal portions of the same laminae of the lower teeth, reversed, as is typical of all teeth.

Ameghino distinguished three species of Cephalomys, which are based primarily on size, the other characters which he gave being inconstant. We found these three and no others.

UPPER PM. 4 LOWER PM. 4

TO M. 3 TO M. 3

C. arcidens

C. plexus

I3-14 mm. I4-I5 mm.

C. prosus

$9.5 \mathrm{~mm}$. $10.5 \mathrm{~mm}$.

$8.5 \mathrm{~mm}$. $\quad 9.5 \mathrm{~mm}$. 


\section{Cephalomys arcidens Ameghino}

C. arcidens Amegh., 1897, Bol. Inst. Geog. Argen., t. 18, P. 494.

This, the type species, is hy far the commonest of the rodents, in fact of all the speries in the I. reado, and we found forty-seven specimens on the Chico del Chubut River, west of Puerto Visser. In the species there is considerable variation in size for

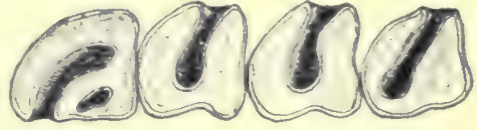

Fig. 178 , Right upper premolar, molar series $\times 4 / 1$. a rodent, but as there are intermediate sperimens all the way between the extremes, and as the variation is mostly
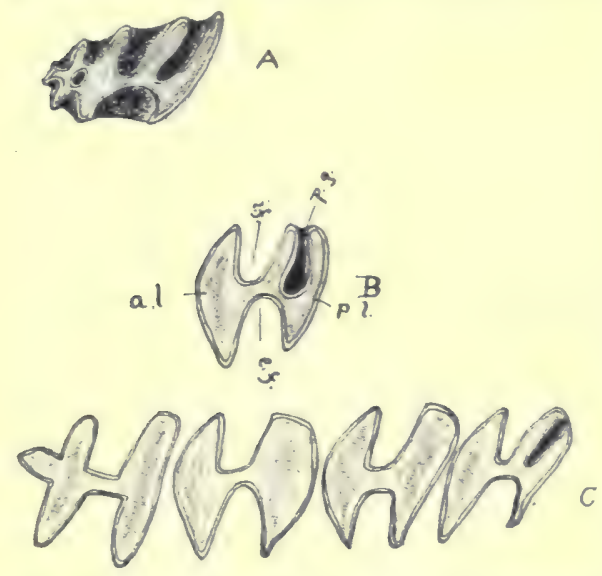

Fig. I 10. Left lower premolar, molar series; $A$, decoditous premolar 4 ; 13 , a little worn mola 1 ; $($, weries ahunt half worn down; a.l. anterior lamins; p.l., posterior lamina; i.f., internal fold; e.f., external fold; f.s., fur-

row in posterior lamina; $\times 4 / \mathrm{I}$ variation. The fol-
lowing measurements give the range of size on the upper

variation. The fol-
lowing measurements give the range of size on the upper jaws:

$\begin{array}{ccc}\text { SPECIMEN } & \text { SPECIMEN } & \text { AMEGiHINo's } \\ \text { 3IO9 } & 3099 & \text { TYPE } \\ \text { A SMALL } & \text { A LARGE } & \\ \text { INDIVIDUAL } & \text { INDIVIDTAL } & \\ 12.5 \mathrm{~mm} . & 13.5 \mathrm{~mm} . & 13.5 \mathrm{~mm} . \\ 3.5 \mathrm{~mm} . & 4.5 \mathrm{~mm} . & \\ 3 \mathrm{~mm} . & 3 \mathrm{~mm} . & \\ 2.75 \mathrm{~mm} . & 3 \mathrm{~mm} .\end{array}$

lipper premolar 4 to $\mathrm{m} \cdot 3$ I pper premolar 4, length Fach molar, length Each molar, width in the size of the fourth premolar, it does not seem proper to separate the material into more than one species.

In general, the form has relatively plump teeth, relatively heavier and thicker than in the other species. Usually the fourth premolar is but little larger than the molars, but, in this character, there is considerable variation. The fol- 
The lower jaw is low, heavy and rather short, the posterior part of the ramus being very thin, while the portion carrying the teeth is thick and heavy. A strong ridge extends along the inner side from just behind molar 3 to the hase of the symphysis. As in the upper dentition, there are smaller and larger forms.

$\begin{array}{ccc}\text { SPECIMEN } & \text { SPECIMEN } & \text { AMEghiNo's } \\ 3089 & 3058 & \text { TYPE } \\ \text { A SMALL } & \text { A LARGE } & \\ \text { INDIVIDUAL } & \text { INDIVIDUAL } & \end{array}$

Lower premolar 4 to $\mathrm{m} .3$

Lower incisor I to $\mathrm{pm} .4$

Height of mandible under pm. 4

Length of deciduous pm. 4
I $4 \mathrm{~mm}$. $15 \mathrm{~mm}$. $14.5 \mathrm{~mm}$.

$7 \mathrm{~mm} . \quad 9 \mathrm{~mm}$. $\quad 7.8 \mathrm{~mm}$.

$7 \mathrm{~mm}$. $8 \mathrm{~mm}$. $7 \mathrm{~mm}$.

$5.5 \mathrm{~mm}$.

\section{Cephalomys plexus Ameghino}

C. plexus Amegh., 1897, Bol Inst. Geog. Argen., t. I8, p. 494.

In general, this species is similar to the foregoing, but

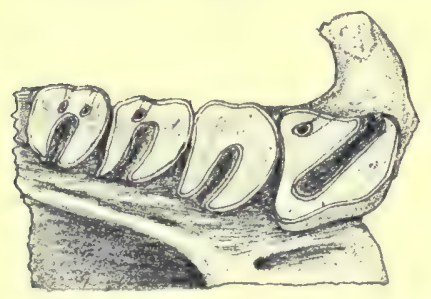

Fig. r20. Right palalate showing premolar, molar series; external furrows appear as pits on molars 2 and $3, x_{4} / 1$. is smaller in size and slenderer in proportions. Both the upper and lower fourth premolar tend to be considerably larger than the molars. The species was not nearly as abundant as $C$. arcidens, occurring but sixteen times in our collection.

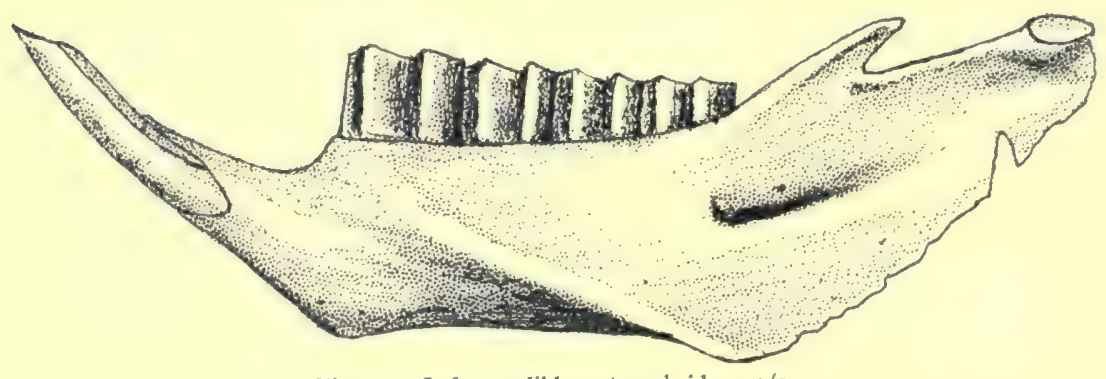

Fig. I2I. Left mandible, external side, $x_{4} /$ I. 
Measuremexts

l'pper dentition, pm. + to $\mathrm{m} \cdot 3$

I'pper dentition, pm. 4 , length

Upper dentition, each molar width
I'pper dentition, each molar length

\begin{tabular}{|c|c|}
\hline SPECIMEN & AMEGHINO'S \\
\hline 309 I & TYPE \\
\hline 9. $\mathrm{mm}$. & $9.5 \mathrm{~mm}$. \\
\hline $\begin{array}{l}2.75 \mathrm{~mm} \text {. } \\
2.1 \mathrm{~mm} \text {. }\end{array}$ & \\
\hline $2.25 \mathrm{~mm}$. & \\
\hline
\end{tabular}

The lower jaw is slenter, the incisor heing relatively both smaller and slenderer than in $C$. arcidens; the hack part of the ramus light and thin, the coronoid process being a tiny spur, and the articular condyle of small size, and on a level with the teeth.

\section{Measurements}

$\begin{array}{cc}\text { SPECIMEN } & \text { AMEghiNo's } \\ 3005 & \text { TYPE }\end{array}$

Lower dentition, pm. 4 to m. 3

Lower dentition, in. I to pm. 4

Lower dentition, pm. 4, length

Lower dentition, each molar, length

Lower dentition, each molar, wirlth

Height of mandible under pm. 4

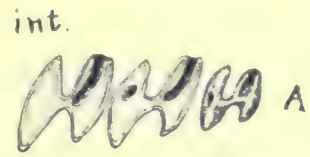

m. 23

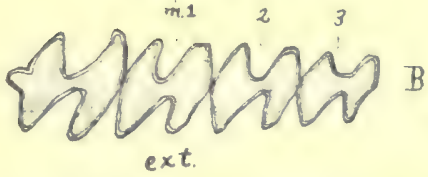

Fig. 122. C. plexus, left lower premolar, molar series; $A$, of young individual; $B$, of old individual; int., internal side; $e x t$. external side, $x_{4}$ I.

in $\mathrm{mm}$. I0.5 $\mathrm{mm}$.

$6 \mathrm{~mm}$. $6.5 \mathrm{~mm}$.

$3.5 \mathrm{mim}$.

$2.5 \mathrm{~mm}$.

$2 \mathrm{~mm}$.

$5 \mathrm{~mm}$. $+8 \mathrm{~mm}$.

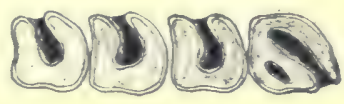

Fig. 123. C. prosus, left upper premolar, molar series, $x 4 / \mathfrak{s}$.
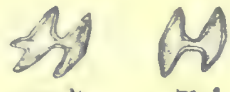

Fig. 124. C. prosus, premolar 4 and molar $2, x_{4} / \mathrm{r}$.

\section{Cephalomys prosus Ameghino}

C. prosus Amegh., 1902, Bol. Acad. Nac. Cienc. Cordoba, t. 17, p. 37.

This is the tiniest species of the genus, and least frequently found, probably because on account of the small size it was more frequently destroyed before burial, and also because it is hard to find such tiny specimens; so that 
the sixteen which we found would hardly represent the real proportion of the species in the fauna.

The jaws are not only small, lut also slender and delicately built, with the premolar about the same size or slightly larger than the molars. The drawings represent the proportions accurately so I will give but a few measurements.

Upper premolar 4 to molar 3

SPECIMEN

Lower premolar \& to molar 3 3009

$8.5 \mathrm{~mm}$.

Ameghino's TYPE

$9.5 \mathrm{~mm}$.

Scotamys gen. nov.

A lower jaw, with premolar 4 and molars I and 2, from the I eseado berds on the (hico del (hubut River, west of Puerto Visser, indicates a genus of hystricomorph rodents not previously reported. The lower molars suggest those of Perimys, but premolar 4 is similar to that of Scotaeumys from the Santa Cruz. Scotamys differs, however, from Scotucumys, in that its molars do not have the third lobe found in the Santa Cruz genus. I have, therefore, made a new genus which appears to be ancestral to Scotaeumys.

\section{Scotamys antiquus sp. nov.}

This, the type species of the above genus, is based on specimen 3063 , a lower jaw with the incisor, premolar 4

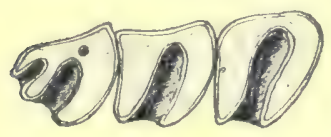

Fig. 125. Lower premolar 4 - molar $2, \mathrm{x}_{4}$. I. and the first two molars. The incisor is fairly large and heavy, the anterior face slightly convex, and the anterioposterior diameter greater than the transverse diameter. Premolar 4 has a deep external fold, dividing the crown into an anterior and posterior lamina, the former being then subdivided by another external fold, making the tooth three-lobed. Just internal to the median fold is a tiny pit, apparently the last vestige of an internal fold. Each molar consists 
of two laminae separated by a deep external fold, around the inner end of which the laminat are connected by a narrow bar. In the present condition of wear there is no indication of secondary furrows. The premolar is smaller than the molars.

\section{Measurements Specimen 3063}

Lower dentition, in. 1 to pm. 4 Lower dentition, premolar 4 length

Lower dentition, molar I length Lower dentition, molar 2, length Height of mandible under pm. 4

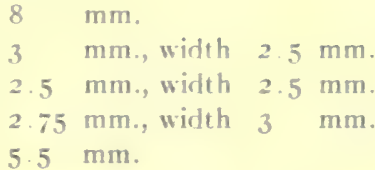

$\mathrm{mm}$

mm., width $2.5 \mathrm{~mm}$

$2.5 \mathrm{~mm}$., width $2.5 \mathrm{~mm}$.

$5.5 \mathrm{~mm}$

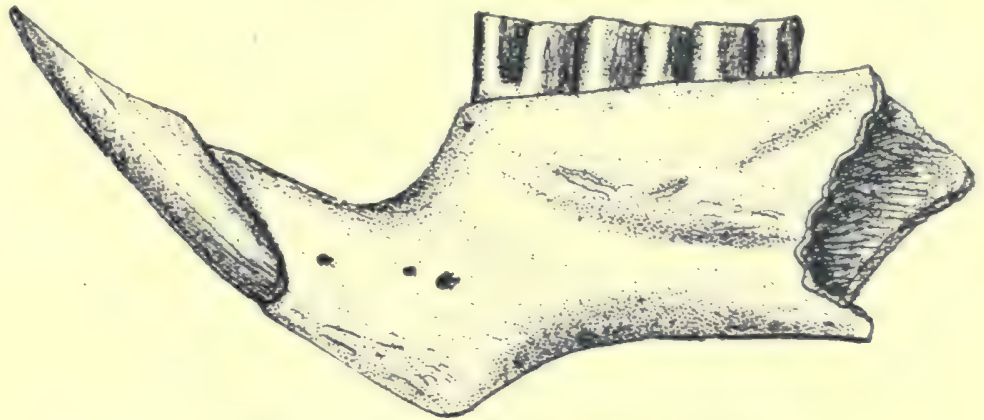

Fig. 126. Left mandible external side, $x+/ 1$.

\section{Litodontomys gen. nov.}

One set of lower teeth found by the Amherst party shows a simplicity of pattern found in no other senus of South America; and this is, therefore, named Litodontomy's. The teeth are brachydont, the premolar and the molars each being divided into two laminae hy an external and an internal fold, the distinctive generic feature being in that this fold is narrowest at the margin of the touth and expands internally. In connection with the expanded folds, the ends of the laminae are curved toward each other, so that in a worn specimen they would meet on the margins of the tooth, and leave the folds to appear as pits. No indication of a furrow is evident on either lamina. 


\section{Litodontomys chubutensis sp. nov.}

The type is number 3086 of the Amherst collection, from the Deseado beds on the ('hico del Chubut River, west

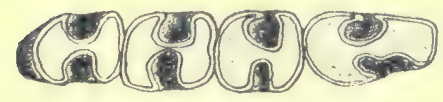

Figr. 127. Right lower premolar 4-molat $3, x_{4}: 1$. of Puerto Visser, and consists of the lower premolar-molar series.

Premolar 4 is elongated, the anterior lamina being considerably longer than it is wide, whereas the laminae of the other teeth are wider than they are long.

The following measurements with the figure give the specific details.

Lower dentition, premolar 4 , to molar 3

10. $5 \mathrm{~mm}$.

Lower dentition, premolar 4 , length

I.ower dentition, molar I, length

I.ower dentition, molar 2, length

$3.5 \mathrm{~mm}$.

I.ower dentition, molar 3 , length

2. $\mathrm{mm}$.

$2.5 \mathrm{~mm}$.

$2.5 \mathrm{~mm}$.

Lower dentition, width of molars

2. $\mathrm{mm}$.

\section{ERETHIZONTIDAE}

\section{Asteromys Ameghino}

Asteromys Amegh., 1897, Bol. Inst. Geog. Argen., t. I 8, p. 495.

The genus contains small forms, with brachydont teeth. The upper molars consist of two laminae, separated by an internal and an external fold, and each lamina having, on the internal half, a deep furrow, which is but little shallower than the median fold; so that the outer side shows three furrows, folds, or pits, more or less completely separating four lobes; while on the inner side of the tooth there are but two lobes. On the lower teeth the external median fold is deep, while the internal median fold is shallower, usually appearing as a pit. Both the anterior and posterior laminae are subdivided by wide internal furrows which extend to the median line.

These characters associate the genus with Acaremys of the Santa (ruz, from which genus it is not easy to separate 
Asteromys; but as we know only the teeth from the I leseade beds, it is probable that, when the skull is found, larger differences will be recognized. Asteromys appears to be the direct ancestor to Acaremys.

The species are all tiny, the following three being distinguished by Ameghino.

LENGTH OF LOWER

Molar Series

A. punctus (Bol. Inst. Geog. Argen., 1897, t. 18, D. 495)

$12 \mathrm{~mm}$.

A. annectens (Bol. Acad. Nac. Cienc. Cordoha, 1902, t. 17, p. 37) II mm.

A. prospicuus (Bol. Inst. Geog. Argen., I897, t. 18, p. 495) each molar 1.6 to $1.8 \mathrm{~mm}$.

Of these three we found only the last.

\section{Asteromys prospicuus Ameghino}

A. prospicuus Amegh. loc. cit. above.

The species is rare, only three specimens turning up in our collections. The upper molars are as described in

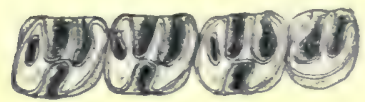

Fig. 128. Right upper premolar 4molar $3, x 4 / 1$.

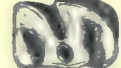

Fig. 129. Left lower molar $2, x 4 / x$

the generic discussion, hut premolar $t$ is simpler than the molars, the posterior lamina being small and without any sort of furrow. In the upper molars the anterior lamina is larger than the posterior, and the anterior furrow wider than the posterior. The following measurements, with the figures, indicate the character of the species.

Upper dentition, premolar 4 to molar 3

$$
\begin{array}{lll}
8 & 75 & \mathrm{~mm} \\
2 . & \mathrm{mm} \\
2 & 3 & \mathrm{~mm} . \\
2 . & \mathrm{mm} . \\
2 . & 75 \mathrm{~mm} . \\
\text { 1. } 75 \mathrm{~mm} .
\end{array}
$$$$
\text { I'pper dentition, premolar } 4 \text {, length }
$$$$
\text { Upper dentition, each molar, length }
$$$$
\text { Upper dentition, each molar, width }
$$$$
\text { Lower dentition, molar 2, length }
$$$$
\text { Lower dentition, molar 2, width }
$$ 


\section{Eosteiromys Ameghino}

Eosteiromys Amegh., 1902, Bol. Acad. Nac. Cienc., Cordoba, t. 17, p. Iro.

The genus was rstathlished by Ameghino for forms similar to Steiromys of the Santa Cruz, but antedating that time. I confess I can see but little difference between Steiromys and Eosteiromys, but the latter is as yet known only from isolated tecth and as in general it would be expected that there should be a generic difference, we may let this genus stand representing rather a prophecy than the facts as yet known.

The upper teeth are brachyclont, the crown being on the same general plan as in the foregoing genus, $i$. $e$, it is divided into an anterior and posterior lamina by a deep (xternal meaian fold and by a shorter oblique internal median fold. The anterior lamina is subdivided by two external furrows, a lesser anterior and a larger posterior; white the posterior lamma is sublivided by a single external furrow; so that this tooth has four folds, furrows, or pits on the external side separating five lobes; while on the inner side there is but the one oblique fold separating two lobes.

\section{Eosteiromys medianus Ameghino}

? E. merlianus Amegh., 1902, Anal. Mus. Nac. Buenos Aires, ser. 3, t. 2, p. I29.

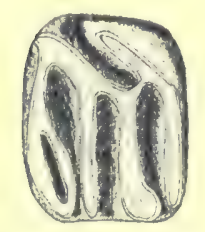

Fig. 130. Right upper molar, $2 \times 4 / 1$

The genus is based on a single, though cntircly characteristic, upper molar. We found just one tooth of the species, also an upper molar. It is described ahove, under the genus. The measurements are: Upper molar 2 , length $4 \mathrm{~mm}$., width $5 \mathrm{~mm}$. 


\section{CHAPTER XIV}

\section{Enentata}

THE scarcity of edentates in the Deseado beds is in striking contrast to their abundance in the Santa ('ruz formation. Whereas in this latter horizon over half of the finds are edentates, in the I decealo only eight per cent of the total collection belong to this group), and this is doubtless a larger proportion than these animals represented in the fauna; for the hunclreds of small plates in a carapace, when scattered greatly, increase the chance that some part of an individual will be found, and most of the eight per cent. of finds are single plates. Most of the plates found represent armadilloes, our collection containing but one plate of a glyptodont, and no gravigrades. Imeghino's collections present about the same relations, but in the repeated trips he found a few more traces of slyptodens and a very few gravigrades.

This scarcity of edentates can not be taken to mean that they were not developed, for they are a peculiarly South American group, and as they were developing somewhere into their great complexity; I take it to mean that the climatic conditions were unfavorable in this particular section.

As noted above, all previous finds have been isolated plates. We were fortunate enough to find one specimen consisting of a carapace with ten rows of movable plates in place, and parts of four rows of the pelvic buckler together with wer fifty isolated plates. I second specimen had some fifty associated plates which were mostly from the pelvic buckler.

\section{Dasypoda}

The representatives of this group are so poorly known in the Deseado beds that Ameghino has, in general, used 
the generic names of the Santa Cruz for their description, and, so far as known, they are little differentiated from those genera. There is as yet no material which shows the association of skeletal parts with the carapaces. Therefore, in this paper, comparisons are made wholly on the carapace, with the expectation that the skeleton, when found, will correspond.

The Deseade species are but little less specialized than the Santa ('ruz, the carapace consisting of movable overlapping bands of plates both in the anterior and body portions, while over the pelvic region the plates are fixed, do not overlap, and form a pelvic buckler.

Ameghino has described a considerable number of genera based on isolated plates, to which I refer later. The chief genera which occur in these beds are also found in the Santa ('ruz, and the distinguishing features are as follows:

\begin{tabular}{|c|c|c|c|c|}
\hline & Cephalic Shield | & | Movable Plates & Pelvic Buckler & ORNAMENTATION \\
\hline Proeutatus & $\begin{array}{l}\text { Plates thin, coarsely } \\
\text { pitted }\end{array}$ & $\begin{array}{l}\text { Plates thick, } \frac{1}{3} \text { over } \\
\text { lapped }\end{array}$ & $\begin{array}{l}8+\text { probably no } \\
\text { rows }\end{array}$ & "Flask" figure \\
\hline Prozaedius & $\begin{array}{l}\text { Plates thin, finely } \\
\text { pitted }\end{array}$ & $\mid \begin{array}{l}\text { I4 bands, thin, } \\
\text { overlapped }\end{array}$ & 8 rows & $\begin{array}{l}3 \text { long ridges, } \\
\text { median ridge nar- } \\
\text { row }\end{array}$ \\
\hline Stenotatus & $\begin{array}{l}\text { Plates thick, coarsely } \\
\text { pitted }\end{array}$ & $\begin{array}{l}\text { Plates thick and } \\
\text { wide }\end{array}$ & I I rows & $\begin{array}{l}3 \text { long ridges, all } \\
\text { subequal }\end{array}$ \\
\hline Proeuphractus & & I overlapped & No buckler & \\
\hline Peltephilus & $\begin{array}{l}19 \text { or } 21 \text { Plates } 2 \text { or } 4 \\
\text { horns }\end{array}$ & $\begin{array}{l}\text { Wide and thin } 2-4 \\
\text { wide yits }\end{array}$ & Buckler & Large shallow pits \\
\hline
\end{tabular}

\section{Proeutatus Ameghino}

Eutatus Amegh., in part, 1887, Bol. Mus. La Plata, t. 1, p. 25.

Proeutatus Amegh., 1891, Revista Argẻn. d. Hist. Nat., t. 1, p. 327.

Thoracotherium Mercetat, 189 I, Revista Mus. La Plata, t. 2, p. 42.

Eutatus Lydekker, in part, 1894, Anal. Mus. La Plata, t. 3, p. 62.

P'rocutatus Scott, I903-5, Reports Princeton Patagonian Exp., vol. 5, p. 40.

This is the most frequently occurring genus in the I) eseado, but is as yet represented only by isolated plates. 
The genus is distinguished ly thick relatively long and narrow, movalle plates. each overlapperl by about a third of its length. The plates of the pelvic buckler are shorter and thicker, the exponed surface of each being ornamented hy a figure compared hy. Ameshine to a flats isere fig. I.3I), which figure is more distinct on the rear, farling away toward the front. ()n the plates of the pelvic buckler this figure is more accentuated, and from it, on either side. radiate two furrows dividing the surface inte several it to 5) areas. The entire surface of each plate is irregularly punctate.

\section{Proeutatus lagenaformis Ameghino}

P. sp? Amegh., 1895, Bol. Inst. (ieng. Argen., 1. 15, 1. 660.

P. lagenaformis Amegh., 1897, Bol. Inst. (ieog. Argen., t. I8, p. 507.

On the Chico del Chubut River, west of Puerto Visser, we found nine specimens of this species, all fragmentary, though one consists of over fifty more or less broken plates, mostly from the pelvic buckler. This is the only species of the genus from the Deseado, and corresponds to the description above. A movable plate generally measures about 28

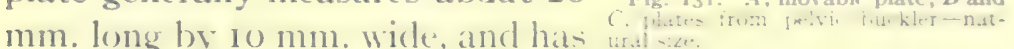
four laree piliferous pits on the posterior margin. I plate of the pelvic buckler varies greatly in size, hut is always thick and has two to eight piliferuss holes on the pusterior margin. A typical plate measures $20 \mathrm{~mm}$. long ly ro mm. wide,

\section{Prozaedius Ameghino}

Zaedius Amegh., in part, 1889, Act. Acad. Nac. Cordoba, t. 5, p. 86\%. Prozaedius Amegh., 1891, Revista Argen. Hist. Nat., t. I, p. 327. Dasypus Lydekker, in part, 1894, Anal. Mus. La Plata, t. 3, p. 55. Prozaedius Scott, 1903-5, Reports Princeton Patagonian Exp., vol. 5, p. 69.

Of this little genus, which is so strikingly like the living Zaedius, we found a carapace with ten ruws of movable 
plates in place, parts of four rows of fixed plates from the pelvic buckler, and some caudal vertebrac. The genus is distinguished by its thin plates, there being fourteen bands of movalble plates, and eight rows in the pelvic buckler. The movable plates are narrow, each overlapped about a fourth of its length, and have a faint ornamentation, with no piliferous pits except on the posterior margin. 'The fixed plates are similar, except that they are shorter, and have the ornamentation more accentuated, with radial grooves. Ameghino has described three species as follows:

P. impressus, sculpture little accentuated, post. piliferic pits rudimentary.

P. planus, sculpture more accentuated, post piliferic pits lacking.

P. tenuissimus, very small.

In my specimen, the two anterior rows of movable plates lack the maryinal piliferous pits, on the next two rows they are rudimentary (which is also true of the lateral plates even further back), while on the bulk of the movable plates and on those of the pelvic buckler there are two, three or four good-sized piliferous pits on the rear. I can therefore recognize but two species, $P$. impressus and $P$. tenuissimus.

\section{Prozaedius impressus Ameghino}

P. impressus Amegh., I 897, Bol. Inst. Geog. Argen., t. 18, p. 508.

P. planus Amegh., 1897, Bol. Inst. Geog. Argen., t. 18, p. 509.

Our specimen was found on the ('hico del ('hubut River, west of Puerto Visser, and preserves over two hundred plates, and eight caudal vertebrac. 'The anterior rows of plates of the carapace consist of thin plates overlapping about a fourth their length. Just behind the overlap, there is, on rach, a group of small punctations, and the exposed part of the surface is divided by two shallow furrows, making three more or less equal ridges which die out toward the rear, leaving the posterior part of the plate plain. These most anterior plates are bent to one side and have no piliferous pits on the rear margin. The plates of the third and fourth rows are not bent, and have the sculpture more distinct, the extreme lateral plates having no piliferous 

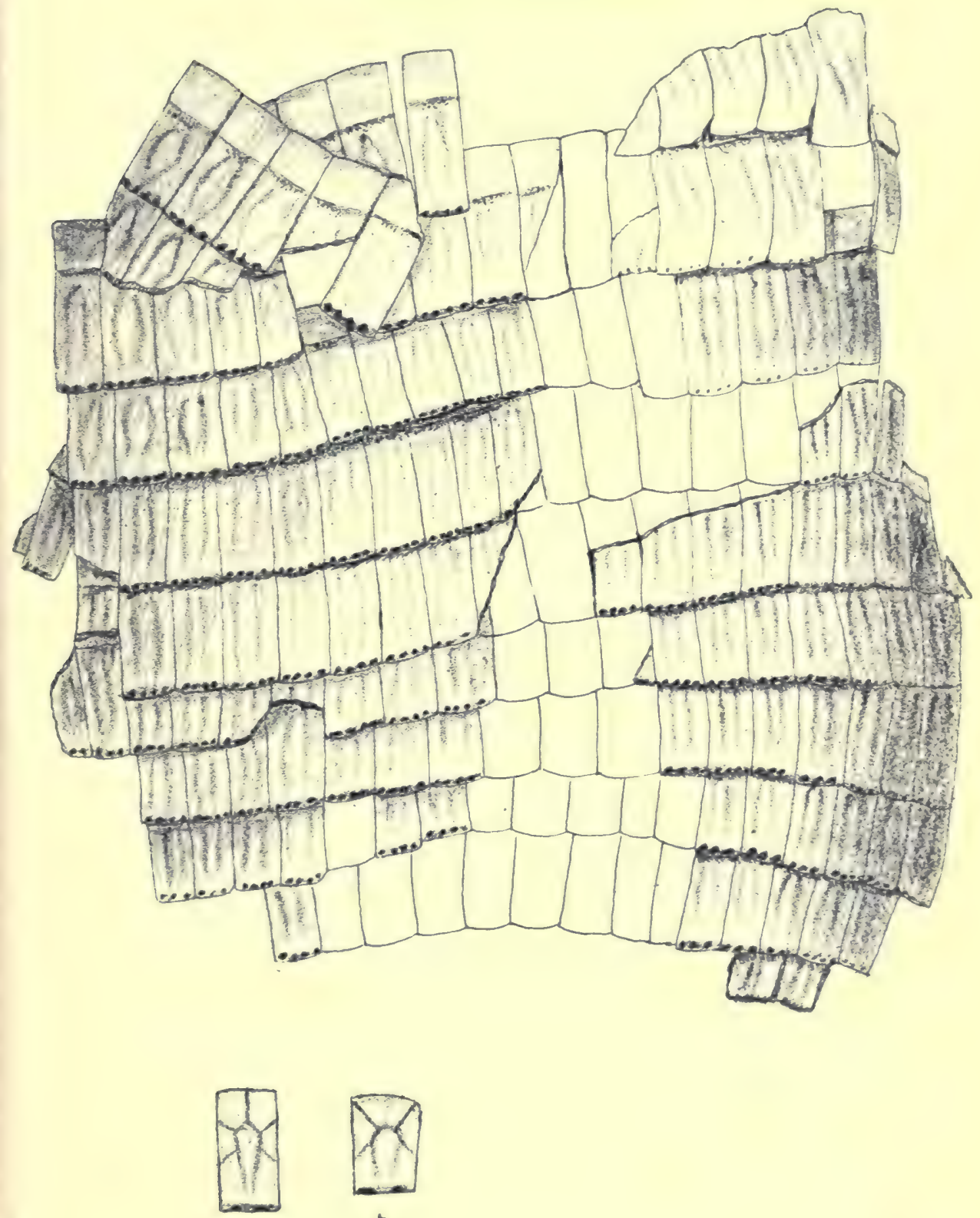

a

b

Fig. 132. Portion of carapace-natural size; unshaded plates are from cast; $a$ and $b$ plates from pelvic buckler. 
pits, the median lateral plates with rudimentary piliferous pits, and the dorsal ones with well marked posterior pits. In each succeding row toward the rear, the plates are more distinctly ornamented and have larger posterior marginal pits. I have no marginal plates.

The plates of the pelvic buckler do not overlap, are shorter, have a very distinct figure, and, in adclition to the longitudinal furrows, have a couple of radial furrows on either side, which divide the plate into four or five areas (see fig. I32 a and b).

The caudal vertebrae are short and thick, indicating a short tail. I found no plates which would indicate a caudal shield, which coincides with the experience among the Santa Cruz specimens. The figures are to scale and give most of the measurements.

There are ten rows of movable plates, probably two to three rows lacking. There are twenty + plates to a row.

A typical movable plate measures $17 \mathrm{~mm}$. long by $6 \mathrm{~mm}$. wide.

There were at least four rows in the pelvic buckler, probably eight as in the Santa Cruz.

A typical fixed plate measures $\mathrm{I} 0 \mathrm{~mm}$. long by $5 \mathrm{~mm}$. wide.

\section{Prozaedius tenuissimus Ameghino}

P. tenuissimus Amegh., 1902, Bol. Acad. Nac, Cienc, Cordoba, t. I7, p. 66.

This species is characterized by Ameghino on account of its small size. The movable plates have two furrows which converge toward the front, and between which is a median crest. In the furrows are two rows of perforations. A movable plate measures $9 \mathrm{~mm}$. long by $4 \mathrm{~mm}$. wide.

\section{Stenotatus Ameghino}

Euphractus Ameghino, in part, 1887, Bol. Mus. La Plata, t. 1, p.26 of separate. Dasypus Amegh., in part, I889, Act. Acad. Nac. Cienc. Cordoba, t. 5, p. 864.

Stenotatus Amegh., I891, Revista Argen. Hist. Nat., t. I, 1) 253.

Dasypus Lydekker, 1894, Anal. Mus. La Plata, t. 3, p. 55.

Prodasypus Amegh., I894, Bol. Acad. Nac, Cienc. Cordoba, t. I3, p. 172 of separate.

Stenotatus Scott, I903-5 Princeton Patagonian Exped., vol. 5, p. 80.

The genus is very like Prozuedius but differs in having thicker and wider movable plates, in having more rows of 
plates in the pelvic luckler (I ), and in details throughout the skeleton. We found no representatives of the genus, but Ameghino has descriled a species (no) figure), S. (Prodasypus) ornutus* based on isolated plates. 1 moxable plate measures is mm. Kong he 6-7 mm. wirle, while a fixed plate measures $9 \mathrm{~mm}$. long, by $6-7 \mathrm{~mm}$. wide.

\section{Proeuphractus Ameghino}

Proeuphractus Amegh., I886, Bol. Acad. Nac. Cienc. Cordoba, t. 9, p. 208.

This genus is seldom found, but is distinguished l,y. Ameghino by the absence of a pelvic huckler, all the plates of the crapace being movable. From the l teseado beds. Ameghino describes two species, $P$. setiger and $P$. lateis, buth based on isolated plates; the former distinguished hy having no piliferous perforation in the furrows surrounding the central figure, and with well-develeped pitson the posterior margin: while the latter has small piliferous perforations in the furrows and only rudimentary ones on the posterior margin. These features do not seem to me to distinguish species.

In addition to the foregoing, Ameghino has made a series of genera and species, $\dagger$. Irchuentutus, 1 mblytutus, Isutaetus, Sudypus, IIemiututus, -1 nutuetus, all based on isolated plates, and distinguished hy variations in the: central figure and the piliferous pits. I am unable to find a satisfactory hasis for distinguishing the generat or specie's, and feel that, until more complete material is known, it is impossible to say which are valid genera or species.

\section{Peltephilus Ameghino}

Peltephilus Amegh., 1887, Bol. Mus. La Plata, t. I, p. 25 of separate.

Cochlops Amegh., in part, 1889, Act. Acad. Nac. Cienc. Cordoba, t. 5, p. 792. Gephyranodon Amegh., I89I, Revista Argen., Hist. Nat., t. I, p. II9. ? Anatiosodon Amegh., 1891, Revista Argen. Hist. Nat., t. 1, p. 327.

Peltephilus Scott, ryo3-5, Princeton Patagonian Exped., vol. 5, 1. 88.

While rare, this genus is well known from the Santa Cruz, and is characterized by the curious development of

* Bol. Inst. Geog. Argen., t. 18, p. 508, 1897.

$\dagger$ Bol. Acad. Nac. Cienc. Cordoba, t. 17, p. 56-66, 1902, no figures. 
the head shield, which consists of nineteen or twenty-one definitely arranged head plates, the anterior ones being developed into horn-like projections. The plates of the carapace are wide, thin, and unique in each having two to four wide shallow pits on the exposed surface. We found the genus rare, only two isolated plates turning up. From the Deseado material Ameghino has made three species: $P$. protervus, of very large size; $P$. undulatus, of moderate size, with the median figure accentuated and ending in two pits and with piliferous depressions on the margin; and $P$. depressus, of the same size as the foregoing, with a faint central figure, often four pits on the exposed surface and no piliferous pits on the margin. We found but one species, one plate of which combines characters of both the last two as described, so that I feel that there should be but two species, $P$. protervus and $P$. undulatus.

\section{Peltephilus undulatus Ameghino}

P. undulatus Amegh., 1897, Bol. Inst. ( ieog. Argen., t. 18, p. 509.

P. depressus Amegh., 1897, Bol. Inst. Geog. Argen., t. 18, p. 5 ro.

One of the plates we found has the rough surface, obscure figure, two pits on the median part of the surface, and

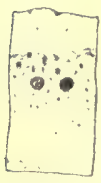

Fig. 133. Two movable plates-natural size. marginal piliferous pits, of which the first two features are characters of $P$. undulatus, the last is the feature of $P$. depressus, so I have combined the two species. A second plate does not have the marginal pits but is otherwise the same. I expect considerable variation in the pattern on plates from different regions of the carapace.

\section{Peltephilus protervus Ameghino}

P. protervus, Amegh., 1897, Bol. Inst. (ieng. Argen., t. 18, p. 509.

This species, of which we found no representative, is very large. The plates of the type have two pits on the 
anterior part of the expesed surfare and none on the margin. A movable plate measures fI $\mathrm{mm}$. long by $22 \mathrm{~mm}$. wide. One of the horn-like plates from the rephalie shiedd is $35 \mathrm{~mm}$. long. by $30 \mathrm{~mm}$. wille and has a height of $+4 \mathrm{~mm}$.

\section{GLYPTODONTIA}

This suborder is most sparingly represented. apparently on account of unfavorable habitat. Ameghino has described a few fragments of the carapares of these forms, making the genera. Pulucopeltis, and Glyplutelus, both pre-Santa Cruz genera.

\section{Palaeopeltis Ameghino}

Palaeopeltis Amegh., 1895, Bol. Inst. Geog. Argen., t. 15, p. 659.

The basis of this genus is a few plates of a glyptodonlike animal of consiclerahle sim, lut the plate's are without ornamentation. This form Ameghino considers intermediate between glyptodonts and armarlilloes. I feel that there is too little of the skeleton known to justify this conclusion, especially as glyptedonts of a considerably higher grade of specialization are contemporaries of this form.

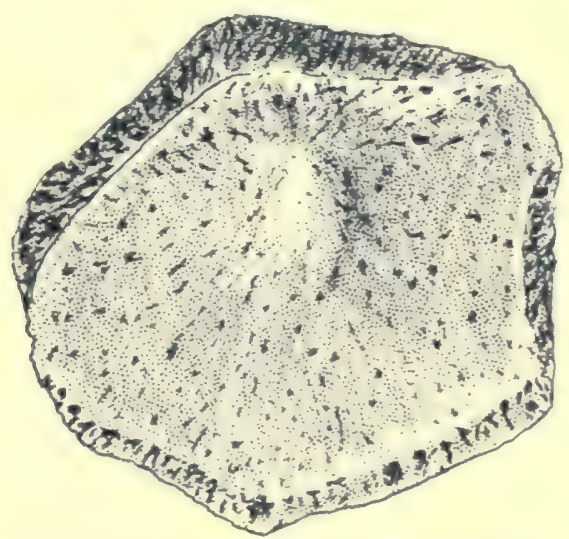

Fig. 234. P.inornatus: a single plate-natural size. 


\section{Palaeopeltis inornatus Ameghino}

P. inornatus Amegh., 1895, Bol. Inst. Geog. Argen., t. 15, p. 659.

P. inornatus Amegh., I 897, Bol. Inst. Geog. Argen., t. 18, p. 506.

The species is founded on four plates which are without ornamentation, and externally smooth except for numerous vascular perforations. They are of considerable size and entirely characteristic. The one such plate which we found is shown in fig. I34.

\section{Glyptatelus Ameghino}

Glyptatelus Amegh., 1897, Bol. Inst. Ceog. Argen., t. 18, p. 507.

The plates of the carapace are similar to those of Palaeohoplophorus, the ()-figure being, however, nearer the rear of each plate, and the number of radial furrows being smaller, usually six. We found no specimens of this interesting form. Ameghino has made two species, G. tatusinus and G. malaspinensis.

\section{Glyptatelus tatusinus Ameghino}

G. tatusinus, Amegh., 1897, Bol. Inst. Geog. Argen., t. 18, p. 507.

I reproduce Ameghino's figure of this species which shows all that is known of the form.

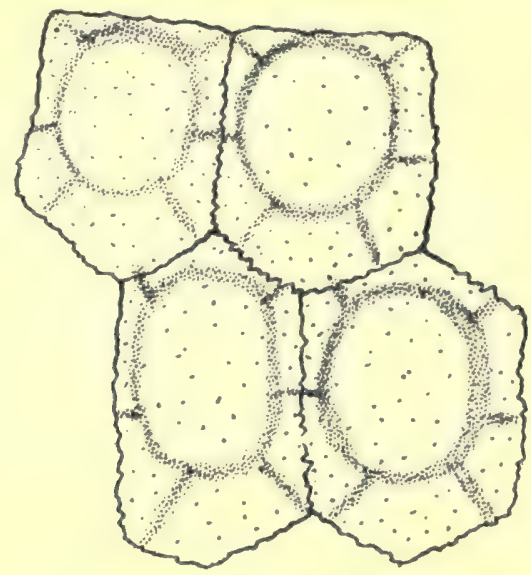

Fig. 135. Four plates-natural size, after Aneghino. 


\section{Glyptatelus malaspinensis Ameghino}

G. malaspinensis Amegh., 1902, Bol. Acad. Nac. Cienc., Cordoba, t. 17, p. 50. This species is described (no figure) as ahout the same size as the precerling. but with subordinate figures in the central ()-figure, and also outside of it. A dorsal plate measures $26 \mathrm{~mm}$. long by $20 \mathrm{~mm}$. wide.

\section{GRAVIGRADA}

Remains of this suborder are almost as rare as those of the glyptoxtonts, and apparently for the same reason, unfavorahle habitat. We found no remains of this group, hut Ameghino has described a skull and some teeth as belonging to this group) so, in order to present a complete view of the Deseade fauna, I give a digest of his descriptions.

\section{Hapalops antistis Ameghino}

H. antistis Amegh., I 897, Bol. Inst. Geog. Argen., t. 18, p. 505.

The species is hased on a skull, not figured, of which Ameghino says: the size is small, the molars are compressed from front to hack, and gives the following measurements:

Length of cranium from front of max. to occ. condyles

Length of four post. molars

I $40 \mathrm{~mm}$.

Distance from front of max. to back of last molar

$27 \mathrm{~mm}$.

$48 \mathrm{~mm}$.

\section{Octodontotherium Ameghino}

Octodontotherium Amegh., I 895, Bol. Inst. Geog. Argen., t. 15, p. 656.

The genus is based on isolated teeth, each a mass of dentine surrounded hy a thin layer of cement. The anterior tooth of the upper jaw is caniniform, the first molar croid in section, the last molar is bilobed. corresponding to Pseudolestodon. The first tooth of the lower jaw is also caniniform, but is two-faced as a result of wear. The intermediate upper and lower molars are rectangular prisms resembling those of Chlamdotherium. 


\section{Octodontotherium grandis Ameghino}

O. grandis Amegh., I 895, Bol. Inst. Geog. Argen., t. 15, p. 656 .

O. grandis Amegh., I 897, Bol. Inst. Geog. Argen., t. 18, p. 505.

In addition to the above, Ameghino simply gives the following measurements:

First upper tooth, ant.-post. diam. $20 \mathrm{~mm}$., trans, diam. $13 \mathrm{~mm}$., height $80 \mathrm{~mm}$. First lower tooth, ant.-post, diam. 2 I mm., trans. diam. $16 \mathrm{~mm}$., height $80 \mathrm{~mm}$. I.ast lower tooth, ant.-post. diam, $28 \mathrm{~mm}$., trans, diam, of ant lobe $18 \mathrm{~mm}$. Last lower tooth, trans. diam. of post. lobe $16 \mathrm{~mm}$., median diam. $7 \mathrm{~mm}$.
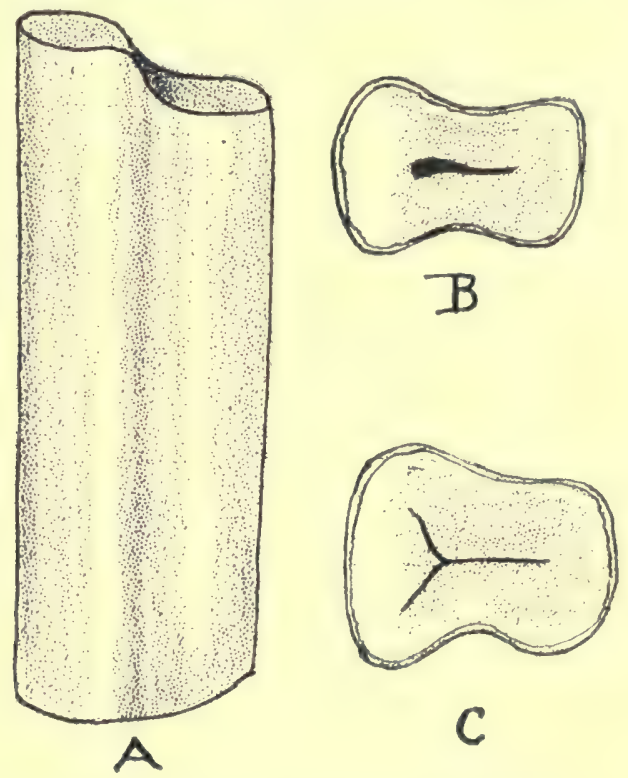

Fig. 136. $A$, lower molar, side view-natural size; $B$, lower molar, cross section-natural size; $C$, upper molar, cross section-natural size, after Ameghino.

\section{Octodontotherium crassidens Ameghino}

O. crassidens Amegh., I 897, Bol. Inst. Geog. Argen., t. 18, p. 505.

This second species is based on isolated teeth of larger size than the preceding, with measurements as follows:

I pper molar, ant.-post. diam. $26 \mathrm{~mm}$., trans. diam. $18 \mathrm{~mm}$.

Lower molar, ant.-post. diam., $26 \mathrm{~mm}$., trans. diam. of ant. lobe $21 \mathrm{~mm}$., trans. diam. of post. lobe $16 \mathrm{~mm}$. 


\section{Orphodon Ameghino}

Orphodon Amegh., 1895, Bol. Inst. Geog. Argen., t. 15, p. 658.

Orphodon Amegh., 1897, Bol. Inst. Geog. Argen., t. 18, p. 504.

The teeth of this type are a mass of dentine, each surrounded by a thin layer of cement, and each tocth subeylindrical in section, with the (rown worn to two apposed oblique planes. The genus resembles Ortotherium.

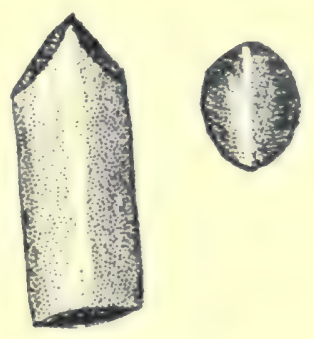

Fig. 137. Type-natural size, after
Ameghino.

\section{Orphodon hapaloides Ameghino}

O. hapaloides Amegh., I 895, Bol. Inst. Geog. Argen., t. I5, p. 658. O. hapaloides Amegh., 1897, Bol. Inst. Geog. Argen., t. 18, p. 505.

In addition to the above, Ameghino gives a figure, here reproduced, and the following measurements: Tooth, greatest diam. $12 \mathrm{~mm}$., lesser diam., Io $\mathrm{mm}$. 


\section{CHAPTER XV}

\section{Marsupialia}

IN OUR collection, the marsupials are represented, unfortunately, by but a few specimens; though this Deseado fauna included, as is shown by the fragmentary remains, a wide range of forms from Pilchenia, the size of a mouse, ui) to the bear-sized Proborhyena. 'The small forms were probably insectivorous, while the larger forms took the place of the carnivors, the absence of true Carnivora being one of the striking features of the fauna of South America during earlier Tertiary times.

The treatment of these forms has been as varierl as their sizes. Ameghino, with his idea that the ('asamayor and 1) escado heds were (retaceous in age, groups the larger forms as a suborder, Sparassodonta, and considers them ancestral to the Creodonta; while the small forms make up) his Sarcobora which he considered ancestral on one side to the rodents, on the other to the diprotodont marsupials. Sinclair, after showing the marked similarity of the Sparassodonta to the polyprotodont marsupials, especially the genus Thylacynus, abandons that term and puts them in the family Thylacynidae along with the Australian forms; the Microbiotheridae he finds similar to opossums and puts in the family Didelphidae; while the remaining small diprotodont forms he associates with Cacnolestes, and using Ameghino's families as subfamilies makes three divisions of the family, Palacothentinae, Garzoninae, and Abderitinae. Natthew finds the sparassodonts to be true marsupials, and without phylogenetic relationship with the creodonts. (iregory diagrams the sparassodonts as coming from generalized didelphids and derives them from the same line as the Australian polyprotodonts; while the small cacnoles- 
toids represent a line of descent from some still earlier generalized polyprotortonts and a separate stem from the Australian diprotodonts.

Sinclair has had the most complete material on which to work, and with his general grouping I have come to agree. This recognizes three divisions of South American Marsupials, the Didelphidae, representatives of which have not yet been found in the I)eseado, though occurring in both the earlier and later formations; the Cacnolestidac represented today by Caenolestes, the only survivor of the South American diprotodonts; and the Borhyenidae. (= Thylac ynidae of Sinclair this name having been used to indicate a much nearer relationship to the Australian Thylacynus than I feel is warranted), which includes a large range of medium to large sized animals ranging from the Casamayor formation throught the Santa Cruz beds.

The locality from which these marsupials emigrated to South America and the time of their arrival is not yet agreed upon, and can not be settled until much more complete material is discovered in the Casamayor formation. I feel, however, that the three groups were separate when they entered South America.

\section{Borhyaenidae}

Ameghino has grouped in this family a considerable number of genera of powerful, wolf-like carnivorous marsupials, characterized by a dental formula ${ }_{3}^{4-3} \frac{1}{1}+3$ * heavy heads, short limbs with usually five semidigitigrade toes. The genera are mostly distinguished by the relative development of the protocone on the upper molars and the

* There is a discussion as to the homologies of the premolars of marsupials and placental mammals, the one proposition being that marsupials have three premolars and four molars, the other that they have four premolars and three molars as in placentals. The evidence is not conclusive as to either proposition, but in this paper I have designated these teeth along the latter line of thought. 
talonid on the lower ones. Figure 1,38 gives a typical marsupial upper molar 2 and a lower molar 2 to show the sense in which these terms are used. The Santa Cruz genera are the best known and I therefore use them as a basis for comparison with the less known Deseado forms, of which we found but the one genus Pharsophorus at all abunclant. In addition to this, Ameghino has reported a gigantic form designated Proborhyaena. The following table inclicates the relationships of the best known genera.

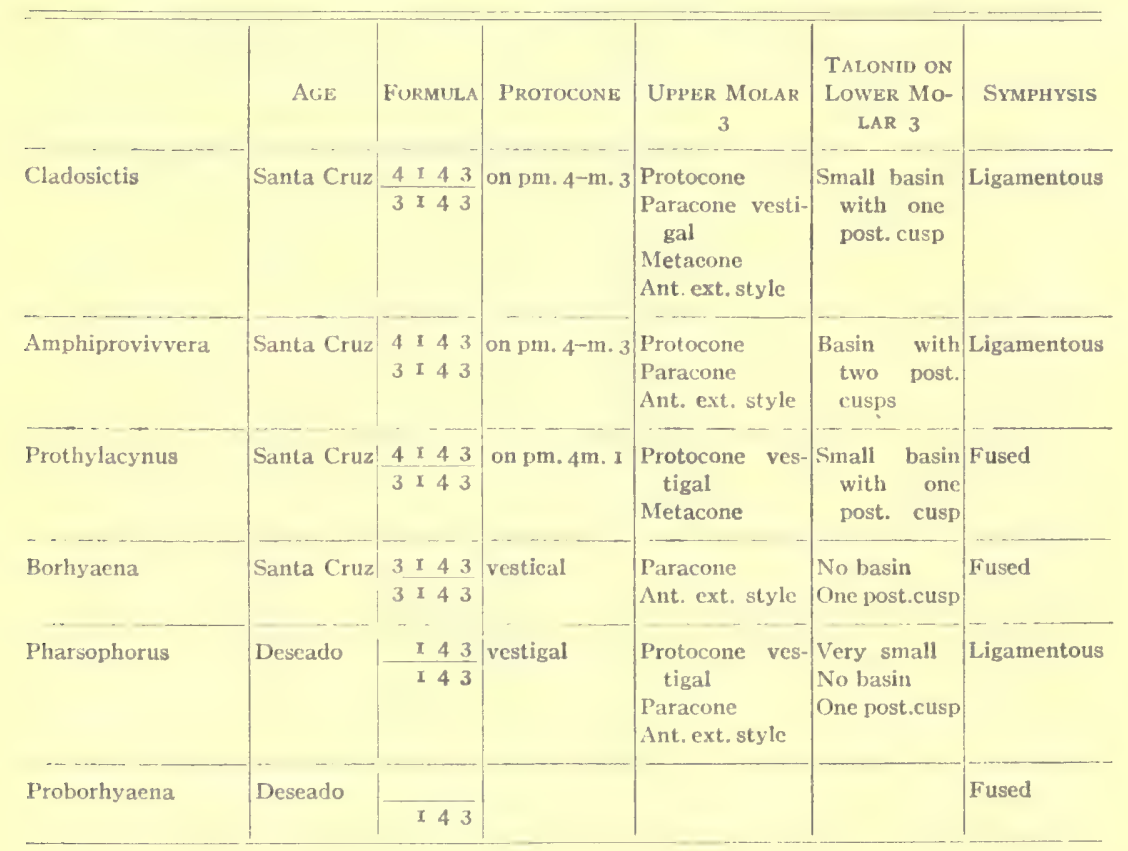

From the foregoing, it will appear that Pharsophorus approaches Borhyacna and Prothylacynus in the structure of its upper molars, being, however, nearer to the former, and the same is true of the structure of the talonid; but Pharsophorus differs markedly from both in retaining the metaconid as a small cusp on the side of the protoconid on all of the lower molars; also in the extremely small size 
of the talonid of the lower molars, which in Pharsophorus have no basin and consist of a single cusp); and, lastly, in the symphysis of the lower jaws being ligamentous, whereas in the two preceding sencera, it is fused. Pharsophorus is probably ancestral to Borhyente. In the case of Probor$h$ yenen, only a mandible, with the canine and premolars 3 and $t$ intact, has been found. The fourth premolar is more reduced than in other genera, but, until more teeth are known, its affinities can not lx at all chosely determined.
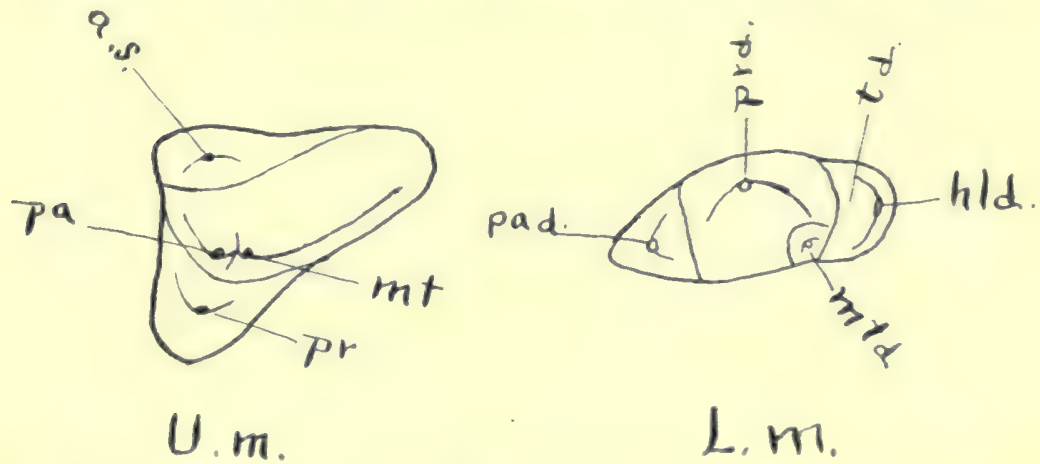

Fig. I38. Diagram of a generalized upper molar, $U$.m., and a lower molar. L.m., of Borhynidae; a.s, ant. style; hld., hypocunulid; mt., metacone; mid., metaconid; pu., paracone; pud., paraconid; pr., protocone; prd., protoconid; id., talonid.

\section{Pharsophorus Ameghino}

Pharspohorus Amegh., 1897, Bol. Inst. (ieog. Argen., t. 18, p. 502.

The genus was founded on a lower jaw with premolar 3 to molar 3 in position. Me found beside the above an upper jaw with premolar 3 , and molars 2 and 3 complete while premolar $t$ and molar I are more or less fragmentary; from which the following generic characters may be made out. The incisors are tiny; the canine very large, equal to that of Borhyenen; the upper and lower premolars progressively smaller from front to hack. Lpper premolar 3 is a simple two-routed tooth, the crown consisting of a single blunt central cusp). On the upper molars the protocone is not developed as a cusp, though the third inner root 
is present and carries a rounded shelf. The paracone is the chief cusp, and is developed as a high central pointed denticle. The metacone is not developed as a cusp, but is represented by a long slanting ridge to the rear, the apex of which has been fused to the paracone. The last upper molar is better developed than in most Santa Cruz genera, consisting of a high median cusp, the paracone; a small anterior cusp, the anterior external style; and a shelf-like posterior cusp, the protocone. Lower premolars $\mathbf{I}-3$ are simple two-rooted teeth, each carrying a single cusp on the crown. The fourth premolar carries a well marked paraconid in front, a large median protoconid on the rear of which is a tiny metaconulid; and a tiny talonid or heel which is without a basin and consists of a single tiny cusp. 'The molars are all of the same character as the last premolar. The lower jaws are united by a ligamentous symphysis.

Ameghino distinguished four species, $P$. lacerans, $P$. tenax, $P$. mitis, and $P$. temuis, in the order of their size. 'The last two are but little known but are quite certainly another genus.

\section{Pharsophorus lacerans Ameghino}

P. lacerans Amegh., 1897, Bol. Inst. Geog. Argen., t. 18, p. 503.

The species was founded on a lower jaw with the roots of the incisors, canine, and first two premolars, and with the remaining teeth intact. IVe did not find the species,

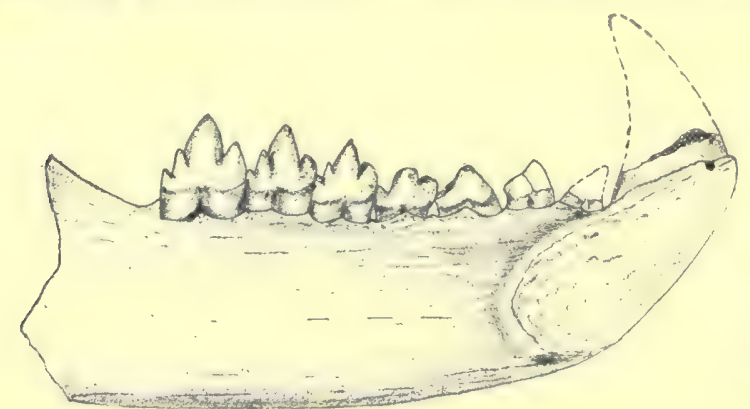

Fig. 139. Left mandible- - / $/ 2$ natural size, after Ameghino. 
so I have reproduced Ameghino's figure and give his measurements.

Lower dentition, length incisor 1 to molar 3

Lower dentition, length premolar 1 to molar 3

Lower dentition, height of mandible under pm. 4

$11 \mathrm{~mm}$.

$90 \mathrm{~mm}$.

$38 \mathrm{~mm}$.

Pharsophorus tenax Ameghino

P. tenax Amegh., 1897, Bol. Inst. Geog. Argen., t. 18, p. 504.

The species was based on a fourth premolar which was Io $\mathrm{mm}$. long as compared with $\mathrm{I} 3 \mathrm{~mm}$. in P. lacerans. $\mathrm{It}^{*}$ found on the Chico del Chubut, west of Puerto Visser, both an upper and lower jaw belonging to this species, which give us the knowledge of the upper dentition for the genus. The species is distinguished by the smaller size, relatively heavy jaws, and plump

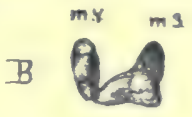
teeth, indicating a heavier built animal than $P$. lacerans. The following measurements distinguish the specie's.

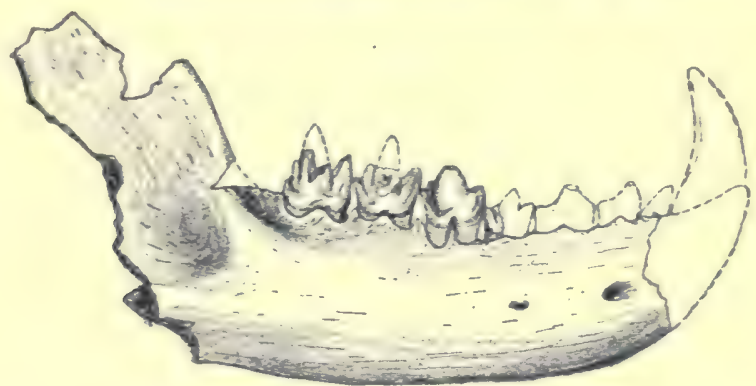

Fig. 1 q . Right mandible-I/2 natural size.

SPECIMEN 3192

Lpper dentition, length premolar I to molar 3

Upper dentition, premolar 3 , length

Upper dentition, molar 1 , length

Upper dentition, molar 2, length

Upper dentition, molar 3, length

$76 \mathrm{~mm}$.

10. $5 \mathrm{~mm}$., width $6 \mathrm{~mm}$.

II. $5 \mathrm{~mm}$., width $8.5 \mathrm{~mm}$.

$12 \mathrm{~mm}$., width $9 \mathrm{~mm}$. $.55 \mathrm{~mm}$., width $12 \mathrm{~mm}$. 
Lower dentition

SPECIMEN 3004

Distance from premolar I to molar 3

Molar I, length

I I mm., width

$76 \mathrm{~mm}$.

Molar 2, length

$13 \mathrm{~mm}$., width

Molar 3, length

$13 \mathrm{~mm}$., width

$6 \mathrm{~mm}$.

$6 \mathrm{~mm}$.

Height of mandible under premolar 4

$7 \mathrm{~mm}$.

$30 \mathrm{~mm}$.

Notogale gen. nov.

This genus is proposed for the species designated ? Pharsophorus mitis by Ameghino (should probably include ? Pharsophorus temis which however never having been figured and not found in our collection I cannot definitely place). While the upper teeth have the same general character as Pharsophorus, they are much more compressed and trenchant. Upper molar 2 is similar to that of Pharasophorus in having the protocone reduced, and the metacone represented by a long sloping ridge. The last molar is also similar in having the antero-external style, the developed paracone, but the protocone is much less developed, appearing only as a ridge. In the lower teeth, however, there is a marked difference, in that the metaconid is lacking on molars, while the talonid is developed into a small basin with a single cusp on the posterior margin. This genus seems to be closest to the Santa Cruz genus Cladosictis.

\section{Notogale mitis Ameghino}

? Pharsophorus mitis, 1897, Bol. Inst. Geog. Argen., t. I 8, p. 504 .

Ameghino briefly describes, without a figure, a species in which premolar 4 and molar 3 together measure $14 \mathrm{~mm}$.

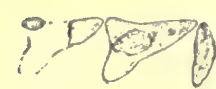

Fig. I42. Upper molars 2 to $4^{- \text {nat }}$ ural size. the same. There is also a fragment of the upper jaw with

I have assigned to this two specimens, the one with pm. 2 incomplete, pm. 3 complete, and m. 2 also complete. These teeth measure the same as Ameghino's and I think are molars 2 and 3 , though imperfect. From these it appears 
that we have to do with an animal not only smaller than the preceding, but on much slenderer lines. The following are the measurements of the two specimens.

\section{SPECIMEN 3117}

Upper dentition, molar 2, length $8 \mathrm{~mm}$., width $6 \mathrm{~mm}$. Upper dentition, molar 3 , length

SPECIMEN 3060

Lower dentition, premolar 3 , length Lower dentition, molar 2, length
$6 \mathrm{~mm}$., width

7 mm., width
$2.5 \mathrm{~mm}$.

4 กแก.

m 2

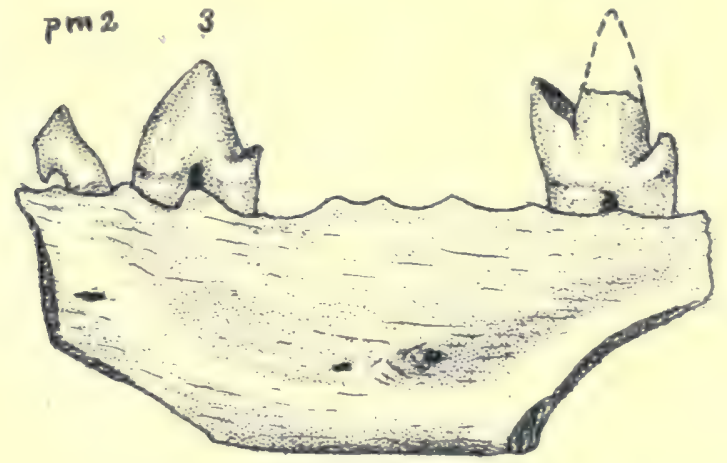

Fig. I43. Left mandible - natural size.

\section{Notogale tenuis Ameghino}

? Pharsophorus tenuis Amegh., I 897, Bol. Inst. Geog., Argen., t. 18, p. 504.

This species was founded by. Imeyhino on a single lower premolar 3 which is $3 \mathrm{~mm}$. in length. No further descrip)tion is given and no figure.

\section{Proborhyaena Ameghino}

Proborhyaena Amegh., 1897, Bol. Inst. Cieog. Argen., t. 18, p. 50 r.

The genus is founded on a large lower jaw carrying the canine and premolars 3 and $t$ and roots or alveoli for the other teeth. It is the largest carnivor recorded from Patagonia, and as large as a small bear. It is not possible 
to place its exact relationships, for the most essential teeth are wanting, but it is certainly a distinct genus as indicated by the reduced size of premolar 4 and the plump (haracter of the teeth.

\section{Proborhyaena gigantea Ameghino}

P. gigantea Amegh., 1897, Bol. Inst. Geog. Argen., t. 18, p. 50 r.

We found no specimens of this great carnivor, so I am reproducing Ameghino's figure and measurements. The

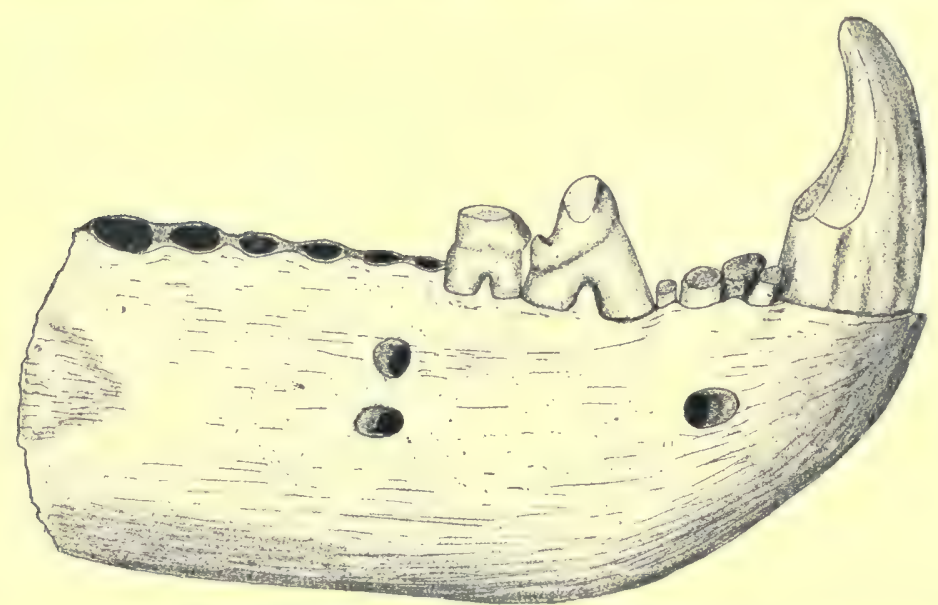

Fig. 144. Right mandible $-1 / 2$ natural size, after Ameghino.

heavy canine is channcled on the sides and much worn on the posterior face. P'remolar 3 is a plump tooth, its crown consisting mostly of a single median cusp, but with a small heel behind, and, strikingly enough, premolar 4 is a smaller and simpler tooth with a single cusp.

\section{Measurements}

Lower dentition, canine, antero-posterior diameter Lower dentition, canine, transverse diameter $30 \mathrm{~mm}$. Lower dentition, premolar I to molar 3 Lower dentition, height of mandible under pm. 4 


\section{Proborhyaena antiqua Ameghino}

? Burhyaena antiqua Amegh., 1895, Bul. Inst. Geog. Argen., 1. 15, p. 655. I'roborhyaena antiugua Amegh., 1897, Bul. Inst. Geog. Argen., t. I8, p. 502.

This species is known only hy a single canine $100 \mathrm{~mm}$. long, of which but $15 \mathrm{~mm}$. belongs to the crown. Its antero-posterior diameter is $1+\mathrm{mm}$, the transverse $12 \mathrm{~mm}$. It seems to me very doubtful whether this is a valid species.

\section{Caenolestidae}

This family, based on the living genus Caenolestes, is represented in 'Tertiary times in I'atagonia ly three subdivisions, Palueothentinae, Gurzoninae, and Abderitinae. While diprotolonts, as far as known, the family is in strong contrast to the Australian diprotodonts in that there is no sign of syndactylism in the pes. The American forms are characterized by four subequal upper incisors, a normal canine, the first three premolars vestigal, while the fourth is either normal or enlarged into a sectorial tooth. 'The three molars are progressively smaller from the front back. The first lower incisor is greatly enlarged and procumbrent, the remaining incisors, the canine, and the anterior premolars being vestigal though usually present. Premolar 4 is enlarged and sectorial in most genera, and the molars as in the upper jaw progressively smaller.

For the practical purpuses of this paper the subfamilies are distinguished as follows:

Caenolestinae, lower pm. 4 not developed into a sectorial tooth.

Palaeothentinae, lower pm. $t$ is developed into a sectorial tooth.

Abderitinae, lower pm. 4 is developed into a sectorial tooth and striated.

\section{Palaeothentinae Sinclair. \\ (=Epanorthidae Ameghino)}

This group or subfamily was established to hold several genera of tiny marsupials with the dental formula $\begin{aligned} & 3+43 \\ & +12-3\end{aligned}$ the lower fourth premolar enlarged into a sectorial tooth; 
and the molars small and buno-lophodont. From the 1)eseado beds but one genus of this suldivision has been found, Palaeothentes, designated by Ameghino first Epanorthus, then later Palaepanorthus, but as I can see no reason for distinguishing the I leseado species of the genus from those of the Santa Cruz, I have retained the name Palaeothentes.

'The genera of this subfamily are distinguished as follows:

\section{LOWER Third P'REMOlar}

Palaeothentes 2-rooted, fairly large, equals pm. 4 in height.

Pilchenia 2-rooted, moderate size nearly equals pm. 4 in height.

Callomenus 2-rooted, small size much lower than pm. 4 .

Decastris, r-rooted, vestigal.

\section{Palaeothentes (Moreno) Ameghino}

Palaeothentes Moreno, I882, Patagonia, Resto de un Continente hoy submergido, p. 22, (nomen nudum).

Palaeothentes (Moreno) Ameghino, 1887, Enum. Sist. Espesies Mamif. Fos, Patagonia, p. 5 .

Epanorthus Ameghino, I 889, Act. Acad. Nac. Cienc. Cordoba, t. 6, p. 27 I. Epanorthus Amegh., 1897, Bol. Inst. Geog. Argen., t. 18, p. 500. (nudum). Palaepanorthus Amegh., I901, Anal. Soc. Cienc. Argen., t. 51, p. 77, (nomen). Palaepanorthus Amegh., 1902, Bol. Acad. Nac. Cienc. Cordoba, t. 18, p. 123. Palaepanorthus Amegh., 1903, Anal. Mus. Nac. Buenos Aires, t. 9, (ser. 3, t. 2) 1). 239 .

Among the Santa Cruz specimens, this genus is distinguished by having in the lower jaw the large first incisor, then five vestigal teeth, followed by a two-rooted, though somewhat reduced, third premolar, next the enlarged fourth premolar, making the sectorial tooth, and lastly three buno-lophodont molars.

There is considerable confusion as to the use of the generic name. Moreno designated the first specimen, Palaeothentes, without a description; then Amoghino used this term describing the species; later Ameghino thinking that the name Palaeothentes was the same as Palaeothentis proposed the name, Epanorthus, using this for the first description 
of the Deseado species. Later, however, he changerl thifor Palacpanothus. As I can see no generie differences between the I)eseado and Santa ( ruy species. I shall follow Sinclair in using the generis term Palaeothentes.

\section{Palaeothentes chubutensis Ameghin(,}

Epanorthus chubutensis Amegh., I 897, Bol. Inst. Geog. Argen., t. I8, p. 500.

Palaepanorthus chubutensis Amegh., 1901, Anal. Soc. (ienc. Argen., 1. 5I, 1) 77.

Palaepanorthus chubutensis Anegh., 1902, Bol. Acad. Nac. Cienc. Corduba, t. 18, p. 123.

Palaepanorthus chubutensis Amegh., I903, Anal. Mus. Nac. B. A., t. 9 (ser. 3 , t. 2) p. 239.

The species is founded on a tiny mandible with premolar 3-molar 3 , on which the third premolar, while reduced,

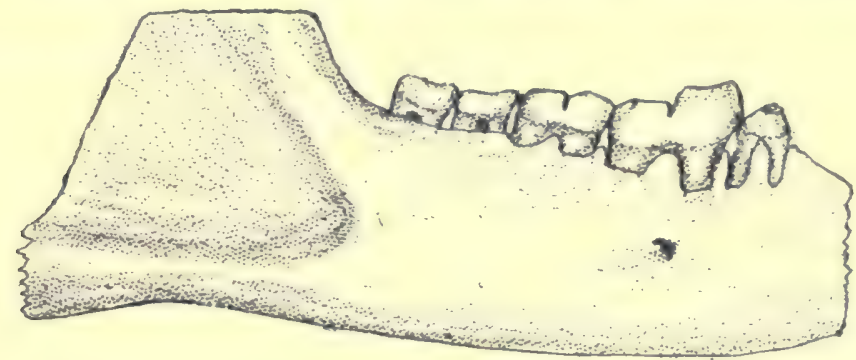

Fig. 145. Right mandible-2 times natural size, after Ameghino.

has two roots and reaches the height of the fourth premolar, being in about the same stage of development as the Santa Cruz species. As we found no specimens of this species I reproduce Ameghino's figure and measurements.

L.ower dentition, premolar 3 to molar 3

Lower dentition, height under premolar 4

19) $\mathrm{mm}$.

$12 \mathrm{~mm}$.

\section{Pilchenia Ameghino}

Pilchenia Ameghino, 1903, Anal. Mus. Nac. Buenos Aires, ser. 3, t. 2, p. 128. Pilchenia Ameghino, 1904, Anal. Soc. Cienc. Rep. Argen., t. 58, p. 259.

This genus was founded on a single lower molar which, in the light of the specimen we found, I take to be the third 
or last. (Our specimen shows pm. 3 and 4 and the three molars. The third premolar is a small two-rooted tooth with a simple crown and no heel. Premolar 4 is an enlarged sectorial tooth, the anterior part consisting of two cuspe, closely set near the median line, with an incipient cusp on the inner face of the large anterior cusp). The posterior part of this tooth is arranged as a typical talonid, with one internal and two external cusps on the margin of a shallow inclosed basin. On the rear of the tooth is a small crescent-like cingulum, which occurs in the same place on molars $I$ and 2, but is lacking on molar 3. This is a characteristic feature of the genus. ()n the anterior part of the molars is developed a sort of trigonid of small size, and the cusps are indistinct. The posterior portion of each molar is a large talonid with a shallow basin surrounded by a low wall on which are three tiny cups (the entoconid, hypoconid, and hypoconulid).

\section{Pilchenia lucina Ameghino}

P. lucina Amegh., I903, Anal. Mus. Nac. B. A., ser. 3, t. 2, p. I28.

P. lucina Amegh., 1904, Anal. Soc. Cienc. Rep. Argen., t. 58, p. 259.

In the Deseado beds, on the Chico del Chubut River, west of Puerto Visser, we found a single specimen of this

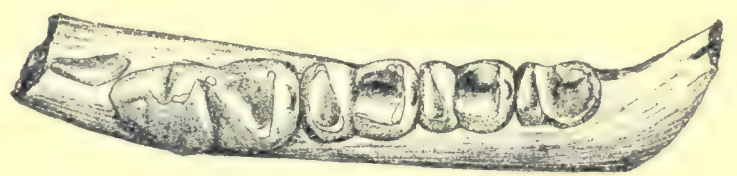

Fig. 146. Left mandible with premolar 3 to molar $4-4$ times natural size.

species which agrees with the single footh ligured hy Ameghino as the type, and which $I$ interpret as molar 3. The description is given under the genus, the measurements are as follows: 
SPECIMEN No. 3110

Lower dentition, distance from premolar 3 to molar 3

$14 \mathrm{~mm}$.

Lower dentition, premolar 3 , length

$2 \mathrm{~mm}$., width

$.75 \mathrm{~mm}$.

Lower dentition, premolar 4 , length

$5 \mathrm{~mm}$., width

$2.5 \mathrm{~mm}$.

Lower dentition, molar $\mathbf{I}$, length

$3 \mathrm{~mm}$., width

$2 \mathrm{~mm}$.

Lower dentition, molar 2, length

$2.5 \mathrm{~mm}$., wirth

$2 \mathrm{~mm}$.

Lower dentition, molar 3 , length

Lower dentition, height under pm. 4

$2 \mathrm{~mm}$., width

1. $75 \mathrm{~mm}$.

\section{Callomenus Ameghino}

Callomenus Anegh., I89I, Neuvos Restos Mamif. Fus. Patagnnia Austral, p. 20.

Callomenus Sindair, I90I-6 Princeton Patag. Experlitions, vol. 4, p. 4.34.

This genus has not heen previnusly reported from the I)eseado beds, but we found a tiny lower jaw with three teeth to represent it. The genus is distinguished by premolar 3 being two-rooted, but so small as not to attain the height of premolar 4 .

Callomenus praecursor sp. nov.

The type is specimen No. 3020, a fragmentary mandihle with premolars 3 and $t$ and molar $I$ in place. P'm. 3 is

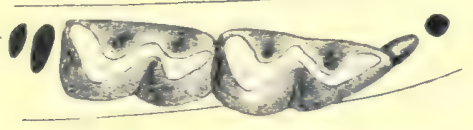

Fig. 147. Left mandible with premolat 3 to molar $2-4$ times natural size.

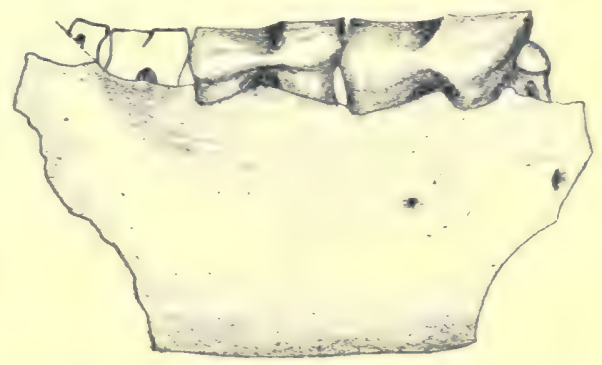

Fig. 148 . Left mandible internal side \& times natural size.

two-rooted, but so small as to he entirdy orershadowed hy the succeeding $\mathrm{pm}$. 4 , hardly reaching a half the height of that tooth. On the last premolar and the first molar, the cusps are arranged in a trigonid in front and a talonicl behind, the cusps being joined by thick ridges, making two connecting crescents. 


\section{Measurements, Specimen 3020}

Lower dentition, premolar 3 , length lower dentition, premolar 4 , length Lower dentition, molar $\mathbf{I}$, length Lower dentition, height under pm. 4
I $\mathrm{mm}$.
$5 \mathrm{~mm}$., width
$2 \mathrm{~mm}$.
$4 \mathrm{~mm}$., width
$6.5 \mathrm{~mm}$.
$2 \mathrm{~mm}$.

\section{Caenolestinae}

The subfamily is distinguished by the formula $\begin{gathered}4 \\ 4\end{gathered}$ pm. 4 not being enlarged, and the lower molars being tuberculo-sectorial. In the Insearlo formation this group is only represented hy a single species, based on a single tooth found by Ameghino.

\section{Pseudhalmarhiphus guaraniticus Ameghino}

P. guaraniticus Amegh., 1903, Anal. Mus. Nac. Bucnos Aires, ser. 3, t. 2, p. 83.

Based on a single tooth, similar to those found in the Santa Cruz.

\section{Abderitinae}

The subfamily is distinguished by the formula $\frac{? ? ? ? \text { ? }}{4 I 23}$, the fourth premolar being enlarged into a sectorial tooth on the sides of which are vertical striae. The molars are buno-lophodont. The Deseado has yielded only a tiny form, designated Parabderites, which differs from the Santa Cruz genus Abderiles in pm. 4, the same shape, by with few to no striae on its sides.

\section{Parabderites minusculus Ameghino}

P. minusculus Amegh., 1902, Bol. Acad. Nac. Cienc. Cordoba, t. 17, p. 43.

The species as described by Ameghino is based on a lower jaw with pm. 3 to $\mathrm{m} .3$. The specific character is the lack of striae on pm. 4. No figure is given but the following measurements indicate the size. 


\section{CHAPTER XVI}

\section{BIRDS}

In THE Deseato beds, birds occur in small numbers, Ameghino having described four species. The remains are generally found as isolated bones, and it is hard to associate the separate finds one with another. Beside this there are very few hirds of the early 'Tertiary so known, as to make separate bones indicate the family or gencric relationships.

In the overlying Patagonian beds, a consislerable number of species have been found, mostly of penguin-like birds, the various genera and species being based on the tarsometatarsus. On the upper surface of the I)esearlo, we found several bones of this penguin-like type, hut in all cases they were washer out, so that I have considered them as having come from the Patagonian.

However, we found eight specimens of hirels in plare in the Deseado, most of which are clearly land hirds and belong to genera which are closely related to genera of the Santa (ruz, especially the two genera Phororharus and Pelecyornis, and of sizes equal to the largest representatives of the two genera.

\section{Phororhacus Ameghino}

Phororhacus Amegh., 1887, Bol. Mus. I.a Plata, t. I, p. 24.

Phororhacus Amegh., 1889, Act. Acad. Nac. Cienc. Cordoha, t. VI, p. 659. Phororhacus Amegh., I 895, Bol. Inst. Geog. Argen., t. 15, p. Io of separate.

This is a group of large land birds, comparable in size to the great moas of New Zealand which apparently arose, flourished, and died out in South America. In the Santa Cruz they were abundant, the hest known form being P. inflatus, a bird some six feet high; while the largest, P. longissimus, 
had a head nearly twice as long and limb bones half again as large as this species; so that it represented a bird nine to ten feet high. Previously but one specimen of this type, a part of a mandible, has been found in the Descado beds. We were fortunate enough to find the greater part of a femur, indicating a lirrl equal to the largest of those in the Santa Cruz. There are also toe bones of Phororachus of a size about the same as $P$. inflatus.

A host of names, generic and specific, have been given to the individual bones of the hirds of this type, but Ameghino, in studying the lirds of the Santa Cruz, brought them all together under the single genus Phororhacus. (See Bol. Inst. Geog. Argen., I 895, t. I 5.) Referring to the single bone in the Ineseado, however, he gave it a new generic name Physornis, which differs from Phororhacus only in the lower jaw being more convex, but should stand until better material has been found to establish whether it differs enough to be entitled to generic independence.

\section{Physornis fortis Ameghino.}

P. fortis Amegh., 1895, Bol. Inst. Geog. Argen., t. 15, p. 576.

Inder this specific name Ameghino describes a part of the lower jaw I $50 \mathrm{~mm}$. long which he says equals in size Phororhacus longissimus, and differs only in the greater convexity of the mandible. (Our specimen is a femur, apparently of the same bird, being of the type of Phororhacus and about the size of P. longissimus; so I have placed it in this species.

This femur is of large size, moderate length, and has a shaft subcylindrical in section. The distal end is expanded and the condyles are flattened, the inner one being the wider, the outer condyle being narrower and the external margin projecting to make a high ridge. The pit on the posterior side of the shaft just above the condyles is unusually deep and of large size. On the anterior side there extends from wither condyle a low marginal ridge which soon fades into 


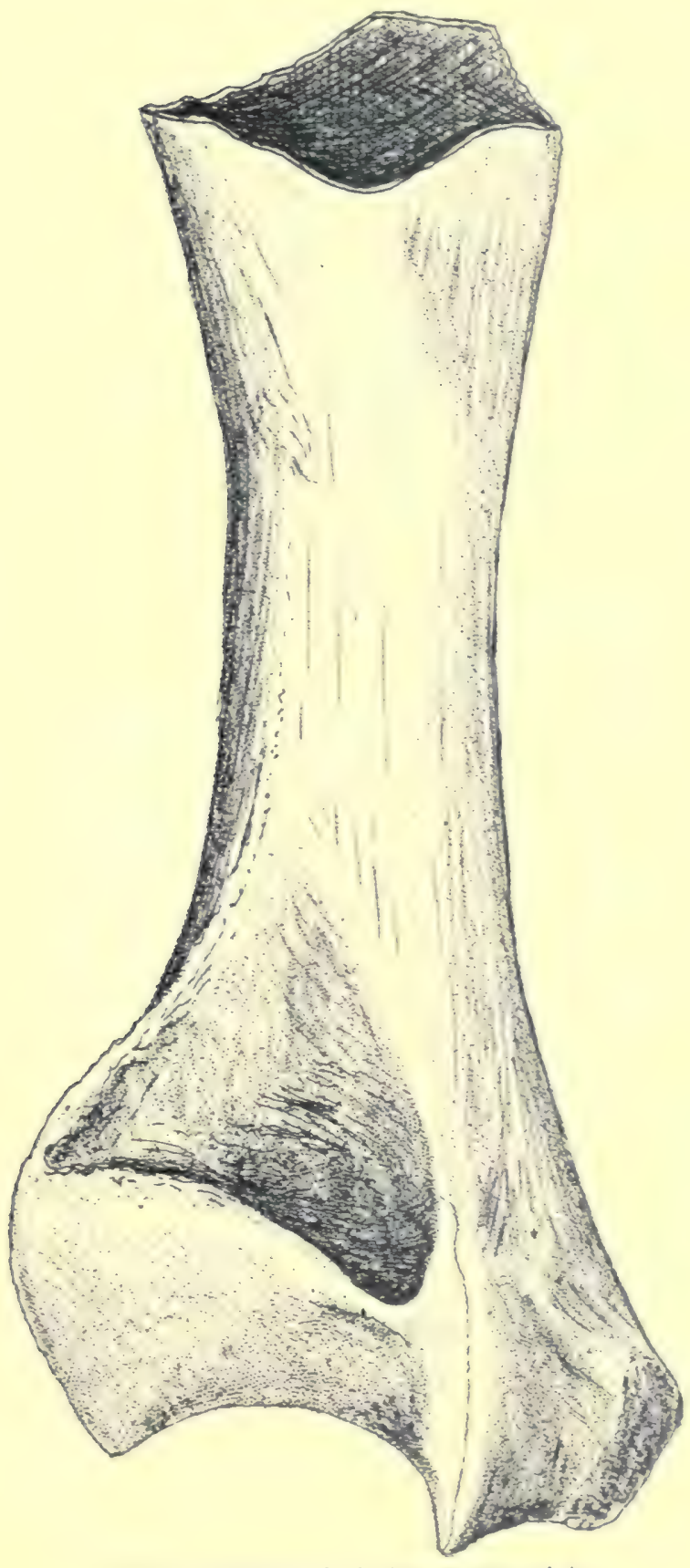

Fig. I49. Right iemur, back view-: 2 natural size. 
the contour of the shaft. Between these ridges there is a wide shallow furrow which also loses itself above in the convex surface of the shaft.

\section{Measurements}

Femur, least diam. of the shaft

Femur, diameter across the condules

$58 \mathrm{~mm}$. $148 \mathrm{~mm}$.

\section{Physornis sp.?}

Two phalanges of a size too small to belong to the above species represent a second smaller bircl of this type, about equal in size to Phororhacus infiatus. I give a figure of one toe but would wait for more typical material before establishing a species.
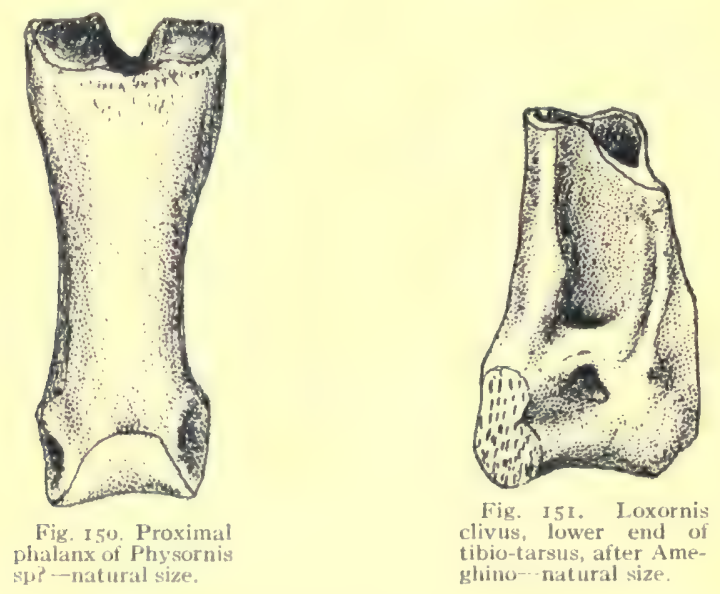

\section{Loxornis Ameghino}

Loxornis Amegh., 1895, Bol. Inst. Geog. Argen., t. 15, p. 595.

Another groul) of bones, which we found with considerable frepuency, have the same features as Pelecyormis of the Santa (ruz. Ameghino has described but the lower (n) of a tibio-tarsus which can be associated with these bones and to it gave the name Loxornis. I can not find 
much variation from Pelecyormis except that the coracoid is considerably shorter and wider, and there is a slight variation in the lower end of the tibio-tarsus. These then are the bases of the generic name.

\section{Loxornis clivus Ameghino}

L. clivus Amegh., 1895, Bol. Inst. Geog. Argen., t. 15, p. 595.

Under this name Ameghino has described the lower end of a tibio-tarsus, a figure of which I reproduce here. This is of a size to complete the tibio-tarsus which we found, lacking the lower end, and agrees in size with the wther

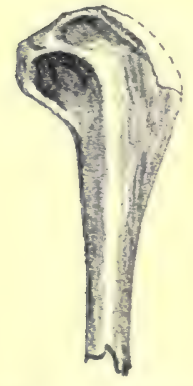

Fig. I52. Humerus$1 / 2$ natural size.

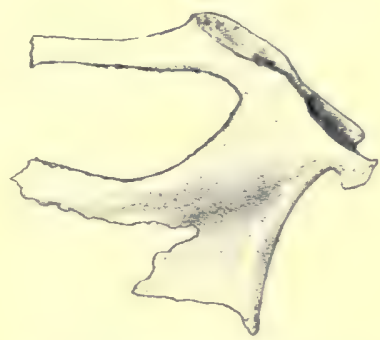

Fig. I53. Sternum, thin parts lacking-1/2 natural size.

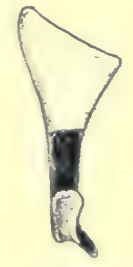

Fig. I54. CoracoidI/ 2 natural size.

bones which we found, so that I shall describe my material under this name. The species is in size comparable to Pelecyornis tubulatus with which it agrees closely:

IVe found the upper four-fifths of a tibio-tarsus, associated with part of the fibula, the sternum, the humerus, and the coracoid; a second specimen consisting of a complete tarso-metatarsus, and fragments of the pelvis, vertebrat and wing bones; a third specimen consisting of part of the tibio-tarsus, and various fragments; a fourth consisting of a femur, and lastly two toes; all evidently representing one species, which in most respects is almost identical with Pelecyornis tubulatus. These all (ame from the (hico del Chubut, west of Puerto Visser. 
The humerus has a large head but is considerably flattened at the proximal end. The internal side is deeply excavated, the shaft is slender and light as though the wing were quite reduced, though not so much as in Pelecyornis and not nearly as much as in Phororhacus.

The sternum had a moderate keel but both this and body of the bone are very thin, so much so, that in my specimen, much is broken away, giving the figure the appearance of the bone being fenestrated, which was not the case. In general the sternum is similar to Pelecyornis.

The coracoid is a decidedly stout bone, with a wide distal end for articulation of the sternum. The proximal end has a long articular facet for the scapula. This bone is heavier than the corresponding one in Pelecyornis.

The femur has a small rounded head on a short neck, the articular surface spreading over the entire proximal end of the bone. Thus the trochanter is abbreviated and does not rise above the top of the head. The shaft is of considerable length and fairly heavy.

The tibio-tarsus has a wide flaring end to receive the articulation of the femur. The bone is very long as in Pelecyornis. On the external side is a long ridge along which the fibula was attached by cartilage or by ligaments, but was not fused to the tibio-tarsus. The shaft is approximately cylindrical in section and fairly heary. 'The distal end is missing, but if I have associated correctly the specimen figured by Ameghino, the condyles are flattened, the inner being the flatter, and the outer rising in a narrow margin.

Figure I 57 shows a fibula which would have occupied the position indicated along the side of the tibio-tarsus and corresponds entirely with the same bone in Pelecyornis.

The tarso-metatarsus is long and slender, almost exactly the counterpart of the same bone in Pelecyormis. The bone has a triangular upper end, with two shallow articular 
concarities, separated by a median spine. The shaft is rectangular in cross section, has a shallow depresion on the anterior face extending from the upper end to below the middle of the shaft; while on the posterior surface is a

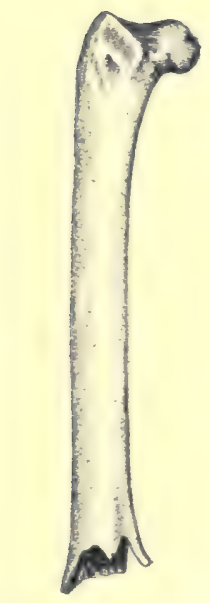

Fig. I55. Femur-I $/ 2$ natural size.

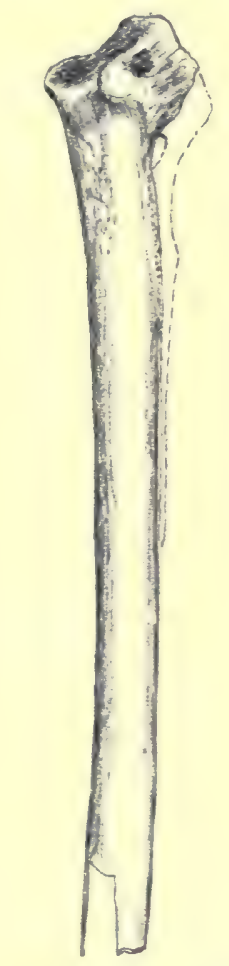

Fig. 156. Tibio-tarsus $-\mathrm{I} / 2$ natural size; fibula indicated in outline.

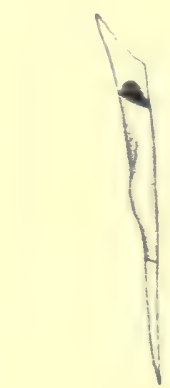

Fig. 157. Fibula $\rightarrow 1 / 2$ natural size; outline from impression in matrix.

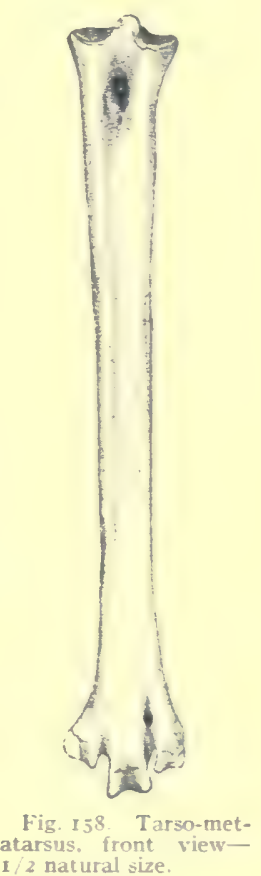

similar furrow, which is however bounded by a higher ridge on the external margin. The distal articular condyles are almost bilaterally symmetrical, the middle onc being about half again as large as the two lateral ones. Just alove the cleft between the condrles for digits III and IV there is a moderate sized perforation. 
Of the phalanges, I have two unguals which are narrow curved claws. These were not found in association with any of the foregoing hones, but correspond in size and general character to those of Pelecyornis, and so I consider them as belonging to this genus and species.

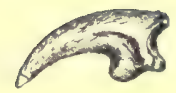

Fig. 159. Ungual phalan $x-1 / 2$ natural size.

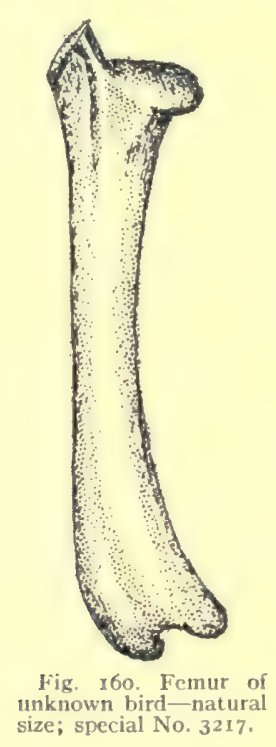

Ameghino has suggested that the genus was related to ducks, but with the more complete material it scems, in general build, much closer to the aberrant land birds of the Tertiary of South America, Pelecyornis and Phororhacus; and I am not in position to say what their derivation may have been.

Beside the above species there are several more or less complete but isolated bones indicating the presence of other and much smaller birds. I figure such a femur natural size. 




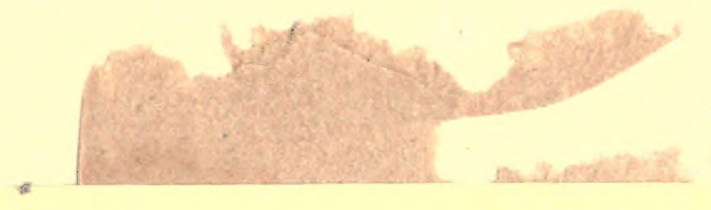

QE Loomis, Frederic Brewster

752 The Deseado formation of

P3L6 Patagonia

P\&ASci.

\author{
PLEASE DO NOT REMOVE \\ CARDS OR SLIPS FROM THIS POCKET
}

UNIVERSITY OF TORONTO LIBRARY 
